\title{
"ESTUDO DO PROJETO E DA CONSTRUÇÃO DE EDIFÍCIOS DE ANDARES MÚLTIPLOS COM ESTRUTURAS DE AÇO"
}

Eng. JOSÉ JAIRO DE SÁLES

Tese apresentada à Escola de Engenharia de São Carlos, da Universidade de São Paulo, como parte dos requisitos para obtenção do Título de Doutor em Engenharia de Estruturas.

ORIENTADOR: Prof. Dr. Roberto L. A. Barbato

São Carlos

1995 


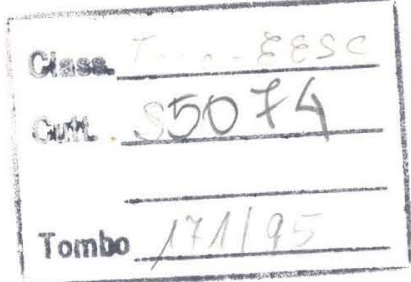

st 742958

José Jairo de Sáles

D275e Estudo do Projeto e da Construção de Edifícios de Andares Múltiplos com Estruturas de Aço. José Jairo de Sáles - São Carlos, 1995.

$257 p$.

Tese (Doutorado)-Escola de Engenharia de São Carlos-Universidade de São Paulo, 1995.

Orientador: Prof.Dr. Roberto L. A. Barbato

1. Aço . Edificios Andares Múltiplos. I. Título. 
à memória de LUCIANA

a mais querida afilhada

à minha esposa Ursula e aos meus filhos Ana e Clóvis que nunca reclamaram por eu estar sempre ocupado 
.... aos que fizeram da COBRAPI

a materialização do sonho tecnológico do terceiro mundo, quando absorveu, dominou e desenvolveu tecnologia própria para o setor siderúrgico, em especial ao Preu, Lippi, Álvaro, Valiante, Pedro, Stella, Jovelino, Chico, Petrúcio, Torrico, Arthur, Dario, Alberto, Benedito, Miltom, e,..........muito especialmente ao Duílio, que tanto me ensinou.

Não esquecendo:

Carlos Vargas João Batista Santoro José de Moura Villas Boas Rui Martins

Ter trabalhado com vocês foi mais que uma honra, foi um privilégio. 


\section{AGRADECIMENTOS}

Ao Prof. Roberto Barbato, que teve ânimo para orientar e incentivar mas, principalmente, por ter achado durante todo o tempo que a conclusão deste trabalho era possivel.

Aos Professores da área que sempre estavam dispostos a ouvir, discutir e a contribuir com este trabalho, em especial ao Maximiliano Malite e ao Roberto M. Gonçalves, que inclusive se sobrecarregaram para que eu pudesse terminá-lo.

Aos funcionários do Departamento de Engenharia de Estruturas da Escola de Engenharia de São Carlos, especialmente ao Sr. Antonio Valdair Carneiro pela digitação, ao Sr. Francisco Carlos Guete de Brito pelo esmêro e paciente realização dos gráficos e figuras, e à Sra. Maria Nadir Minatel por sua colaboração na pesquisa bibliográfica. 


\section{SUMÁRIO}

LISTA DE FIGURAS

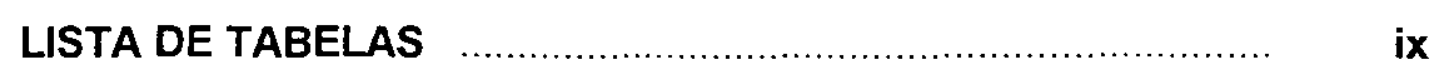

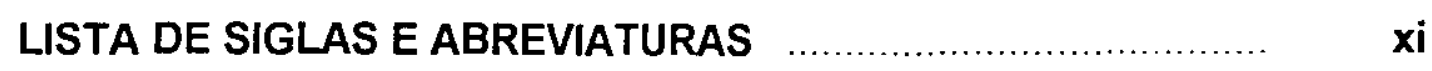

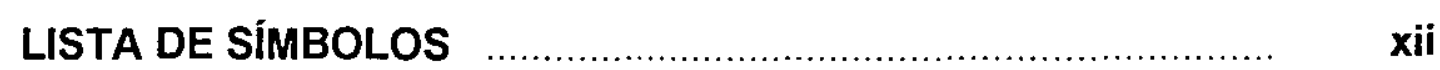

RESUMO

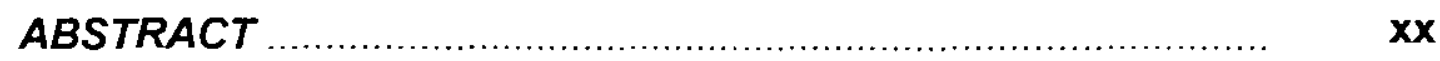

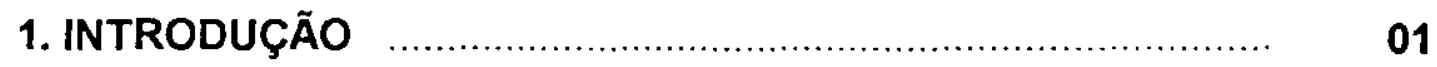

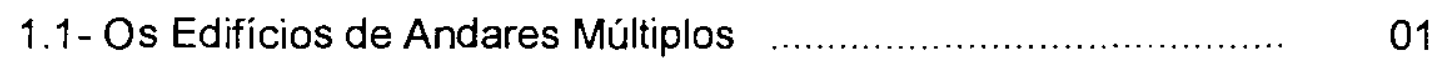

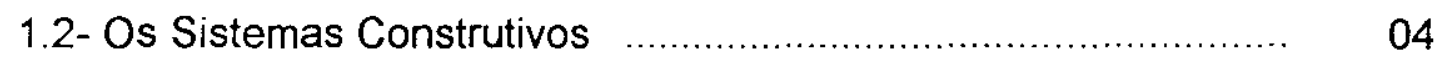

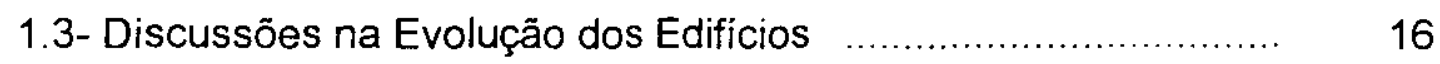

1.4- Os Edifícios de Aço no Brasil ........................................ 20

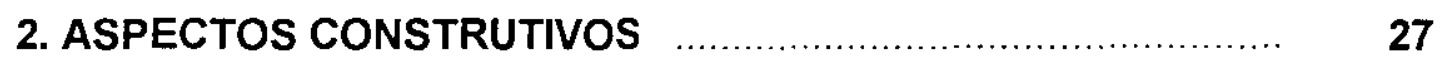

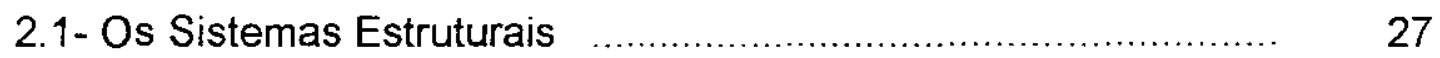

2.2- A Racionalização nas Estruturas de Aço ….......................... 35

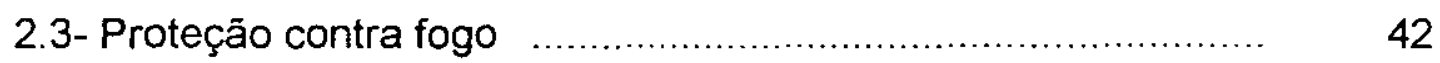

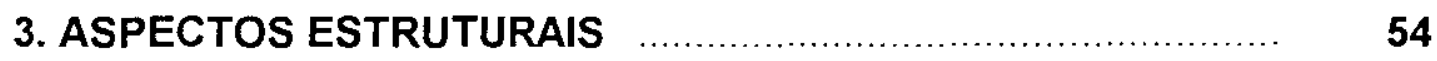

3.1- Ações Permanentes .................................................... 54

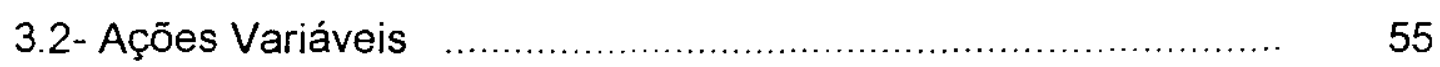

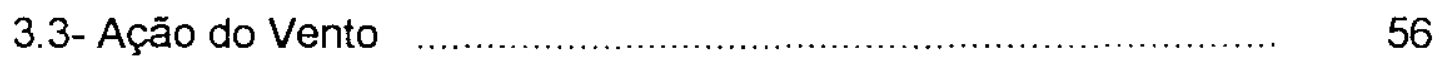

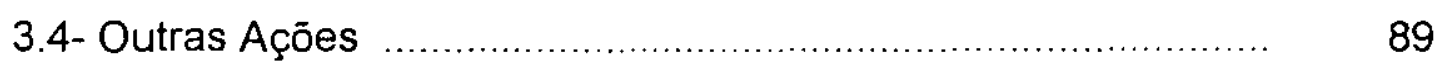

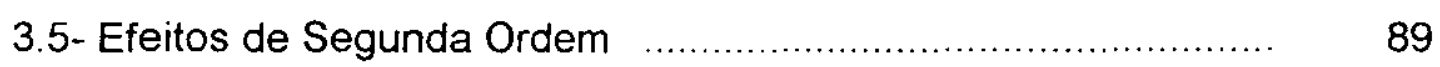

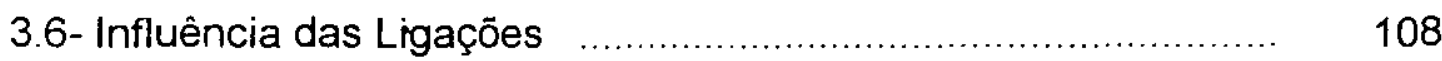

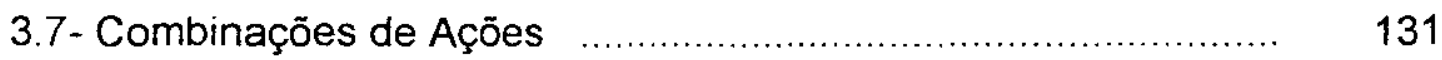


4.1- Origem dos Sistemas

4.2- Sistemas de Pisos …….................................................. 135

4.3- Edifício Exemplo ............................................................ 146

4.3.1- Vigas dos Pisos ...................................................... 154

4.3.2- Vigas da Cobertura …................................................... 162

4.3.2- Colunas .................................................................... 163

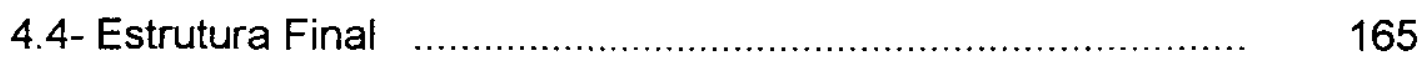

4.5- Efeito de Segunda Ordem ................................................. 187

4.6- Procedimento Alternativo …….............................................. 201

4.7- Efeito Dinâmico do Vento ................................................... 206

4.7.1- Método Simplificado .................................................... 207

4.7.2- Método Discreto ...................................................... 209

4.7.3- Verificaçāo das Solicitaçōes ......................................... 212

5- ANÁLISE COMPARATIVA

$\begin{array}{ll} & 217\end{array}$

5.1- Os Núcleos de Serviço .......................................................... 222

5.2- Sistemas Treliçados …........................................................ 227

5.3- Sistemas Tubulares …................................................. 230

5.4- Critérios para Otimização _................................................... 234

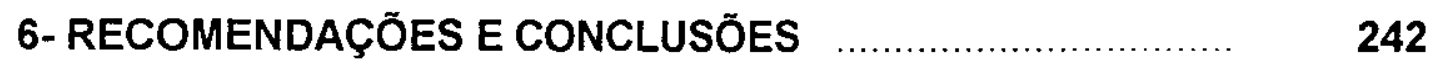

6.1- Sobre o Emprego de Estruturas de Aço ............................... 242

6.2- Sobre os Aspectos Estruturas ……....................................... 243

6.3- Sobre a Análise Comparativa ........................................... 250

6.4- Temas para Continuação da Pesquisa …….......................... 253

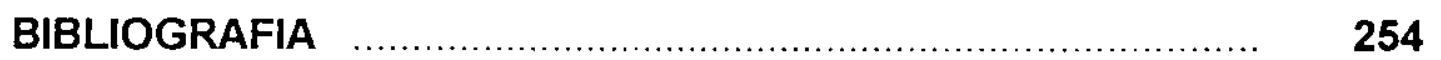




\section{LISTA DE FIGURAS}

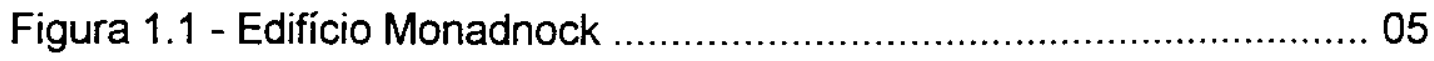

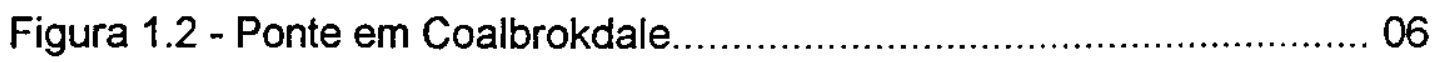

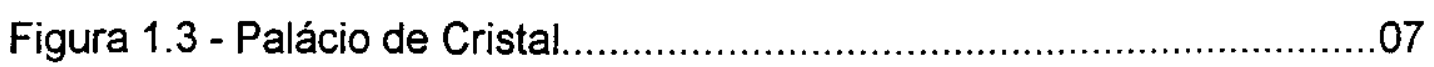

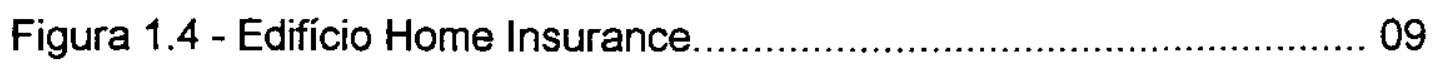

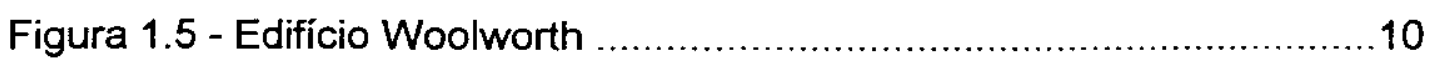

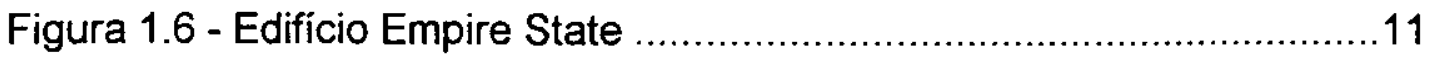

Figura 1.7 - Edifício Lever House ........................................................ 14

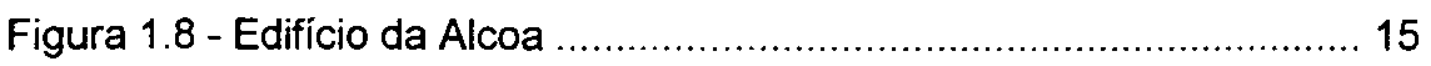

Figura 2.1 - Fábrica de Chocolate sobre o rio Marne ………................... 29

Figura 2.2 - Edifício Civic Center ...................................................... 32

Figura 2.3 - Edifícios John Hancock e World Trade Center ....................... 33

Figura 2.4 - Edifício da Sears ........................................................ 34

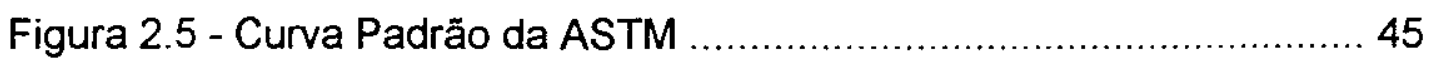

Figura 2.6 - Variação da Tensão de Escoamento ..................................... 46

Figura 2.7 - Variação do Módulo de Elasticidade Longitudinal .................. 46

Figura 2.8 - Resistência ao Fogo em Função do Fator de Forma ............... 51

Figura 3.1 - Consumo de Aço em Função da Altura .................................. 55

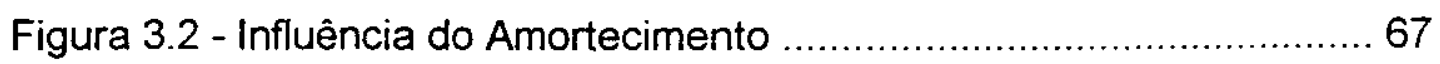

Figura 3.3 - Fases entre Deslocamento/Nelocidade/Aceleração ............... 69

Figura 3.4 - Situações Amortecidas e em Ressonância .............................. 71

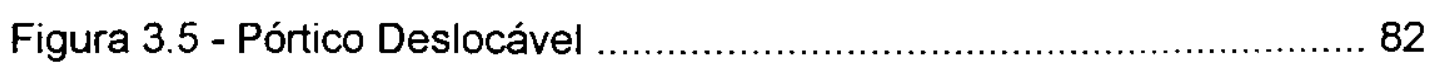

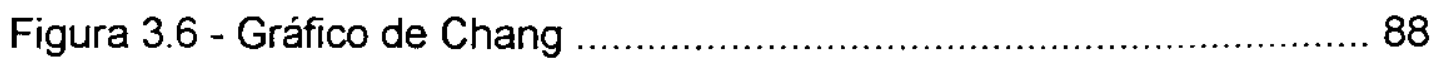

Figura 3.7 - Viga-coluna com ação distribuída uniformemente .................. 91

Figura 3.8 - Viga-coluna com Momento Aplicado ..................................... 94

Figura 3.9 - Pilar sob Ações Combinadas.............................................. 97

Figura 3.10 - Pilar Genérico em Análise não Linear ................................ 99

Figura 3.11 - Estrutura Deslocável ................................................... 103

Figura 3.12 - Estrutura Indeslocável .................................................... 104

Figura 3.13 - Ligações Rígidas, ou do Tipo 1 (Engastes ) ..................... 109 
Figura 3.14 - Ligaçōes Flexiveis, ou do Tipo 3 ( Rótulas ) ....................... 109

Figura 3.15 - Ligações Semi-Rígidas, ou do Tipo 2 ............................. 110

Figura 3.16 - Solução Clássica de Viga Bi-engastada ........................... 111

Figura 3.17 - Comportamento das Ligações ( LRFD) ............................. 112

Figura 3.18 - Modelo Simplificado do Comportamento das Ligações ...... 113

Figura 3.19 - Efeito de Alavanca em uma Ligação .................................. 114

Figura 3.20 - Giro em Ligação Flexível ............................................ 119

Figura 3.21 - Gráfico de Rigidez/Deslocamento .................................... 124

Figura 3.22 - Ligação em Viga Mista ................................................ 125

Figura 3.23 - Concentração de Tensōes nas Cantoneiras de Ligação ... 130

Figura 4.1 - Correção da Frequência Natural das Vigas .......................... 143

Figura 4.2 - Gráfico de Conforto Humano ............................................. 146

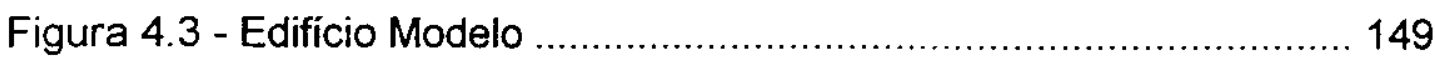

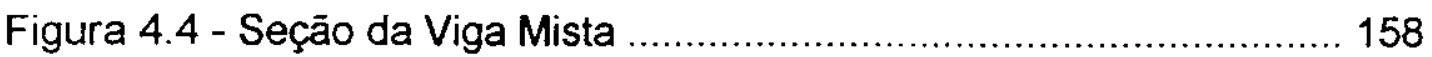

Figura 4.5 - Deslocamentos de Primeira e de Segunda Ordem .............. 213

Figura 5.1 - Pavimento Tipo - Aporticado .......................................... 215

Figura 5.2 - Núcleo Metálico Aporticado ................................................ 218

Figura 5.3 - Pavimento Tipo - Aporticado - Núcleo Metálico Aporticado .. 219

Figura 5.4 - Núcleo Metálico Treliçado .............................................. 220

Figura 5.5 - Pavimento Tipo - Núcleo Metálico Aporticado ..................... 221

Figura 5.6 - Pavimento Tipo - Paredes Resistentes .............................. 222

Figura 5.7 - Pavimento Tipo - Núcleo de Concreto ................................. 223

Figura 5.8 - Ligações Típicas Aço/Concreto ......................................... 224

Figura 5.9 - Pavimento Tipo - Núcleo Misto ....................................... 225

Figura 5.10 - Ligaçōes Típicas de Núcleo Misto ................................... 226

Figura 5.11 - Treliças Alternadas ................................................... 228

Figura 5.12 - Treliças Conjugadas ............................................... 229

Figura 5.13 - Pavimento com Treliças Horizontais .............................. 230

Figura 5.14 - Pavimento Tipo - Sistema Tubular .................................. 231

Figura 5.15 - Tubular Aporticado ........................................................ 231

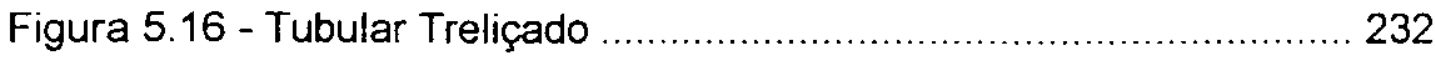

Figura 6.1 - Ligações Típicas para Vigas-Colunas ................................. 246

Figura 6.2 - Deslocamentos Horizontais dos Diversos Sistemas............. 252 


\section{LISTA DE TABELAS}

\section{Segundo Capitulo}

Tabela 01 - Período Resistente ao Fogo

\section{Terceiro Capitulo}

Tabela 02 - Variação da Frequência Natural com a Relação D/H 84

Tabela 03 - Valores de $\mathrm{Cm}_{\mathrm{m}}$ e $\mathrm{B}_{1}$ em função da Relaçăo P/P (Viga Apoiada com Ação Distribuída) 93

Tabela 04 - Valores de $\mathrm{Cm}_{\text {e }} \mathrm{B}_{1}$ em função da Relação $\mathrm{P} / \mathrm{P}_{\mathrm{e}}$ ( Viga Apoiada com Ação Concentrada no meio do Vão ) .... 94

Tabela 05 - Valores de $\mathrm{Cm}$ para diversas Situações de Carregamento .... 96

Tabela 06 - Deslocamentos de Primeira e de Segunda Ordem

(Estruturas Indeslocáveis ) 103

Tabela 07 - Deslocamentos de Primeira e de Segunda Ordem

(Estruturas Deslocáveis) 105

\section{Quarto Capítulo}

Tabela 08 - Ações Devidas ao Vento nos Andares ............................... 152

Tabela 09 - Solicitações nas Vigas do Pavimento Tipo .......................... 159

Tabela 10 - Solicitações nas Vigas da Cobertura .................................. 162

Tabela 11 - Iterações no Dimensionamento ............................... 172 a 177

Tabela 12 Momentos Resistentes nas Vigas dos Pisos ....................... 193

Tabela 13 - Planilhas de Cálculo do Efeito P- $\Delta$ 195 a 199

Tabela 14 - Cálculo do Efeito P- $\Delta$ pelo Procedimento Alternarivo ............204

Tabela 15 - Deslocamentos Obtidos pelos Diversos Procedimentos ...... 205

Tabela 16 - Deslocamentos Horizontais Devidos ao Efeito Dinâmico do Vento - Método Simplificado ......................................... 208

Tabela 17 - Variáveis Intermediárias para o Método Discreto ................ 210

Tabela 18 - Deslocamentos Horizontais Devidos ao Efeito Dinâmico do Vento - Método Discreto - 


\section{Quinto Capitulo}

Tabela 19 - Perfis Finais para as Colunas do Sistema Aporticado ......... 216

Tabela 20 - Perfis Finais para as Colunas do Sistema

Núcleo Metálico Aporticado .......................................... 219

Tabela 21 - Perfis Finais para as Colunas do Sistema

Núcleo Metálico Treliçado ............................................ 221

Tabela 22 - Perfis Finais para as Colunas do Sistema

Paredes Resistentes

Tabela 23 - Perfis Finais para as Colunas do Sistema

Treliças Conjugadas 229

Tabela 24 - Perfis Finais para as Colunas do Sistema

Tubular Aporticado

Tabela 205 - Perfis Finais para as Colunas do Sistema

Tubular Treliçado 233

Tabela 26 - Sistema Aporticado - Pórtico do Eixo 2

Deslocamentos por Sistema Estrutural 236

Tabela 27 - Perfis das Colunas com $\mathrm{H}=400 \mathrm{~mm}$ e suas Resistências à Compressão

Tabela 28 - Perfis das Colunas com H=700 mm e suas Resistências à Compressão

Tabela 29 - Perfis das Colunas com H=800 mm

e suas Resistências à Compressão

Tabela 30 - Perfis das Colunas com H=1140 mm

e suas Resistências à Compressão

Tabela 31 - Consumo de Aço para cada Sistema 


\section{LISTA DE SIGLAS E ABREVIATURAS}

ABNT - Associação Brasileira de Normas Técnicas

AISC - American Institute of Steel Construction

AISE - Association of Iron and Steel Engineers

AISI - American Iron and Steel Institute

ASD - Allowabe Stress Design (Manual do AISC - Tensōes Admissiveis ))

ASTM - American Society for Testing and Materials

ANSI - American National Standard Institute

AWS - American Welding Society

LRFD - Load Resistance Factor Design (Manual do AISC nos Estados

Limites)

ISO - International Standard Organization

NBR - Norma Brasileira Registrada

SSPC - Steel Structures Painting Council 


\section{LISTA DE SÍMBOLOS}

\section{LETRAS LATINAS MAIÚSCULAS}

$A=$ Coeficiente algébrico indeterminado

$A_{c}=$ Área exposta ao calor

$A_{e}=$ Área efetiva

$A_{0}=$ Área de referência

$A_{p}=$ Área de pavimento

$A_{S}=$ Área de uma seção transversal

$A_{v}=$ Área das berturas de ventilação

$B=$ Coeficiente algébrico indeterminado

$B_{1} ; B_{2}=$ Coeficientes de segunda ordem ( LRFD )

$C=(0,7 / 0,9) Q_{n}=$ Força de compressão na laje de uma viga mista

$C^{\prime}=$ Força de compressão na mesa de uma viga mista

$\mathrm{C}_{1} ; \mathrm{C}_{2} ; \mathrm{C}_{3}=$ Constantes de integração

$\mathrm{C}_{\mathrm{m}}=$ Fator de equivalência de carregamentos

$D=$ Coeficiente algébrico indeterminado

$\mathrm{E}=$ Módulo de elasticidade longitudinal dos aços à temperatura ambiente

$E_{c}=42 \gamma_{c} \sqrt[1,5]{f_{c k}}=$ Módulo de elasticidade longitudinal do concreto ou

Energia cinética

$E_{p}=$ Energia potencial

$E_{t}=$ Energia total

$E_{T}=$ Módulo de elasticidade longitudinal dos aços à temperatura $T$

$F=$ Força genérica

$F_{a}=$ Força de Arrasto do Vento

$F_{\mathrm{C}}=$ Força de amortecimento

$\mathrm{F}_{\text {con }}=$ Força constante no tempo ( estática )

$\mathrm{F}_{\mathrm{e}}=$ Força elástica

$F_{f}=$ Fator de forma ou de massividade

$F_{H}=$ Força dinâmica aplicada pelo vento 
$F_{\mathrm{t}}=$ Força variável no tempo

$\mathrm{F}_{\mathrm{V}}=$ Coeficiente de amplificação dinâmica

$\mathrm{F}_{\mathrm{var}}=$ Força variável no tempo (dinâmica )

$F_{(z)}=$ Força aplicada na altura $z$

$G=$ Módulo de elasticidade transversal dos aços

$G_{a} ; G_{b}=$ Grau de engastamento das extremidades de uma coluna metálica

$H=$ Força horizontal genérica

$\mathrm{H}_{\mathrm{i}}=$ Força horizontal no ponto $\mathrm{i}$

$\mathrm{H}_{\mathrm{F}}=$ Força horizontal total ou final

$\mathrm{H}_{0}=$ Força horizontal inicial

$\mathrm{I}=$ Momento de inércia de uma seção

$\mathrm{I}_{\mathrm{x}}=$ Momento de inércia de uma seção em relação ao eixo $\mathrm{x}$

$\mathrm{I}_{y}=$ Momento de inércia de uma seção em relação ao eixo $y$

$I_{p}=I_{x}+I_{y}=$ Momento polar de inércia

$I_{t}=$ Momento de inércia à torção de uma seção

$\mathrm{K}=$ Matriz de rigidez de uma estrutura ou coeficiente de rigidez de uma

ligação

$L=$ Comprimento genérico ou de referência $=1800 \mathrm{~m}($ NBR 6123 $)$

$M=$ Matriz de massa ou momento nominal em geral

$\mathrm{M}_{\mathrm{a}}^{\prime}=$ Momento na viga de aço de uma viga mista, antes da cura do concreto

$M_{a} ; M_{b}=$ Momento aplicado na extremidade $a$ ou $b$ de uma viga

$M_{d}=$ Momento de cálculo

$\mathrm{M}_{\mathrm{i}}=$ Momento no ponto $\mathrm{i}$

$\mathrm{M}_{\mathrm{L}}=$ Momento na viga mista após a cura do concreto

$\mathrm{M}_{\mathrm{Fa}}=$ Momento final na conexão localizada na extremidade a de uma viga

$M_{F b}=$ Momento final na conexão localizada na extremidade $b$ de uma viga

$M_{E P}=$ Momento de engastamento perfeito

$M_{n}=$ Momento nominà resistente de uma viga

$M_{\mathrm{pl}}=$ Momento de plastificação de uma seção

$\mathrm{M}_{\mathrm{nt}}=$ Momento causado pelas ações que não provocam translações

$M_{\mathrm{lt}}=$ Momento causado pelas açōes que provocam translações 
$\mathrm{N}=$ Esforço normal nominal de compressāo

$\mathrm{N}_{\mathrm{d}}=$ Esforço normal de cálculo de compressāo

$N_{e x} ; N_{e y}=$ Força crítica de flambagem elástica nos planos $x z$ e yz

$P=$ Perímetro de uam figura ou força vertical genérica

$P_{C}=$ Potencial calorifico de um ambiente

$\mathrm{P}_{\mathrm{e}}=$ Força crítica de flambagem elástica

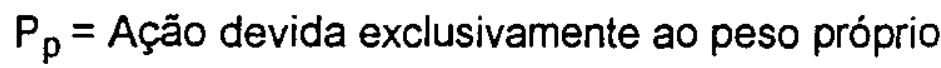

$Q=$ Quantidade de calor

$Q_{n}=$ Fluxo de cisalhamento na superfície de iteração aço/concreto de uma

$S_{1}=$ Fator de correção do relêvo ( NBR 6123)

$S_{2}=$ Fator de correção da altitude (NBR 6123)

$\mathrm{S}_{3}=$ Fator de correção estatístico ( NBR 6123)

$\mathrm{S}_{\mathrm{C}}=$ Ação variável ou de sobrecarga ( NBR 6120)

$T=$ Temperatura ou período em um movimento harmônico

$\mathrm{T}_{\mathrm{i}}=$ Trabalho no ponto $\mathrm{i}$

$V=$ Esforço cortante

$V_{\mathrm{C}}=$ Volume por unidade de comprimento de um perfil

$\mathrm{V}_{\mathrm{cr}}=$ Velocidade crítica do vento

$V_{\mathrm{d}}=$ Esforço cortante de cálculo

$V_{h}=$ Esforço cortante na mesa do perfil de aço de uma viga mista

$\bar{V}_{i}=$ Força fictícia devida ao efeito $P-\Delta$

$V_{k}=$ Velocidade característica do vento

$V_{0}=$ Velocidade básica do vento

$V_{n}=$ Resistência nominal a esforços cortantes de uma seção

$\bar{V}_{p}=$ Velocidade de projeto do vento para análise dinâmica

$W=$ Força devida ao vento ( AISC )

$\mathrm{W}_{\mathrm{a}}=$ Módulo de resistência à flexão do perfil de aço em uma viga mista

$\mathrm{W}_{\mathrm{ef}}=$ Módulo de resistência à flexão da seção mista homogeneizada, em estado elástico, considerando o deslizamento entre 0 aço e 0 concreto 
$W_{(t r) i}=$ Módulo de resistência à flexão da parte inferior da seção mista homogeneizada, sem deslizamento relativo

$W_{\mathrm{a}(\mathrm{tr}) \mathrm{s}}=$ Módulo de resistência à flexão da parte superior da seção mista homogeneizada, sem deslizamento relativo

$X=$ Vetor dos deslocamentos

$Z_{x} ; Z_{y}=$ Módulo plástico de resistência à flexão em torno dos eixos $x$ e y

\section{LETRAS LATINAS MINÚSCULAS}

$a$ = Lado maior de uma edificação

$a_{\mathrm{j}}=$ aceleração máxima em um deslocamento

$a_{o}=$ Aceleração de pico

$b=$ Fator de rajada, ou lado menor de uma edificação

$c=$ Calor especifico de um corpo

$d$ = Dimensão caracteristica ( NBR 6123) ou parte comprimida da laje em vigas mistas ( NBR 8800)

$e=$ Base neperiana

$e_{i}=$ Excentricidade na aplicação da força do vento em relação à face $i$

$f=$ Frequência natural de um elemento estrutural ou de uma estrutura

$f_{y}=$ Tensāo convencional de escoamento dos aços à temperatura ambiente

$f_{y, T}=$ Tensão convencional de escoamento dos aços a uma temperatura $T$

$f_{\omega}=$ Função resposta da frequência $\omega$

$f_{c k}=$ Resistência caracteristica do concreto aos 28 dias

$\mathrm{g}=$ Aceleração da gravidade

$\mathrm{h}=$ Altura em geral, ou tempo em horas

$h_{c}=$ Espessura da laje de concreto em uma seção mista

$h_{v}=$ Altura das aberturas de ventilação no cálculo da resistência ao fogo 
$\mathrm{i}$ = número de iterações ou número de partes em que foi dividido um todo ou ainda unidade imaginária $=\sqrt{-1}$

$i_{x} ; i_{y}=$ Raios de giração de uma seção em relação aos eixos $x$ e y

$k=$ Coeficiente de condutividade térmica ou de proporcionalidade elástica

$\ell=$ Comprimento genérico

$\ell_{1}=$ Comprimento ou largura de referência

$m=$ Massa de um corpo

$m_{i}=$ Massa do trecho i de uma estrutura

$m_{0}=$ Massa de referência

$p=$ Fator de rajada ( NBR 6123) ou ação com distribuição uniforme

$\mathrm{p}_{\mathrm{e}}=$ Pressão resultante da velocidade média do vento

$p_{d}=$ Pressão resultante da energia de rajada do vento

$p_{1}=$ Distribuição de densidades em probabilidade

$q$ = Pressão dinâmica do vento para análise estática

$\overline{\mathrm{q}}_{\mathrm{o}}=$ Pressão dinâmica do vento para análise dinâmica

$q_{(z)}=$ Pressão dinâmica do vento na altura $z$

$s=$ Constante utilizada na solução da equação do movimento ou distância entre duas edificações

$\mathrm{t}=$ Tempo

$u_{\mathrm{j}}=$ Deslocamento devido à resposta flutuante na análise dinâmica do vento

$v=$ Velocidade em geral

$\mathrm{x}=$ Deslocamento segundo 0 eixo $\mathrm{x}$

$x_{e}=$ Deslocamento estático segundo $o$ eixo $x$

$x_{d}=$ Deslocamento dinâmico segundo $o$ eixo $x$

$x^{\prime}=$ Primeira derivada do deslocamento $=$ velocidade

$x^{\prime \prime}=$ Segunda derivada do deslocamento = aceleração

$x_{T}=$ Deslocamento total segundo o eixo $x$ ( estático + dinâmico )

$x_{0}=$ Deslocamento inicial segundo $o$ eixo $x$ 
$y=$ Deslocamento segundo o eixo $y$

$\mathrm{y}_{\mathrm{c}}=$ Ordenada da parte comprimida de uma viga mista

$y_{0}=$ Deslocamento inicial segundo o eixo y

$y_{t}=$ Ordenada da parte tracionada de uma viga mista

$\bar{y}=$ Ordenada da linha neutra de uma seção mista

$z=$ Ordenada ou deslocamento segundo o eixo $z$

$z_{r}=$ Altura de referência $=10 \mathrm{~m}$ ( NBR 6123)

\section{LETRAS GREGAS}

$\alpha=$ Coeficiente de uniformização de tensões de cisalhamento ou razão entre a força de compressão e a força crítica de flambagem elástica ou ainda a razão entre os momentos em uma ligação $=M_{1} / \delta M_{2}$

$\beta_{1}=$ Variável dinâmica ( NBR 6123 ) ou coeficiente de estabilidade lateral de vigas ( NBR 8800 )

$\beta_{2}=$ Coeficiente de estabilidade lateral de vigas ( NBR 8800)

$\Delta_{\mathrm{i}}=$ Deslocamento de ordem i

$\Delta \mathrm{H}_{\mathrm{i}}=$ Incremento à força horizontal $\mathrm{H}_{\mathrm{i}}$

$\Delta_{0}=$ Deslocamento inicial

$\Delta_{\mathrm{T}}=$ Variação de temperatura

$\Delta_{\mathrm{u}}=$ Deslocamento final

$\Delta \mathrm{y}_{\mathrm{o}}=$ Deslocamento de segunda ordem

$\delta=$ Deformação em geral ou de segunda ordem

$\delta_{0}=$ Deformaçăo inicial

$\delta_{\mathrm{i}}=$ Deformação no ponto $\mathrm{i}$

$\phi=$ Fluxo de calor ou ângulo de fase do deslocamento em relação à força de excitação

$\phi_{\mathrm{i}}=$ Coeficiente de minoraçäo das resistências 
$\gamma=$ Modo fundamental de vibração

$\gamma_{c}=$ Peso específico do concreto

$\gamma_{\mathrm{f}}=$ Fator de majoração das ações ou das solicitações em análise linear

$\gamma_{\mathrm{f} 1}=$ Fator de majoração das açōes em análise não linear

$\gamma_{\mathrm{f} 2}=$ Fator de combinação das ações

$\gamma_{\mathrm{f} 3}=$ Fator de majoração das solicitações em análise não linear

$\lambda_{\mathrm{a}}=$ Indice de esbeltez da alma de um perfil

$\lambda_{m}=$ Indice de elbeltez da mesa ou aba de um perfil

$\lambda_{p}=$ Indice limite da região de proporcionalidade

$\lambda_{r}=$ Indice limite da região elástica

$\mu=$ Fator de amplificaçäo de flechas ou de deslocamentos

$\theta_{\mathrm{i}}=$ Ângulo que a tangente à elástica de uma viga faz com a horizontal no ponto i

$\rho=$ Coeficiente de redução da força de compressão ( NBR 8800 )

$\sigma=$ Tensão de tração nas vigas mistas em regime de proporcionalidade

$\omega=$ Frequência angular natural de um movimento harmônico ou frequência de excitação de uma ação

$\omega_{\mathrm{a}}=$ Frequência angular natural de um movimento harmônico com amortecimento

$\omega_{n}=$ Frequência angular natural de um movimento harmônico sem amortecimento

$\xi=$ Fator de amplificaçāo de um movimento dinâmico

$\psi_{\mathrm{i}}=$ Constante dinâmica (NBR 6123 )

$\psi_{0}=\gamma_{\mathfrak{f} 2}=$ Fator de combinação das ações

$\zeta=$ Fator de amortecimento em um movimento harmônico 


\section{RESUMO}

SÁLES, J.J. Estudo do projeto e da construção de edificios de andares múltiplos com estruturas de aço. São Carlos, 1995. 257p. Tese (Doutorado) Escola de Engenharia de Sāo Carlos, Universidade de São Paulo.

Este trabalho trata do projeto e da construção de edifícios de andares múitiplos com estrutura formada por perfis de aço e está ligado a duas áreas distintas da engenharia: a acadêmica e a prática. Para a acadêmica fornece uma quantidade de informações que permitem o desenvolvimento de diversas pesquisas sobre o assunto. Para a área prática fornece parâmetros que permitem discutir a viabilidade desta modalidade construtiva e as informações mínimas para o desenvolvimento do projeto e orientação da construção.

Para tanto, o conteúdo foi distribuído em 6 capítulos, onde no primeiro é feita uma análise da evolução destas construções, sob o ponto de vista arquitetonico e apresentadas algumas divergências quanto ao ensino e a aplicação desta modalidade construtiva,

No segundo capitulo são discutidos alguns aspectos construtivos ligados aos sistemas estruturais já utilizados, a racionalização por ocasiāo do projeto e o comportamento frente a incêndios.

No terceiro capítulo são analisados alguns aspectos estruturais, como os comportamentos estático, dinâmico, de segunda ordem e a influência da rigidez das ligaçōes na rigidez global da estrutura.

No quarto capitulo é abordado o sistema estrutural aporticado e desenvolvido o projeto de um edifício, com vinte pavimentos, que permite analisar o comportamento dos seus elementos constitutivos.

No quinto capítulo são analisados diversos sistemas estruturais aplicáveis a estas construções, como os aporticados; os com núcleos resistentes; em " outrigger" ; e os tubulares.

Finalmente, no sexto e último capitulo apresentam-se as recomendações e conclusões consideradas pertinentes e alguns temas para pesquisas posteriores.

Palavras chave: Aço - Edificios Andares Múltiplos - Projeto. 


\section{ABSTRACT}

SÁLES, J.J. Studie on the design and construction of multi-storey buildings with steel structures. São Carlos, 1995: 257p. Tese (Doutorado) Escola de Engenharia de São Carlos, Universidade de São Paulo.

The aim of this work is the design and construction of multi-storey buildings with steel structures linked to two different fields of the engineering: theorical and practical. For the formar it gives a great deal of information that allows the development of several researches about the topic. For the later it gives parameters which permit discussing the viability of this kind of system, and the least information for the development of the design and guidance of the construction.

For this purpouse the content of this work was divided in six chapters, starting whith an analysis of the evolution of these buidings on the architectonic point of view and also shows some disagreements related to teaching and the use of this kind of system.

In the second one, some constructive aspects linked to usual structural systems are showed, the racionalization during the projet and the behaviour facing fires are discussed.

The third chapter deals with some structural aspects as static and dynamic basis of second order and the influence of the stiffness of conections to determine the global stiffness of the structure.

In the fourth chapter the complete analysis of the framed structure analysis in a 20 storey-building was developed.

The fifth chapter discusses some alternative proposals to the structural system of the building treated in the late chapter; those with a resistent core system, an outrigger and the tube shaped structure.

Finally, in the last chapter the remarks and conclusions are presented and some topics for posterior researches are suggested.

Keywords: Steel - Multi-Storey Buildings - Design. 


\section{1- INTRODUÇÃO}

\section{1- OS EDIFÍCIOS DE ANDARES MÚLTIPLOS}

As civilizaçōes da antiguidade construíram diversas edificaçōes que, devido às suas características peculiares, tornaram-se símbolos de épocas, de estilos e de tecnologias construtivas. Como exemplos podem ser citadas as pirâmides egípcias, maias e astecas, os templos gregos, hindús e incas, a Muralha da China, o Coliseu Romano e diversas pontes e aquedutos do mesmo período.

De períodos mais recentes sobreviveram os castelos medievais e diversas catedrais, sinagogas e mesquitas.

Todas estas edificações surgiram nos períodos em que as civilizações que as construíram viviam seus melhores dias de fausto e riqueza, e destinavam-se a proteger tesouros materiais ou culturais e a delimitar domínios. Entretanto, o fato mais notável e duradouro que estas construções conseguiram, foi o de imortalizar seus construtores ou mesmo, no caso das pirâmides egípcias, também seus ocupantes.

Como outros pontos que estas construções, tão defasadas entre si ao longo do tempo, têm em comum podem ser citados: o material estrutural básico utilizado, no caso a pedra lavrada; o sistema construtivo empregado, a alvenaria de blocos; e as dimensōes destas construçōes, que ultrapassavam em muito as dimensões das demais construções contemporâneas. Parece, que a magnitude destas construções abrigava um desejo, consciente ou não, de dignificar e de personalisar seus construtores.

Até o advento da revolução industrial, não ocorreram mudanças neste comportamento coletivo em relação às construçכ̃es de grandes dimensões. Com a revolução industrial aconteceu uma alteração profunda nos hábitos urbanos, primeiramente na Europa e depois, no resto do mundo. 
As cidades que abrigavam indústrias acusaram um crescimento vertiginoso nas suas populações que, por motivos práticos, desejavam fixarse o mais próximo possivel dos centros destas metrópoles.

Surgiu assim, uma grande cońcentração populacional junto às fábricas, escritórios, bancos e lojas, que foi melhor atendida com a construção de edificações maiores e mais altas, pois assim também era aumentada e em muito, as áreas disponíveis.

Como consequência lógica desta procura por espaços junto aos centros, também ocorreu o aumento do preço destes espaços, o que incentivou ainda mais o crescimento vertical das edificações.

Este comportamento urbano alterou profundamente o perfil das cidades, onde residências térreas foram demolidas para dar lugar a edifícios comerciais e residenciais.

Este processo, iniciado em meados do século dezoito, continua até os dias atuais, uma vez que as cidades ainda estão crescendo e os seus centros se expandindo.

Entretanto, até o mejo do século dezenove, a tecnologia empregada na construção de edificaçōes, tanto comerciais como residenciais, possuía determinadas limitaçōes, impostas pelos materiais estruturais empregados, basicamente a madeira e o tijolo de barro cerâmico.

Estes foram os materiais empregados, desde as mais remotas civilizações, na construção de edificações de pequeno porte, como habitações ou demais construções onde o aporte de recursos não permitia, ou nāo justificava, o emprego do material mais nobre, a pedra lavrada.

Exatamente por suas limitações estruturais, a madeira e o tijolo permitiram, nesta época, a construção de edificações com altura relativamente pequenas, de quatro até seis andares.

Com o início da produção em escala industrial do ferro fundido e a seguir do ferro forjado, foi possivel, a substituição da madeira por estes metais, na construção de edifícios com maior altura. A evolução seguinte apresentou o aço e o concreto armado, como os materiais estruturais que permitiriam a construção das edificações, com as grandes dimensões da era atual.

Entretanto, as grandes construções das eras industrial e da atual diferem, das grandes construções das eras passadas, no material estrutural mas, principalmente nas suas finalidades, pois atendem a um grande número de pessoas, quer como moradia, quer como local de trabalho. 
Outro aspecto importante nas grandes construções modernas é a altura, que a exemplo da bíblica torre de Babel, não parece ter limitações. Dos tímidos 8 a 10 andares do final do século passado, atingiram mais de 100 andares no meio deste século e alguns sonham com construções de até 1000 metros de altura.

Entretanto, para viabilizar a construção dos edifícios atuais, diversos obstáculos precisaram ser vencidos. Entre estes o desenvolvimento de teorias de cálculo, que possibilitassem a análise do comportamento estrutural dos sistemas empregados; a criação e o desenvolvimento de novos materiais, mais resistentes e mais leves que os então conhecidos; a evolução dos sistemas de vedação, para melhorar o desempenho face às intempéries; a invenção e a evolução dos elevadores verticais, das escadas rolantes e demais utilidades, como $\circ$ ar condicionado central, rede de comunicações, eletrificação, etc.

Como resultado de toda esta evolução surgiram os edifícios atuais, alguns já denominados de "inteligentes", que permitem o planejamento e a construção de novas cidades e forçam o replanejamento das existentes, pois com as suas características de forma e de ocupação, estes edifícios alteram profundamente os serviços urbanos e redefinem o papel social das cidades.

Por todas estas peculiaridades, os edificios possuem diversas denominações que procuram traduzir uma ou mais das suas particularidades. Dentre estas, destaca-se a de "Edificios Altos", aplicada às construções onde a altura predomina em relação às dimensões em planta, ou às construçōes onde os efeitos das açōes horizontais são mais significativas que os causados pelas açōes verticais, ou ainda, aquelas com número de andares superior a um determinado valor.

Entretanto, como alerta TARANATH [ 38 ], uma construção com 30 andares pode ser chamada de alta para uma cidade pequena, como São Carlos, de média altura para grandes metrópoles, como São Paulo, ou Rio de Janeiro e de pequena altura se comparada às construções existentes em Chicago ou Nova Yorque.

Da mesma forma, ZIGNOLLI [ 42 ], lembra que existem construções onde os efeitos das ações horizontais sobrepujam os causados pelas ações verticais, e nem por isso são chamadas de ediff́cios, muito menos de construções altas. Como exemplos são citados os silos de cereais, os reservatórios e as torres de transmissão, entre outros. 
Neste trabalho, que aborda os edificios com estrutura em perfis de aço, independentemente das dimensões em planta, altura relativa, número de pavimentos ou ainda da relação entre solicitaçōes verticais e horizontais, adotou-se a denominação de "Edifícios de Andares Múltiplos" por ser mais abrangente, conclusiva e absoluta que as demais.

\section{2- OS SISTEMAS CONSTRUTIVOS}

Nas construçōes antigas, que sobreviveram até os dias atuais, foi empregado essencialmente a pedra como elemento construtivo, embora sem a mesma durabilidade, também foi empregado o tijolo de barro nas construções de menor vulto.

Estes dois materiais, a pedra e o tijolo, diferem entre si, basicamente na forma de obtenção, uma vez que a técnica construtiva é uma só, consistindo no empilhamento ordenado dos seus elementos.

Esta tecnologia sobreviveu ao longo do tempo, incorporando novos produtos, tanto nos elementos principais, como nas argamassas de rejuntamento ou de revestimento.

Surgiram outros formatos de tijolos, com dimensōes as mais variadas, fabricados com materiais diferentes, mas a maneira de erigir uma edificação permaneceu constante, ou seja, o assentamento de elemento após elemento, intercalado de argamassa, executado manualmente, de forma rotineira e monótona.

Essencialmente, até o inicio do século passado, esta era a única tecnologia utilizada em construçōes de grande vulto, como edifícios públicos ou residenciais e na quase totalidade das pontes da época.

Aliada a esta tecnologia, desde os seus primórdios, empregava-se a madeira como elemento estrutural nas construçōes de pequeno e médio porte, tanto de residências como de pontes. Associada com a alvenaria a madeira foi utilizada na forma de vigas, pisos e estruturas de coberturas.

Vale lembrar que estes materiais, o tijolo e a madeira, com as suas técnicas construtivas características, continuam a ser empregadas até os dias atuais, quase sem sofrer mudanças significativas. 
Entretanto, a obra que pode representar o ponto alto desta tecnologia, foi construida em Chicago, no ano de 1861. Trata-se do edifício Monadnock, que possui 17 andares e 64 metros de altura [ 22, 38 ].

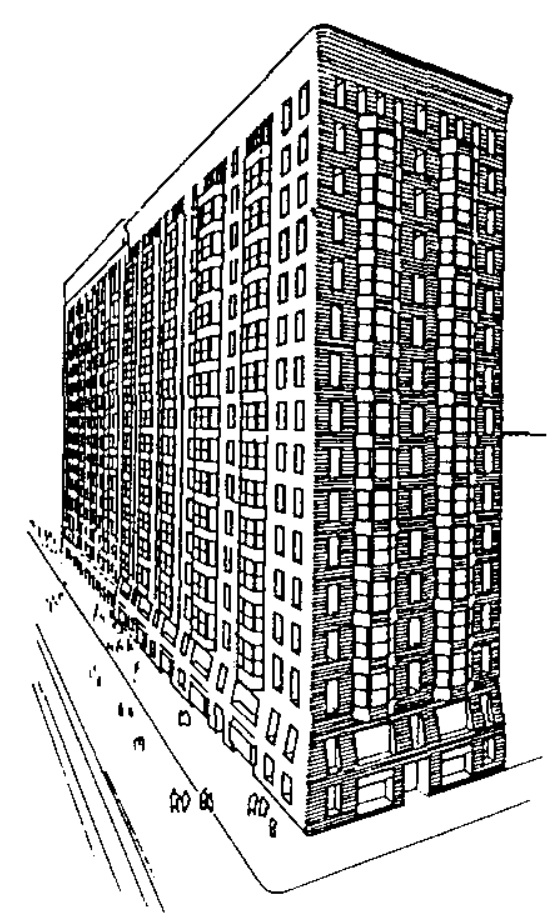

Figura 1.1 - Edifício Monadnock

Com o desenvolvimento da siderurgia, ocorrido no século 18 , foi possível a fabricação, em escala industrial, do ferro fundido com um custo muito menor que os obtidos até então. Só para ilustrar, vale registrar que na Inglaterra, em 1728, uma tonelada de ferro custava 12 libras, caindo para a metade deste valor em 1802 [ 22 ].

A aplicação de elementos estruturais de ferro fundido nas construções da época, foi apenas uma questão de tempo. Começou timidamente, em substituição à madeira, em vigas e arcos, tanto de edifícios como de pontes. O material foi substituído, porém a técnica construtiva empregada foi mantida.

É clássica a apresentação da ponte sobre o rio Severn, em Coalbrokdale na Inglaterra, construída em 1779, como a primeira obra importante a empregar o ferro fundido. Porém, a maioria dos autores nāo cita, ou não mostra, detalhes que permitam comprovar a aplicação da tecnologia desenvolvida para a madeira, na construção desta ponte. Vale observar a figura 1.2 [ 29 ]. 
A substituição pura e simples da madeira pelo ferro fundido, não alterou, de maneira substancial, a arquitetura da época. Permitia apenas construir com um material mais econômico e aparentemente mais duradouro.

Entretanto, no caso das pontes, logo foi verificado que o novo material permitia obter vãos maiores e arcos mais abatidos. Este fato gerou um grande desenvolvimento nestes projetos, que injustificavelmente não foi transferido, para o projeto de edifícios.
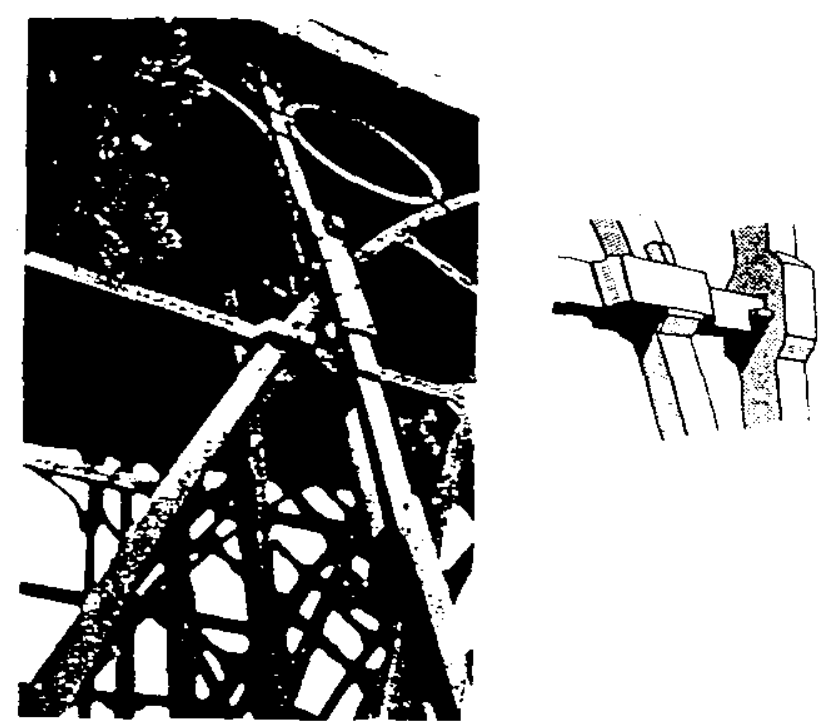

Figura 1.2 - Ponte em Coalbrokdale

Enquanto os vão das pontes aumentavam, atingindo então inimagináveis 175 metros, como na ponte sobre o rio Menai, Inglaterra, construída em 1815, ficando a sua estrutura totalmente aparente, nos edifícios procurava-se dissimular tal utilização, sem ocorrer aumento nos vãos a serem vencidos, ou na altura das edificações.

A primeira aplicação de colunas em ferro fundido parece ter sido na igreja de Sant'Ana, em Liverpool, construída em 1770. Esta aplicação resumia-se às colunas, em seção circular, que suportavam as galerias. Segue-se a mesma aplicação na igreja de Yorkshire, de 1774.

A aplicação de colunas circulares estendeu-se a teatros, fábricas e a edifícios comerciais, gerando surpresa a P.C.W. von Beuth, ministro do Comércio Prussiano que visitou a Inglaterra em 1823 e registrou "grande número de fábricas de oito e nove andares, com paredes tão finas como papel, com colunas e vigas de ferro" [22]. 
A seguir surgiu a colocação do ferro fundido nas fachadas dos prédios, ocorrendo o primeiro caso em 1829, na Pensilvânia, no Edifício do Banco "Farmer's and Miners". Porém, toda a fachada foi construída em ferro fundido, não ocorrendo destaque para a estrutura .

A associação do ferro com o vidro surgiu na cúpula "Halles au Blé ", em Paris, projetada em 1809 e construída em 1811. A utilização do vidro em cúpulas de estufas já vinha sendo empregada desde o início do século 18 mas, com esta obra, os projetistas de estufas perceberam as duas vantagens principais da utilização do ferro: a pré-fabricação total dos elementos e vãos maiores que os construidos anteriormente.

Com a construção da estufa de "Chats-Worth", em 1837, que possui 83 metros de comprimento, 40 de largura e 20 de altura ficou definido 0 sistema construtivo a ser empregado no Palácio de Cristal. Este edifício, construido em 1851 para sediar a primeira exposição internacional, possuia 556 metros de comprimento e era totalmente em ferro e vidro.

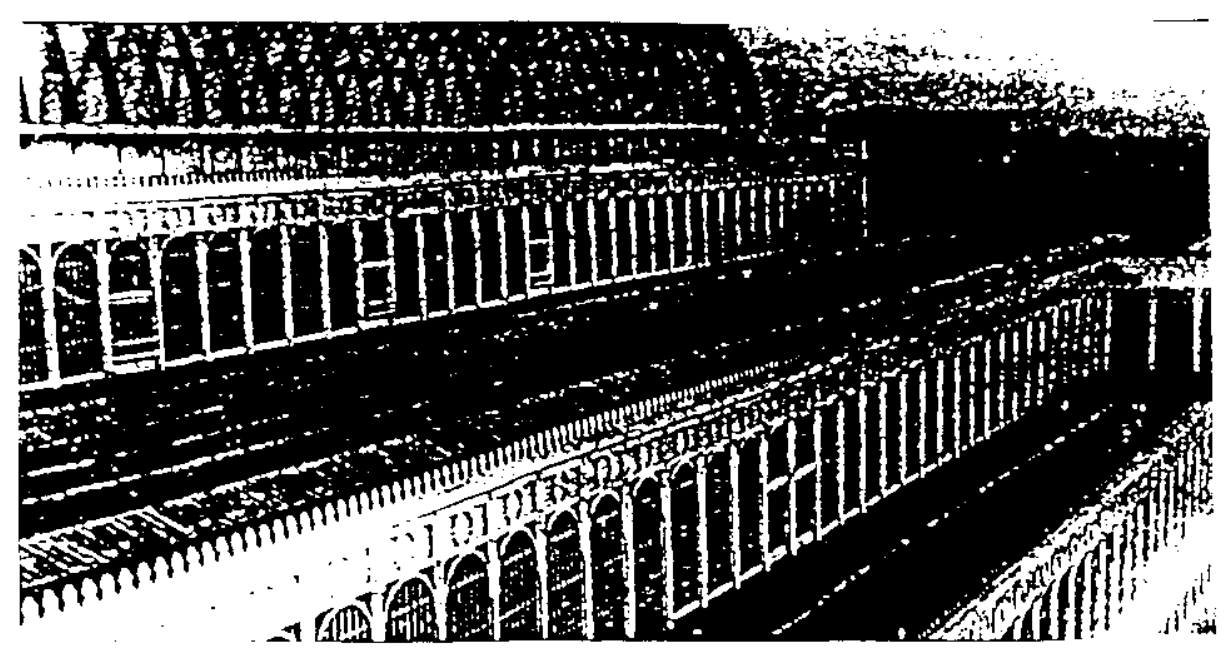

Figura 1.3 - Palácio de Cristal

O sistema de pré-fabricaçāo permitiu fabricar e montar toda a obra, no exíguo prazo de doze meses. Este edifício foi o exemplo mais importante da construçāo com fèrro e vidro do século 19 [22, 29 ].

A evolução das coberturas atingiu também as construçōes destinadas a mercados de troca e a estações ferroviárias, como a de "Broad Street", na Filadélfia de 1843, ou a de "New Street", em Birmingham de 1854, ou ainda - Mercado Coberto de Paris de 1852. 
Com o início da fabricação de perfis de ferro laminado e forjado, em 1783 , surgiram os perfis retos, que logo cairam no gosto dos construtores de pontes, que os aplicaram, por exemplo, na "Wearmonth", em Londres, com 70 metros de vão, em arco abatido e a do rio Neva em Petesburgo, em vigas treliçadas com 170 metros de vão, construída em 1840.

Apenas seis anos mais tarde era concluída a ponte Britania, sobre 0 estreito de Menai, no mar da Irlanda, com 70 metros no vão central, que foi pioneira na utilização de viga caixão e na análise do sistema estrutural via modelo reduzido.

Por esta época foram construídos os edifícios da biblioteca "St. Geneviéve", em 1862 e do "Coal Exchance", em 1864, ambos em Paris. A biblioteca possui no seu interior 16 colunas de ferro que suportam a cúpula de terracota e vidro, e o banco expõe o ferro fundido em colunas, fachadas, balaustres e demais acabamentos.

Paralelamente a todas estas realizações surgiu em 1856 o processo industrial de conversão de ferro em aço, desenvolvido por Bessemer, que permitiu a produção de aço em escala industrial. Foi este o processo que permitiu a difusão comercial do aço, pois tornou um material raro em um produto comercial, aumentando a oferta e reduzindo o custo dos seus produtos. Em 1864 surgia o processo Siemens-Martin, que propiciou um aumento considerável na produção mundial. Em 1879 o processo Thomas, que completou o ciclo de obtenção do aço [ 22, 29 ].

Nesta ocasião já haviam sido construídas a ponte do Brooklin, em 1870 com 478 metros no vão principal, e a ponte "Firth of Forth", de 1873 com 521 metros de vão.

Nestas obras a presença do aço revelara-se de fundamental importância, embora a primeira ponte a utilizar unicamente o aço como material estrutural, tenha sido a "Eades", sobre o rio Mississipi, em St. Louis, construída em 1867 [ 22, 29]

Alternando o uso de perfis de aço com elementos de ferro forjado e fundido, foram construídos os arcos da Galeria das Máquinas, na Exposição Internacional de Paris, de 1889. Possuiam 115 metros de vão e 45 metros de altura na cumeeirà. Foram os maiores já construídos.

Foi para esta mesma exposição que Gustave Eiffel construiu a torre que se tornou um dos símbolos da cidade. Ironicamente a torre foi construída apenas para acompanhar a exposição e mostrar as possibilidades que o aço oferecia aos construtores 
Previa-se a sua desmontagem, uma vez concluída as festividades mas, o impacto que a mesma causou foi tão grande, que as autoridades municipais decidiram-se pela sua conservação. Com seus 300 metros de altura, a torre Eiffel ficou sendo a construção mais alta do mundo, até o final da primeira guerra.

Como é fácil de perceber, pontes, torres e pavilhões de exposições, ficavam com suas estruturas aparentes, propiciando assim uma melhor difusão dos materiais e dos sistemas estruturais empregados. Entretanto, os arquitetos continuavam a esconder a estrutura dos edificios, apesar das incursōes bem sucedidas já realizadas nas demais modalidades.

A evolução das pontes e torres deveu-se, principalmente, ao pioneirismo dos engenheiros. Entretanto, a inclusão das estruturas de aço nos edifícios passava, como ainda passa, pelo crivo dos arquitetos, que também começavam a contar, no final do século passado, com um outro material estrutural, o concreto armado.

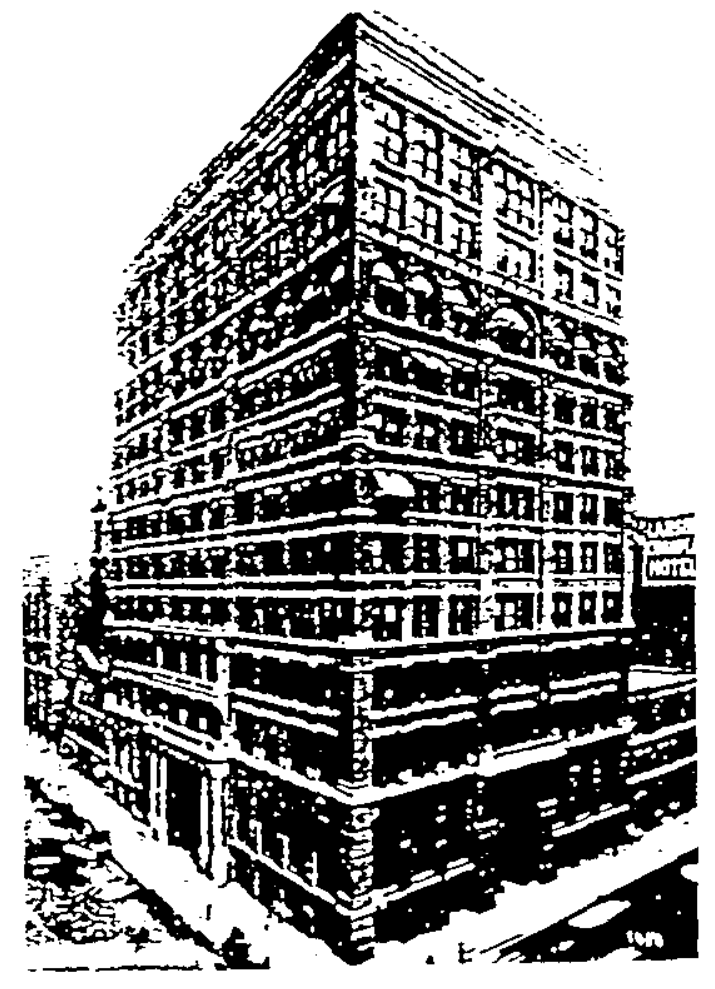

Figura 1.4 - Edifício Home Insurance

Entretanto, o incêndio de Chicago foi o impulso que faltava para projetar o aço como o elemento estrutural capaz de reconstruir a cidade, no menor prazo possivel. Surgiram assim diversos edificios como o "Leiter I", de 1879, o "Home Insurance" de 1885 e o "Tacoma" de 1888, entre outros 
Firmava-se assim, a primeira Escola de Arquitetura em Edificios de Aço, conhecida como de Chicago, fundada por Willian Le Baron Jenney, que garantiu, na virada do século, a primazia neste tipo de construção, à cidade de Chicago, que possuia mais edifícios em aço do que todas as demais cidades americanas juntas.

Entretanto, apesar de difundida a nova tecnologia estrutural, estes edificios em nada se diferenciavam, externamente, das imensas torres de alvenaria até então construidas.

Devido à magnitude das dimensōes que podiam ser construídas, surgiu a vontade de imprimir um caráter histórico, de impressionar ou mesmo de dignificar suas construções, como ficou demonstrado nas fases posteriores dos seguidores da Escola de Chicago, quando a maioria das construções desta época, retornou ao estilo neociássico, que melhor atendia esta tendência histórica.

A imparcialidade que dá a esta solução anacrônica um certo encanto, se perdeu nos edifícios construidos no final da década de 90 , que sucumbiram à influência clássica da arquitetura que veio da costa leste americana, a chamada "New York Fashion".

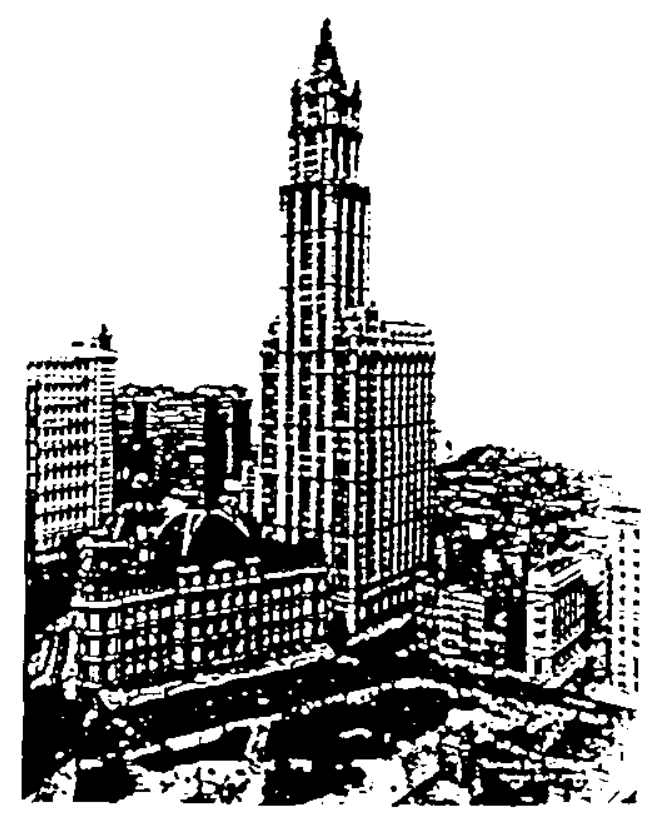

Figura 1.5 - Edifício Woolworth

Neste década, a posição de liderança foi assumida por Nova Iorque, não somente no número de edifícios construídos mas também em altura e em mérito arquitetônico. 
Num período que durou quase 40 anos, o espetáculo de ecletismo histórico foi repetido, com todos os estilos do passado refletidos na arquitetura dos edifícios altos, então denominados de arranha-céus [ 22 ].

Neste período foram construídos, o "Woolworth Tower" em 1915, com 55 andares e 234 metros de altura, considerado até 1930 o edifício mais alto do mundo. Em 1929 o edifício da "Chrysler" com 75 andares e 320 metros de altura e em 1931, o "Empire State", com 102 andares e 380 metros de altura, que foi, durante os 40 anos que se seguiram, sem dúvida alguma a construção mais alta do mundo.

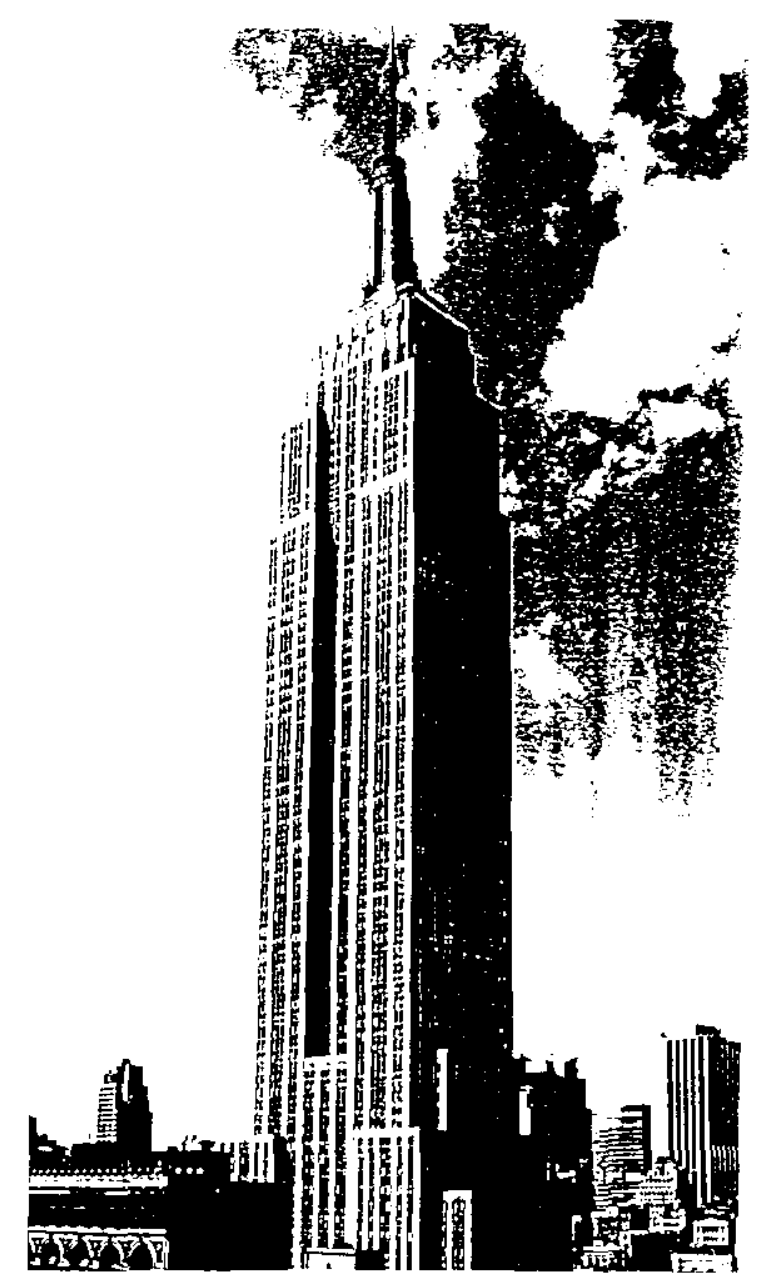

Figura 1.6 - Edifício Empire State

Na Europa entretanto, a aplicação de estruturas de aço ficou restrita a uns poucos edifícios. Até 1900 , os pisos eram feitos com vigas de aço, mas começou-se a dar preferencia às vigas de concreto, não só pela economia que esta substituição proporcionava, como também pela maior resistência ao fogo que o concreto possui. 
Após a segunda guerra, dois fatos contribuiram para a retomada das construções com aço. O primeiro, a exemplo da Chicago devastada pelo incêndio, tratava-se de reconstruir um continente e o segundo, era alocar a mão de obra especializada que fora uitilizada na fabricação de navios e aviōes.

Mais uma vez foi o aço empregado para construir com a rapidez que a situação exigia.

Entretanto, as bases deste desenvolvimento foram plantadas antes da guerra pela Bauhaus, Escola de Arte fundada e dirigida por W. Gropius, na República de Weimar, depois substituído por Ludwig Mies van der Rohe, que a dirigiu até 1938, quando, não resistindo às pressões nazistas, emigrou para os Estados Unidos, ligando-se ao IIT, "Illinois Institute of Technology" de Chicago, encerrando o sonho da Bahaus.

$\mathrm{Na}$ Europa, enquanto os engenheiros navais e aeronáuticos revolucionavam os projetos de pontes e viadutos, os arquitetos, em particular os alemães, adotaram e procuraram dar grande publicidade às conquistas da Bauhaus, que parecia a corporificação dos ideais de liberdade e progresso.

Porém, como não possuiam experiência nos novos métodos de construir e como logo ficaram sobrecarregados de trabalho, começaram a violar os princípios básicos da tecnologia das construções e as regras utilizadas na obtençāo de ambientes internos agradáveis, fazendo com que a "nova" arquitetura caísse no desagrado do público.

Esta crítica é especialmente aplicável à arquitetura do "Gridiron", literalmente das grades de ferro, mas que se aplica às estruturas de edificios cujas fachadas ficavam marcadas por uma grelha uniforme de elementos salientes, horizontais e verticais.

$O$ protótipo desse tipo de estrutura foi criado por $H$. Salvisberg, para o edifício "Bleicherhof" de Zurique, construído em 1938.

Durante a década de 40 , este exemplo foi seguido por um grande número de edifícios, todos seus vizinhos, ficando o estilo conhecido, como Escola de Zurique [ 22,29 ].

$\mathrm{Na}$ reconstrução alemã, muitos arquitetos empregaram este estilo, gerando nos anos 60 uma revolta contra o princípio da grade, que fez surgirem construções com as formas em planta as mais variadas como asas de aviāo, rins, serpentes, hexágonos, etc. Como exemplos, o edifício da Pirelli em Milão, o Itália e o Copan, em São Paulo. 
Nos Estados Unidos, entretanto, o dominio de van der Rohe, durante os 20 anos em que permaneceu no IIT, foi absoluto. Neste período ele projetou os edifícios do novo "campus" do Instituto, considerados como um marco importante na arquitetura com aço, o "Lake Shore Drive", de 1950 e a sua obra prima que é o edifício da "Seagran", na Park Avenue, de 1952, que consolidaram a segunda escola de Chicago.

A reação contra os princípios da arquitetura de van der Rohe pode ser visualizada nos projetos de Eero Saarinen.

O primeiro e mais importante destes projetos é o do Centro Técnico da "General Motors", concluído em 1955. Segue-se o projeto do Centro de Pesquisa da IBM, com 300 metros de comprimento, em dois andares e em forma de segmento circular.

A tecnologia desenvolvida para as estruturas de aço, com resultados extremamente positivos, utilizou o sistema de pré-fabricar seus componentes, reservando apenas a montagem para o local da obra.

Esta metodologia foi a seguir transferida para os elementos não estruturais, pré-fabricando os painéis de fechamento, que substituiriam os painéis de alvenaria, que empregavam muita mão-de-obra, além de não acompanhar o ritmo de construção que a nova tecnologia permitia desenvolver.

A pré-fabricação dos painéis de fechamento atingiu elevado grau de sofisticação, incluindo janelas, vidros, portas, até a pintura de acabamento.

No caminho natural do desenvolvimento, o passo seguinte foi 0 de fabricar painéis com maior altura, atingindo, em alguns casos, até três andares.

O emprego do vidro como fechamento, sempre foi muito utilizado pelos arquitetos, desde as estufas do século 18 , passando pelo Palácio de Cristal e chegando aos edifícios dos anos 50 , quando aliando-se à tecnologia de pré-fabricação de painéis e ao princípio do "Gridiron", deu origem às fachadas totalmente envidraçadas, denominadas paredes-cortina.

A primeira aplicação, de uma parede-cortína, totalmente préfabricada, foi no edifício da Federação Francesa da Construção, em Paris, projeto de Jean Prouvé, de 1949.

Nos Estados Unidos, os primeiros edifícios a utilizarem a paredecortina foram 0 da Alcoa, em Pittsburgh, projetado por Hardison e Abramowitz e o "Lever House", em Nova lorque, projeto da Skidmore e Associados, construídos logo após os edifícios do "Lake Shore Drive". 
$\mathrm{Na}$ Europa, as melhores expressōes para a parede-cortina encontram-se em Dusseldorf, nos edificios da Mannesmann, projetado por Schanes-Der-Esleben e Knothe e o "Phoenix-Rheinrohr" ( atual Thyssen ), projetado por Henrich e Petschnigg, ambos de 1957.

A reação contra os fechamentos totalmente de vidro, alterou um pouco a composição das paredes-cortina. Buscando efeitos mais rústicos e custos menores que 0 do vidro, surgiram as aplicações de materiais mais convencionais. Foram utilizadas placas de pedra natural ou artificial, de alumínio, de aço escovado ou mesmo de concreto pré-moldado, como no edifício da Pan-American, em Nova lorque, projetado por Gropius, Roth e Belluschi, de 1963.

Continuando a reação contra a Escola Miesiana, foi construído em 1961 o Centro Administrativo da "Hart Ford Insurance Company" projetado por Skidmore, Owingg and Merril, com um núcleo interno todo em concreto armado. Os dois materiais estruturais mais empregados, sempre separados, foram unidos de maneira indissolúvel neste projeto e nos demais que se seguiram.

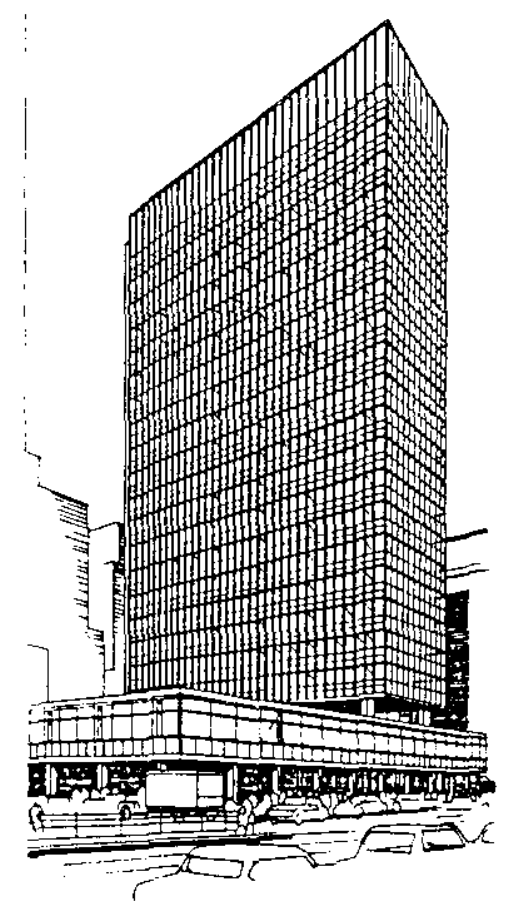

Figura 1.7 - Edifício Lever House

Ainda de Saarinen são os edifícios da CBS em Nova lorque, de 1964, e de Skidmore e Associados os edificios "Chestnut de Witt Apartment" e o "One Shell Plaza", de Houston, Texas, todos no sistema tubular. 
No edifício da Alcoa, em São Francisco, foi aplicado um sistema de contraventamentos às fachadas do edifício. Este sistema teve seu expoente máximo no "John Hancock Center", projetado mais uma vez por Skidmore e Associados em 1968.

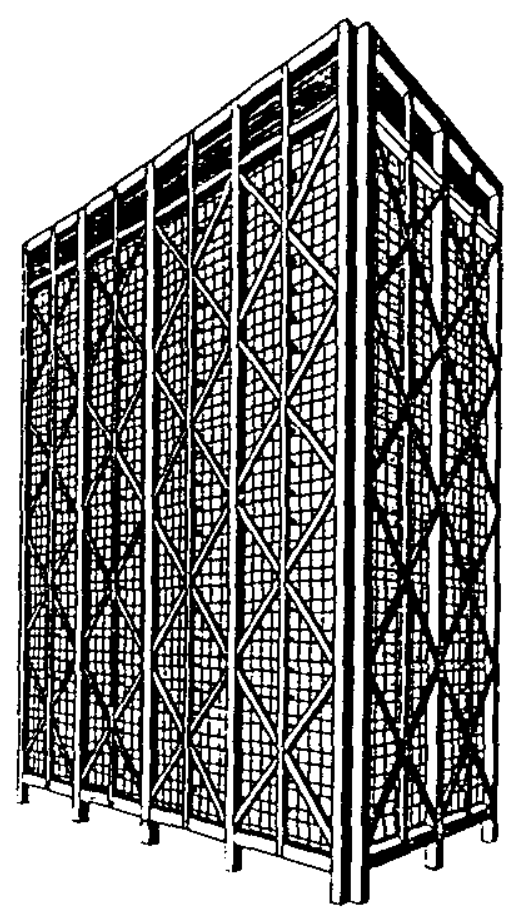

Figura 1.8 - Edifício da Alcoa

A construção do "World Trade Center", em Nova lorque, em 1973, com 411 metros de altura e 110 andares, marcou o ponto alto dos edifícios em aço, mas foi a torre da "Sears", construída em Chicago na mesma época, com seus 445 metros de altura e 109 andares, que assegurou para 0 aço a primazia na construção de edifícios realmente altos.

O edifício da "Sears" também representa a supremacia da segunda Escola de Chicago, na construção de edifícios em aço, pois até os dias atuais, é a construçāo mais alta do mundo, abrigando cerca de 25.000 pessoas em suas instalações e a sua construção foi realizada no exíguo prazo de 15 meses.

Fora o gosto pela quebra de recordes, observa-se em todo o mundo uma utilização cada vez mais intensa das estruturas de aço em edifícios de andares múltiplos e a menos dos exemplos da arquitetura "High Tech" de Willian Rogers e Normam Foster, que só o tempo dirá se gerarão uma nova escola, encontram-se as mais diversas aplicações de forma, sistema estrutural, metodologia construtiva e dimensōes. 


\section{3- DISCUSSÕES NA EVOLUÇÃO DOS EDIFICIOS}

Durante a evolução da construção de edificios de andares múltiplos, pode ser observado o papel de destaque e mesmo de decisão assumida pelos arquitetos. Entretanto, esta postura foi adotada ao longo do tempo e a custa de discussões e mesmo assumida concorrência entre as diversas escolas.

O papel dos engenheiros não foi muito diferente, pois da mesma forma que os arquitetos, estes se lançaram a uma concorrência que, a luz dos anos atuais, trouxe inúmeros desenvolvimentos à construção civil.

Uma das mais saudáveis discussões que ocorreram entre estes profissionais, foi sobre a opção de manter ou não a estrutura de aço aparente.

Para comprovar seus argumentos cada um dos lados executou construções dentro das suas teorias e o resultado prático que restou foi o desenvolvimento, até um alto grau de eficiência, dos dois sistemas.

Atualmente, a opção de manter a estrutura aparente envolve muita criatividade dos profisionais envolvidos, muito mais que a opção de ocultála, exigindo maiores considerações técnicas, operacionais e economicas, pois será necessário decidir qual o material e o tipo de tratamento a ser empregado na superfície exposta do aço.

O emprego de aços patináveis tem sido a solução mais usual, porém este emprego por si só, não garante a qualidade arquitetonica, muito pelo contrário, exige um tratamento mais cuidadoso por ocasiāo do projeto, que só é possível aos profissionais com considerável experiência, requerendo também um controle do seu comportamento ao longo do tempo.

A cor da pátina que recobre estes aços, confere-lhes dignidade, maturidade e um agradável efeito visual, tal como certos tipos de madeira em processo de envelhecimento. Entretanto, a água da chuva pode remover parte desta pátina, que escorrendo pela fachada, fatalmente manchará os elementos que não forem do mesmo tipo do aço empregado.

Outra opção é a proteção do aço com pintura, existindo "primers" inibidores de corrosão extremamente eficientes, que foram desenvolvidos para a proteção de estruturas em ambientes extremamente agressivos.

Para acabamento também já existem tintas com vários tipos proteção, de pigmentos, de cores e de texturização [ 29 ]. 
Entretanto, não há inconveniente em revestir, recuar ou mesmo esconder totalmente a estrutura. Este revestimento pode ser executado com chapas finas de aço ou alumínio, painéis de esquadrias, alvenarias, etc.

A escolha do tipo de proteção, deve estar de acordo com o aspecto final desejado para a construção e a vida útil prevista para a mesma, lembrando que os aços patináveis não são recomendados para estruturas com previsão de vida útil inferior a 15 anos, que é o tempo ideal para a estabilização da pátina.

Outra discussão que se prolongou, de forma até cansativa, diz respeito às instalações e aos serviços. Nos primeiros edifícios, estes itens não eram uma parte significativa tanto do projeto quanto da construção. Atualmente, para os primeiros edifícios chamados de inteligentes, estes serviços representam uma parte substancial, tanto do projeto como do acabamento.

Entre estes serviços incluem-se: a passagem de cabos, dutos e tubos destinados à circulação de água, ar, energia elétrica, tele-comunicações, redes de computadores; a localização e a alimentação de equipamentos de elevação e transportes, garagens, helipontos, etc.

A divisão de opiniōes ocorre, quando deve ser decidido se o caminho dos serviços ficará oculto ou não.

Técnicamente não existem vantagens em esconder em galerias, forros falsos ou chaminés, estes serviços porém, a decisão de deixá-los aparentes, tal como a estrutura, exige um cuidado estético maior desde 0 projeto até a montagem final.

Este cuidado deve ser estendido desde o sistema de limpeza externa dos vidros, à possiveis alterações nas finalidades da construção, chegando, se possivel, a prever futuras ampliaçōes.

A adequação da estrutura de aço aos serviços é das mais tranquilas, possuindo soluções já consagradas, como a utilização de vigas com almas vazadas, de altura variável, ou mesmo a inclusão, de maneira fácil e rápida, de novos perfis ou o reforço dos já instalados.

Outro ponto de controvérsia pode ser encontrado nos edifícios inteiramente revestidos com vidro.

As primeiras construçōes a utilizarem estes fechamentos, foram executadas ainda no século 19, quando da introdução do ferro em substituição à madeira. Entretanto, estas obras eram coberturas, como a Galeria D'Orléans ou mesmo o Palácio de Cristal. 
Na evolução deste tipo de fechamento, o fator decisivo foi o atraso da tecnologia de fabricação do vidro em relação à tecnologia do ferro, pois a modulação do palácio de cristal foi baseada nas dimensões limitadas das placas então produzidas, que não ultrapassavam 1,25 m de comprimento.

Somente na década de 20 tornou-se possivel a produção, em larga escala, de vidros planos com grandes dimensões. Entretanto, só em 1939 o vidro foi utilizado, em larga escala em uma estrutura de aço, foi na Casa do Povo em Clichy, França.

Porém, a arquitetura praticada por van der Rohe exigia o vidro, como pode ser visto nos apartamentos do "Lake Shore Drive", por ele projetados.

As paredes em vidros, projetadas naquela época, eram técnicamente imperfeitas, mesmo para os padrōes e exigências que então vigoravam, pelo fato de serem formadas por uma só lamina. Como pode-se perceber, conforme HART [ 22 ], "os residentes dos apartamentos do Lake Shore Drive divertiam-se soprando pequenas aberturas na espessa camada de gelo que se formava em suas janelas no inverno, principalmente quando muitas pessoas concentravam-se em uma sala, o que elevava a umidade do ar no interior".

Não podem ser também ignoradas, as perdas de calor e o efeito "estufa" que acontecem em grandes áreas envidraçadas, assim como a fratura frágil, outra fraqueza dos vidros então produzidos.

Aparentemente esses problemas já estavam solucionados quando da construção das fachadas em vidro na tonalidade verde do "Lever House", ou na tonalidade marron-dourada do edifício da "Seagrans", exatamente na cor do uísque, elevando, conforme alguns afirmam, a venda do produto [ 22 ].

A partir dos anos 50, foram desenvolvidos os vidros duplos, que eliminam os problemas de refrigeração e acústica; os temperados, aramados e de segurança, que podem ser utilizados, sem medo algum, até em sacadas ou clarabóias.

Portanto, combinando cor, textura e capacidade de absorção de luz podem ser empregadas fachadas totalmente envidraçadas tanto em regiões frias como em regiões quentes.

Finalmente, a última e a mais antiga polêmica: o aço e o concreto armado. Nascidos na mesma época e mesmo não sendo possivel conceber concreto armado sem aço, ou aço sem estar combinado com concreto, cada produto gerou sua escola e a polarização entre as mesmas é enorme. 
Esta polarização de opiniōes leva os integrantes das duas escolas a verdadeiras batalhas, tanto teóricas como práticas, em escritórios de projeto, universidades, congressos, seminários, publicaçōes técnicas e até aos órgãos de classes.

Entretanto, estas divergências foram e continuam sendo altamente estimulantes para o desenvolvimento dos dois sistemas.

Historicamente, sabe-se que os dois sistemas nasceram logo após a formulação da teoria da elasticidade, quando a hiperestática não estava muito desenvolvida.

As construçōes em aço desta época, foram construídas tendo por base os conhecimentos adquiridos com outro material estrutural, a madeira, sendo que para esta, procurava-se projetar estruturas as mais isostáticas possiveis.

Entretanto, o natural monolitismo do concreto, que pode dar origem a estruturas com um grau mais alto de hiperestaticidade, obrigou os calculistas a aprimorarem e a desenvolverem novos processos de cálculo.

Assim, as soluções desenvolvidas para as estruturas de concreto, foram transferidas para as de aço, tornando a celeuma ainda mais acirrada.

Com os desenvolvimentos da solda elétrica, dos parafusos e dos aços de alta resistência, as estruturas de aço conseguiram manter um certo campo de aplicação e de domínio incontestável, mesmo com o desenvolvimento dos concretos de alto desempenho, da aplicação de protensão e de aditivos.

Este campo de aplicação, onde as estruturas de aço representam a única opção viável, tanto técnica como econômica, fica restrito à obras com grandes vãos, grandes alturas, ou quando necessita-se de rapidez de execução.

Entretanto, mesmo nesses casos a estrutura de aço, quase sempre, será assentada sobre fundações de concreto ou terá lajes de concreto formando os pisos dos andares, ou os núcleos de elevadores e de escadas.

Evidentemente, nos dias atuais, os dois sistemas podem ser analisados por uma mesma teoria, ou programa computacional, mas afirmar que um é melhor que o outro, tanto do ponto de vista da técnica como da economia, é no mínimo demonstrar falta de conhecimento em um dos sistemas, normalmente daquele que é apresentado como inferior. 


\section{4- OS EDIFÍCIOS DE AÇO NO BRASIL}

Até a vinda de D. João VI para o Brasil, era proibida a instalação de indústrias na então Colônia. Com a presença da corte no Rio de Janeiro e a necessidade imperiosa de adaptar a cidade, mesmo que de forma incipiente, aos padrões europeus, foi necessário importar diversos produtos como chapas de ferro, louças cerâmicas, tubos de chumbo e até pregos e ferramentas.

Para permitir estas importações foi necessário abrir os portos; para acelerar o desenvolvimento e dissiminar um pouco de cultura, foram criadas a imprensa, as escolas tanto de nível médio como superior e permitida a instalação de indústrias, com a revogação do alvará real de 1785 e em 1816 veio a missão francesa para ensinar as "novas" técnicas européias de construir, trazendo mestres artísticos, serralheiros, ferreiros, marceneiros e um engenheiro mecânico.

Esta foi a primeira mudança substancial na maneira de construir e de habitar, em nosso país. A segunda foi motivada pelas alterações sócioeconomicos e tecnológicas ocorridas na segunda metade do século, com a revolução industrial, que trouxe novas condições de transporte ferroviário, maritimo e fluvial, introduzindo um novo elemento: as estruturas préfabricadas.

Os tratados políticos-comerciais que o Brasil mantinha com a Inglaterra, favoreceram a concessão do sistema ferroviário às compahias inglesas, que deste modo trouxeram as primeiras pontes e edifícios de estações.

A importação era completa, pois incluía desde estruturas, vedaçōes, coberturas, ornamentos, gradis, até escadas, que eram aqui montadas conforme desenhos e instruções que as acompanhavam.

A arquitetura oficial deste período ficou caracterizada pelas estruturas e ornamentos de ferro, mesmo quando produzidos com os recursos locais. Como exemplos desta época, além das estações e pontes ferroviárias, em uso até os dias de hoje, podem ser citadas as cidades históricas de Mariana e Ouro Prêto.

A importação de materiais da Europa persistiu até a primeira guerra, passando pela reforma urbana do Rio de Janeiro e a expansão para o oeste paulista. 
Com a guerra, cessaram as importações e escassearam no mercado produtos como perfis de ferro ou de aço, cimento em barricas, vidros planos e vergalhões de aço para concreto.

Durante a guerra, alguns produtos foram importados dos Estados Unidos e outros começaram a ter incentivada a sua produção a nível nacional, entre estes, o ferro gusa, que no final da guerra atingiu a produção anual de quase 10.000 toneladas anuais.

$\mathrm{Na}$ década de 20 foi iniciada a produção de cimento e a primeira fábrica começou a operar em 1926, com a capacidade inicial de 13.000 toneladas/ano. Foi também instalada, em 1921, a Companhia Siderúrgica Belgo-Mineira, que junto com outras pequenas fundiçōes, conseguiu fechar a década produzindo 35.000 toneladas/ano, enquanto a produção de cimento atingia, em 1929, a marca de 96.000 toneladas/ano[ 29 ].

Apesar das grandes revoluções sócios-culturais que alteraram os padrōes europeus e norte-americanos, antes e depois da primeira guerra, e que se fizeram sentir na arquitetura, na construção, nas indústrias e nas artes, aqui no Brasil continuava-se a construir com os mesmos padrões do século passado, fazendo com que até hoje muitos confundam a década de 20 no Brasil, com a "Belle Époque" da Europa do século passado [ 29 ].

Somente em 1922, com a semana de arte moderna em São Paulo e com o movimento regionalista do Recife, de 1926, é que começou um movimento cultural visando destruir a influência estrangeira, que desde 0 tempo de D.João Vl, dominava o país.

Os resultados desta pregação apareceram em 1935, quando o Ministro da Educação, Gustavo Capanema, com o parecer favorável de Le Corbusier, aprovou o projeto para o prédio do Ministério que foi construído no Rio de Janeiro. Da equipe vencedora faziam parte os arquitetos Lúcio Costa, Carlos Leão, Jorge Moreira, Affonso Eduardo Reidy, Oscar Niemeyer e Ernani Vasconcelos.

A maioria dos arquitetos brasileiros ainda seguia as regras clássicas da composição, ensinadas nas escola chamadas de Belas Artes, e sentiu-se desalojada por esses pioneiros que, voltados às teorias de Le Corbusier, tomavam a liderança da arquitetura nacional, criando um clima de euforia e criatividade em que todos sentiam estar fazendo algo de novo e de realmente importante.

Repetia-se no Brasil as idéias que criaram a Bauhaus, o "taliesin" de Frank Lloyd Wright e dos "ateliers" de Le Corbusier e Alvar Aalto. 
Assim, à sombra do Estado Novo, quando foi criado o Ministério da Educação, a "moderna" arquitetura brasileira começava a tomar impulso, dando início à chamada Escola Burocrática, que mais tarde iria repetir, na concepção e na construção de Brasilia, arquétipos dessa mesma arquitetura, que nasceu irreversivelmente comprometida com o concreto armado, graças às inúmeras versōes da "Unité d'Habitation de Marseilles" que proliferaram em inúmeras cidades brasileiras, concentradas mais na semelhança visual do que em interpretar a idéia original do mestre [ 29 ].

Vale lembrar que nesta época estava quase concluida a construção do "Empire State" e a engenharia nacional possuia profissionais como Machado da Costa, que na ferrovia Curitiba-Paranaguá, realizava obras de manutenção, reparaçāo e melhorais nos viadutos da Serra do Mar que até hoje surpreendem pelo arrojo e pela sensibilidade estrutural empregada.

Entretanto, mais uma vez copiando a Europa, a nova geração de arquitetos entusiasmava-se com a "moderna" arquitetura nacional, preocupada mais em se identificar com o talento de um Oscar Niemeyer, ou com o próprio Le Corbusier, do que em se aventurar na arquitetura com aço.

Como explicar o fato de que notáveis arquitetos, de um dos períodos mais criativos e produtivos da arquitetura brasileira, tenham ignorado totalmente o aço como expressão arquitetônica?

Possivelmente, porque a tradição mediterrânea e romanesca, tão bem personificada na obra de Le Corbusier, tenha encontrado melhor acolhida e melhor assimilação pelos arquitetos cariocas, de raízes étnicas portuguesas e pelos arquitetos paulistas, italos-árabe-israelenses, que relutaram em aceitar a arquitetura do aço, anglo-saxo-germânica, protestante, intelectualizada, lógica e disciplinada de um Gropius, Mies van der Rohe ou Saarinem.

A tentativa de justificar tal aleamento, remetendo a culpa para a falta de perfis de aço no mercado, não é verdadeira, pois durante o Estado Novo foi instituído o Plano Siderúrgico Nacional, que redundou na instalação de três usinas de grande porte, sendo a primeira em Volta Redonda, a Companhia Siderúrgica Nacional - CSN - que começou a operar em 1946; a segunda em São Paủlo, atual COSIPA, que só começou a operar em 1960 e a última, em Minas Gerais, atual USIMINAS, que também começou as suas operações na década de 60.

Durante os anos 50 ocorreu uma elevada taxa de industrialização no país, conseguida devida a uma atuação mais intensa do Estado. 
Esta atuação estatal buscava a substituição de produtos importados, que durante a segunda guerra tiveram suas importações suspensas, a equilibrar a balança de pagamentos mas, principalmente a incentivar a consolidação da indústria de base, gerando deste modo as condições necessárias para transformar o pais de agrícola em industrial.

A indústria siderúrgica foi, durante este período, capaz de atender a toda a demanda, gerando inclusive um excedente que, por falta de produtos e de tradição não havia formado mercado exportador, precisava ter garantido o seu consumo, mesmo que no mercado interno.

Para viabilizar este consumo e ao mesmo tempo, criar uma infraestrutura de apoio a um ramo da engenharia que estava relegado ao esquecimento, foi criada em 1953 a FEM - Fábrica de Estruturas Metálicas, subdisiária da CSN de Volta Redonda, que deu início ao ciclo completo de produção de estruturas de aço, desde o cálculo, o detalhamento, a fabricação e até a montagem.

A FEM também foi a pioneira, no Brasil, na construção de edifícios de andares múltiplos e responsável pelas maiores e melhores obras de aço do país, como edifícios industriais, pontes, viadutos e instalações agrícolas.

Além das obras, a FEM ainda formou os melhores profissionais do setor, cujo embrião se originou do engenheiro José de Moura Villas Boas e do projetista Roosevelt de Carvalho.

Até o final dos anos 50, a FEM fabricou e montou perto de 16.000 toneladas de estruturas distribuidas em diversos edificios de andares múltiplos, a maioria calculada por Paulo Fragoso, engenheiro dos mais sensiveis a todos os movimentos de renovação e de inovação que ocorreram no país, tendo inclusive calculado a cobertura pênsil do pavilhão de São Cristóvão, no Rio de Janeiro, considerada uma das maiores do mundo até os dias de hoje.

Embora este esforço concentrado tenha produzido um impulso poderoso, que possibilitou futuros desdobramentos, quando os profissionais formados na FEM passaram a colaborar com outras empresas, na arquitetura não foram sentidas perturbações no caminho da "moderna" arquitetura brasileira:

$\dot{A}$ exceção de alguns poucos profissionais, que utilizando a estrutura industrial montada na FEM, realizaram projetos pioneiros em edifícios de andares múltiplos, observa-se que, na sua maioria, eram quase que os mesmos que fizeram a incrivel semana de arte de 1922. 
Dentre os edifícios construidos nesta época merecem destaque, conforme DIAS [ 16 ]:

Garagem América - São Paulo Arqo. - Rino Levi

Engo. - Paulo Fragoso

Fabricação: FEM - 1954 - Consumo de 896 toneladas de aço, com 16 andares, média de $59 \mathrm{~kg}$ de aço/m².

Palácio do Comércio - São Paulo Arqo. - Kerngold

Engo. - Paulo Fragoso

Fabricação: FEM - 1955 - Consumo de 1361 toneladas de aço, com 20 andares, média de $60 \mathrm{~kg}$ de aço/m².

Garagem do Jóckey Clube - Rio de Janeiro - Arqo.Lúcio Costa

Engo. - Paulo Fragoso

Fabricação: FEM -1956 - Consumo de 2003 toneladas de aço, com 13 andares, média de $70 \mathrm{~kg}$ de aço/m².

Avenida Central - Rio de Janeiro - Arqo. - Henrique Mindlin Engo. - Paulo Fragoso

Fabricação: FEM - 1957 - Consumo de 5620 toneladas de aço, com 34 andares, média de $90 \mathrm{~kg}$ de aço/m².

Montepio dos Empregados Municipais - Rio de Janeiro

$$
\begin{aligned}
& \text { Arqo.- Affonso Eduardo Reidy } \\
& \text { Engo. - Paulo Fragoso }
\end{aligned}
$$

Fabricaçāo: FEM - 1957 - Consumo de 1218 toneladas de aço, com 23 andares, média de $71 \mathrm{~kg}$ de aço/m².

Santa Cruz - Porto Alegre - Arqo. - Raul Luna

$$
\text { Engo. - Paulo Fragoso }
$$

Fabricação: FEM - 1958 - Consumo de 1900 toneladas de aço, com 34 andares, média de $79 \mathrm{~kg}$ de aço/ $\mathrm{m}^{2}$

Escritório Central da CSN - Volta Redonda - Arqo. - Glauco Oliveira Engo. - José de Moura Vilas Boas Fabricação: FEM - 1958 - Consumo de 2500 toneladas de aço, com 18 andares, média de $70 \mathrm{~kg}$ de aço/m². 
Por esta época, anos 50, chegava ao Estado de São Paulo o engenheiro Herman Schulte, imigrante russo, com notável experiência em construções de aço que, através da Universidade Mackenzie e da Escola de Engenharia de São Carlos, da USP, criou dois centros de formação de profissionais especializados, que somados ao núcleo pioneiro de Volta Redonda, formaram a estrutura que implantou e consolidou a engenharia com aço em nosso pais.

Esta era, no campo da engenharia, a estrutura existente nos anos 60 , que foi suficientemente capaz de participar da implantação do plano Siderúrgico Nacional, construindo a COSIPA e a USIMINAS, expandido a CSN e a Belgo-Mineira, permitindo assim a instalação das indústrias automobilística e naval, grandes consumidoras dos produtos siderúrgicos.

Quando do desenvolvimento dos projetos siderúrgicos, foi criada em 1961, a COBRAPI - Companhia Brasileira de Projetos Industriais, também subsidiária da CSN, em Volta Redonda, que até a sua privatização, ocorrida em 1990, projetou diversas fases das usinas de TUBARÃO, COSIGUA, COSIPA, USIMINAS, CSN, USIBA, COSINOR, SIDERAMA, AÇOMINAS, ACESITA, as instalações portuárias da COSIPA em São Paulo, da CSN no Rio de Janeiro e da CVRD em Vitória, sendo pioneira, junto com a FEM, do projeto, construção e instalação de plataformas marítimas destinadas à exploração de petróleo, desenvolvidas para a Petrobrás.

A partir destes núcleos pioneiros, foi difundida e aprimorada a tecnologia das construções com aço, que possibilitou a exportação de produtos semi-acabados como chapas, trilhos e perfis e acabados como diversas estruturas metálicas, destinadas a construções industriais e residenciais, uma vez que estes produtos possuem niveis internacionais de qualidade.

Devem ser citados, por uma questão de justiça histórica, os engenheiros Carlos Vargas e Ivan Lippi Rodrigues, que tanto trabalharam para a absorção e o domínio desta tecnologia, sendo os pioneiro no cálculo de plataformas maritimas, chegando, no caso do Engo. Vargas, a ser detentor de patente mundial na área de transportadores tubulares.

Entretanto, apesar dos esforços no campo da engenharia, a arquitetura permaneceu desinteressada das construçōes com aço, a menos das exceções já citadas, sendo sua produção direcionada totalmente para o concreto armado, criando mais uma geração de profissionais voltados exclusivamente a tentar se igualar aos gênios de Niemeyer e Corbusier. 
No final dos anos 80 ocorreu um pequeno envolvimento da arquitetura com os edificios em aço, em Belo Horizonte, onde foram construídos diversos prédios residenciais, que não ultrapassam nem em área construída, nem em número de pavimentos, as obras pioneiras realizadas 30 anos antes.

- Observando, por exemplo, o edifício do Escritório Central da CSN, construído em 1958, em Volta Redonda, encontram-se painéis préfabricados nas paredes externas, que comportam os caixilhos, formados por vidros duplos com uma veneziana intermediária.

A circulação de ar entre os vidros, é assegurada por uma série de furos convenientemente dispostos e que regulam o fluxo de ar. $O$ acionamento das venezianas é feito externamente ao caixilho, que possui ainda um mecanismo que permite a fixação da sua abertura em diversas posições e o seu pivotamento, para limpeza externa.

Analisando agora as últimas construções em edifícios de andares múltiplos, realizadas em Belo Horizonte, ou no edifício construido em Alphaville e em alguns outros em construção na cidade de São Paulo, encontra-se a maioria das paredes, tanto as internas como as externas, construídas com tijolos, exatamente como nos edifícios "Leiter l" e "Tacoma" e muitos outros, construídos há aproximadamente 100 anos em Chicago. 


\section{2- ASPECTOS CONSTRUTIVOS}

\section{1- OS SISTEMAS ESTRUTURAIS}

Os construtores da antiguidade possuiam diversos conhecimentos, possivelmente empíricos, de como dispor os elementos estruturais em uma construção, afim de obter a estabilidade necessária.

Nas construçōes com grandes dimensōes utilizaram a pedra, nas menores o tijolo ou a madeira.

Com a pedra e o tijolo construiram muros, paredes, pilares, pisos e alicerces, que possuiam a estabilidade necessária, quase que tão somente, devido ao peso próprio destes materiais.

Para as pontes e aquedutos empregaram o arco, que com a devida forma geométrica ficava, quase que exclusivamente, solicitado por esforços de compressão, o que aumentava sua estabilidade.

Os sistemas que empregaram a madeira, seguiram de perto os sistemas em alvenaria, a menos dos casos em que essa precisava de uma estrutura suporte, como em paredes e em telhados, onde a estabilidade era assegurada por barras inclinadas, convenientemente dispostas.

Acredita-se ser este o primeiro sistema de contraventamento desenvolvido e que permitia montar toda a estrutura de um andar, antes de completar a execução das paredes ou do telhado, com tábuas ou com outro material de enchimento.

Este é o sistema construtivo, ainda utilizado em pequenas residências nos estados do sul e do norte do nosso país, onde a madeira ainda é abundante. •

Procurando disciplinar a arte de construir foram escritos, durante 0 renascimento europeu, alguns textos que na sua maioria resultaram de traduções ou compilações de outros mais antigos, gregos ou romanos, cuja impressão foi facilitada após o advento da imprensa. 
Destes textos, poucos continham contribuiçōes novas, como os publicados por Palládio ou por Brunelleschi.

A publicação de Palládio, aborda o estudo das estruturas de madeira, dando informaçōes sobre os tipos de tesouras utilizáveis em coberturas e em pontes, vãos recomendados, dimensões das peças, ligações, etc.

Brunelleschi tratou mais do aspecto externo das construções, seu estilo, materiais, ligações e principalmente do aspecto da estabilidade.

Este era o ambiente tecnológico quando da introdução do ferro como elemento construtivo, na forma de barras, que apenas permitiram a substituição da madeira, nos casos onde esta era empregada como elemento estrutural.

Com a verificação das vantagens que o ferro oferecia, como a maior resistência mecânica, a possibilidade de moldar sua forma por martelamento ou refusão e a facilidade para realizar as ligações entre barras, sua utilização aumentou junto com o interesse por este elemento estrutural [ 29 ].

Quando da construção do Palácio de Cristal em 1851, colunas, arcos, vigas e os contraventamentos, foram fabricados em uma oficina e montados no local da obra. As ligações entre estes diversos elementos eram realizadas por meio de encaixes e em pouquíssimos casos por parafusos.

Buscando obter obras mais duradouras e menos susceptiveis ao fogo, foram empregadas colunas e vigas de ferro fundido, embora visando suportar apenas os diversos pisos superpostos, uma vez que as paredes continuavam a ser auto-portantes, ou seja, não descarregavam seu peso nas estruturas de ferro.

A primeira exceção a esta maneira de construir ocorreu no edifício de uma fábrica de chocolate, construido sobre os quatro pilares de uma antiga ponte sobre o rio Marne, nos arredores de Paris [ 22 ].

Este edificio, construido em 1872, por Jules Saunier, a exemplo do que o Palácio de Cristal fizera na sua época, sintetizou o que havia de melhor na tecnologia do ferro e antecipou alguns elementos estruturais que somente seriam utilizados muitos anos depois, na atual arquitetura com aço.

As vigas do "piso possuiam balanços, que recebiam nos seus extremos as colunas laterais, que por sua vez possuiam um rede de diagonais formando planos de contraventamentos nas faces externas. Mas, a inovação principal residia nas paredes que descarregavam seu peso nas vigas que formavam a malha lateral. 
Porém, o sistema estrutural que seria o mais empregado nas construçōes metálicas, surgiu em 1879 no edifício "Leiter I", em Chicago, projetado por Jenney.
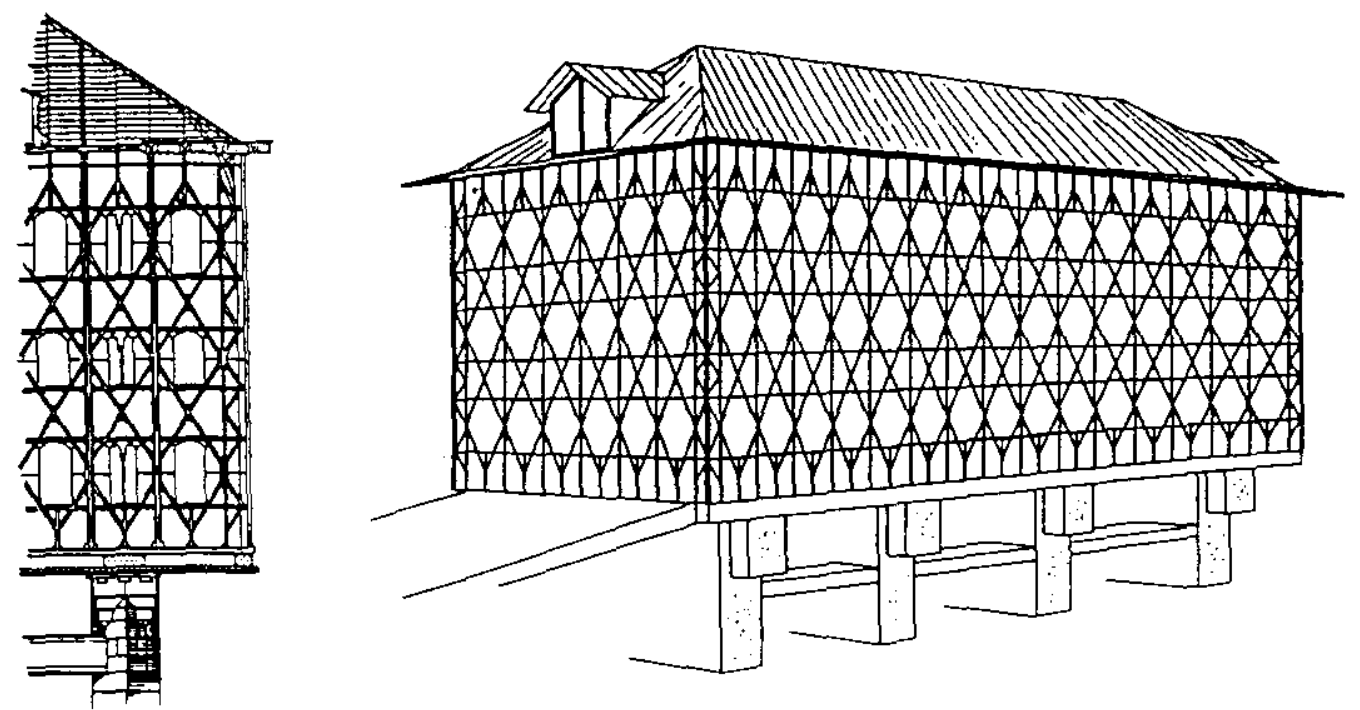

Figura 2.1 - Fábrica de chocolate sobre o rio Marne

Este edifício possuía 7 andares, com vigas e colunas em ferro laminado, unidas por parafusos, dando origem a pórticos múltiplos nas suas faces. As paredes serviam de enchimento aos vãos entre as vigas e as colunas, colaborando na estabilidade global, pois as ligações entre as barras metálicas, realizadas com parafusos comuns, eram bastante flexiveis.

Em 1889, foi construido o edifício "Tacoma", com 14 andares, projetado pelos arquitetos Holabird e Roche, o primeiro a utilizar ligaçōes rebitadas, o que assegurou maior rigidez à estrutura[ 22 ].

A alteração seguinte ocorreu com a laminação de perfís de aço, que substituíram os de ferro. As colunas de ferro com volutas, chanfros e outros tipos de acabamento tornaram-se obsoletas e as estruturas adquiriram as linhas retas, mantidas até os dias atuais.

$\mathrm{Na}$ virada do século já se encontravam publicações com dados estatísticos sobre a ação do fogo em estruturas e descriçōes detalhadas de como proteger a estrutura e seus elementos.

Quanto aos contraventamentos, uma exigência para obter-se uma estrutura realmente eficiente, já constavam de recomendações publicadas em 1890, onde três formas de execuçāo eram sugeridas e que são utilizadas até hoje: 
Estas formas de tornar eficiente uma estrutura, por meio de contraventamentos, preconizadas no final do século passado, são as seguintes:
a- Em diagonal, com perfís de seção circular, que se interceptam.
b- Treliçados, ligados rigidamente aos pilares
c- Aporticados, quando nāo fosse possivel usar as diagonais.

Como pode ser facilmente percebido, estas são as formas mais empregadas até os dias de hoje, para esta finalidade.

O desenvolvimento do concreto armado forneceu inúmeros subsídios aos calculistas de estruturas de aço. Pelo seu natural monolitismo, o concreto exigiu o desenvolvimento de procedimentos de cálculo que levassem em conta a relação espacial, os efeitos da continuidade e do engastamento dos seus elementos, passando-se da análise de estrutura isostáticas para as hiperestáticas.

$O$ desenvolvimentos da viga em seção $T$ foi outro passo importante para assegurar a competitividade do concreto junto às estruturas de aço. $A$ transição da viga $T$ para os pisos nervurados, as lajes armadas em duas direções, as lajes cogumelos e as estruturas aporticadas, representam os estágios que se seguiram e que mantiveram o concreto armado como mais empregado em edifícios de andares múltiplos até o final da segunda guerra.

Os engenheiros que projetavam com aço tinham dificuldades para acompanhar os exemplos dos seus colegas do concreto, com os recursos de construção então disponíveis, essencialmente no aspecto das ligações.

Com o desenvolvimento da solda elétrica, dos parafusos de alta resistência e da viga mista, os engenheiros do aço obtiveram os recursos necessários para retomar sua antiga hegemonia, construindo diversos edifícios no sistema aporticado porém, com as lajes de piso executadas em concreto armado, integradas ao sistema estrutural.

Esta simbiose entre $\circ$ concreto e 0 aço tornou-se marcante e irreversivel após a construção do edifício da "Hartford Insurance Company" em 1961, projetado por Skidmore e Associados. Este edifício introduziu como novidade estrutural o núcleo central, totalmente em concreto armado, destinado a resistir às ações horizontais, dispensando a inclusão de contraventamentos ou de engastes entre seus elementos para absorver estas ações [ 22 ]. 
Junto aos núcleos foram utilizados andares destinados a serviços onde, treliçando as vigas dos dois pisos consecutivos, o sistema estrutural assumiu um comportamento semelhante ao de uma coluna engastada e indeslocável na base e, engastada e deślocável no topo.

Este foi o sistema utilizado nos Edifícios "BHP House", de Melbourne, Austrália, de 1970 e no "Shinjuku Administrative", em Tókio de 1976, projetados por Skidmore e Associados.

Outro sistema estrutural bastante empregado e que derivou do sistema com núcleo, é o de pisos suspensos.

Neste sistema, o núcleo fica responsável também pelas ações verticais, transmitidas por uma treliça de comportamento espacial, posicionada no topo do tubo. As extremidades dos pisos são atirantadas à treliça para aliviar as solicitaçōes nas vigas que formam os andares.

Este sistema foi utilizado nos edifícios do banco de Dublin, Irlanda; nos laboratórios em Heidelberg, Alemanha; no "Alpine Montan Administrative Building et Leuben", Aústria e no "Office Building" , Vancouver, Canadá.

Uma variante deste sistema pode ser encontrado nos edificios Oliveti, Frankfurt e National, Westminster Bank, Londres, que possuem as vigas que formam os pisos engastados no núcleo central.

Dando continuidade à constante evolução nas estruturas de concreto, foi construído o edifício da CBS em Nova lorque, em 1961, mais um projeto de Saarinem coroando sua reação à arquitetura Miesiana.

Neste edifício, os pilares externos são tão próximos que quase não é possivel dizer que exista uma estrutura, parece mais uma parede contínua perfurada por rasgos onde estão encaixadas as janelas. As quatro paredes assim formadas, dão origem a uma estrutura com comportamento estrutural parecido com o de um tubo, de seção quadrada, engastado em um extremo, a base, e livre no outro, o topo.

O edifício possui ainda um núcleo estrutural e pisos nervurados que aumentam a rigidez do conjunto, aproximando ainda mais o comportamento ao do tubo perfeito.

O sistema estrutural em tubo, foi aqui utilizado pela primeira vez, dando origem a uma estrutura de grande rigidez, que tornou possivel a construção de um edifício realmente alto em concreto armado, idéia considerada como utópica até então. 
No edifício do "Civic Center" em Chicago, projetado por C.F.Murphy em colaboração com Skidmore e Associados, foram utilizados pilares em seção cruciforme e em aço de alta resistência, espaçados, devidos a problemas com as fundações, em módulos de $26,5 \times 14,7$ metros. As vigas e os pilares das fachadas foram envolvidos em concreto, e revestido a seguir por chapas de aço cor-ten, ancoradas ao concreto por meio de pinos.

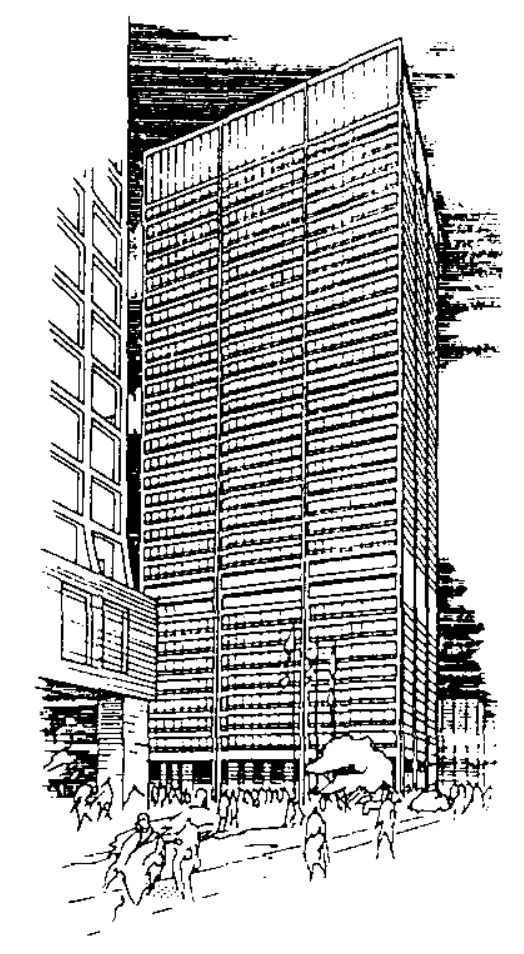

Figura 2.2 - Edifício Civic Center

Garantiu-se, deste modo, um melhor comportamento estrutural, como de uma seção mista, aumentando a rigidez estrutural e consequentemente reduzindo os deslocamentos laterais causados pela ação do vento. A estrutura de aço, sozinha, não resistiria adequadamente a estas forças e por esta razão foi incorporado este sistema híbrido de enrijecimento.

$\mathrm{Na}$ construção com aço, foram feitos avanços significativos ao serem incorporados os sistemas desenvolvidos para o concreto armado, produzindo sistemas mais eficientes que permitiram a construçăo de edifícios com mais 20, 40 e 60 andares que os correspondentes em concreto armado. 
Entretanto, o clássico sistema de contraventamentos nas fachadas, utilizados na fábrica de chocolate, é que permitiu a construção dos edifícios da IBM em Pittsburg, do edifício da Alcoa em São Francisco e do "John Hancock Center" em Chicago.

Interessante no "Hancock Center" é a possibilidade de remover os pisos e realocá-los, de acordo com as necessidades, devido às ligações simples parafusadas das vigas dos pisos e às colunas internas que recebem apenas forças verticais, uma vez que as horizontais são totalmente resistidas pelo "tubo treliçado externo".
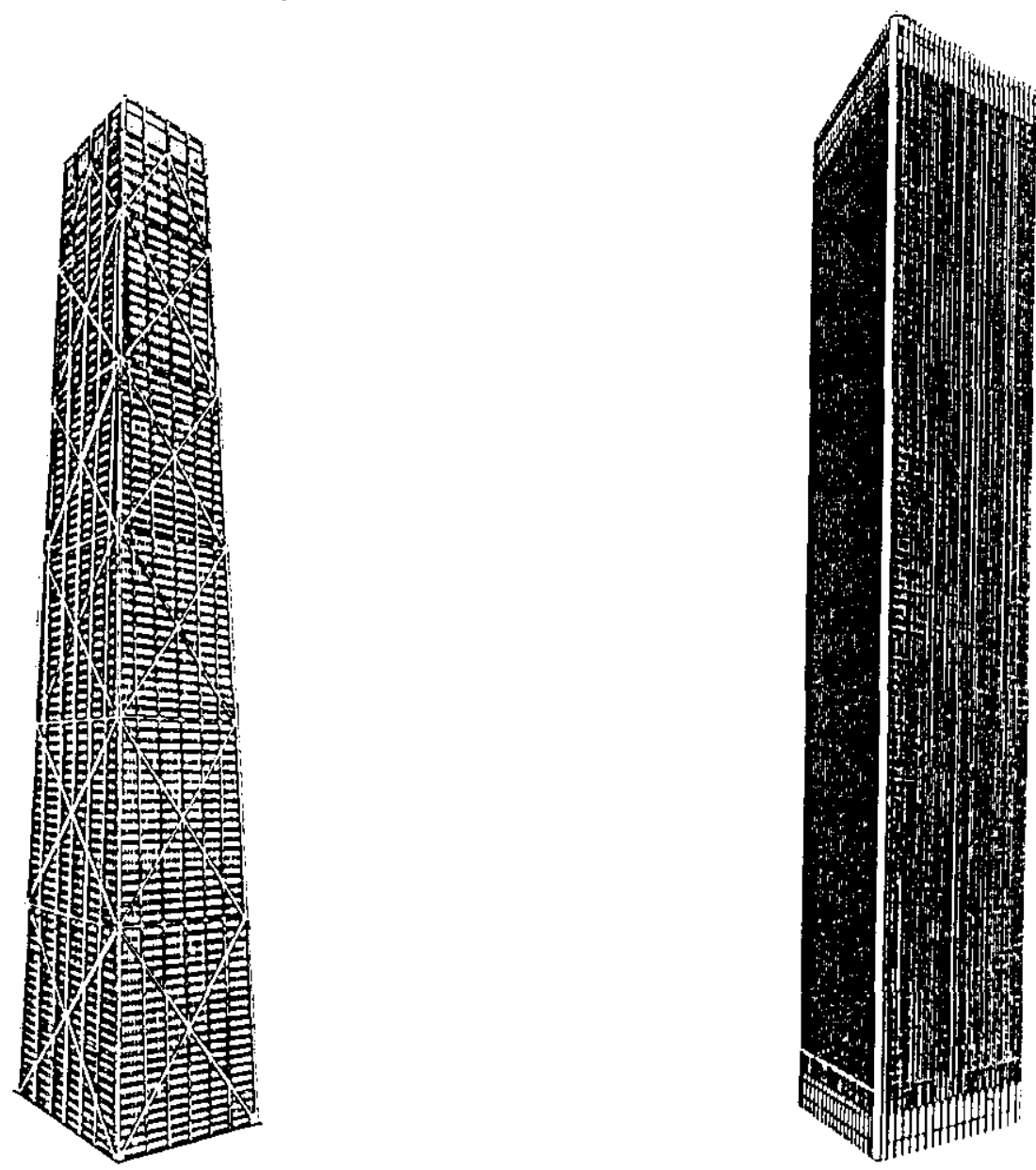

Figura 2.3 - Edifícios " John Hancock "e " World Trade Center "

No "World Trade Center" em Nova lorque, cuja construção começou em 1966, foi utilizado o sistema tubular e como no "Hancock Center" as colunas internas só recebem forças verticais. As paredes externas transformam-se em vastas vigas "Virendeel " pelas ligações rígidas das vigas que formam os painéis das janelas aos pilares, que são de seçăo tubular. 
Simultâneo com este edifício foi construído a torre da "Sears", projetado por B. Graham, empregando o sistema estrutural tubular, formado por um conjunto de 9 seções ocas, quadradas, com 22,8 metros de lado e com cinco vãos de pilares.

As seções que formam o conjunto são escalonadas, com alturas diferentes, remetendo a um projeto de Sullivan, de 1891, com uma configuração bastante semelhante de 9 prismas, de seção quadrada, escalonadas em andares recuados [ 22 ].

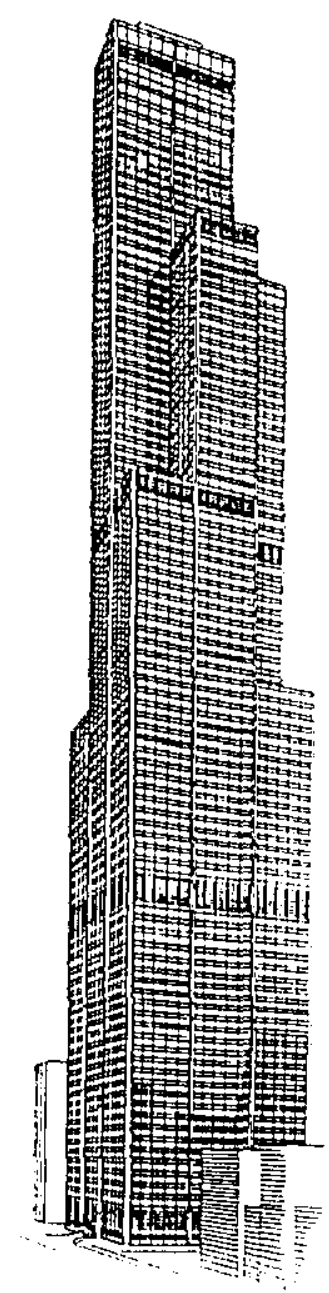

Figura 2.4 - Edifício da Sears

Embora o sistema tubular tenha sido desenvolvido para os edifícios em concreto armado, a sua introdução nos edifícios de aço foi feita por quem o desenvolveu, no caso o engenheiro Fazlur R. Khan, sócio da Skidmore e Associados e professor do IIT. 


\section{2- A RACIONALIZAÇÃO NAS ESTRUTURAS DE AÇO}

Desde o início da utilização das estruturas de aço, os projetistas descobriram que quanto mais moduladas e racionalizadas elas fossem concebidas, menor seria o seu custo final, tanto pela economia de escala na fabricação de seus componentes, como na seriação da estocagem, manuseio e montagem destes componentes, o que reduz o prazo necessário para a execução total da obra.

Estas vantagens, que a pré-fabricação proporciona, podem induzir ao erro de considerar as estruturas de aço como mais econômicas do que qualquer outra opção estrutural.

Entretanto, para fazer uma comparação correta entre diferentes estruturas, por exemplo, uma de aço e outra de concreto, torna-se necessário o desenvolvimento e a otimização do projeto, em todos os seus níveis para as duas especialidades, quando só então deve ser executado o levantamento dos custos de cada uma das opçōes construtivas.

Cabe também alertar, que uma estrutura de aço é, como regra geral, uma alternativa viável, quando alguns dos requisitos listados a seguir podem ser atendidos [ 29 ]:
a - Grandes vãos nos pisos
b - Grande altura da construção
c - Flexibilidade no "layout" interno
d - Possibilidade de ampliaçōes futuras
e - Solo de baixa capacidade suporte
f - Instalação de complexos sistemas de utilidades
g - Prazo de construção reduzido
$\mathrm{h}$ - Montagem sob condições atmosféricas adversas
i - Montagem em locais com pouca área para armazenamento.

Evidentemente, o grau de viabilidade cresce com a quantidade de itens atendidos. Esta viabilidade também está ligada ao consumo de aço previsto para a execução da obra. Este consumo costuma ser expresso pela razão, entre o peso total do aço e a área dos pisos $\left(\mathrm{kg} / \mathrm{m}^{2}\right)$, ou do peso total pelo volume da construção $\left(\mathrm{kg} / \mathrm{m}^{3}\right)$. Valores menores nestas razões costumam levar a construções mais econômicas. 
Diversos fatores contribuem para esta redução, entre os quais podem ser citados:

1 - Sistema estrutural a emprégar

2 - Tipos e arranjos dos contraventamentos, núcleos, paredes e demais elementos de enrijecimento da estrutura

3 - Arranjo, espaçamento e tipo da seçāo dos pilares

4 - Arranjo das vigas dos pisos

5 - Elementos de fechamento, como pisos, paredes, coberturas, circulação vertical, etc.

Sobre estes itens podem ser acrescentadas mais algumas observaçōes, como por exemplo, a escolha do sistema estrutural, que está ligada a fatores como as dimensões da edificação, imposições de arquitetura ou da ocupação da construção.

Para as construçōes com no máximo 4 andares, o sistema estrutural mais empregado é o aporticado. Como estas construçōes, na maioria dos casos, não possuem elevadores, torna-se difícil criar núcleos rígidos, quer com contraventamentos, quer com paredes de concreto.

Portanto, neste caso pode ser empregado o pórtico múltiplo deslocável, cuja estabilidade é assegurada pelo engastamento entre as vigas e os pilares.

Entretanto, se for possivel criar um ou mais núcleos rígidos, ou nas caixas das escadas ou em alguma outra circulação vertical, poderão ser aliviados os engastes dos pórticos, o que representará uma sensivel economia em parafusos, chapas e soldas, que seriam aplicados nestes locais.

Outra economia sensivel, resultará dos pilares, que ficarão submetidos apenas à compressão, pois como se sabe, a solicitação critica para estes elementos costuma ser a flexo-compressão, principalmente quando no plano de menor inércia.

Para construções mais altas, ou que possuam elevadores e que consequentemente possuirão um núcleo rígido nestes locais, a solução estrutural óbvia é escorar os pórticos nestes núcleos.

Entretanto, estes núcleos costumam necessitar de fundaçōes mais complicadas e exigem taxas de armaduras mais altas, devido ao acréscimo de solicitações. 
Também deve ser lembrado que os núcleos em concreto, exigem mais atenção no cronograma da obra e embora diligentemente executados não atingem a precisão de fabricação das estruturas de aço. Devido a este fato, deve ser dado um cuidado especial às ligaçōes do núcleo com a estrutura de aço.

Com alturas significativas, ou com grandes dimensões em planta, podem ser necessários outros sistemas de enrijecimento. Nestes casos, a solução que menos interfere com a ocupação interna do edifício, é a colocação de contraventamentos, ou de engastes, nos planos dos pilares externos.

Em qualquer dos casos citados, deve ser lembrado que um contraventamento em aço é, na grande maioria dos projetos, a solução mais econômica dentre todas as enumeradas, para dar estabilidade a uma construção.

Como contraventamentos em uma fachada interferem, e em muito, no aspecto externo da construção, criando um efeito fora do comum, a solução mais empregada acaba sendo a de engastar as vigas aos pilares.

A disposição dos pilares, assim como a sua forma, também podem afetar o consumo de aço em uma construção. Como regra geral, os pilares devem ser localizados em interseções de vigas, formando uma malha, de preferência retangular, mais indicada que a quadrada, evitando assim as lajes armadas em duas direçōes, que oneram as armaduras e as soluçōes pré-fabricadas.

Os pilares da fachada com pequeno espaçamento entre si, são mais indicados uma vez que possuirão uma área relativamente menor, podendo também receber diretamente 0 fechamento, eliminando a necessidade de montantes ou estruturas especiais.

Quanto à sua forma, devem ser evitadas as seções fechadas, caixões ou tubulares, pelas dificuldades que apresentam nas ligaçōes e para a inspeção das soldas de composição, embora possuam melhor comportamento estrutural. A seção mais empregada é em "I", laminada ou soldada.

Quando os pisos forem formados por vigas de aço, o espaçamento entre pilares não deve ser inferior a 6 metros, obtendo-se uma otimização para vãos da ordem de 8 a 10 metros.

Com treliças, no lugar das vigas de piso e com a altura de um pé direito, é possivel vencer economicamente vãos de 30 a 60 metros. 
Para garantir a estabilidade lateral das vigas e das treliças do piso, algumas vezes torna-se necessário a colocação de contraventamentos horizontais, mesmo que apenas durante a construção.

Esta estabilidade costuma ser assegurada, durante a vida útil da estrutura, pelo sistema estrutural empregado no piso, sendo a laje de concreto, pré-fabricada ou fundida no local, o mais empregado dentre os existentes.

A incorporação do concreto da laje à viga de aço, tem apresentado resultados estruturais e econômicos altamente satisfatórios, podendo-se afirmar que esta solução foi empregada na quase totalidade das construções atuais.

Entretanto, esta solução estrutural, conhecida entre nós como viga mista, pode conduzir a pisos bastante flexíveis que, dependendo da natureza das ações de ocupação, podem apresentar vibrações acima do nível tolerado ou recomendado [ 31 ].

Uma forma de amortecer, ou apenas de reduzir estas vibrações, consiste na escolha dos fechamentos verticais, tanto externos como internos.

Estes fechamentos, assim como os forros ou demais acabamentos, devem ser os mais pré-fabricados possivel, para poderem acompanhar o ritmo de montagem da estrutura.

Aqui reside um dos grandes problemas da construção de edifícios entre nós, pois os fechamentos em alvenaria, por várias razões, ainda são mais baratos que outros sistemas industrializados.

Porém, embora baratos, os fechamentos em alvenaria são mais pesados, aumentando assim as ações verticais na estrutura $e$ consequentemente nas fundações.

Os fechamentos pré-fabricados, em aço ou alumínio, com vidro ou pedra como enchimento, possuem menor peso próprio e precisão dimensional mais compativel com a obtida nas estruturas de aço.

Além da economia que pode ser obtida com a otimização do consumo de aço em uma estrutura, como os já enumerados, deve-se ter em conta, por ocasião do projeto, alguns outros fatores como a relação custo do material e de mão de obra e os custos de manutenções futuras, que usualmente não perturbam os nossos projetistas.

Os materiais, como regra geral para a redução os custos, devem ser escolhidos em função do uso da estrutura. 
Entre os diversos tipos de aço, o mais econômico é o aço carbono, de média resistência, disponível na forma de laminados planos, chapas, placas e barras.

Lamentavelmente, as siderúrgicas nacionais ainda não produzem os perfís laminados de abas paralelas, ideais para a utilização em edifícios de andares múltiplos, devendo os projetistas lançarem mão de perfís soldados.

Embora de custo final superior aos laminados, os perfís soldados permitem uma otimização extrema da seção, que possui como única limitação a espessura das chapas que a compõem, uma vez que as larguras ficam totalmente a critério do calculista.

Para os parafusos, cabe observar que os comuns são mais baratos que os de alta resistência porém, ligações feitas com estes em geral resultam mais econômicas, quando a maior resistência pode conduzir a um número menor de parafusos e consequentemente a chapas de nó com menores dimensões.

Entretanto, nas ligações a economia nem sempre pode ser representada pela economia aparente do aço empregado, mas sim pelo custo da mão de obra utilizada na fabricação e na montagem.

Os parâmetros que mais influenciam o consumo de mão de obra em uma ligação são [ 11 ]:

a - Tipo da ligação, se flexível, rígida ou semi-rígida.

. Quanto mais rígidas, mais exigem em mão de obra.

b - Configuração geométrica

. Evitar os recortes, quer em chapas, vigas, etc.

c - O grau de padronização.

. Usar, no máximo, dois tipos de parafusos: os comuns ASTM A-307 e os de alta reistência ASTM A-325.

- Usar um só diâmetro e um só comprimento para todos os parafusos.

- Não usar roscas fora do plano de cisalhamento, pois exigem atenção na montagem e encarecem a fabricação do parafuso.

- Usar um só controle de aperto, e se possível o do giro da porca, que independe da calibração dos equipamentos. O ideal é não usar ligações por atrito, só por contato. 
d - O tipo de junta e dimensão das soldas.

- Usar só soldas de filete e na menor dimensão compatível com as espessuras das chapas.

e - Procurar evitar usinagem de superfícies, alargamento ou ajustes de furos, e soldas de campo.

As observações anteriores justificam-se uma vez que em uma estrutura de aço, o custo do material costuma ser da ordem de 80 a $90 \%$ do custo da mão de obra, enquanto que nas ligações o custo da mão de obra pode chegar a $90 \%$ do custo total.

Portanto, uma estrutura que explore ao máximo a resistência do material e reduza o peso a um mínimo, pode resultar mais cara que uma menos sofisticada, porém de fabricação mais simples e padronizada.

Outro item importante é o custo da montagem, que costuma ser mais alto que 0 da fabricação, sendo que, ao envolver 0 uso de equipamentos como gruas, guindastes ou andaimes, esta diferença torna-se ainda maior.

Como regra geral, costuma-se estimar que este custo situe-se entre uma a uma vez e meia o custo do aço a ser consumido na estrutura. Portanto, estimado o peso total do aço a ser empregado, multiplica-se este valor por 2,0 a 2,5 obtendo-se o provável custo total da estrutura, incluindo a mão de obra da montagem e da fabricação.

Como o preço do aço varia muito pouco de um país para outro, obtém-se assim um valor quase que internacional para a obra, onde o custo do material deve ficar abaixo de US $\$ 1,00$ por quilo e o da estrutura pronta não deve exceder a US $\$ 2,50$ por quilo, lembrando que nos dias atuais (agosto de 1995) a relação entre o dólar americano e o real é quase igual à unidade $(R \$ 1,00=U S \$ 0,95)$.

O consumo ou o custo de outros materiais aplicados às estruturas de aço também podem ser relacionados ao custo global da estrutura. Dois componentes comuns à maioria dos projetos, são o sistema de proteção contra incêndios e o revestimento contra a corrosão, que sob o ponto de vista econômico não devem ser analisados em separado.

Nos elementos estruturais situados no interior do edifício, e protegidos por revestimentos que impeçam o contato com a umidade, geralmente é suficiente uma única camada de "primer" para a sua proteção. 
Nos elementos externos ou naqueles com possibilidade de contato com a umidade, devem ser aplicadas 2 demãos de "primer" e duas de acabamento, precedidas de limpeza mecânica ou química ou então por jateamento de toda a superfície.

Nos elementos com proteção contra incêndio, quando esta fica afastada da superfície, basta aplicar só uma demão de "primer" com a respectiva limpeza prévia.

Quando esta proteção é aderente à superfície apenas o jateamento é suficiente, quando a proteção é executada em concreto, acompanhando ou não a seção do perfil, até o jateamento pode ser dispensado e substituído por limpeza com escovas mecânicas.

O custo de cada um destes tratamentos pode ser representado como porcentagem do custo total da estrutura, conforme [ 29 ] ou seja:

Limpeza e preparação da superfície:

- Limpeza da superfície - comercial $1,8 \%$

- Limpeza da superfície - jateamento $2,3 \%$

- Uma demão de "primer"- 40 micra $2,4 \%$

- Duas demãos de "primer"-80 micra $4.6 \%$

Pintura de acabamento:

Emulsão alquídica ( esmalte sintético )

- Uma demão de acabamento ( 40 micra ) $\quad 2,5 \%$

- Duas demãos de acabamento ( 80 micra) 4,9\%

Base epóxica

- Uma demão de acabamento ( 40 micra ) $\quad 3,5 \%$

- Duas demãos de acabamento ( 80 micra ) $\quad 6,2 \%$

Base acrílica

- Uma demão de acabamento ( 40 micra ) 3,8\%

- Duas demãos de acabamento ( 80 micra ) $\quad 6,5 \%$

Borracha clorada

- Uma demão de acabamento ( 40 micra ) 2,8\%

- Duas demãos de acabamento ( 80 micra ) $\quad 5,1 \%$ 
Lembrando que o custo da estrutura costuma representar de 10 a $15 \%$ do custo total da obra e considerando que a maioria, senão a totalidade, dos elementos estruturais fica interno à edificação ou aos revestimentos de proteção contra incêndios, comportando quando muito a limpeza da superfície e uma camada de "primer", conclui-se que o custo final de proteção contra a corrosão, em um edifício de andares múltiplos, pode ficar situada entre 0,1 a 1,2\% do custo total do edifício.

\subsection{PROTEÇÃO CONTRA FOGO}

Nas construções antigas as preocupações com a possibilidade de irromper algum incêndio, no interior ou em construções vizinhas, podiam ficar restritas a proteger seus ocupantes, prevendo caminhos para removêlos, e os meios disponíveis para delimitar a catástrofe, impedindo-a de se alastrar.

Até esta época, meados do século 18, as construçōes empregavam grandes quantidades de madeira nos seus interiores, na forma de vigas, telhados, pisos, paredes divisórias, móveis, veículos, etc.

Evidentemente, em caso de incêndio as parede de alvenaria tinham alguma chance de ficarem de pé. $O$ incêndio que destruiu Chicago, em 1871, mostrou que muitas vezes nem isso é possivel.

Com o advento do aço e do concreto armado, as construções aumentaram em volume e em número de ocupantes, diminuindo o volume de madeira por unidade de área construída e ao mesmo tempo, estes novos materiais passaram a falsa impressāo de serem imunes, ou pelo menos quase imunes à ação do fogo, gerando um certo descuido nas preocupações com os incêndios.

Realmente es̉tes dois materiais possuem uma resistência ao fogo maior que a da madeira mas, caso o incêndio se alongue por várias horas, esta resistência pode ser vencida, ocorrendo a ruína parcial ou total da construção, que pode aumentar o número de vítimas e mesmo inviabilizar a recuperação da estrutura. 
Vale lembrar que o primeiro Palácio de Cristal, construído em 1851 e a Ponte Britania, de 1846, foram destruídos por incêndios que ocorreram nos seus interiores.

Ao longo deste século, diversos edifícios não suportaram o calor gerado nos incêndios que os acometeram e ruiram durante o sinistro.

Com o aumento sucessivo na altura das construções, que torna difícil, senão impossivel, combater um incêndio nos andares mais altos, obviamente a preocupação maior passou a ser a de permitir a evacuação dos usuários, com um mínimo de ferimentos ou de mortes.

Para que isto seja possivel, a construção não deve apresentar riscos de ruir, total ou parcialmente, durante a ocorrência do incêndio.

Para assegurar estas condições, surgiram diversos regulamentos, decretos e outros instrumentos oficiais, para disciplinar $\circ$ uso, as disposições e mesmo as composições dos materiais de acabamento e de revestimento a serem empregados.

Em paralelo, foram também normalizados os equipamentos de prevenção e de combate a incêndios, assim como os caminhos de fuga, formados por escadas específicas, saídas de emergência e portas cortafogo. Ainda para auxiliar no combate ao incêndio, projetam-se reservatórios auxiliares para água, sob alta pressão, circuítos de tubulação cobrindo toda a área construida, com mangueiras e demais pontos de conexão semeados ao longo de todo o edifício.

Também são previstas fontes de alimentação própria para luzes de emergência, sistemas de exaustão para remoção dos gases e de elevadores e demais acessos para bombeiros e outros combatentes de incèndios. Mas, nada disto importa ou tem valor, se a estrutura não suportar o calor, ou as outras ações provocadas durante a evasão e o combate.

Portanto, apesar dos possíveis prejuízos materiais, representados pelo não reaproveitamento da estrutura, a maior preocupação deve ser a de que esta resista enquanto durar o incêndio ou então, no mínimo até a retirada dos ocupantes do prédio.

Deste modo, para verificar se a estrutura possui esta resistência mínima, é necessário ter uma idéia aproximada do tempo de duração do incêndio que pode eventualmente ocorrer na construção.

De um modo geral, os incêndios começam de maneira tímida, e só quando não dectados, tendem a evoluir, passando a consumir todos os materiais combustiveis, extinguindo-se após. 
Portanto, a duração depende da quantidade de material combustível e logicamente, da presença de oxigênio.

A quantidade de material combustivel pode ser medida pela "energia calorifica" possivel de ser liberada por unidade de área do ambiente, denominando-se esta relação de potencial calorífico.

Por razões históricas, o potencial calorífico de qualquer ambiente costuma ser expresso em quilogramas de madeira por metro quadrado de área, e não em unidades de energia.

Assim, conhecido este potencial pode-se estimar o tempo de duraçāo de um incêndio por meio das diversas expressōes já deduzidas, como por exemplo a de KAWAGOE e SEKINE [ 29 ], que indica:

$$
t=P_{c} \cdot A_{p} / 5,5 \cdot A_{v} h_{v}
$$

onde: $t=$ Tempo de duração do incêndio (minutos)

$P_{\mathrm{C}}=$ Potencial calorifico $\left(\mathrm{kg}\right.$ madeira $\left./ \mathrm{m}^{2}\right)$

$A_{p}=$ Área do pavimento $\left(\mathrm{m}^{2}\right)$

$A_{v}=$ Área das aberturas de ventilaçăo $\left(\mathrm{m}^{2}\right)$

$h_{v}=$ Altura destas aberturas $(m)$

Evidentemente, a maior dificuldade consiste em determinar o valor de $\mathbf{P}_{\mathbf{c}}$ para cada edifício, considerando as possíveis mudanças das características da ocupação e mesmo desta ao longo da vida útil do edifício. Para auxiliar nesta determinação, os códigos internacionais fornecem valores prováveis para este potencial, que variam entre 50 e $400 \mathrm{~kg} / \mathrm{m}^{2}$.

Porém, apenas o conhecimento do tempo provável de duração de um incêndio não permite estabelecer o seu potencial destrutivo. Este potencial pode ser melhor avaliado, caso se registrem as temperaturas que ocorrem no recinto, ao longo do tempo de duração do incêndio.

A curva assim gerada permite obter de maneira simples o grau de severidade do incêndio.

Evidentemente, trabalha-se com a possibilidade de não ocorrência do incêndio, portanto não se conhece a curva a ser usada.

Para resolver este problema, tanto a ISO como a ASTM, desenvolveram curvas padrōes que permitem estimar as temperaturas máximas que devem ocorrer em um incêndio, em função apenas do seu tempo provável de duração. 
Assim, estimada a temperatura máxima, deve-se procurar verificar como esta pode afetar os elementos estruturais. Como se sabe, estes elementos podem sofrer dilataçōes, simétricas ou não, que dependem do número de faces que estejam voltadas para os compartimentos incendiados.

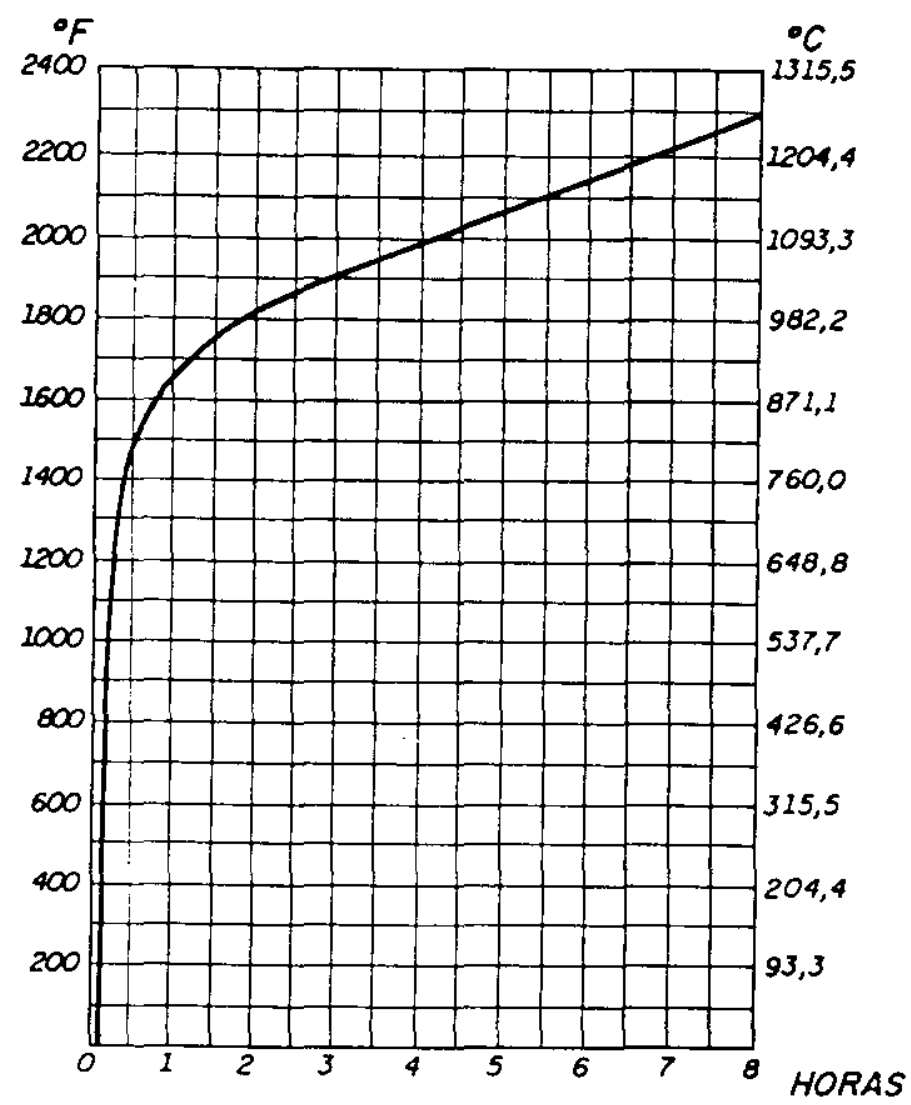

Figura 2.5 - Curva Padrão da ASTM

Colunas e vigas podem ser submetidas a esforços de flexão devido ao aquecimento diferenciado das suas faces, enquanto os contraventamentos, ao serem dilatados, podem ter suas forças axiais aumentadas.

Por outro lado, o simples aumento da temperatura introduz reduções nas propriedades mecânicas dos aços.

Como pode ser observado na curva padrão, as temperaturas máximas atingidas não devem ultrapassar a $1200^{\circ} \mathrm{C}$, enquanto o ponto de fusão dos aços estruturais situa-se em torno de $1500^{\circ} \mathrm{C}$. Logo os elementos de aço não fundem, podem no máximo ter suas propriedades diminuídas.

Uma das propriedade que varia com a temperatura, é a tensão de escoamento, que pode ter esta variação representada como na figura seguinte. 
Esta variação possui dois intervalos distintos, ou seja:

1 - Para T variando de zero a $600^{\circ} \mathrm{C}$

$$
\frac{f_{y, t}}{f_{y}}=1,0+T / 2072 \log (T / 1750)
$$

2 - Para T variando entre $600^{\circ} \mathrm{C}$ e $1000^{\circ} \mathrm{C}$

$$
\frac{f_{y, t}}{f_{y}}=340-0,34 T /(T-240)
$$

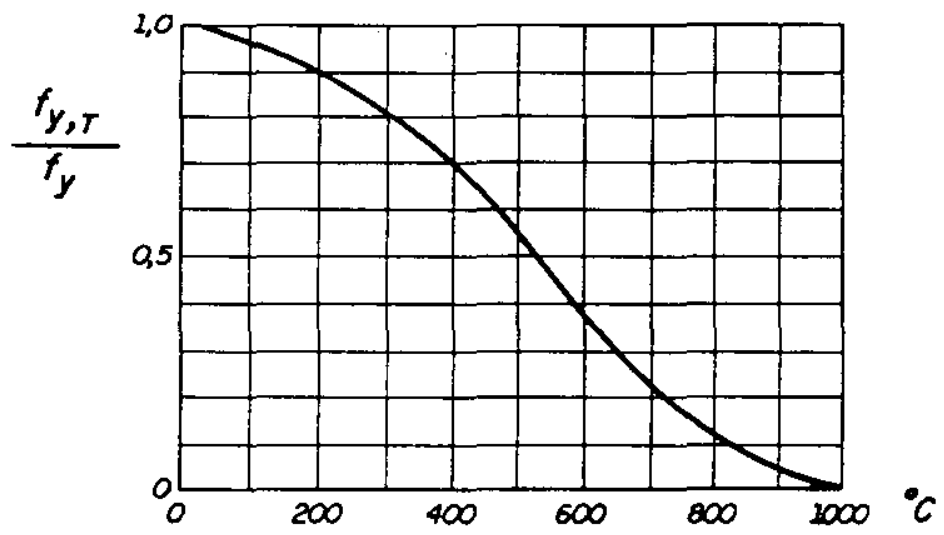

Figura 2.6 - Variação da Tensão Limite de Escoamento

Uma outra variação muito importante ocorre no módulo de elasticidade longitudinal, que pode ser expressa pela equação:

$$
\frac{E_{T}}{E}=1,0+T / 4605 \log (T / 1100)
$$

que, por sua vez, define a curva da próxima figura.

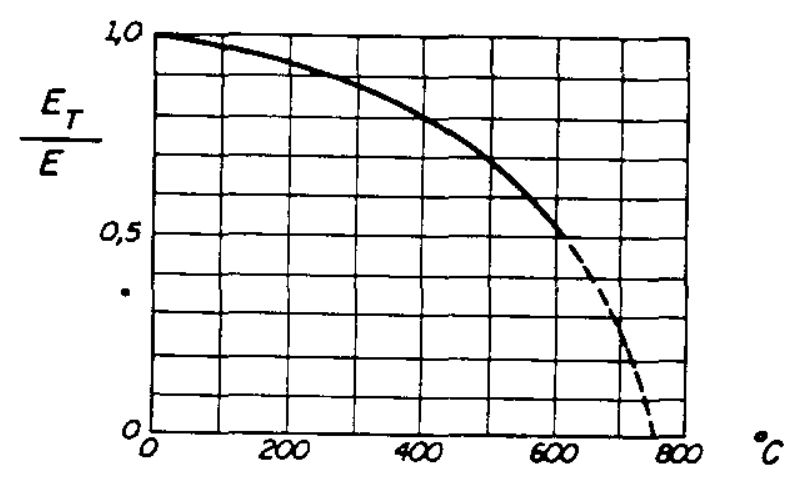

Figura 2.7 - Variação do Módulo de Elasticidade Longitudinal 
Para a verificação da segurança, algumas normas fixam como limite superior o valor de $600^{\circ} \mathrm{C}$, limitando a perda na tensão de escoamento a $60 \%$ e no módulo de elasticidade a $50 \%$.

Entretanto, cabe alertar que a ruptura, ruína ou colapso de um elemento, ou de parte de um elemento, pode não caracterizar o colapso da estrutura, pois as estruturas hiperestáticas redistribuem as solicitaçōes não absorvidas, podendo ter uma certa sobrevida. Por exemplo, em uma viga contínua, o fato de surgirem pontos onde formam-se rótulas plásticas, pode induzi-la a comportar-se como uma série de vigas bi-apoiadas.

É importante frisar que, não costuma ocorrer a destruição da seção do elemento. $O$ aço é um material incombustivel e nas temperaturas verificadas nos incêndios já ocorridos, pode no máximo atingir o estado semi-pastoso em pontos isolados, nunca ao longo de todo o elemento.

No caso dos edifícios de andares múltiplos, que são estruturas altamente hiperestáticas, a formação de algumas rótulas plásticas não costuma dar formação a mecanismos de colapso, apenas a ruínas localizadas.

Os elementos estruturais costumam estar ligados a outros elementos, mesmo não estruturais, de forma que uma parte da quantidade de calor absorvida pode ser transferida para estes elementos, tornando muito difícil a quantificação e a visualização dos efeitos produzidos por um incêndio. No caso das vigas mistas, a transferência de calor que ocorre da viga de aço para a laje de concreto, pode aumentar em até 30 minutos a resistência ao fogo destas vigas que, se contínuas, podem ter esta resistência aumentada para 1 hora [ 29 ].

Portanto, os elementos de aço ao atingirem o limite de escoamento, com tensões mais baixas que as admitidas no projeto, começam a apresentar deformações plásticas e também comportamento plástico, apresentando colapso localizado, lento, gradual e facilmente visivel.

Após $\circ$ incêndio, com o resfriamento, o material readquire as propriedades originais, garantindo segurança para as operaçōes de demolição ou de reconstrução.

A conduta para decidir o destino dos elementos metálicos, pode seguir a regra que melhores resultados apresentou até hoje, que é:

"Se um elemento estiver deformado, substitua-o, se não, pinte-o" uma vez que os aços não costumam esconder nada de suspeito sob a sua superfície externa, após uma exposiçāo a altas temperaturas. 
Porém, uma vez verificado que a duração do incêndio, em função do potencial calorífico contido no ambiente, pode conduzir a temperaturas muito altas, obtidas da curva padrão da ISO ou da ASTM, e que podem levar a estrutura a uma indesejável ruina, total ou parcial, resta ainda o recurso de proteger a estrutura e os seus elementos, impedindo assim os danos provocados pelas altas temperaturas.

Os sistemas de proteção existentes são, na sua grande maioria, formadores de barreiras que impedem o contato do aço com as chamas ou com $\mathrm{o}$ ar aquecido. Para a sua quantificação, ou ainda para a escolha do mais adequado a cada situação, é interessante uma recapitulação sobre os conceitos fundamentais da calorimetria e da termodidâmica.

Lembrando inicialmente que a quantidade de calor absorvida ou emanada por um determinado corpo, pode ser representada pela expressão:

$$
Q=m \cdot c \cdot \Delta_{T}
$$

onde: $Q$ = quantidade de calor (energia)

$\mathrm{m}=$ massa do corpo

$c=$ calor específico do mesmo

$\Delta_{\top}=$ variação de temperatura imposta

Pela lei de Fourier, pode-se representar o fluxo de calor transmitido ou absorvido por condução em um corpo como:

$$
\phi=k \cdot A_{c} \cdot \Delta_{T} / \ell
$$

sendo: $\phi=$ fluxo de calor

$k=$ coeficiente de condutividade térmica

$A_{c}=$ área da seção por onde flui o calor

$\Delta_{\mathrm{T}}=$ diferença de temperatura entre duas seções

$\ell=$ distância entre as duas seções

Para os aços, considerando que a temperatura $(\mathrm{T}$ ) varie entre zero e $750^{\circ} \mathrm{C}$, o coeficiente de condutividade, pode ser determinado pela equação:

$$
k=-0,0283 T+47
$$


sendo que para $\mathrm{T}=600^{\circ} \mathrm{C}$ obtém-se o valor de:

$$
k=30 \mathrm{kcal} / \mathrm{m} \cdot \mathrm{h} \cdot{ }^{\circ} \mathrm{C}
$$

O calor especifico do aço varia com a temperatura, segundo a lei:

$$
c=9,1 \times 10^{-8} \mathrm{~T}^{2}+4,8 \times 10^{-5} \mathrm{~T}+0,113
$$

obtendo-se para $\mathrm{T}=600^{\circ} \mathrm{C}$ :

$$
\mathrm{c}=0,175 \mathrm{kcal} / \mathrm{kg}^{\circ} \mathrm{C}
$$

sendo usual adotar-se nos cálculos o valor de $0,125 \mathrm{kcal} / \mathrm{kg}^{\circ} \mathrm{C}$, considerando-o como constante.

Portanto, conhecidas as constantes do material, observa-se que para um mesmo valor de $\Delta_{T}$, os valores da quantidade e do fluxo de calor, variam em função da massa e da área exposta, respectivamente.

O fluxo pode ser interpretado como a quantidade de calor absorvido, ou liberado, em um determinado intervalo de tempo, ou seja:

$$
\phi=Q / \Delta_{t}
$$

Igualando as duas expressões de fluxo ( 2.3.6) e ( 2.3.9), introduzindo a expressão ( 2.3 .5 ) e colocando em função da massa, encontra-se:

$$
m=k \cdot \Delta_{t} \cdot A / \ell \cdot c
$$

Supondo dois elementos de aço, submetidos às mesmas condições de temperatura e mesmo comprimento exposto ao calor, encontra-se para a relação entre suas massas a mesma relação para as suas áreas, ou seja:

$$
m_{1} / m_{2}=A_{1} / A_{2}
$$

Portanto, caso as massas sejam diferentes entre sí, o corpo de maior massa, deverá ter também uma maior área exposta ao calor, que deve guardar em relação à área menor a mesma razão observada entre as massas. 
No caso dos dois elementos de aço terem massas diferentes, porém áreas expostas iguais, pode-se concluir que o corpo de maior massa esquenta mais lentamente que o mais leve, ou seja, admitindo que $m_{1}>m_{2}$ encontra-se:

$$
m_{1} / m_{2}=\Delta_{t 1} / \Delta_{\mathrm{t} 2}
$$

Portanto, $\Delta_{\mathrm{t} 1}>\Delta_{\mathrm{t} 2}$ que confirma que o corpo de maior massa absorve maior energia calorífica, uma vez que precisa de mais tempo de exposição para manter o mesmo fluxo de calor. Este efeito, comprovado em laboratório, pode ser expresso em função de um coeficiente que relacione a massa e a área exposta, bastando fazer:

$$
F_{f}=P / A_{s}=A_{c} / V_{c}
$$

sendo: $F_{f}=$ fator de forma ou de massividade

$\mathrm{P}=$ perímetro exposto ao calor

$A_{S}=$ área da seção transversal

$A_{C}=$ área exposta ao calor $=P . \ell$

$\mathrm{V}_{\mathrm{c}}=$ volume por unidade de comprimento do perfil $=\mathrm{A}_{\mathrm{s}} \cdot \ell$

$\ell=$ comprimento do perfil

Portanto, duas vigas com mesma área, porém com perimetros expostos ao fogo diferentes, possuirão fatores de forma diferentes.

A figura seguinte representa os resultados de ensaios padronizados, que relacionam o fator de forma e a resistência ao fogo de elementos de aço, até que todos atinjam a temperatura de $550^{\circ} \mathrm{C}$.

Pelo gráfico da figura, é possível determinar a resistência ao fogo de um determinado elemento, uma vez conhecido seu fator de forma e comparar o tempo que ele resiste à exposição ao fogo, com o tempo de duração previsto para um presumível incêndio na estrutura da qual o mesmo faz parte.

Caso a sua resistência ao fogo seja maior, o elemento não precisa de proteção. Caso seja menor, deve-se proteger, ou pelo tempo calculado para a duração do incêndio ou, caso se queira economizar no tipo, ou no volume da proteção, apenas pelo tempo que faltou para que a resistência ao fogo superasse o tempo de duração do incêndio. 
Entretanto, a economia no material de proteção, pode conduzir a um consumo maior de aço, uma vez que os elementos metálicos deverão ser dimensionados considerando apenas $50 \%$ da sua resistência e do seu módulo de elasticidade.

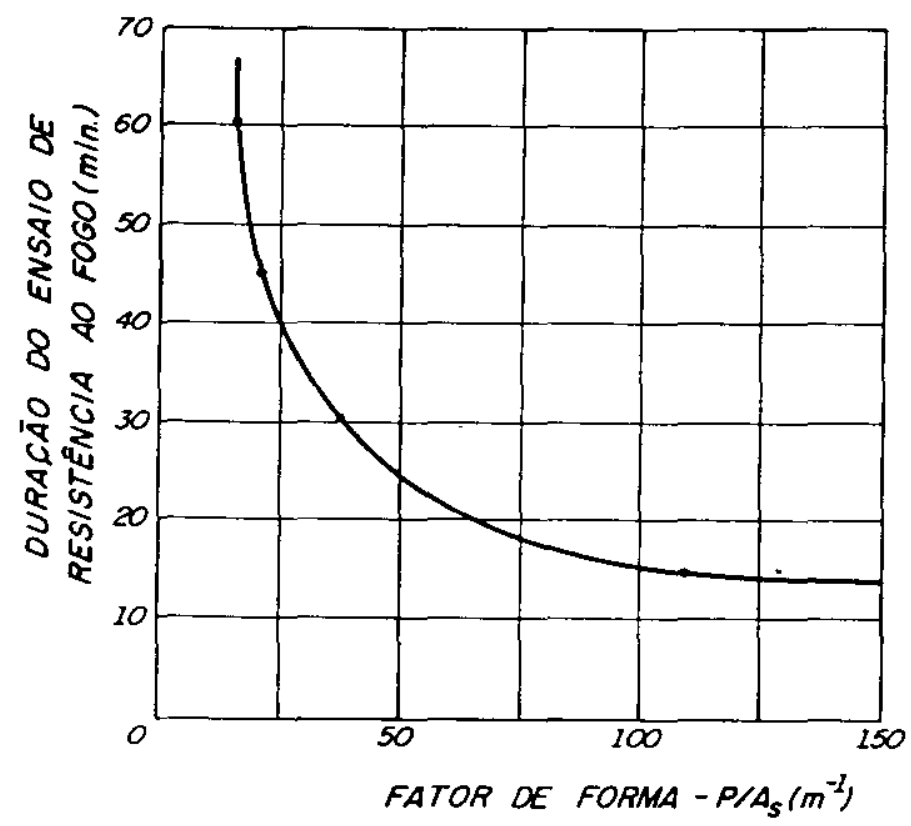

Figura 2.8 - Resistência ao fogo em função do fator de forma

Para a escolha do elemento de proteção deve-se ter em conta, além das propriedades isolantes, algumas outras tais como: baixa densidade, resistência a choque térmicos, coeficiente de dilatação térmica semelhante ao do aço, resistência mecânica, alta coesão sem se fragmentar sob altas temperaturas e durabilidade nas condições normais de temperaturas.

Quanto às formas, os sistemas de proteção podem revestir os perfis metálicos de várias maneiras, como "encamisamento", pinturas intumescentes, barreira química e placas rígidas.

O "encamisamento" pode ser feito com paredes de alvenaria de tijolos cerâmicos, sílico-calcáreos, de concreto celular, ou de concreto simples.

Também podem ser utilizadas argamassas, no contorno do perfil, formadas com agregados comuns, ou então com adição de fibras de amianto, de argila expandida tipo vermiculite ou mesmo gêsso.

Outra forma clássica de proteção consiste em embutir totalmente os perfis em concreto escondendo totalmente a estrutura de aço. 
As pinturas intumescentes são obtidas com a aplicação de tintas especiais, que submetidas a altas temperaturas, aumentam enormemente sua espessura, formando assim a barreira protetora necessária. Apresentam, no entanto, o inconveniente de não resistirem à umidade, sendo indicadas apenas para interiores.

Quanto à proteção química, esta é obtida adicionando-se determinados elementos às argamassas de revestimento, como por exemplo, o oxicloreto de magnésio, que ao ser submetido a altas temperaturas utiliza parte do calor fornecido para calcinar seus componentes, que gera formação de água, a qual consome uma outra parcela de calor para evaporar.

Entretanto, estas argamassas são altamente corrosivas, exigindo pintura protetora antes da sua aplicação.

A proteção por placas rigidas nada mais é do que uma evolução tecnológica da proteção com alvenaria. Estas placas podem ser fabricadas a partir de qualquer um dos materiais isolantes já mencionados.

Devem ser tomados alguns cuidados para que as juntas ou os mecanismos de fixação das placas, não se deteriorem com temperaturas baixas, o que poderia neutralizar a eficácia do sistema.

Apenas como indicação são fornecidas, no quadro seguinte, as espessuras, em milimetros, que cada sistema de proteção necessita ter para resistir a diversos períodos de fogo [ 29 ].

\begin{tabular}{|l|c|c|c|c|}
\hline \multirow{2}{*}{$\begin{array}{c}\text { SISTEMA DE } \\
\text { PROTEÇÃO }\end{array}$} & \multicolumn{4}{|c|}{ PERIOODO RESISTENTE AO FOGO (minutos) } \\
\cline { 2 - 5 } & 240 & 180 & 120 & 60 \\
\hline Concreto fundido no local & 70 & 50 & 40 & 25 \\
\hline Alvenarias de cerâmicos & 100 & 75 & 50 & 50 \\
\hline Alvenarias de concreto & 70 & 50 & 40 & 30 \\
\hline Argamassas inertes & - & - & 60 & 30 \\
\hline Argamassas químicas & 50 & 40 & 35 & 30 \\
\hline Pinturas intumescentes & - & - & - & 3 \\
\hline
\end{tabular}

No caso da utilização da proteção por concreto fundido no local, acompanhando o perímetro do perfil ou então cheio, é conveniente colocar, além da armadura normal, uma tela de malha média, para impedir a fissuração e a desagregação do material. 
Nas alvenarias deve ser prevista a inclusão de estribos e barras longitudinais para impedir a formação de trincas ou rachaduras e sempre revestidas, por argamassas, pedras ou outros materiais incombustiveis.

Nas argamassas devem ser utilizadas telas envolvendo os perfis, com malha não superior a $10 \mathrm{~mm}$, para garantir a aderência e a não desagregação.

Para concluir, cabe lembrar que o decreto lei 10.878 de 7 de fevereiro de 1974, em seu artigo 10, determina que as estruturas de edificaçōes coletivas, residenciais e comerciais, devem apresentar resistência ao fogo de no mínimo 4 horas. 


\section{3- ASPECTOS ESTRUTURAIS}

Após a apresentação da evolução dos edifícios com estrutura de aço, realizada no capitulo anterior, aborda-se a seguir alguns aspectos que influenciam o comportamento estrutural destas construções, independentemente do sistema estrutural a ser adotado.

Embora possam parecer assuntos que devem estar sob o domínio de todo calculista, verifica-se, por exemplo, que os efeitos das ações horizontais, os de segunda ordem, o comportamento dinâmico, ou mesmo a determinação da rigidez relativa das ligações, costumam perturbar alguns profissionais.

Para realizar um estudo mais profundo serão abordados, inicialmente, os aspectos mais gerais das ações a que estas estruturas estão sujeitas $e$ após os aspectos mais complexos, ligados ao comportamento estrutural.

\section{1- AÇÕES PERMANENTES}

Esta costuma ser a primeira ação que todo projetista associa à estrutura que vai projetar, sendo formada pelos pesos próprios dos elementos estruturais e dos demais elementos que compõe a construção.

Nos edifícios de andares múltiplos, além do peso próprio da estrutura, não devem ser esquecidos o peso do forro, das divisórias permanentes ou removíveis, dos revestimentos, dos acabamentos das fachadas, das proteções contra incêndios, dos reservatórios, dos elevadores e seus equipamentos de movimentação, dos equipamentos de condicionamento de ar com seus dutos, das redes de serviço e demais instalações. 
Embora pareça fácil a determinação de todos os valores, quase sempre na fase inicial, costuma-se lançar mão de resultados obtidos em obras anteriores, por não existirem projetos detalhados de todas as utilidades e serviços, podendo ocorrer diferenças de 10 até $30 \%$ entre os valores assumidos inicialmente e os finais, tanto para a estrutura, como para os demais acabamentos e serviços.

Para o peso próprio da estrutura pode-se citar, como regra geral, que para edificios até 20 andares, esta ação costuma situar-se próximo a 60 $\mathrm{kg} / \mathrm{m}^{2}$. Para 20 a 50 andares entre 80 a $120 \mathrm{~kg} / \mathrm{m}^{2}$ e para 50 a 100 andares este valor costuma situar-se próximo de $200 \mathrm{~kg} / \mathrm{m}^{2}$. [11, 29, 42 ].
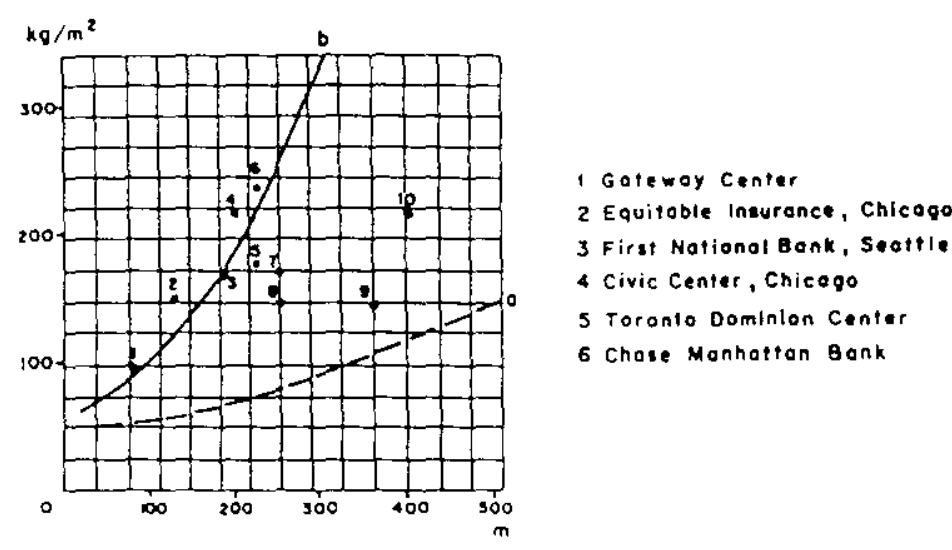

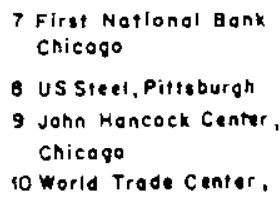

New York

Figura 3.1 - Consumo de aço em função da altura

A figura acima reproduz um gráfico, retirado de HART [ 11 ], que mostra o consumo de aço nos sistemas estruturais destinados a absorverem as ações verticais (curva a ) e naqueles destinados a absorverem as ações horizontais ( curva b ), em função do número de andares. Porém, este assunto ainda será discutido ao longo deste trabalho.

\section{2- AÇÕES VARIÁVEIS}

Uma vez estimado o peso próprio da construção, pode-se discutir outro carregamento importante que possui quase o mesmo grau de incerteza. Trata-se das ações variáveis, também denominadas de sobrecargas, cargas úteis ou de utilização. 
Embora as normas costumem fornecer os valores prováveis de ocorrência, em função das destinações dos compartimentos, cabe ao projetista a dúvida sobre a possibilidade da alteração destes valores, motivada por uma redefinição da ocupação destes compartimentos.

É muito comum em escritórios comerciais a relocação de bibliotecas, que exercem uma ação superior, por exemplo, à prevista para uma sala de reuniões, ou então a troca do material de revestimento do piso, sem esquecer da constante mudança de móveis e divisórias, tanto as "fixas" como as removiveis.

Cabe ao projetista, por ocasião do dimensionamento, levar em conta estas possiveis modificações e aconselhar ao cliente das providências que devem ser adotadas na ocasião.

Quanto aos valores possíveis que as açōes devem assumir, na falta de informaçōes mais precisas, fornecidas pelo cliente ou obtidas de trabalhos ou estudos já realizados, os mesmos podem ser obtidos, na forma de forças com distribuição uniforme por unidade de área, da NBR-6120 [ 5 ].

\section{3- AÇÃO DO VENTO}

Esta era uma ação que, até o final do século passado, não costumava preocupar os construtores, pois até esta época, as únicas construções susceptiveis à esta ação eram as tendas dos povos nômades.

Porém, com o crescimento vertical das construções, tornou-se necessário uma avaliação das forças que o vento pode introduzir em uma edificação. Assim, Gustave Eiffel fez experiências pioneiras, com diversos sólidos, deixados cair de uma altura de $116 \mathrm{~m}$ da torre que leva o seu nome.

Por esta época surgiu o túnel de vento, que permitiu a Wenham, em 1868, medir as principais consequências do vento, 0 arrasto e a sustentação [ 12 ].

De 1871 a 1894, Kernot e Manu, realizaram uma série de pesquisas sobre modelos de cubos, pirâmides, cones, cilindros, esferas, torres, chaminés, telhados, vigas de alma cheia e vigas em treliças. Estes ensaios foram realizados na Universidade de Melbourne, Austrália, e os resultados publicados em 1893 e 1895. 
Na Dinamarca, em 1893, o engenheiro Irminger, da Companhia de Gás da capital, observou que nos dias de vento forte ocorria uma diminuição da pressão do gás. Para entender como o vento produzia esta redução, realizou diversos ensaios que comprovaram a existência de altas sucções nas tampas dos gasômetros. Irminger ensaiou ainda placas, pirâmides, prismas, cones, cilindros, esferas, construções com telhados curvos e em duas águas. Seus resultados foram publicados em 1894.

Os ensaios de Irminger foram realizados com o auxilio de uma chaminé, cuja tiragem chegou a provocar deslocamentos de até $48 \mathrm{~km} / \mathrm{h}$ na base da chaminé, onde eram colocados os modelos.

Eiffel, utilizou um cabo-guia para orientar a queda dos seus modelos, que ao atingirem a velocidade limite, que ocorre no instante em que a resistência do ar equilibra a aceleração da gravidade, impondo assim ao modelo uma velocidade constante, permitiram a determinação da força de arrasto, para cada um dos modelos em estudo.

Francis Herbert Wenham, construiu em 1871, na Inglaterra, o que se acredita ser o primeiro túnel de vento, que a exemplo dos engenhos pioneiros de Eiffel e de Irminger, reproduziam deslocamentos laminares, ou fluxo laminares de ar. Para o estudo das ações do vento em edificações, o túnel de fluxo laminar, foi o único equipamento utilizado, embora desde longa data se soubesse que os resultados assim obtidos afastam-se substancialmente dos valores que poderiam ocorrer, caso a edificação fosse envolvida por um fluxo tubulento.

Portanto, até a terceira década do nosso século, a determinação das forças que o vento introduz nas edificações era baseada em ações estáticas determinadas a partir de:

1- Máximas velocidades observadas para o vento, levando em conta a variação com a altura acima do terreno.

2- Coeficientes aerodinâmicos obtidos em ensaios realizados com modelos nos túneis aerodinâmicos.

Nesta década, a de 30 , surgiram as preocupações com 0 comportamento dinâmico das estruturas e com o comportamento, ou o tratamento, estatístico da velocidade do vento. Complementando estas preocupações, foram realizadas diversas medições em edifícios de grande altura, como os de Rathbun em 1940, no "Empire State Building". 
A queda da ponte "Tacoma Narrows" acelerou a busca de um modelo mais real, que methor reproduzisse as solicitaçōes devidas ao vento que as estruturas estão sujeitas, pois a ponte atingiu o colapso sob vento com velocidade inferior à máxima prevista para aquele local. Não deve ser também esquecido, que a densidade relativa das construções diminuiu muito ao longo do tempo, devido ao emprego de materiais mais leves, mais resistentes e à contribuição dos sistemas estruturais que tornaram-se mais monolíticos.

A soma destes fatores fez crescer a influência da ação do vento em relação às demais ações, tornando necessária a utilização de um processo mais preciso para a determinação destes efeitos, pois a utilização dos procedimentos já descritos, conduzia a construções com dois terços do material estrutural empregado, destinando-se exclusivamente a resistir a estas ações.

O aperfeiçoamento deste modelo foi realizado baseando-se principalmente nos estudos de Davenport, que sugeriu o desenvolvimento de túneis que simulassem um comportamento mais próximo do real, gerando fluxos de ar com variações ao longo da altura e que simulassem 0 fluxo turbulento. Surgiram assim resultados de diversas simulaçōes, que permitiram aperfeiçoar as recomendações até então existentes.

O primeiro conceito a ser aperfeiçoado foi o de utilizar a velocidade média máxima, obtida ao tratar o vento como um fenômeno aleatório e não mais um valor máximo medido no local, em um intervalo pequeno de tempo. Como complementação considerou-se que ocorram flutuaçōes, também aleatórias, em torno desta velocidade, denominadas de rajadas ou de turbulências.

Atualmente, para o projeto estrutural, utiliza-se a velocidade média máxima na determinação das solicitaçōes estáticas e as propriedades das rajadas para os efeitos dinâmicos. A norma ABNT NBR-6123 [ 6 ], na sua edição de junho de 1988 , permite abordar estas duas considerações, que estão contidas nos itens 4.2 e 4.3 respectivamente.

Para a análise estática, deve ser considerada a variação da velocidade média mâxima, que é chamada de velocidade básica $\left(\mathbf{V}_{\mathbf{o}}\right)$, medida a $10 \mathrm{~m}$ de altura em terreno plano e aberto, sendo sua variação levada em conta por meio de dois coeficientes, identificados como $\mathbf{S}_{\mathbf{1}}$ e $\mathbf{S}_{\mathbf{2}}$, que consideram as variações do relêvo e das obstruções em volta da construção, respectivamente. 
Um último fator $\mathbf{S}_{\mathbf{3}}$ deve ser aplicado visando considerar a importância social da edificação.

Para esta velocidade final, obtida pela multiplicação de $V_{0}$ pelos três fatores de correção, a norma reserva a denominação de velocidade característica, $\left(\mathbf{V}_{\mathbf{k}}\right)$. Portanto:

$$
V_{k}=V_{0} s_{1} s_{2} s_{3}
$$

Sendo os valores de $\mathbf{V}_{\mathbf{o}}$ e de seus coeficientes obtidos facilmente do corpo da norma, em função das particularidades de cada construção.

Vale lembrar que as curvas com os valores de $\mathbf{V}_{\mathbf{0}}$ (denominadas de isopletas), representam as velocidades de rajadas com duração de 3 segundos, que podem ser excedidas, em média, uma vez em 50 anos, a 10 metros acima do solo, em campo aberto e plano.

À velocidade caracteristica corresponde uma pressão de obstrução, determinada pela aplicação das equaçōes de Bernoullit a escoamento de fluidos, que pode conduzir a:

$$
q=0,613 V_{k}^{2}\left(e m ~ N / m^{2} \text {, entrando-se com } V_{k} e m ~ m / s\right)
$$

Evidentemente o valor calculado para a pressāo q só se fará sentir nos pontos onde ocorre a estagnação do fluído, ocorrendo flutuações nos demais pontos, em função da variação da velocidade de escoamento nestes pontos.

Como pode-se perceber, estas variações levam em conta as formas e as dimensões das edificaçōes, as caracteristicas como rugosidade das suas superfícies, a presença de quinas, de reentrâncias, de aberturas, e demais particularidades.

Surgem assim os coeficientes aerodinâmicos, que procuram retratar os efeitos que uma determinada construção sofrerá quando submetida a um fluxo de ar, com uma velocidade de escoamento da ordem de $V_{k}$.

Para o projeto estrutural de edificios de andares múltiplos, possui grande importância o coeficiente de arrasto, que permite determinar a força global que o vento aplica na construção, na direção do fluxo, denominada de força de arrasto, pela expressão:

$$
F_{a}=C_{a} q A_{e}
$$


onde: $C_{a}=$ Coeficiente de arrasto, obtido nos gráficos das figuras 4 ou 5 da norma, em função das relaçōes entre as dimensões da edificação e do regime de escoamento, se laminar ou turbulento, respectivamente.

$A_{e}=$ Área frontal efetiva, ou seja a projeção ortogonal da superfície da edificação em um plano perpendicular à direção do vento.

Nas construções isoladas, que possuem dupla simetria, tanto elástica como geométrica, é possivel supor que a força de arrasto, ou mesmo suas componentes, passem pelo centro elástico da estrutura, provocando apenas deslocamentos de translação.

Nas construções que não atendam estas condições, pode ocorrer uma excentricidade em relação ao centro elástico, que introduzirá também um momento de torção na estrutura com, consequentemente, deslocamentos rotacionais.

A Norma NBR-6123, no item 6.6.2, apresenta valores que devem ser adotados para as excentricidades, em construções paralelepipédicas, com ou sem efeitos de vizinhança, mesmo para aquelas onde é possivel supor que a resultante passe pelo centro elástico. Nos demais casos os valores destas excentricidades devem ser determinados por meio de ensaios em túneis de vento.

A norma ainda apresenta, no anexo $\mathrm{G}$, algumas orientaçōes de como considerar os efeitos que outras construções, existentes ou a construir, podem provocar na construção em estudo. A máxima majoração prevista é de $30 \%$, mas cabe sempre ao projetista, em função das condiçōes locais, decidir pela aplicação ou não deste incremento.

Para o estudo dos efeitos dinâmicos que o vento pode introduzir em uma estrutura, o item 4.3 da norma NB-6123, remete para o capítulo 9 e exemplos, no anexo $\mathrm{I}$.

Neste capítulo encontra-se a indicação de que construções com periodo fundamental de oscilação, igual ou inferior a 1 segundo, não precisam ser analisadas, uma vez que os efeitos dinâmicos podem ser considerados como incluídos na análise estática, dentro do fator $\mathbf{S}_{\mathbf{2}}$. Nas construções com período maior que 1 segundo deve-se proceder a esta análise, sendo definida a velocidade de projeto, como:

$$
\bar{V}_{p}=0,69 V_{0} s_{1} S_{3}
$$


O que está embutido nesta expressão é uma correção da velocidade básica, retirada de curvas de 3 segundos de duração, para uma situação onde este tempo seja de 10 minutos (600 segundos), ainda a 10 metros acima do solo em terreno aberto e plano (categoria II).

Portanto, para os efeitos dinâmicos a norma admite que a velocidade média ou de projeto, permaneça constante durante um tempo não inferior a 10 minutos, embora durante este tempo ocorram flutuações em torno deste valor, denominadas de rajadas.

A outra hipótese assumida é que a velocidade média produz na edificação efeitos puramente estáticos, designados de resposta média, enquanto as rajadas podem induzir oscilações na direção da resposta média, denominadas de resposta flutuante.

Estas respostas podem ser obtidas na forma de deslocamentos, de forças, de velocidades ou de acelerações do movimento, em função das características elásticas, geométricas e dinâmicas da estrutura, dentro da teoria da vibração, que apresenta soluções quase exatas para este problema.

Em estruturas com vários graus de liberdade, como é o caso dos edifícios de andares múltiplos, onde cada nó apresenta seis graus de liberdade, as soluções podem conduzir a sistemas com elevado número de equaçōes. Porém, aplicando algumas simplificações, com pequeno prejuizo na precisão, podem ser obtidas estas respostas, que não devem divergir mais do que $10 \%$ dos valores a serem obtidos sem estas simplificaçōes.

Para tanto, assumindo-se que a ação possa ser desdobrada em uma força constante no tempo ( $\left.\boldsymbol{F}_{\text {con }}\right)$ e uma outra cujo valor varia com o tempo $\left(\boldsymbol{F}_{\text {var }}\right)$, a resposta de uma estrutura com um grau de liberdade, pode ser escrita, em função das forças envolvidas, como:

$$
F_{i}+F_{c}+F_{e}=F_{c o n}+F_{v a r}
$$

sendo: $F_{i}=$ Força de inércia, depende da massa da construção.

$F_{c}=$ Força de amortecimento, depende do material empregado

$\mathrm{F}_{\mathrm{e}}=$ Força elástica, depende da rigidez elástica da estrutura.

Como se sabe, $\mathbf{F}_{\mathbf{e}}$ é proporcional ao deslocamento $(\mathbf{x})$, portanto:

$$
F_{e}=k \cdot x=k \cdot x_{e}+k \cdot x_{d}
$$




$$
\text { sendo } \begin{aligned}
x & =x_{e}+x_{d} \\
x & =\text { deslocamento total } \\
x_{e} & =\text { deslocamento estático } \\
x_{d} & =\text { deslocamento dinâmico }
\end{aligned}
$$

Quanto ao amortecimento, no caso apenas o estrutural, sabe-se que está presente em todos os sistemas oscilatórios, tendo o efeito de absorver energia, que é dissipada sob a forma de calor.

Este amortecimento pode ser representado pelo atrito molecular interno do material estrutural, como também pelo atrito ao deslizamento. Por ser difícil a formulação matemática do amortecimento, admite-se alguns modelos que quase sempre conduzem a respostas satisfatórias.

Dentre esses modelos, o que conduz ao tratamento matemático mais simples, é o que considera a força de amortecimento viscoso, que pode ser escrita como:

$$
F_{c}=c \cdot x^{\prime}
$$

onde: $\quad c=$ constante de proporcionalidade.

$X^{\prime}=$ velocidade do deslocamento, que varia no tempo.

Finalmente a força de inércia, que depende da massa do sistema, cujo valor pode ser obtido pelo produto da massa pela aceleração do movimento, que também varia no tempo, podendo ser escrita como:

$$
F_{i}=m \cdot x^{\prime \prime}
$$

onde: $\mathrm{m}$ = massa do sistema

$x^{\prime \prime}=$ aceleração do deslocamento, que também varia com o tempo

Substituindo as forças de resposta da estrutura, na equação das forças presentes no sistema ( 3.3 .5 ), chega-se a:

$$
m x^{\prime \prime}+c x^{\prime}+k x_{e}+k x_{d}=F_{c o n}+F_{v a r}
$$

Como $\mathbf{k} \mathbf{x}_{\mathbf{e}}=\mathbf{F}_{\text {con }}$, obtém-se a equação final de um movimento expressa da seguinte forma: 


$$
m x^{\prime \prime}+c x^{\prime}+k x_{d}=F_{v a r}
$$

chamando-se a atenção de que todos os têrmos são variáveis no tempo.

Para um sistema com vários graus de liberdade, a equação anterior, escrita sob forma matricial será:

$$
[M]\left\{\ddot{U}_{t}\right\}+[C]\left\{\dot{U}_{t}\right\}+[K]\left\{U_{t}\right\}=\left\{F_{t}\right\}
$$

O sistema, com a apresentação matricial, pode ser resolvido, fornecendo os valores dos deslocamentos, frequências e formas nodais, embora como já afirmado, com um número bastante grande de equaçōes.

Para o projetista interessa visualizar o comportamento da estrutura que está concebendo e esta visualização será mais rápida e mais objetiva se o comportamento puder ser analisado por meio de um procedimento manual, cuja solução fique restrita a umas poucas variáveis.

Portanto, ao menos na fase de ante-projeto, é recomendável uma análise simplificada da ação dinâmica do vento que, embora bastante simples, leve em conta todos os conceitos da teoria da vibração.

Antes de apresentar este procedimento simplificado, até para uma melhor compreensão da sua amplitude e campo de aplicação, é importante uma breve recordação da teoria da vibração, deduzida a partir do princípio de conservação de energia, que será a base do processo resolutivo.

Deste modo, considerando a estrutura submetida a ação do vento, como um sistema conservativo, pode-se escrever:

$$
E_{t}=E_{p}+E_{c}=\text { Constante }
$$

Sendo $E_{c}$ a parcela da energia cinética, que pode ser escrita como:

$$
E_{c}=m v^{2} / 2
$$

A energia potencial é equivalente ao trabalho que a força elástica (kx) desenvolve ao longo do deslocamento $\mathbf{x}$, ou seja:

$$
E_{p}=\frac{1}{2} \int k x d x=k x^{2} / 2
$$


Como o sistema é conservativo, a soma destas parcelas será sempre constante, logo:

$$
m v^{2}=k x^{2}=\text { Constante }
$$

A velocidade deste sistema pode ser entendida como a primeira derivada do deslocamento. Substituindo $\mathbf{v}$ por $\mathbf{x}^{\prime}$ na expressão ( 3.3.14), após elevá-lo ao quadrado, derivando os dois têrmos em relação ao tempo e eliminando o têrmo comum $\mathbf{x}$ ', obtém-se:

$$
m x^{\prime \prime}+k x=0
$$

Sendo esta a expressão do movimento harmônico não amortecido, deduzida normalmente com a utilização da segunda lei de Newton.

Tratando-se de um movimento harmônico, suposto sem força excitadora externa, a solução desta equação pode ser representada por uma curva senoidal, como por exemplo:

$$
x=A \operatorname{sen}(\omega t)
$$

cujas derivadas sucessivas são:

$$
\begin{aligned}
& x^{\prime}=A \omega \cos (\omega t) \\
& x^{\prime \prime}=-A \omega^{2} \operatorname{sen}(\omega t)
\end{aligned}
$$

Substituindo na equação de movimento ( 3.3 .15 ) encontra-se:

$$
-m A \omega^{2} \operatorname{sen}(\omega t)+k A \operatorname{sen}(\omega t)=0
$$

Colocando a equação anterior em têrmos de $\boldsymbol{\omega}$, consegue-se explicitar:

$$
\omega=\sqrt{\mathrm{k} / \mathrm{m}} \quad(\mathrm{rad} / \mathrm{s})
$$

Sendo a a velocidade angular ou frequência angular natural do sistema. 
A frequência natural do sistema, em ciclos por segundo, será:

$$
f=\omega / 2 \pi \quad(\text { Hertz }=\text { cps })
$$

E o período, que é o inverso da frequência:

$$
T=1 / f=2 \pi / \omega \quad \text { (segundos) }
$$

Introduzindo o amortecimento na equação do movimento, ela se torna, como já mostrado, na equação ( 3.3 .9 ) porém, tomando apenas a sua parte homogênea, encontra-se:

$$
m x^{\prime \prime}+c x^{\prime}+k x=0
$$

A solução desta equação, para não apresentar a derivada segunda como constante ou nula, precisa possuir ao menos um têrmo exponencial, sendo usualmente empregada a expressão:

$$
x=e^{\text {st }}
$$

onde s é uma constante, cujo valor será determinado oportunamente. As derivadas sucessivas serão:

$$
\begin{aligned}
& x^{\prime}=s e^{s t} \\
& x^{\prime \prime}=s^{2} e^{s t}
\end{aligned}
$$

que substituídas na equação diferencial ( 3.3.22.a ) fornecem, após cancelar o têrmo comum $\mathrm{e}^{\text {st: }}$

$$
m s^{2}+c s+k=0
$$

que será satisfeita para os seguintes valores de $\mathrm{s}$ :

$$
s_{1,2}=-\frac{c}{2 m} \pm \sqrt{\frac{c^{2}-4 m k}{4 m^{2}}}=-\frac{c}{2 m} \pm \sqrt{\left(\frac{c}{2 m}\right)^{2}-\frac{k}{m}}
$$


Como pode ser observado na equação anterior, o valor de $s$ pode ser, ao mesmo tempo, positivo e negativo. Deste modo, a solução precisará ser assumida como:

$$
x=A e^{s_{1} t}+B e^{s_{2} t}
$$

Substituindo as expressões de $\mathbf{s}$ da equação ( 3.3 .24 ) na equação anterior ( 3.3 .25 ) encontra-se a solução clássica para a solução da equação do movimento oscilatório não excitado, que é apresentada como:

$$
x=e^{-\frac{c t}{2 m}}\left\{A e^{\sqrt{\left.\left(\frac{c}{2 m}\right)^{2}-\frac{k}{m}\right\}} t}+B e^{-\sqrt{\left\{\left(\frac{c}{2 m}\right)^{2}-\frac{k}{m}\right\}} t}\right\}
$$

Observando que o primeiro têrmo exponencial decresce com o tempo. Dos demais têrmos interessa à análise o resultado sob o radical, que pode conduzir a três situações distintas.

a) Se $(c / 2 m)^{2}>k / m$ - A solução é real e não ocorre oscilação.

O movimento é considerado superamortecido.

b) $\mathrm{Se}(\mathrm{c} / 2 \mathrm{~m})^{2}<\mathrm{k} / \mathrm{m}$ - A solução é imaginária, ocorrendo oscilações.

O movimento é dito subamortecido.

c) $\mathrm{Se}(\mathrm{c} / 2 \mathrm{~m})^{2}=\mathrm{k} / \mathrm{m}$ - O expoente é nulo, sendo o valor do amortecimento denominado de crítico, que divide a situação oscilatória da não oscilatória $\left(c_{c}^{2}=c^{2}=4 k m\right.$ )

Para esta última situação, o valor do amortecimento crítico $\left(\mathbf{c}_{\mathrm{c}}\right)$ será:

$$
c=c_{c}=2 \sqrt{k m}=2 m \omega=2 k / \omega
$$

Podendo-se agora definir como fator de amortecimento a relação:

$$
\xi=c / c_{c}
$$


$\mathrm{Na}$ figura seguinte é possivel verificar a influência do amortecimento, em um sistema com movimento harmônico. Esta influência é significativa no período e na frequência do sistema sub-amortecido, uma vez que os demais, por não oscilarem, não apresentam valores definidos.

Assim, colocando em gráfico as três condições, obtém-se:

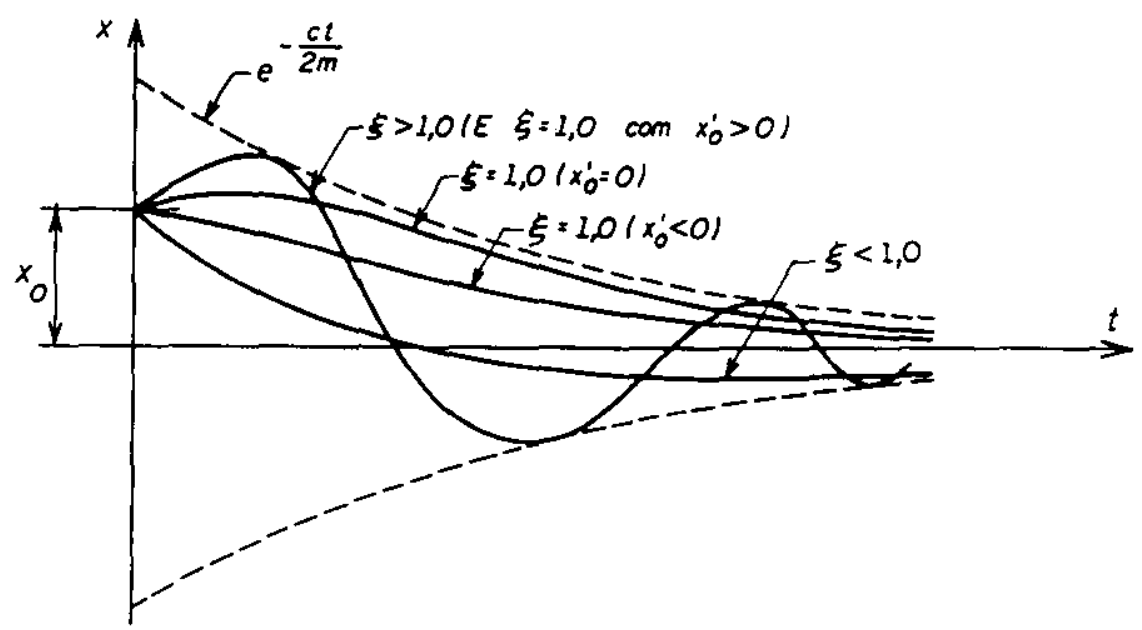

Figura 3.2 - Influência do Amortecimento

Portanto, para o sistema sub-amortecido, encontra-se como solução da equaçāo diferencial, um valor menor do que zero sob o radical, que conduz a uma solução complexa, ou seja:

$$
s=-\frac{c}{2 m} \pm i \sqrt{\frac{k}{m}-\left(\frac{c}{2 m}\right)^{2}}
$$

onde: $i=\sqrt{-1}$ é a unidade imaginária.

Chamando a frequência angular natural de um movimento subamortecido de $\omega$, as equações de Euler permitem escrever:

$$
\begin{aligned}
& e^{i \omega_{a}}=\cos \omega_{a}+i \operatorname{sen} \omega_{a} \\
& e^{-i \omega_{a}}=\cos \omega_{a}-i \operatorname{sen} \omega_{a}
\end{aligned}
$$

Pela equação $(3.3 .19)(\omega=\sqrt{k / m})$ é possivel deduzir a equação para a frequência em um movimento subamortecido, ou seja: 


$$
\omega_{a}=\sqrt{k / m-(c / 2 m)^{2}}
$$

Portanto, a equação ( 3.3.26) poḍe ser escrita como:

$$
x=e^{-\frac{c t}{2 m}}\left(C \cos \omega_{a} t+D \operatorname{sen} \omega_{a} t\right)
$$

que pode ser resolvida de modo mais simples e objetivo.

Finalmente, escrevendo a frequência de um movimento amortecido em função da frequência do mesmo movimento sem amortecimento $(\omega=\sqrt{\mathrm{k} / \mathrm{m}})$, encontra-se:

$$
\omega_{\mathrm{a}}=\omega \sqrt{1-\xi^{2}}
$$

quando então a frequência natural será escrita como:

$$
f_{a}=\omega_{a} / 2 \pi=\omega \sqrt{1-\xi^{2}} / 2 \pi
$$

e o período:

$$
\mathrm{T}_{\mathrm{a}}=2 \pi / \omega \sqrt{1-\xi^{2}}
$$

Analisando agora o movimento para a solução particular, que ocorre quando existe uma força externa aplicada, considerando que a mesma varie senoidalmente com o tempo, ou seja:

$$
m x^{\prime \prime}+c x^{\prime}+k x=F \operatorname{sen} \omega t
$$

A solução particular pode ser escrita como:

$$
x=A \operatorname{sen}(\omega t-\phi)
$$

onde: $x=$ amplitude de oscilação

$\omega=$ frequência da solicitação

$\phi=$ ângulo de fase do deslocamento em relação à força de excitação. 
Esta defasagem surge em função das características do sistema, influenciando todo o mecanismo de resposta. Lembrando que em um movimento harmónico a velocidade e a aceleração estão defasadas entre sí e em relação ao deslocamento, fica maís fácil entender este fenômeno. Ou seja, se o movimento pode ser representado pela expressão:

$$
x=A \operatorname{sen} \omega t
$$

suas derivadas, velocidade e aceleração, podem ser escritas como:

$$
\begin{aligned}
& v=x^{\prime}=A \omega \cos \omega t=A \omega \operatorname{sen}(\omega t+\pi / 2) \\
& a=x^{\prime \prime}=-A \omega^{2} \operatorname{sen} \omega t=A \omega^{2} \operatorname{sen}(\omega t+\pi)
\end{aligned}
$$

Substituindo a solução particular e suas derivadas na equação do movimento ( 3.3.34) encontra-se:

$$
F \operatorname{sen} \omega t=k x \operatorname{sen}(\omega t-\phi)+c x \omega \cos (\omega t-\phi)-m x \omega^{2} \operatorname{sen}(\omega t-\phi)
$$

Colocando estes têrmos em um gráfico, como o da figura seguinte, visualiza-se facilmente suas relaçōes, lembrando da defasagem entre deslocamento, velocidade e aceleração:

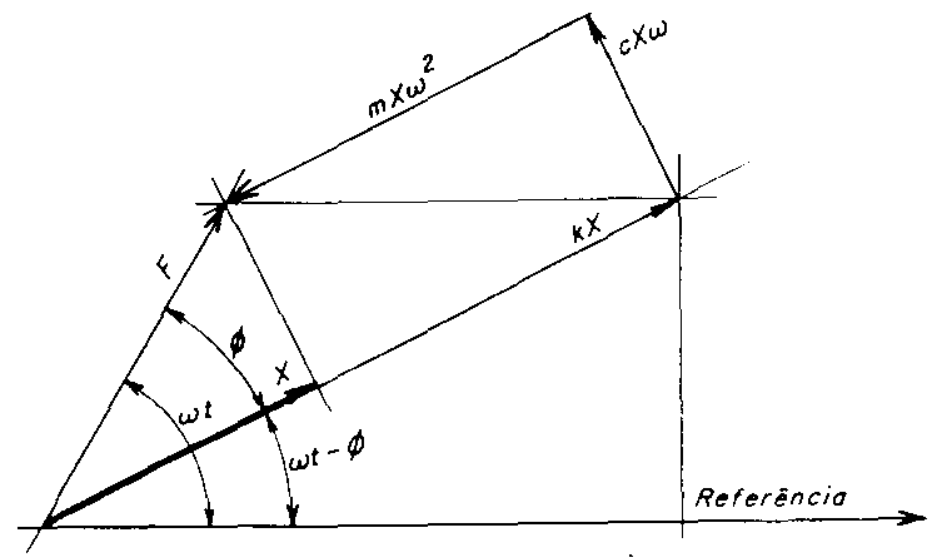

Figura 3.3 - Fases entre DeslocamentoNelocidade/Aceleração

Aplicando Pitágoras ao gráfico é possível retirar as igualdades:

$$
X=\frac{F}{\sqrt{\left(k-m \omega^{2}\right)^{2}+(c \omega)^{2}}}
$$


e, $\quad \operatorname{tg} \phi=\frac{c \omega}{k-m \omega^{2}}$

É possivel escrever estas equações de forma admensional, que permitem uma representação gráfica mais precisa. Para tanto, dividindo o numerador e o denominador das duas equaçōes por $\mathbf{k}$, obtém-se.

$$
\begin{aligned}
& \frac{X k}{F}=\frac{1}{\sqrt{\left[1-\left(\frac{\omega}{\omega_{n}}\right)^{2}\right]^{2}+\left[2 \xi\left(\frac{\omega}{\omega_{n}}\right)\right]^{2}}} \\
& \operatorname{tg} \phi=\frac{2 \xi\left(\frac{\omega}{\omega_{n}}\right)}{1-\left(\frac{\omega}{\omega_{n}}\right)^{2}}
\end{aligned}
$$

Nas equações anteriores foram introduzidas as igualdades:

$$
\begin{aligned}
& \begin{array}{l}
\omega_{n}=\sqrt{k / m}=\text { frequência natural de oscilação para um } \\
\text { movimento não amortecido. }
\end{array} \\
& c_{c}=2 m \omega_{n}=\text { amortecimento crítico } \\
& \xi=c / c_{c}=\text { fraçäo ou fator de amortecimento } \\
& c \omega / k=c_{c} \cdot c . \omega / c_{c} k=2 m \omega_{n} \xi \omega / k=2 \xi \omega / \omega_{n}
\end{aligned}
$$

Como pode ser observado nas equaçōes anteriores, o ângulo de fase ( $\phi$ ) e a deformação relativa ( $\mathbf{X} \mathbf{k} / \mathbf{F}$ onde $\mathbf{F} / \mathbf{k}$ é a deformação elástica e $\mathbf{X}$ é a deformação total ) podem ser expressas apenas em têrmos da razão das frequências e da fração de amortecimento.

Para o ângulo de fase, três casos podem ocorrer:

1- Quando $\omega / \omega_{n}=1$. O ângulo é de $90^{\circ} \mathrm{e} x=F / 2 \xi \mathrm{k}$, que é o valor de ressonância. A força de inércia é aproximadamente igual a força da mola, e a força aplicada é equilibrada pela de amortecimento.

2- Quando $\omega / \omega_{n}<1$. O ângulo é menor que $90^{\circ}$. A força de inércia e a de amortecimento são pequenas e quase iguais entre si. A força aplicada é equilibrada pela força da mola. 
3- Quando $\omega / \omega_{n}>1$. O ângulo é maior que $90^{\circ}$. A força de amortecimento é pequena, bem como a da mola. A força aplicada é quase que totalmente equilibrada pela força de inércia.

A equação da deformação relativa permite uma melhor visualização quando colocada em gráfico, como o da figura abaixo.

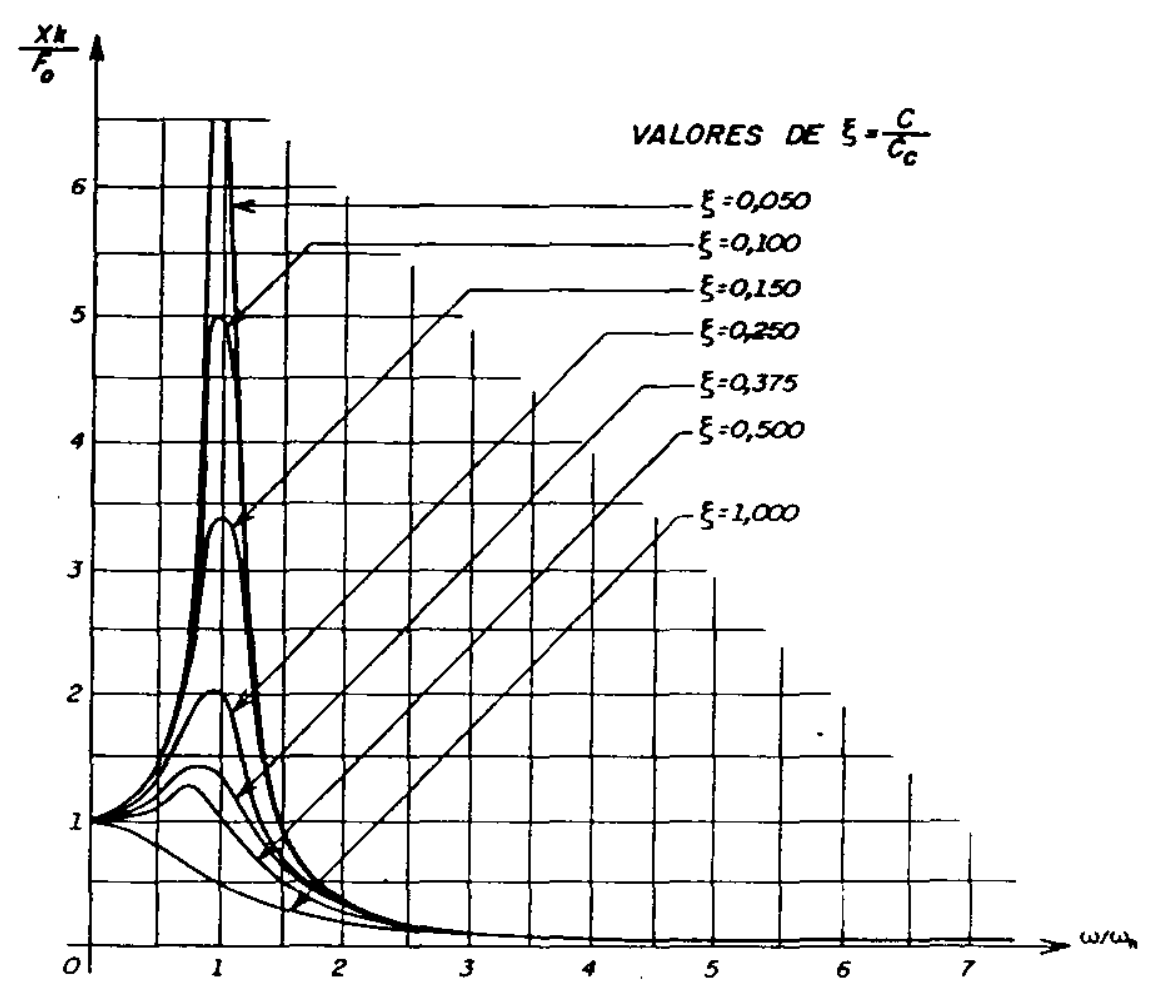

Figura 3.4 - Situações Amortecidas e em Ressonância.

Na figura anterior é possivel observar:

a - A função principal do amortecimento é limitar as deformações quando o comportamento estrutural se aproxima da ressonância.

b - As deformaçōes máximas só ocorrem no ponto de ressonância, para valoreś baixos do fator de amortecimento. Quando $\xi$ é maior que 0,25 as maiores deformações são obtidas no intervalo de $\omega / \omega_{n}$ localizado entre 1,0 e 0,6 .

A equação do movimento, introduzindo $\xi$ e $\omega_{n}$ torna-se: 


$$
x^{\prime \prime}+2 \xi \omega_{n} x^{\prime}+\omega_{n}^{2} x=F(\operatorname{sen} \omega t) / m
$$

cuja solução completa é:

$$
x=\frac{F}{k} \frac{\operatorname{sen}(\omega t-\phi)}{\sqrt{\left[1-\left(\frac{\omega}{\omega_{n}}\right)^{2}\right]^{2}+\left[2 \xi\left(\frac{\omega}{\omega_{n}}\right)\right]^{2}}}+A e^{-\xi \omega_{n} t} \operatorname{sen}\left(\sqrt{1-\xi^{2}} \cdot \omega_{n} t+\phi_{1}\right)
$$

onde: $\phi=$ Fase da solução particular

$\phi_{1}=$ Fase da solução homogênea

$A=$ Coeficiente, a ser determinado

Entretanto, a equação anterior é uma resposta determinística, para um problema também determinístico, uma vez que foi suposto conhecer-se o valor da força $\mathbf{F}$ e a sua exata variação no tempo.

A incidência do vento não possui uma característica determinística, devendo ser considerada como aleatória. Esta classificação decorre do fato de que esta ação não pode ser pré-determinada, nem em direção, intensidade ou distribuição de densidade no tempo.

Porém, baseados em um grande número de medições já realizadas, foi possivel observar uma certa regularidade nestas ações, o que as tornam passiveis de um tratamento estatístico.

Analisando-se diversos registros de velocidades do vento, observase que as médias para um mesmo intervalo de tempo não diferem significativamente entre si. Pode também ser observado uma igualdade entre as médias de cada registro, e o resultado de cada registro que é o mesmo para qualquer outro registro escolhido e igual à média do conjunto.

Portanto, o vento pode ser tratado estatísticamente, como um acontecimento aleatório, porém estacionário e ergódico. Deste modo a ação do vento pode ser representada pela média das suas intensidades para um intervalo de tempo razoavelmente longo [ 12 ].

Para a equação de movimento, analisada anteriormente, viu-se que a solução geral, ou resposta, consiste do têrmo transiente, ou solução homogênea, que depende das condições iniciais e que diminui com o tempo, devido ao amortecimento e do têrmo que reflete a solução particular e que este só depende da força de excitação. 
Entretanto, em um acontecimento ergódico, define-se função da resposta da frequência, como a relação entre a entrada e a saída sob as condiçōes do estado permanente, com a entrada representada por uma funçăo harmônica no tempo, com amplitude unitária. Exclue-se nesta definição o têrmo transiente, uma vez que as condições iniciais e o ângulo de fase tem seus efeitos amortecidos, ou diluídos ao longo do evento.

Portanto, retomando a equação do movimento:

$$
m x^{\prime \prime}+c x^{\prime}+k x=F_{(t)}
$$

Admitindo $F_{(t)}=e^{i \omega t}$, como a entrada, obtém-se como saída no estado permanente ( tempo tendendo a infinito ):

$$
x=f_{(\omega)} e^{i \omega t}
$$

que, substituída na equação do movimento, resulta na função da resposta da frequência $\mathbf{f}_{(\omega)}$, que é:

$$
\begin{aligned}
& f_{(\omega)}=\frac{1}{k-m \omega^{2}+i \omega c} \\
& f_{(\omega)}=\frac{1}{k} \frac{1}{1-\left(\frac{\omega}{\omega_{n}}\right)^{2}+i 2 \varepsilon\left(\frac{\omega}{\omega_{n}}\right)}
\end{aligned}
$$

Sendo $f_{(\omega)}$ uma função completa de $\omega / \omega_{n}$ e $\xi$, tendo como dimensão um comprimento (deslocamento) sobre força.

Como foram ignoradas a fase e as condições iniciais, busca-se agora a energia média, que pode ser associada à média quadrática das elongaçōes $\underline{\mathbf{x}}$.

O valor médio quadrático $(\mathbf{x})^{2}$, é obtido integrando-se $\mathbf{x}$ em um intervalo de tempo $\mathbf{t}$, tomando-se:

$$
\bar{x}^{2}=\lim _{t \rightarrow \infty} \frac{1}{t} \int_{0}^{t} x^{2} d t
$$

que é chamado de momento de segunda ordem, sendo: 


$$
\bar{x}_{(t)}=\lim _{t \rightarrow \infty} \frac{1}{t} \int_{0}^{t} x_{(t)} d t
$$

o momento de primeira ordem, que representa a média ou o valor médio, de uma quantidade amostrada um grande número de vezes, durante um longo periodo de tempo.

Para uma distribuição de densidades em probabilidade, a variância é definida como o valor médio quadrático em relação à média aritmética, ou seja:

$$
\sigma^{2}=\int_{-\infty}^{+\infty}(x-\bar{x})^{2} p(x) d x
$$

que fornece: $\quad \sigma^{2}=\bar{x}^{2}-(\bar{x})^{2}$

onde: $\bar{x}=$ valor médio, coincide com a ordenada do centro da curva normal $\bar{x}^{2}=$ valor médio quadrático

$\sigma^{2}=$ variância

$\sigma=$ desvio padrão

No caso do vento, a deformação $\mathbf{x}$ será o valor médio das respostas às flutuações da velocidade básica, ou rajadas, que representam também a flutuação média da energia cinética do vento.

Tratando-se de um sistema estrutural com comportamento linear, as deformações serão proporcionais às ações empregadas, podendo-se tomar a entrada pela saida. Assim:

$$
p_{(z)}=p_{e}+p_{d}
$$

onde: $p_{(z)}=$ pressão total em uma altura $(z)$.

$\mathrm{p}_{\mathrm{e}}=$ pressão resultante da velocidade média

$p_{d}=$ pressão resultante da energia das rajadas .

A pressão provocada pelo vento varia com a altura e com as condições do relêvo, que como a Norma NBR-6123 deixa bem claro no item 5.3.1, definem as cinco categorias de rugosidade, com valores dos índices $\mathbf{p}$ e b variando para cada categoria. 
Deste modo, a pressão devida à velocidade média $\left(\bar{v}_{p}\right)$ pode ser representada como:

$$
p_{e}=\bar{q}_{0} b^{2}\left(z / z_{r}\right)^{2 p}
$$

A pressão devida à velocidade de rajada, deve sofrer também a influência dos fatores $\mathbf{p}$ e $\mathbf{b}$, para a categoria respectiva, mas deve refletir também a influência da resposta dinâmica.

Esta influência pode ser assumida como uma variação da resposta estática, devida à aplicação de um coeficiente de amplificação, que depende da fração de amortecimento estrutural e da razão entre as frequências, a de excitação e a natural da estrutura.

Este coeficiente de amplificação pode ser colocado em gráfico, uma vez que sofre a influência de diversas variáveis. Nos gráficos da NBR 6123, este coeficiente é determinado em funçāo da razão entre $\ell_{1}$ e $h$, onde $\ell_{1}$ é a dimensão da edificação transversal ao sentido do vento e $\mathbf{h}$ a altura da edificação. $O$ outro fator de entrada no gráfico é a relação:

$$
\bar{V}_{p} T / L=\bar{V}_{p} / f L
$$

onde $\bar{V}_{p}$ é a velocidade média de projeto, $T$ é o periodo, inverso da frequência, e L é um comprimento de referência, tomado como 1800m.

Para cada categoria de terreno existem, na norma, gráficos específicos.

Uma vez determinado o fator de amplificação, pelo gráfico correspondente da norma, pode-se determinar a pressão de rajada pela expressão:

$$
p_{d}=\bar{q}_{o} b^{2} \xi\left(h / z_{f}\right)^{p}(z / h)^{\gamma} \frac{1+2 \gamma}{1+\gamma+p}
$$

onde: $z_{r}=10 m$ ( altura de referência )

$\gamma=$ modo fundamental de vibração

Portanto, a pressão total pode ser representada por:

$$
p_{(z)}=q_{(z)}=\bar{q}_{0} b^{2}\left[\left(z / z_{r}\right)^{2 p}+\xi\left(h / z_{r}\right)^{p}(z / h)^{\gamma} \frac{1+2 \gamma}{1+\gamma+p}\right]
$$


A força total exercida pelo vento, que engloba os efeitos estático e dinâmico, pode ser obtida pela expressão:

$$
F_{(z)}=q_{(z)} \ell_{1} C a
$$

Sendo $\mathrm{C}_{\mathrm{a}}$ o coeficiente de arrasto respectivo, para vento turbulento ou laminar, determinado segundo as relaçōes da edificação, dos gráficos específicos que constam do corpo da norma e $\ell_{1}$ a largura da edificação, valendo observar que $F_{(z)}$ varia com a altura.

Esta é a formulação do modelo contínuo simplificado, aplicável a construções com altura inferior a 150 metros exclusivamente apoiadas na base, com seção constante ao longo da altura. A norma também apresenta algumas formulaçōes para calcular o período fundamental, em diversos tipos de construções, com os respectivos valores de $\gamma$ e de $\xi$.

No caso de construçōes com variações significativas ao longo da altura, a norma apresenta um modelo discreto, que permite calcular os deslocamentos, tanto o estático como o dinâmico.

Para este caso deve-se tomar:

$$
x_{T}=x_{e}+x_{d}
$$

$$
\text { Sendo: } \quad \begin{aligned}
x_{e} & =\bar{q}_{0} b^{2} C_{a} A_{0}\left(z / z_{r}\right)^{2 p} \\
x_{d} & =F_{H} \psi x \\
\psi & =m / m_{0} \\
F_{H} & =\bar{q}_{0} b^{2} A_{0} \frac{\sum_{i=1}^{n} \beta_{i} x_{i}}{\sum_{i=1}^{n} \psi_{i} x_{i}^{2}} \varepsilon \\
\beta_{i} & =C_{a i} \frac{A_{i}}{A_{0}}\left(z_{i} / z_{r}\right)^{p} \\
i & =\text { número de partes em que foi dividida a estrutura. } \\
& \text { Ideal } n \geq 10 . \\
A_{0} & =\text { área de referência }=\Sigma A_{i} \\
m_{0} & =\text { massa de referência }=\Sigma m_{i}
\end{aligned}
$$


Entretanto, neste caso, fica a critério do calculista a determinação das frequências e do periodo, necessários para a determinação do fator de amplificação $\xi$.

Quando ocorrem variações na eștrutura, tanto elásticas, geométricas ou de densidade, pode ser necessário um número de subdivisões maior do que 10, que devem conduzir a um grande número de graus de liberdade e, consequentemente, de equaçōes a serem resolvidas.

Nestes casos e mesmo em qualquer outro, na determinação da frequência fundamental, ou de primeiro modo, pode ser empregado o método de Raleigh, que permite uma rápida visualização do problema, por meio de um procedimento manual.

Neste método, a frequência natural é determinada, igualando-se a energia cinética, representada pela energia de massa, com a energia potencial, representada pela energia de deformação.

Sendo o sistema conservativo, pode-se afirmar:

1 - Nos pontos de máximo deslocamento a velocidade é nula, portanto a energia cinética também o é, sendo que a energia total do sistema é convertida em energia potencial, que neste ponto atinge o seu valor máximo.

2- Nos pontos onde o deslocamento é nulo, quando o sistema passa pela origem, a energia potencial é nula e a velocidade atinge seu valor máximo, convertendo toda a energia do sistema em energia cinética, que também atinge, neste ponto, seu valor máximo.

3- Como o sistema é conservativo pode-se escrever a equaçāo que permite determinar a frequência natural de um sistema oscilatório, igualando-se as várias energias envolvidas no sistema, ou seja:

$$
E_{t}=E_{p}=E_{c}
$$

Este foi o procedimento utilizado para determinar a equação de $\omega$, na formulação anterior, aplicado a um sistema com um grau de liberdade.

A contribuição de Raleigh foi mostrar que este procedimento pode ser empregado, com a mesma simplicidade, em sistemas com diversos graus de liberdade. 
Sob formulação matricial pode-se escrever o método da seguinte forma:

$$
\begin{aligned}
& E_{c}=\frac{1}{2} \omega^{2} X^{\prime} M X \\
& E_{p}=\frac{1}{2} X^{\prime} K X
\end{aligned}
$$

sendo: $M=$ matriz de massa

$\mathrm{K}=$ matriz de rigidez

$X=$ vetor dos deslocamentos

igualando as duas expressões ( $3.3 .56 \mathrm{a}$ ) e ( $3.3 .56 \mathrm{~b}$ ), tira-se:

$$
\omega^{2}=\frac{X^{\prime} K X}{X^{\prime} M X}
$$

sendo esta expressão denominada de quociente de Railegh.

$O$ vetor dos deslocamentos pode ser montado, mediante a adoção de uma curva de deformação para a estrutura que determine uma dependência entre os deslocamentos:

$$
x=x_{1}+c_{2} x_{2}+c_{3} x_{3}+\ldots
$$

Assim:

$$
X^{\prime} K X=X_{1}^{\prime} K X_{1}+C_{2}^{2} X_{2}^{\prime} K X_{2}+C_{3}^{2} X_{3}^{\prime} K X_{3}+\ldots
$$

e,

$$
X^{\prime} M X=X_{1}^{\prime} M X_{1}+C_{2}^{2} X_{2}^{\prime} M X_{2}+C_{3}^{2} X_{3}^{\prime} M X_{3}+\ldots
$$

Eliminando os termos cruzados $\mathbf{X}_{\mathbf{i}} \mathbf{K X}_{\mathbf{i}}$ e $\mathbf{X}_{\mathbf{i}} \mathbf{M} \mathbf{X}_{\mathbf{i}}$ pelas condições de ortogonalidade e observando que:

$$
X_{i}^{\prime} K X_{i}=\omega_{i}^{2} X_{i}^{\prime} M X_{i}
$$

o quociente de Raleigh torna-se:

$$
\omega^{2}=\omega_{1}^{2}\left[1+C_{2}^{2}\left(\frac{\omega_{2}^{2}}{\omega_{1}^{2}}-1\right) \frac{X_{2}^{\prime} M X_{2}}{X_{1}^{\prime} K X_{1}}+\ldots\right]
$$


Normalizando $X_{j}^{\prime} M X_{i}$ obtém-se para o quociente:

$$
\omega^{2}=\omega_{1}^{2}\left[1+C_{2}^{2}\left(\frac{\omega_{2}^{2}}{\omega_{1}^{2}}-1\right)+\ldots\right]
$$

Como $\omega_{1}<\omega_{2}<\omega_{3}$ torna-se evidente que $\omega>\omega_{1}$, uma vez que $\omega_{2} / \omega_{1}>1$.

Portanto, $\omega$ aproxima-se do valor exato pelo lado alto, sendo tão ou mais exato, quanto mais próximo do valor real dos deslocamentos for a curva de deformação admitida inicialmente. $O$ êrro cometido na avaliação de a é proporcional ao quadrado dos coeficientes $\mathbf{C}_{\mathbf{i}}$, que representam o desvio da curva exata para a curva tomada como referência.

Caso se tome como referência a curva exata, os coeficientes $C_{i}$ serão iguais a zero, a frequência determinada será a exata e para qualquer outra curva de referência a frequência calculada será mais alta que a exata.

Nos casos usuais, a adoção da curva de deflexão estática conduz a um valor razoavelmente aproximado da frequência real. Para obter uma exatidão maior, a curva de referência pode ser repetidamente recalculada. Esta é a forma usualmente empregada nos programas computacionais para a determinação das frequências naturais de uma estrutura.

Para aplicações manuais, pode-se considerar a estrutura como uma barra, com inércia e massa constante ao longo do comprimento. Neste caso pode-se fazer:

$$
E_{c}=\frac{1}{2} \int m\left(x^{\prime}\right)^{2} d z=\frac{m \omega^{2}}{2} \int x^{2} d z+C_{1}
$$

onde $\mathbf{m}$ é a massa por unidade de comprimento e $\mathbf{x}$ as deformações de referência.

A energia potencial é determinada pelo trabaiho a que a estrutura foi submetida e se acumulou como energia elástica. Sendo $M$ o momento de flexão e $\theta$ a inclinação da curva elástica, o trabalho pode ser representado como:

$$
E_{p}=\frac{1}{2} \int M d \theta
$$


Na flexão de vigas: $\quad \theta=x^{\prime}$

e:

$$
1 / R=d \theta / d z=x^{\prime \prime}=M / E I
$$

Substituindo em ( 3.3 .60$)$ encontra-se:

$$
E_{p}=\frac{E I}{2} \int\left(x^{\prime \prime}\right)^{2} d z
$$

Igualando as duas energias, equacionadas em ( 3.3 .59 ) e ( 3.3 .61 ), retira-se:

$$
\omega^{2} \leq \frac{E l \int\left(x^{\prime \prime}\right)^{2} d z}{m \int x^{2} d z}
$$

Para verificar a exatidão do processo, pode-se buscar a frequência de uma viga em balanço, com seção e inércia constantes, submetida apenas ao seu peso, considerado como uniformemente distribuído.

Admitindo-se: $x=x_{0}(1-\cos \pi z / 2 \ell)$, que não é a exata, encontra-se:

$$
\omega=3,6639 \sqrt{E \operatorname{Elg} / p \ell^{4}}
$$

que acusa um êrro de $4,32 \%$ do valor correto que é: $\omega=3,5123 \sqrt{E I / p \ell^{4}}$.

Aplicando agora a expressão exata da elástica de flexão:

$$
x=\frac{p}{24 E I}\left(z^{4}-4 \ell z^{3}+6 \ell^{2} z^{2}\right)
$$

Encontra-se: $\omega=3,5301 \sqrt{\mathrm{Elg} / \mathrm{p} \ell^{4}}$

que acusa êrro de apenas $0,51 \%$ do correto.

Para algumas situações pode ser mais indicado a obtenção da frequência em função de forças concentradas, tanto elásticas como inerciais. Também neste caso o método apresenta bons resultados. 
Como aplicação, pode-se considerar a mesma viga em balanço, porém admitindo-se toda a sua massa concentrada na extremidade livre.

Nesta situação:

$$
\begin{aligned}
& P=p \ell \\
& x=\frac{P}{E l}\left(\frac{\ell z^{2}}{2}-\frac{z^{3}}{6}\right)
\end{aligned}
$$

Encontrando-se:

$$
\begin{aligned}
& \omega=3,5675 \sqrt{E \operatorname{Elg} / \mathrm{P} \ell^{3}} \\
& \omega=3,5675 \sqrt{\mathrm{Elg} / \rho \ell^{4}}
\end{aligned}
$$

ou substituindo $P=p \ell$ chega-se $a$ :

que conduziu a um êrro de apenas $1,57 \%$ do valor correto.

Nos edifícios de andares múltiplos, as ações provocadas pelo vento podem ser aplicadas como concentradas no nivel dos pisos, gerando assim um modelo próximo ao de uma viga em balanço submetida a diversas forças concentradas. Esta situação também pode ser analisada pelo método de Raleigh, que permite uma simplificação ainda maior na sua aplicação.

Seja, por exemplo, uma viga em balanço, submetida a três forças verticais e concentradas, de intensidades $P$, equidistantes entre sí. Para a determinação da frequência natural, vale lembrar a igualdade energética que permite o seu equacionamento.

Porém, a energia potencial pode ser igualada ao somatório do trabalho que as forças realizam na presença dos deslocamentos, sendo o valor máximo atingido quando os deslocamentos são máximos, e a energia potencial, a única presente no sistema, uma vez que a velocidade será nula, será igual à energia de mola, ou restauradora, que até agora era usada para quantificar a energia potencial.

Equacionando:

$$
E_{p}=\sum_{i=1}^{n} k \delta^{2} / 2=\sum_{i=1}^{n} T_{i}=\sum_{i=1}^{n} F_{i} \delta_{i} / 2
$$

A energia cinética será obtida pela mesma conceituação anterior, apenas substituindo a integração pelo somatório, ou seja 


$$
E_{c}=\frac{\omega^{2}}{2} \int m x^{2} d z=\frac{\omega^{2}}{2} \sum_{i=1}^{n} m\left(\delta_{i}\right)^{2}
$$

Igualando as duas equaçōes anteriores, tira-se:

$$
\omega=\sqrt{\frac{\sum F_{i} \delta_{i}}{\sum m_{i}\left(\delta_{i}\right)^{2}}}
$$

Para trabalhar diretamente com os pesos e não com as massas, a expressão pode ser modificada para:

$$
\omega_{1}=\sqrt{\frac{g \sum F_{i} \delta_{i}}{\sum P_{i}\left(\delta_{i}\right)^{2}}}
$$

onde $\mathbf{P}_{\mathbf{i}}$ será o peso total concentrado em cada andar.

No caso do pórtico da figura seguinte, admitindo-se que o mesmo, devido às ações horizontais, deforme-se semelhante a uma viga em balanço, podese fazer, com bastante aproximação:

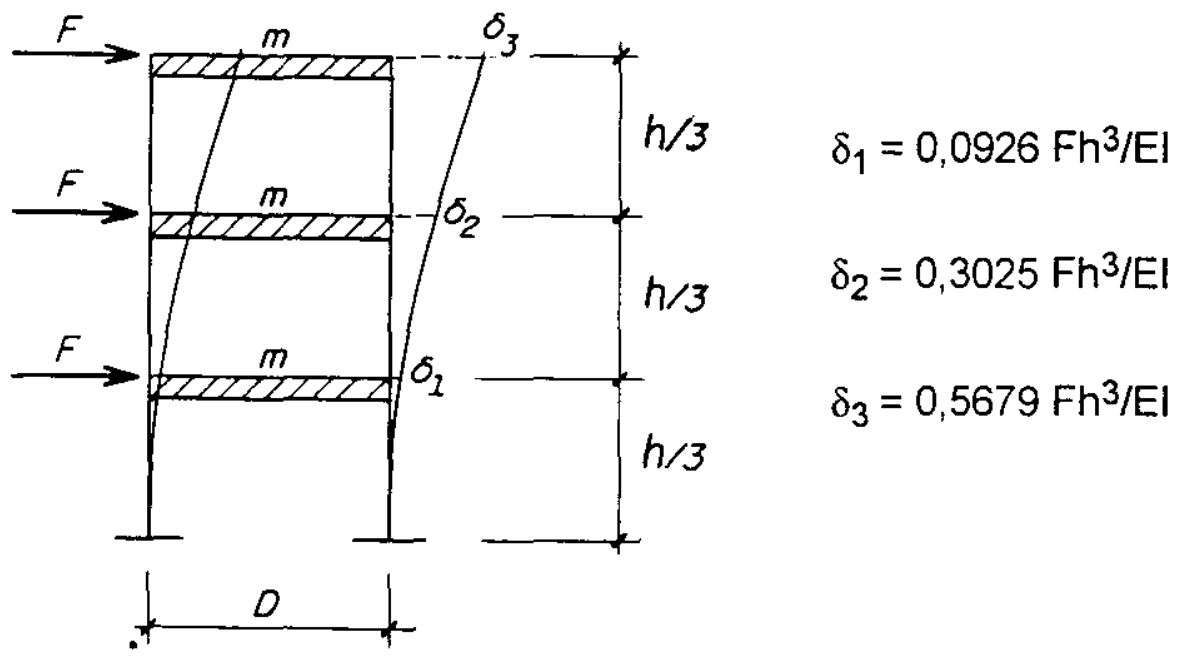

Figura 3.5 - Pórtico Deslocável

Encontrando-se:

$$
\omega=1,5096 \sqrt{\frac{\mathrm{El}}{\mathrm{Ph}^{3}}}
$$


No estudo da flexão costuma-se desprezar a contribuição do cortante na elástica das vigas. Entretanto, nos edifícios construídos com os fechamentos laterais executados quase que tão somente em alvenaria de tijolos, que podem oferecer resistênciá à deformaçōes por cisalhamento, podendo contribuir, deste modo, para o aumento da rigidez e consequentemente da frequência natural.

Quando for julgado conveniente ou mesmo necessário incorporar esta rigidez, pode-se fazer, uma vez que:

$$
d x=\frac{V \cdot d z}{\alpha A_{S} G}
$$

onde: $V=$ Esforço cortante na seção

$\alpha=$ Coeficiente de uniformização de tensōes (1,2 para seçōes retangulares).

$A_{S}=$ Área da seção

$\mathrm{G}=$ Módulo de elasticidade transversal da parede.

Para o pórtico da figura anterior: $A_{s}=\ell . t$

$\mathrm{t}=$ espessura da parede

$\mathrm{G} \cong 0,4 \mathrm{E}$

$\mathrm{dz}=\mathrm{h} / 3$

No primeiro andar ocorre: $\mathbf{V}=3 \mathrm{~F}$

Entrando com $1=\mathbf{t} \ell^{3} / 12$ e substituindo $\alpha: \delta_{1}=0,1736 \mathrm{Fh} \ell^{2} /$ El encontra-se:

$$
\delta_{1}=\frac{2,5 \mathrm{Fh}}{\alpha \ell \mathrm{tE}}
$$

No andar intermediário ocorre: $\mathbf{V}=2 \mathrm{~F}$ e do mesmo modo, a deformação devida ao cortante será:

$$
\delta_{2}=\delta_{1}+0,1157 \mathrm{Fh} \ell^{2} / \mathrm{El}=0,2893 \mathrm{Fh} \ell^{2} / \mathrm{El}
$$

No último andar, $\mathrm{V}=\mathrm{F}$ e a deformação será: $\delta_{3}=0,3472 \mathrm{Fh} \ell^{2} / \mathrm{El}$ 
Os deslocamentos ao nivel das lajes, considerando o efeito do momento e do cortante serão:

$$
\begin{aligned}
& \delta_{1 \mathrm{~T}}=0,0926 \frac{\mathrm{Fh}^{3}}{\mathrm{EI}}\left[1+1,8747\left(\frac{\ell}{\mathrm{h}}\right)^{2}\right] \\
& \delta_{2 \mathrm{~T}}=0,3025 \frac{\mathrm{Fh}^{3}}{\mathrm{EI}}\left[1+0,9564\left(\frac{\ell}{\mathrm{h}}\right)^{2}\right] \\
& \delta_{3 \mathrm{~T}}=0,5679 \frac{\mathrm{Fh}^{3}}{\mathrm{EI}}\left[1+0,6114\left(\frac{\ell}{\mathrm{h}}\right)^{2}\right]
\end{aligned}
$$

Variando-se a relação $\ell / h$ pode ser montado o seguinte quadro de resultados apenas com os coeficientes numéricos;

\begin{tabular}{|c|c|c|c|c|c|}
\hline$\ell / \mathbf{h}$ & $\boldsymbol{\delta}_{\mathbf{1 T}}$ & $\boldsymbol{\delta}_{\mathbf{2 T}}$ & $\delta_{\mathbf{3 T}}$ & $\boldsymbol{\omega}$ & $\begin{array}{c}\text { variação } \\
(\%)\end{array}$ \\
\hline 0,00 & 0,0926 & 0,3025 & 0,5679 & 1,5000 & - \\
\hline 0,10 & 0,0943 & 0,3054 & 0,5714 & 1,4453 & 3,78 \\
\hline 0,20 & 0,0995 & 0,3141 & 0,5818 & 1,4316 & 4,78 \\
\hline 0,30 & 0,1082 & 0,3285 & 0,5991 & 1,4096 & 6,41 \\
\hline 0,40 & 0,1204 & 0,3488 & 0,6235 & 1,3802 & 8,68 \\
\hline 0,50 & 0,1360 & 0,3748 & 0,6547 & 1,3450 & 11,53 \\
\hline 1,00 & 0,2662 & 0,5918 & 0,9151 & 1,1264 & 33,17 \\
\hline
\end{tabular}

Como pode ser observado, a relação $\ell / h$ começa a ganhar importância ao se aproximar da unidade. Para valores menores do que 0,5 quase em nada influencia os valores obtidos considerando apenas a resistência à flexão.

Vale também observar que o módulo de elasticidade transversal adotado foi o do aço ( $G \cong 0,385 E$ ) que, como se sabe, é quase dez vezes mais alto que o das alvenarias, o que diminui ainda mais a influência do esforço cortante.

Resumindo, a aplicação do método de Raleigh para a determinação do modo fundamental de vibração de uma estrutura, pode ficar restrito ao emprego da equação ( $3.3 .65 a$ ): 
Devido às flutuações da velocidade e das direções das rajadas, que são bastante aleatórias, o vento pode ainda provocar deslocamentos no sentido transversal do fluxo, que podem ser determinados pela expressão da norma NBR-6123, que as relaciona com os deslocamentos na direção do fluxo, da seguinte forma: $y_{i}=x_{i} / 3$

Por último, cabe ressaltar os efeitos causados por edificações situadas nas proximidades, que podem ser favoráveis ou desfavoráveis.

Os efeitos favoráveis são computados quando da escolha da categoria, que leva em conta a altura média das construçōes em volta. Esta escolha é feita quando da determinação do fluxo de escoamento pois, caso os obstáculos se estendam a uma grande distância, o fluxo pode ser turbulento, com coeficientes aerodinâmicos menores que os obtidos para fluxo laminar. Estas reduções são abordadas no item 6.5 da NBR-6123.

Como efeitos desfavoráveis podem ser citados:

a - Efeito Venturi - aceleramento do fluxo próximo da edificação, causado pela presença de dois ou mais obstáculos à barlavento. É dificil de quantificar sem uma simulação em túnel de vento.

b - Deflexão vertical - aceleramento do fluxo, junto à base da edificação causando fluxo negativo na parede de barlavento, também só quantificável por meio de simulações.

c - Turbulência de esteira - pode ocorrer em edificações situadas a sotavento de outras, com formação de vórtices que conduzem a uma grande flutuação das pressões localizadas, provocando variaçōes na força de sustentação do vento.

d - Galope - são oscilações transversais ao fluxo, que surgem devido às flutuaçōes das rajadas. Estas flutuaçōes aumentam com o aumento da velocidade do vento. As estruturas mais sensiveis à este efeito, são as mais esbeltas, leves e flexiveis.

e - Drapejamento - ocorre em estruturas muito esbeltas, caracterizando-se pelo acoplamento de vibrações em dois ou mais graus de liberdade, como por exemplo, translaçōes com rotações. 
f - Desprendimento cadenciado de vórtices - surgem principamente em edificações com saliências em formas de angulosidades. Este desprendimento pode introduzir vibraçōes transversais ao fluxo do vento. A velocidade crítica para este efeito é obtida pela expressão:

$$
V_{c r}=f \ell_{1} / 0,15
$$

sendo: $\quad f=$ frequencia natural da estrutura.

$\ell_{1}=$ largura da edificação perpendicaular ao fluxo

$0,15=$ constante, ou número de Strouhal.

$g$ - Excentricidades da força de arrasto - surgem quando a resultante do vento não passa pelo centro elástico da estrutura, devido à falta de simetria desta ou nas incidências não paralelas a nenhuma das faces, ou ainda devido a presença de obstáculos à sotavento. A NBR-6123 permite uma avalição da excentricidade por expressões da forma:

$e_{i}=k \cdot \ell$

sendo: $e_{i}=$ excentricidade em relação a uma face.

$k=$ coeficiente com valores:

0,075 - sem efeitos de vizinhança.

0,15 - com efeitos de vizinhança.

$\ell=$ largura da edificação para o sentido analisado.

h - Majoração dos coeficientes aerodinâmicos - devido à impossibilidade de quantificar cada efeito, sem uma simulação em túnel de vento, a norma apresenta no anexo 9 um fator de correção dos coeficientes, que no caso dos edifícios pode ser resumido como:

$$
F_{v}=1,0 \text { a } 1,3
$$

em função da relação s/d ser maior que 3,0 ou menor que a unidade, respectivamente. 
Sendo: $\quad F_{\mathrm{v}}=$ Fator que deve multiplicar $\mathrm{Ca}$ ou $\mathrm{Ce}$

$\mathrm{s}=$ afastamento entre duas edificações vizinhas

$d=$ menor dimensão entre: $b=$ lado menor da edificação ou

$0,5 \sqrt{a^{2}+b^{2}}=$ semi-diagonal da edificação

Em construções que vibram, mesmo sem afetar a segurança, podem acontecer indisposiçōes nos ocupantes, na forma de enjôo nos dias de forte ventania ou de ventos com frequências próximas da natural da estrutura. Esta percepção é função da amplitude, da frequência e da aceleração do movimento. A Norma NBR-6123, no item 9.5, fornece uma expressão que permite a determinação da aceleração máxima, dada por:

$$
a_{j}=\omega_{j}^{2} \delta_{j}=4 \pi^{2} f_{j}^{2} u_{j}<0,1 m / s^{2}
$$

onde: $\mathrm{f}_{\mathrm{j}}=$ frequência analisada

$u_{j}=$ deslocamento devido somente à resposta flutuante

Para efeito desta verificação pode ser admitido que esta amplitude seja excedida, em média, uma vez em cada dez anos, portanto, com velocidade menor que a de projeto, que pode ser excedida em média uma vez a cada 50 anos. Entretanto, a percepção da oscilação varia muito de uma pessoa para outra, ou seja, um movimento que para alguns é incômodo, para outros é quase imperceptivel.

Como não se sabe exatamente como se desencadeia este processo perceptivo dentro do ser humano, não é possivel afirmar que o mais importante seja a limitação da amplitude, da velocidade, da aceleração, ou da frequência. Deste modo, procura-se limitar um destes parâmetros, mantendo os demais dependentes daquele tomado como controle.

É usual utilizar como controle a aceleração do movimento, expressa em percentual da aceleração da gravidade, quando pode ser observado que a grande maioria da população reage da seguinte forma:

$$
\begin{aligned}
& a \leq 0,5 \% g \text { - movimento imperceptível } \\
& 0,5 \% \mathrm{~g}<a \leq 1,5 \% \mathrm{~g} \text { - perceptivel } \\
& 1,5 \% \mathrm{~g}<\mathrm{a} \leq 5 \% \mathrm{~g} \text { - incômodo } \\
& 5 \% \mathrm{~g}<\mathrm{a} \leq 15 \% \mathrm{~g} \text { - muito incômodo } \\
& \text { a }>15 \% g \text { - insuportável }
\end{aligned}
$$


Este valores explicam o limite adotado pela NBR-6123 que é de aproximadamente $1 \% \mathrm{~g}$, assegurando assim que não ocorram aceleraçōes além das perceptíveis à maioria dos usuários. Porém, esta limitação por si só não é suficiente, deve-se ter em vista também o deslocamento e o período da oscilação.

O limiar da percepção, segundo CHEN [ 12 ], em 50\% dos casos analisados, para acelerações da ordem de $1 \% \mathrm{~g}, 0,9 \% \mathrm{~g}$ e $0,5 \% \mathrm{~g}$, coincide com frequências de $0,07 \mathrm{~Hz} ; 0,1 \mathrm{~Hz}$ e $0,2 \mathrm{~Hz}$ respectivamente, observandose, portanto, que com o aumento da celeração o limiar da percepção ocorre para frequências mais baixas.

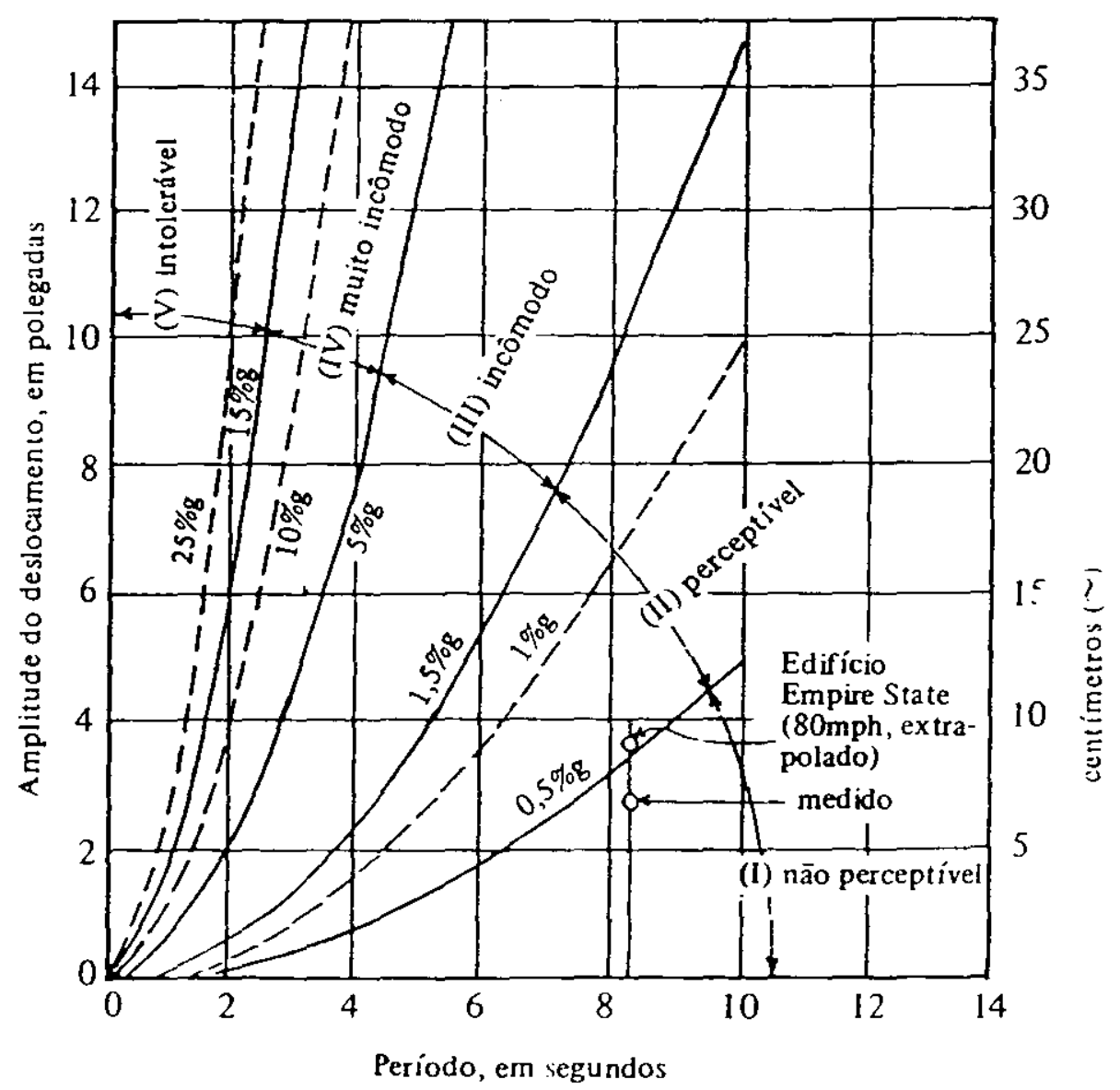

Figura 3.6 -Gráfico de Chang

A visualização da dependência entre a frequência e a aceleração, pode ser melhor apresentada, por meio do clássico gráfico desenvolvido por CHANG [ 12, 22 ] e apresentado na figura acima, onde constam as curvas das aceleraçōes limites, plotadas sobre as retas horizontais das amplitudes e as verticais dos períodos. 
Quanto ao conforto dos transeuntes junto à base da edificação, cabe comentar que, ocorrendo aumentos da velocidade devido aos efeitos de iteração, ( Venturi, deflexão vertical ou despreendimento de vórticos ), a velocidade final não deve ultrapassar a $10 \mathrm{~m} / \mathrm{s}(36 \mathrm{~km} / \mathrm{h})$, sendo um limite para o início de situações perigosas o valor de $15 \mathrm{~m} / \mathrm{s}(54 \mathrm{~km} / \mathrm{h})$.

Para evitar este aumento da velocidade podem ser utilizados diversos recursos, como uma área maior nos andares inferiores, colocação de marquise, mudança da orientação da construção ou, onde for possivel, evitar utilizar fachadas planas em edifícios isolados.

\section{4- OUTRAS AÇÕES}

As demais ações, como variações de temperatura, deformações dos materiais, fluência ou retração, não costumam, embora devessem, preocupar os projetistas uma vez que as suas implicaçōes costumam ser relativamente pequenas. Quanto às ações sísmicas e as devidas a neve, que praticamente não acontecem em nosso país, não costumam ser consideradas.

\section{5- EFEITOS DE SEGUNDA ORDEM}

$\mathrm{Na}$ determinação das solicitações devem ser levadas em conta, algumas características que nem sempre são contempladas pelos programas computacionais com maior difusão no mercado.

Uma destas características é o possivel desalinhamento dos perfis na sua fase de fabricação, onde as especificações usuais [ 2, 8 ], costumam limitar a relaçōes próximas de $1 / 1000$ do comprimento. Em uma viga, um encurvamento desta ordem pode e assim é descrito nas especificações, servir como contra-flecha, evitando assim um trabalho adicional de conformação.

Entretanto, em uma coluna pode dar origem a um momento adicional, em alguns casos de magnitude significativa, que pode inclusive conduzir a um estado limite último. 
Assim como estes desalinhamentos de fabricação, pequenas excentricidades nas ligações também podem introduzir momentos, semelhantes tanto em causa como em efeito.

A Norma NBR-8800 [ 8 ], assim como as demais especificaçōes, baseadas no método dos Estados Limites, já introduzem nos seus procedimentos de dimensionamento, estas limitações construtivas porém, dentro dos valores máximos recomendados. Caso o valor observado ultrapasse estes limites, a barra deve ser devolvida à sequência de fabricação para corrigir as distorçōes observadas.

Quando não for possivel corrigir ou substituir a barra defeituosa, deve a mesma ser submetida a uma análise que leve em conta as imperfeições observadas e caso possam surgir pontos onde as tensões ou a estabilidade fiquem comprometidas, deve-se procurar reforçar estes pontos.

Outra forma de aparecimento do efeito de segunda ordem, encontrase nas barras onde a flecha devida à flexão, ou uma deformação de montagem, é ampliada com a introdução de uma força de compressão.

Entretanto, as deformaçōes e suas ampliaçōes, assim como as excentricidades de projeto e as deformações devidas aos processos de fabricação, podem ser tratadas segundo o mesmo modelo matemático, que segundo TIMOSHENKO [ 39 ] pode ser representado como:

$$
\mu=\frac{1}{1-\frac{P}{P_{e}}}
$$

onde: $\mu=$ fator de amplificação de flechas

$P=$ força de compressão atuante

$P_{e}=$ força crítica de flambagem em regime elástico (Euler)

Vale lembrar que a força crítica $\mathbf{P}_{\mathbf{e}}$ deve ser calculada entrando-se com o comprimento de flambagem da barra, determinado para o tipo de estrutura, se deslocável ou indeslocável, se ocorre ou não a flambagem simultânea das outras colunas que compõe a estrutura e muito importante, se todas as forças aplicadas nas colunas mantém-se proporcionais entre si até o instante do pressumivel colapso.

Caso todas estas hipóteses não sejam atendidas, pode ocorrer um grande desvio do valor calculado para o valor real de $\mathbf{P}_{\mathbf{e}}$. 
A NBR-8800 apresenta um ábaco, retirado do AISC, que permite determinar o comprimento de flambagem levando em conta as condições de extremidade da barra e a rigidez de cada nó. Neste ábaco, apresentado na figura 18 do Anexo I, é possivel considerar a contribuição das vigas que concorrem nos nós, bem como a continuidade do pilar.

A amplificação das deformaçōes causa também um aumento nas solicitações existentes. Nos elementos flexo-comprimidos as solicitaçōes de flexão serão influenciadas pela presença da compressão. Ainda como mostra TIMOSHENKO [ 39 ], a solução exata, tanto da elástica como das solicitaçōes em elementos flexo-comprimidos, possui uma formulação complexa e bastante trabalhosa.

A formulação utilizada pelo AISC - LRFD, é bem mais simples e conduz a resultados que não diferem em muito dos exatos.

Nesta formulação, a amplificação do momento pode ser quantificada pelo coeficiente $B_{1}$, escrito como:

$$
\mathrm{B}_{1}=\mu \mathrm{Cm}
$$

onde: $\mu=1 /\left(1-P / P_{e}\right)=$ fator de amplificação das flechas.

$\mathrm{Cm}=1+\psi \alpha=$ fator de equivalencia de carregamentos

sendo: $\alpha=P / P_{e}$

e

$$
\psi=\frac{P_{\mathrm{e}} \delta_{0}}{M_{0}}-1
$$

Na última expressão, $\delta_{0}$ e $\mathbf{M}_{\mathbf{0}}$ são determinados com as condições iniciais, em teoria de primeira ordem.

Este comportamento de segunda ordem, pode ser melhor visualizado na figura seguinte, que permite escrever:

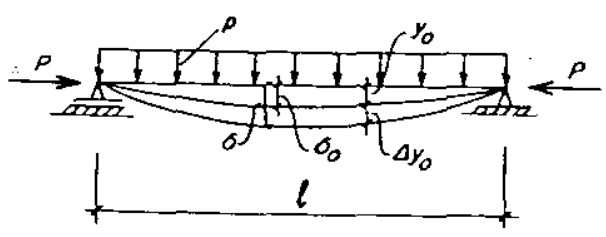

Figura 3.7 - Viga-coluna com ação distribuida uniformemente 
$y_{0}=$ deslocamento de 1a. ordem

$\Delta \mathrm{y}_{0}=$ deslocamento de 2a. ordem

$y=y_{0}+\Delta y_{0}=$ deslocamento total

Chamando de $\delta_{0} 0$ deslocamento máximo de primeira ordem e de $\delta \circ$ deslocamento total, formado pelo de primeira mais o de segunda ordem, pode-se escrever, com boa aproximação:

$$
\begin{aligned}
y_{0} & =\delta_{0} \operatorname{sen} \pi \times / \ell \\
\text { e: } \quad & y=\delta \operatorname{sen} \pi \times / \ell
\end{aligned}
$$

Derivando duas vezes as expressões anteriores:

$$
\begin{aligned}
& y^{\prime \prime}{ }_{0}=-\delta_{0} \frac{\pi^{2}}{\ell^{2}} \operatorname{sen} \pi x / \ell=-M_{0} / E I \\
& y^{n}=-\delta \frac{\pi^{2}}{\ell^{2}} \operatorname{sen} \pi u / \ell=-M / E I=-\frac{M_{0}+P \cdot y}{E I}
\end{aligned}
$$

Substituindo $y_{0}^{\prime \prime}$ e y em $y^{\prime \prime}$ :

$$
y^{\prime \prime}=-\delta \frac{\pi^{2}}{\ell^{2}} \operatorname{sen} \frac{\pi x}{\ell}=\delta_{0} \frac{\pi^{2}}{\ell^{2}} \operatorname{sen} \frac{\pi x}{\ell}-\frac{P}{E l} \delta \operatorname{sen} \frac{\pi x}{\ell}
$$

Encontra-se:

$$
\delta=\frac{\delta_{0}}{1-\mathrm{P} / \mathrm{P}_{\mathrm{e}}}=\mu \delta_{\mathrm{o}}
$$

E o momento máximo na viga pode ser escrito como:

$$
M_{\text {máx }}=M_{o}+P \delta=M_{0}+P \mu \delta_{o}=\mu C_{m} M_{0}
$$

Determinando-se portanto:

$$
\mu C_{m}=1+\frac{P \mu \delta_{0}}{M_{0}}=\mu\left(\frac{1}{\mu}+\frac{\delta_{0} P}{M_{0}}\right)
$$


Multiplicando e dividindo o segundo termo por $\mathbf{P}_{\mathbf{e}}$ e substituindo $\boldsymbol{\mu}$ pela sua expressão, chega-se a:

$$
C_{m}=1-\frac{P}{P_{e}}+\frac{P}{P_{e}} \cdot \frac{\delta_{0} P_{e}}{M_{0}}=1+\frac{P}{P_{e}}\left(\frac{\delta_{0} P_{e}}{M_{0}}-1\right)=1+\frac{P}{P e} \psi
$$

Portanto: $C_{m}=1+\psi \alpha$

Substituindo-se valores encontra-se:

$$
\begin{aligned}
& \delta_{0}=5 \mathrm{p} \ell^{4} / 384 \mathrm{El} \\
& \mathrm{M}_{0}=\mathrm{p} \ell^{2} / 8 \\
& \mathrm{P}_{\mathrm{e}}=\pi^{2} \mathrm{El} / \ell^{2} \\
& \psi=0,028
\end{aligned}
$$

Atribuindo-se valores à relação $\mathbf{P} / \mathbf{P}_{\mathbf{e}}$ encontra-se os valores de $\mathbf{C}_{\mathbf{m}} \mathbf{e}$ $B_{1}$ que constam do quadro seguinte:

\begin{tabular}{|r|r|r|r|r|r|r|r|r|r|}
\hline$P_{P} P_{e}$ & 0,0 & 0,1 & 0,2 & 0,3 & 0,4 & 0,5 & 0,6 & 0,7 & 0,8 \\
\hline $\mathbf{C}_{\boldsymbol{m}}$ & 1,0 & 1,003 & 1,006 & 1,008 & 1,011 & 1,014 & 1,017 & 1,020 & 1,023 \\
\hline $\mathbf{B}_{1}$ & 1,0 & 1,114 & 1,257 & 1,441 & 1,685 & 2,028 & 2,543 & 3,400 & 5,112 \\
\hline
\end{tabular}

Neste caso, a NBR-8800 e o AISC recomendam adotar $C_{m}=1,0$

Para uma viga também biapoiada, porém submetida a uma força $\mathbf{F}$ concentrada, aplicada no meio do vão e a força $P$ de compressão, utilizando o mesmo procedimento anterior encontram-se os valores de primeira ordem, ou iniciais abaixo:

$$
\begin{aligned}
\delta_{0} & =\mathrm{F} \ell^{3} / 48 \mathrm{El} \\
\mathrm{M}_{0} & =\mathrm{F} \ell / 4 \\
\mathrm{P}_{\mathrm{e}} & =\pi^{2} \mathrm{El} / \ell^{2} \\
\psi & =-0,1775
\end{aligned}
$$

Do mesmo modo, atribuindo-se valores à relaçāo $\mathbf{P} / \mathrm{P}_{\mathbf{e}}$ encontra-se os valores de $C_{m}$ e $B_{1}$ para este caso de carregamento, que estão apresentados no quadro seguinte: 


\begin{tabular}{|r|r|r|r|r|r|r|r|r|r|}
\hline $\mathbf{P} / \mathbf{P}_{\mathbf{e}}$ & 0,0 & 0,1 & 0,2 & 0,3 & 0,4 & 0,5 & 0,6 & 0,7 & 0,8 \\
\hline $\mathbf{C}_{\mathbf{m}}$ & 1,0 & 0,982 & 0,965 & 0,947 & 0,929 & 0,911 & 0,894 & 0,876 & 0,858 \\
\hline $\mathbf{B}_{\mathbf{1}}$ & 1,0 & 1,091 & 1,206 & 1,353 & 1,538 & 1,823 & 2,235 & 2,920 & 4,290 \\
\hline
\end{tabular}

Também neste caso é recomendado adotar $C_{m}=1,0$, na falta de uma análise mais precisa.

Para uma viga simplesmente apoiada, solicitada por um momento aplicado em um dos apoios e a força de compressão $P$, como ilustra a figura abaixo, torna-se necessário determinar inicialmente o ponto onde ocorre 0 máximo deslocamento $\mathrm{y}_{\mathrm{o}}$.

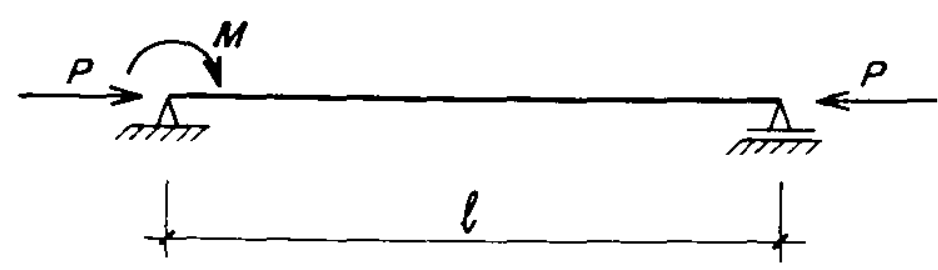

Figura 3.8 - Viga-coluna com momento aplicado

Este ponto localiza-se a uma distancia de 0,4227£ do apoio em que é aplicado o momento $\mathbf{M}$, e o valor do momento neste ponto é de $0,5774 \mathrm{M}$.

Portanto:

$$
\begin{aligned}
& \delta_{0}=0,0642 \mathrm{M} \ell^{2} \\
& \mathrm{M}_{0}=0,5774 \mathrm{M} \\
& \psi=0,0966
\end{aligned}
$$

Para esta situação, o AISC recomenda $\psi=0$ e $C_{m}=0,6$.

Para a mesma viga, porém com momentos $\mathbf{M}_{\mathbf{1}}$ e $\mathbf{M}_{\mathbf{2}}$ aplicados nos apoios, pode ser assumido que o deslocamento máximo ocorra a $\mathbf{0 , 4} \ell$ do apoio onde está aplicado o momento de maior valor.

Convencionarido que: $M_{2}>M_{1}$ chega-se a:

$$
M_{0}=0,6 M_{2}+0,4 M_{1}
$$

colocando $M_{2}$ em evidência: $\quad M_{0}=M_{2}\left(0,6+0,4 M_{1} / M_{2}\right)$ 
As normas recomendam para esta situação de carregamento:

$$
C_{m}=0,6+0,4 M_{1} / M_{2}
$$

sendo $\mathbf{M}_{2} \circ$ maior dos momentos aplicados e a relação $\mathbf{M}_{\mathbf{1}} / \mathbf{M}_{2}$ positiva quando os dois momentos possuirem sentidos contrários, ou seja provocam curvatura simples e negativa quando os dois momentos provocaem curvatura reversa.

A NBR-8800 limita o valor de $C_{m}$, obtido pela expressão anterior, a ser maior ou igual a $\mathbf{0 , 4}$ porém o AISC não impōe limitação.

Outra divergência entre as duas normas ocorre na resolução das estruturas deslocáveis.

A NBR-8800 fornece valores de $C_{m}$ para estas estruturas, lembrando que caso seja feita análise de segunda ordem, estas devem ser consideradas como indeslocáveis. Esta recomendaçäo deixa a critério do calculista a decisão de realizar ou não a análise de segunda ordem.

O AISC-LRFD nāo fornece valores de $C_{m}$ para as estruturas deslocáveis, apenas o AISC-ASD o faz, ficando bem claro no LRFD, que uma análise nos estados limites deve implicar na aplicação da teoria de segunda ordem, independente do grau de flexibilidade da estrutura.

Nas duas normas, para as barras de estruturas indeslocáveis, encontra-se a recomendação dos seguintes valores de $C_{m}$, caso não se faça uma análise mais precisa:

1- Barras com forças aplicadas entre os apoios:

Com os dois apoios engastados: $C_{m}=0,85$

Nos demais casos: $C_{m}=1,0$

2- Barras sem forças aplicadas entre os apoios:

$$
C_{m}=0,6+0,4 M_{1} / M_{2}
$$

Com as limitações e interpretações já comentadas.

A NBR-8800 e o AISC-ASD recomendam que nas barras das estruturas deslocáveis, sem análise de segunda ordem, seja aplicado um fator $C_{m}=0,85$.

Outra observação importante deve ser feita quanto às alterações dos momentos das extremidades das vigas engastadas. Embora as normas não costumem indicar fatores de correção, análises mais exatas do problema, como as realizadas por TIMOSHENKO [ 39 ] e IWANKI [ 23 ], mostram como estes momentos variam quando varia a relação $P / P_{e}$. 
Estas variações estão sintetizadas no quadro abaixo.

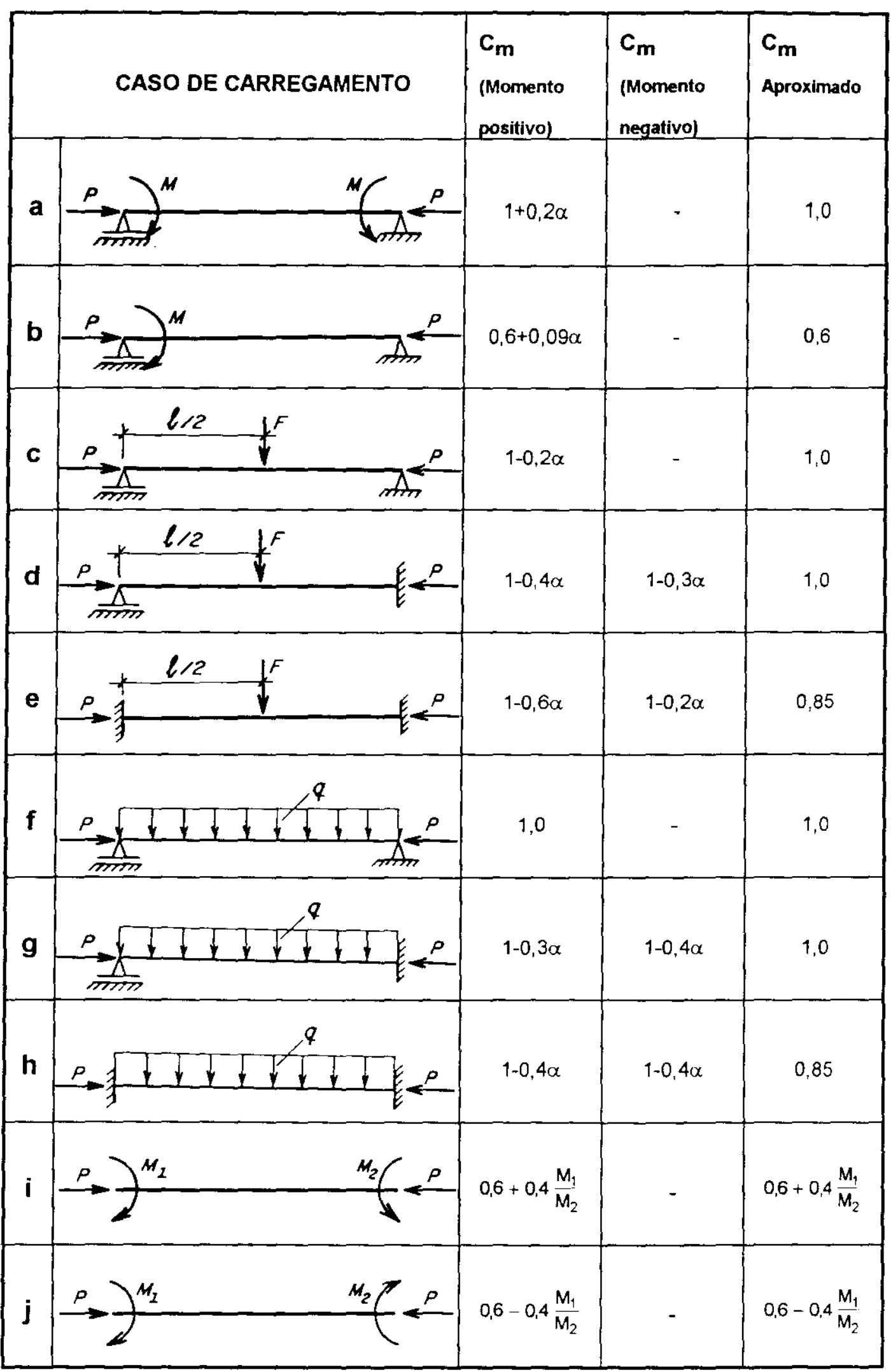

Lembrando que: $\alpha=\mathbf{P} / \mathbf{P}_{\mathbf{e}}$ 
Deste modo é possivel determinar, com razoável precisāo, o fator $\mathbf{B}_{\mathbf{1}}$ que leva em conta o efeito de segunda ordem devido às imperfeiçōes inicais e excentricidades na aplicação das forças, conhecido como efeito $P-\delta$, como já escrito:

$$
B_{1}=\mu C_{m}
$$

Ainda segundo o AISC-LRFD, todas as estruturas devem ser analisadas em teoria de segunda ordem, que acrescenta aos efeitos da primeira ordem, o efeito das açōes verticais na presença dos deslocamentos provocados pelas açōes horizontais. Este é o efeito denominado de P-delta ( $P-\Delta$ ), sobre o qual muito se pesquisou, teórica e experimentalmente.

Este tópico também está contido na NBR-8800, no seu anexo L, que permite a avaliação deste efeito por meio do método conhecido como da força lateral equivalente. Quando, na determinação das solicitações for empregado um programa que faz a análise em segunda ordem, este tópico já estará embutido nos resultados finais e a estrutura para efeito da norma passa a ser identificada como indeslocável.

O método da força lateral equivalente, que é apenas um entre os diversos existentes, pode ser facilmente compreendido a partir das condições de equilíbrio da estrutura, na configuração deslocada.

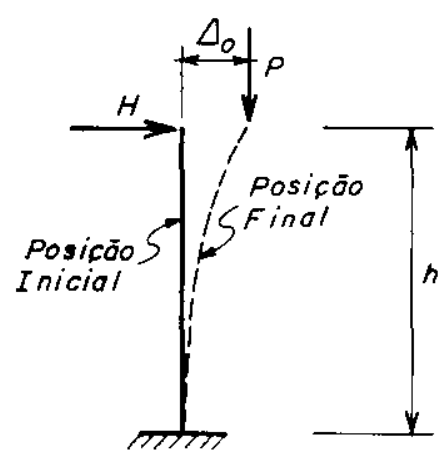

Figura 3.9 - Pilar sob ações combinadas

Exemplificando, seja o pilar representado na figura acima onde, em presença do deslocamento horizontal provocado pela força $\mathrm{H}$ é aplicada a força $\mathbf{P}$. Na posição de inicial, o momento na base é notificado como:

$$
M_{0}=H_{0} h
$$


Na posição deslocada este mesmo momento será:

$$
M_{0}=H_{0} h+P \Delta_{0}
$$

O incremento do momento, dado pela parcela $\mathbf{P} \Delta_{\mathbf{0}}$ acarretará um incremento no valor do deslocamento $\Delta_{\mathbf{0}}$, e o pilar atingirá o equilíbrio em uma posição, onde o momento final será expresso em função do deslocamento também final $\Delta_{u}$, ou seja:

$$
M_{F}=H_{0} h+P \Delta_{u}
$$

Como é um tanto complicado resolver o modelo matemático que conduz diretamente à posição de equilíbrio, utiliza-se o sistema de incrementos sucessivos de solicitações, até que 0 incremento de deslocamento, obtido em uma determinada iteração, pouco ou quase nada difira do incremento obtido na iteração anterior.

No caso do processo em discussão, o incremento inicial $\mathbf{P} \Delta_{\mathbf{o}}$ é assumido como equivalente a um binário fictício determinado como:

$$
\Delta H_{0} \cdot h=P \cdot \Delta_{0}
$$

Sendo $\Delta H_{o}$ denomindada de força fictícia. Somando $\Delta H_{o}$ ao valor inicial de $H_{0}$, encontra-se $H_{1}$ que, por sua vez, permite calcular o novo deslocamento $\Delta_{1}$ que conduz à determinação de um novo incremento, $\Delta \mathbf{H}_{1}$ a ser somado à ação horizontal $H_{0}$, prosseguindo-se assim, até que a diferença entre os incrementos $\Delta_{i+1}$ e $\Delta_{i}$ torne-se desprezivel em presença dos valores já obtidos nas iteraçōes anteriores.

Estendendo o conceito aplicado ao pilar da figura anterior, para uma estrutura com diversos andares, como o mostrado na figura seguinte, determina-se inicialmente os deslocamentos provocados pela força horizontal $\mathbf{H}_{\mathbf{o}}$ em teoria de primeira ordem.

Com estes deslocamentos calculam-se as forças fictícias em cada andar, por uma expressão similar à equação (3.5.4b), notificando-as como $\overline{\mathrm{V}}_{\mathrm{i}}$, ou seja:

$$
\bar{V}_{i}=\frac{\sum P_{i}}{h} \Delta_{i}
$$


A seguir calculam-se as resultantes destas forças para todos os pisos pela expressão:

$$
\Delta H_{i}=\bar{V}_{(i-1)}-\bar{V}_{i}=\frac{\sum P_{i}}{h}\left(\delta_{(i+1)}-\delta_{i}\right)
$$

Sendo $\mathbf{V}_{\mathbf{i}}$ a força fictícia que atua no andar $\mathbf{i}$ e $\Delta \mathbf{H}_{\mathbf{i}}$ a resultante que atua no nível do piso $\mathbf{i}$, lembrando também que $\Sigma \mathbf{P}_{\mathbf{i}}$ representa o somatório de todas as forças aplicadas nos pisos superiores, até inclusive o piso i e das forças aplicadas a pilares que eventualmente não façam parte do sistema de enrijecimento horizontal.

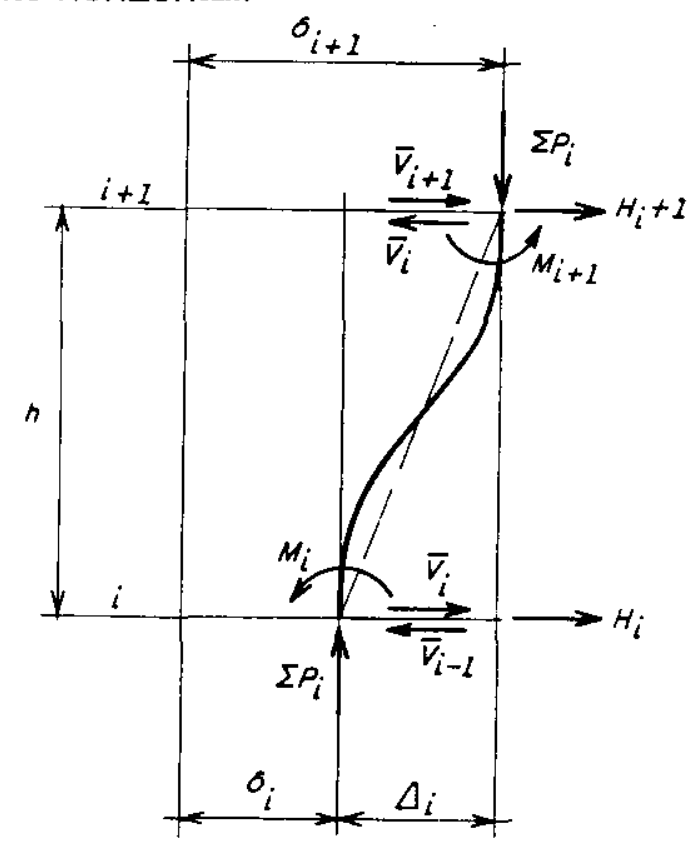

Figura 3.10 - Pilar Genérico em Análise não Linear

A força total $\mathbf{H}_{\mathbf{i}}=\mathbf{H}_{\mathbf{0}}+\Delta \mathbf{H}_{\mathbf{i}}$ aplicada a estrutura na sua posição inicial, provocará deslocamentos $\Delta_{\mathbf{i}}$, maiores que os anteriores, que permitirão uma nova iteração, com a repetição dos passos já descritos.

$O$ processo pode ser interrompido quando a diferença entre os deslocamentos de um mesmo andar, obtidos em duas iterações sucessivas, for menor que um valor pré-estabelecido, ou então não mais significativo.

Nas estruturas usuais não costuma ser necessário mais do que duas iterações, para que a diferença entre os deslocamentos se aproxime de zero.

Neste caso a rigidez horizontal da estrutura está convenientemente escolhida. 
Caso esta diferença pareça não tender a zero, ou então tenda muito lentamente, pode ser necessário aumentar a rigidez horizontal da estrutura.

Evidentemente 0 efeito P- $\Delta$ amplia os deslocamentos $e$ as deformações de primeira ordem é consequentemente, também as solicitaçōes.

O AISC-LRFD apresenta o mesmo procedimento, porém com algumas alteraçöes nas equações constitutivas. Para verificar qual 0 embasamento deste procedimento, retorna-se à figura anterior e admitindose que a posição deslocada seja a de equilíbrio final, pode ser retirado.

$$
\Delta_{\mathrm{i}}=\delta_{\mathrm{i}+1}-\delta_{\mathrm{i}}
$$

onde $\Delta_{\mathrm{i}}$ é o deslocamento total, de segunda mais o de primeira ordem.

Do mesmo modo é possivel escrever:

$$
B_{2}\left(M_{i}+M_{i+1}\right)=H_{i} h+\sum P_{i} \Delta_{i}
$$

Como em teoria de primeira ordem $\Delta H=0$, logo:

$$
M_{i}+M_{i+1}=H_{0} h
$$

Sendo $B_{2}$ o fator de amplificação devido à segunda ordem, que pode ser determinado apenas substituindo a equação de equilibrio da primeira ordem (3.5.5d) na equação da segunda ordem ( $3.5 .5 \mathrm{c}$ ), obtendo-se:

$$
\mathrm{B}_{2}=1+\frac{\sum \mathrm{P}_{\mathrm{i}}}{\mathrm{H}_{0} \mathrm{~h}} \Delta_{\mathrm{i}}
$$

A força lateral equivalente ou força total, pode ser escrita como:

$$
H_{i u}=H_{i 0}+\Delta H_{i u}=H_{0}+\frac{\sum P_{i}}{h} \Delta_{i u}
$$

Admitindo-se que a estrutura continue em regime elástico linear ( a não linearidade deve ser geométrica ) pode-se relacionar os deslocamentos de primeira ordem aos de segunda, por meio de um coeficiente de proporcionalidade $\boldsymbol{k}$ determinado como:

$$
k=H_{i} / \Delta_{i}
$$


que permite escrever:

$\mathrm{H}_{\mathrm{i}}=\mathrm{k} \cdot \Delta_{\mathrm{i}}$

ou

$\Delta_{\mathrm{i}}=\mathrm{H}_{\mathrm{i}} / \mathrm{k}$

portanto:

$\mathrm{H}_{\mathrm{iu}}=\mathrm{k} \cdot \Delta_{\mathrm{iu}}$

ou

$\Delta_{\mathrm{iu}}=\mathrm{H}_{\mathrm{iu}} / \mathrm{k}$

que, introduzidas na equação da força lateral equivalente (3.5.6a) determinam:

$$
H_{i u}=k \Delta_{i o}+\frac{\sum P_{i} \Delta_{i u}}{h_{i}}
$$

ou, arranjando em $\Delta_{\mathbf{i u}}$ :

$$
\Delta_{i u}=\frac{\Delta_{i 0}}{1-\frac{\sum P_{i} \Delta_{i o}}{H_{i 0} h_{i}}}
$$

que substituido na expressão de $\mathbf{B}_{\mathbf{2}}$ ( 3.5 .6 ) conduz à seguinte equação:

$$
\mathrm{B}_{2}=\frac{1}{1-\frac{\sum \mathrm{P}_{1} \Delta_{\mathrm{io}}}{\mathrm{H}_{\mathrm{jo}} h_{\mathrm{i}}}}
$$

Pela maneira como pode ser determinado o fator $\mathbf{B}_{\mathbf{2}}$, concluí-se que o processo é o mesmo apresentado na NBR-8800, apenas não é mais por um procedimento iterativo.

O AISC-LRFD na verdade apresenta duas opções na formulação de $\mathbf{B}_{2}$, que são:

$$
B_{2}=\frac{1}{1-\frac{\sum P_{u}}{\sum P_{e}}}
$$

e

$$
\mathrm{B}_{2}=\frac{1}{1-\sum \mathrm{P}\left(\frac{\Delta_{\mathrm{oh}}}{\sum \mathrm{HL}}\right)}
$$

onde: $\Sigma P=$ Somatório das forças de compressão, em valores nominais, que atuam no andar. 


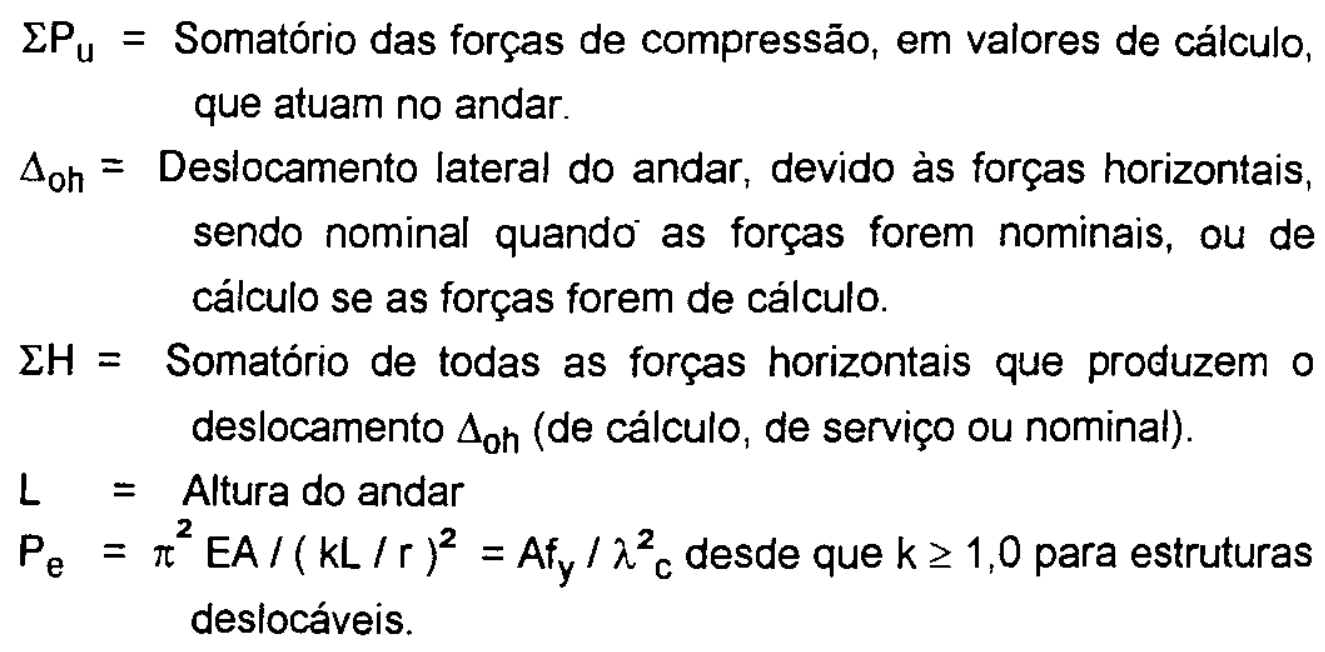

Como pode ser observado, a equação ( 3.5 .9 ) é uma generalização da expressão de $\mu$ ( fator de amplificação das flechas ), para estruturas sem ações horizontais consideráveis e a equação ( 3.5 .10 ) é a mesma definida pelo procedimento estudado, apenas com índices mais simploes.

Deste modo, o momento total final em teoria de segunda ordem, ainda segundo o AISC-LRFD, pode ser equacionado como:

$$
M_{u}=B_{1} M_{n t}+B_{2} M_{\ell t}
$$

Onde: $M_{n t}=$ momento atuante, de cálculo, em teoria de primeira ordem para estruturas indeslocáveis ( $\mathrm{nt}=$ no translation), submetidas apenas a ações verticais.

$M_{\ell t}=$ momento atuante, de cálculo, resultante das ações que produzem somente deslocamentos laterais $(\ell t=$ lateral translation ).

A grande dúvida na aplicação das duas normas, é sobre a necessidade de realizar a análise de segunda ordem. A NBR-8800 deixa esta decisão a critério do projetista, O AISC-LRFD, pelo contrário, sugere que todas as estruturas devem ser submetidas a esta análise, ou ao procedimento aproximado contido no seu texto, que já foi discutido.

Entretanto, a prática da engenharia tem mostrado que as estruturas submetidas a ações laterais, tem seus deslocamentos horizontais de primeira ordem, ampliados devido ao efeito de segunda ordem mas, que em muitos casos esta ampliação não chega a ser significativa, ficando ao redor de 5 a $10 \%$ dos valores obtidos em primeira ordem. 
Para estruturas analisadas em regime elástico, parece ser suficiente limitar os deslocamentos horizontais aos valores recomendados nas normas, que conduzem a estruturas com rigidez suficiente para não se tornarem susceptiveis de majorações significativas, quando submetidas a análise de segunda ordem.

Exemplificando, para a estrutura indeslocável, esquematizada na figura seguinte, considerando-a perfeitamente elástica e não sujeita a instabilidades locais, obtém-se os deslocamentos e solicitações, em primeira e em segunda ordem, apresentados no quadro abaixo:

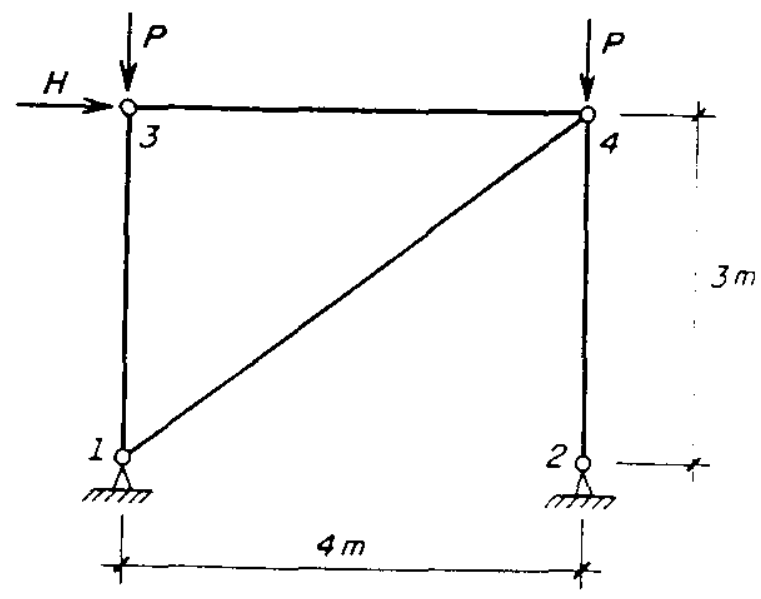

Materiais:

Colunas: CS $250 \times 52$

Viga: VS $400 \times 49$ Diagonal: $A=5 \mathrm{~cm}^{2}$ Aço ASTM A36/66 $P=500 \mathrm{kN}$ $\mathrm{H}=50 \mathrm{kN}$

Figura 3.11 - Estrutura Indeslocável

\begin{tabular}{|l|l|l|c|}
\cline { 2 - 4 } \multicolumn{1}{c|}{} & $\begin{array}{l}\text { Em teoria de } \\
\text { primeira } \\
\text { ordem }\end{array}$ & $\begin{array}{l}\text { Em teoria de } \\
\text { segunda } \\
\text { ordem }\end{array}$ & $\begin{array}{c}\text { Majoração } \\
\text { (\%) }\end{array}$ \\
\hline $\begin{array}{l}\text { Deslocamento } \\
\text { horizontal do nó 3 }\end{array}$ & $0,386 \mathrm{~cm}$ & $0,398 \mathrm{~cm}$ & 2,47 \\
\hline $\begin{array}{l}\text { Solicitação na } \\
\text { coluna 2-4 }\end{array}$ & $-537,5 \mathrm{kN}$ & $-538,488 \mathrm{kN}$ & 0,18 \\
\hline $\begin{array}{l}\text { Solicitação na } \\
\text { diagonal 1-4 }\end{array}$ & $62,5 \mathrm{kN}$ & $64,148 \mathrm{kN}$ & 2,64 \\
\hline
\end{tabular}

Como pode ser observado, as majoraçōes não ultrapassam $3 \%$ dos valores da primeira ordem, porém a relação entre o deslocamento horizontal e a altura $(\delta / L)$ é de $1 / 617$, o que confirma ser a estrutura suficientemente rigida para não apresentar efeitos de segunda ordem significativos. 
Verificando agora quais valores seriam obtidos com a aplicação do processo aproximado contido na NBR-8800, pode-se fazer:

$$
\begin{aligned}
& \Delta_{0}=H_{T} \ell_{d}^{3} / \ell^{2} E A_{d}=0,381 \mathrm{~cm} \\
& \Delta H_{0}=\sum P \Delta_{0} / \mathrm{h}=1,27 \mathrm{kN} \\
& H_{1}=H_{0}+\Delta H_{0}=51,27 \mathrm{kN} \\
& \Delta_{1}=0,391 \mathrm{~cm} \\
& \Delta_{1}=1,303 \mathrm{kN} \\
& H_{2}=51,303 \mathrm{kN} \\
& \Delta_{2}=0,391 \mathrm{~cm}=\Delta_{1}
\end{aligned}
$$

Ocorrendo uma majoração de $2,62 \%$ no deslocamento lateral.

As solicitações finais nas barras serão: coluna $2-4: \mathrm{N}=-538,475 \mathrm{kN}$ e na diagonal 1- 4: $M=64,124 \mathrm{kN}$ que são praticamente coincidentes com os obtidos na análise "exata".

Para uma estrutura deslocável, como a da figura seguinte encontra-se:

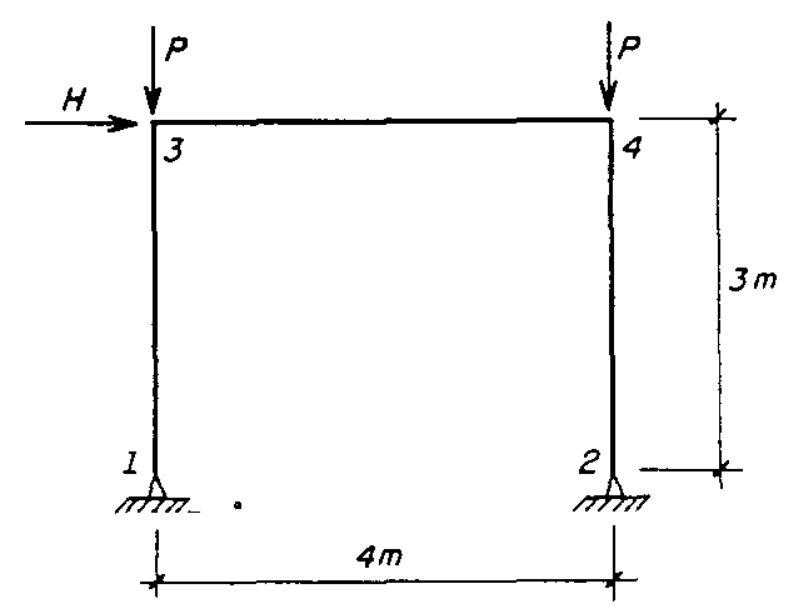

Materiais:

Colunas: CVS $350 \times 73$

Viga: VS $550 \times 64$

Aço ASTM A-36

$P=500 \mathrm{kN}$

$\mathrm{H}=50 \mathrm{kN}$

Figura 3.12 - Estrutura Deslocável 


\begin{tabular}{|l|l|l|c|}
\cline { 2 - 4 } \multicolumn{1}{c|}{} & $\begin{array}{l}\text { Em teoria de } \\
\text { primeira } \\
\text { ordem }\end{array}$ & $\begin{array}{l}\text { Em teoria de } \\
\text { segunda } \\
\text { ordem }\end{array}$ & $\begin{array}{c}\text { Majoração } \\
(\%)\end{array}$ \\
\hline $\begin{array}{l}\text { Deslocamento, } \\
\text { horizontal do nó 3 }\end{array}$ & $0,718 \mathrm{~cm}$ & $0,725 \mathrm{~cm}$ & 0,82 \\
\hline $\begin{array}{l}\text { Momento na } \\
\text { coluna 2-4 }\end{array}$ & $7478,565 \mathrm{kN}$ & $7854,113 \mathrm{kN}$ & 5,02 \\
\hline $\begin{array}{l}\text { Compressão na } \\
\text { coluna 2-4 }\end{array}$ & $-537,500 \mathrm{kN}$ & $-539,376 \mathrm{kN}$ & 0,35 \\
\hline
\end{tabular}

Nesta estrutura, a relação entre o deslocamento horizontal e a altura é de 1/418, que está próxima do limite recomendado que é de $1 / 400$, podendo-se observar que a amplificação no momento da coluna ficou próximo de $5 \%$.

Entretanto, o anexo C da NBR-8800 prescreve também que esta relação para pisos sucessivos, quando os elementos de fechamentos não absorverem os deslocamentos da estrutura, deve ser limitada a 1/500. Desta forma o pórtico em análise deveria ter a sua rigidez aumentada, reduzindo o deslocamento horizontal e, consequentemente a influência do efeito $\mathbf{P}-\Lambda$.

Aplicando o procedimento da NBR-8800, encontram-se:

$$
\begin{aligned}
& \Delta_{0}=0,718 \mathrm{~cm} \\
& \Delta \mathrm{H}_{0}=\sum \mathrm{P} \Delta_{0} / \mathrm{h}=2,393 \mathrm{kN} \\
& \Delta_{1}=0,752 \mathrm{~cm} \\
& \Delta \mathrm{H}_{1}=2,507 \mathrm{kN} \\
& \Delta_{2}=0,754 \mathrm{~cm} \\
& \Delta_{2}=2,513 \mathrm{kN} \\
& \Delta_{3}=0,754=\Delta_{2}
\end{aligned}
$$


Ocorrendo, por este procedimento, uma majoração de $5,01 \%$ no deslocamento horizontal.

Nas solicitações da coluna 2-4 encontram-se: $M=7855,515 \mathrm{kN} . \mathrm{cm}$ e $\mathrm{N}=539,385 \mathrm{kN}$ que também quase coincidem com os valores obtidos com a análise "exata".

Pelo procedimento do AISC-LRFD, encontram-se:

ou então:

$$
\mathrm{B}_{2}=\frac{1}{1-\sum \mathrm{P} \frac{\Delta_{0}}{\mathrm{H}_{\mathrm{o}} h}}=1,0503
$$

$$
\mathrm{B}_{2}=\frac{1}{1-\sum \mathrm{P}_{\mathrm{u}} / \sum \mathrm{P}_{\mathrm{e}}}=1,0453
$$

Portanto:

$$
M_{\text {máx }} \cong 7.854,737 \mathrm{kN} . \mathrm{cm}
$$

Os resultados obtidos pelos três procedimentos, que praticamente coincidem entre si, confirmam que os efeitos de segunda ordem majoraram os efeitos de primeira ordem em algo próximo a $5 \%$ do valor inicial. Embora dois únicos exemplos não costumem ser suficientes para extrapolar resultados, deve ser salientado que este também é o obtido em diversos trabalhos de diversos autores [ 9 ] [ 15 ] [ 19 ] [ 35 ] [ 39 ].

Apenas como complementação, pode-se tentar interpretar o procedimento da NBR-8800 como de incrementos sucessivos, ou seja, admitindo-se que em um nó qualquer possa ser escrito:

$$
\begin{aligned}
& H_{F}=H_{0}+\Delta H_{1}+\Delta H_{2}+\ldots+\Delta H_{n} \\
& \Delta_{F}=\Delta_{0}+\Delta_{1}+\Delta_{2}+\ldots+\Delta_{F}
\end{aligned}
$$

onde: $\quad H_{0}=$ valor nominal da ação horizontal

$$
\Delta H_{i}=\text { incrementos fictícios à ação } H_{0} \text {. }
$$

sendo: $\Delta H_{i}=\Delta_{i-1} \cdot \Sigma P / h$

$\Delta H_{1}=\Delta_{0} \quad \Sigma P / h$

$\Delta H_{2}=\Delta_{1} \Sigma P / h$

e assim prosseguindo sucessivamente. 
Como a estrutura é perfeitamente elástica-linear, pode-se escrever:

$$
\frac{\mathrm{H}_{\mathrm{F}}}{\Delta_{\mathrm{F}}}=\frac{\mathrm{H}_{\mathrm{o}}}{\Delta_{0}}=\frac{\Delta \mathrm{H}_{1}}{\Delta_{1}}=\frac{\Delta \mathrm{H}_{2}}{\Delta_{2}}=\ldots=\frac{\Delta \mathrm{H}_{\mathrm{h}}}{\Delta_{\mathrm{n}}}
$$

As relaçōes anteriores permitem retirar:

$$
\Delta_{\mathrm{i}}=\Delta \mathrm{H}_{\mathrm{i}} \cdot \frac{\Delta_{0}}{\mathrm{H}_{0}}
$$

que, particularizada para o primeiro incremento permite escrever a equação de $\Delta \mathrm{H}_{2}(3.5 .14 \mathrm{~b})$ da seguinte maneira:

$$
\Delta \mathrm{H}_{2}=\Delta_{1} \sum \mathrm{P} / \mathrm{h}=\frac{\Delta \mathrm{H}_{1} \Delta_{0}}{\mathrm{H}_{0}} \sum \mathrm{P} / \mathrm{h}
$$

Introduzindo a equação ( $3.5 .14 a$ ) chega-se a:

$$
\Delta \mathrm{H}_{2}=\frac{\Delta \mathrm{H}_{1}^{2}}{\mathrm{H}_{\mathrm{o}}}
$$

Pode-se utilizar o mesmo procedimento para a determinação de $\Delta H_{3}$ :

$$
\Delta \mathrm{H}_{3}=\Delta_{2} \sum \mathrm{P} / \mathrm{h}=\Delta \mathrm{H}_{2} \frac{\Delta_{0}}{\mathrm{H}_{\mathrm{o}}} \sum \mathrm{P} / \mathrm{h}=\Delta \mathrm{H}_{2} \frac{\Delta \mathrm{H}_{1}}{\mathrm{H}_{\mathrm{o}}}
$$

Introduzindo na expressão anterior, a expressão de $\Delta \mathrm{H}_{2}(3.5 .14 \mathrm{C})$ obtém-se:

$$
\Delta \mathrm{H}_{3}=\Delta \mathrm{H}_{1}\left(\frac{\Delta \mathrm{H}_{1}}{\mathrm{H}_{0}}\right)^{2}
$$

Continuando com o mesmo raciocínio, conclui-se que $\mathbf{H}_{\mathbf{F}}$ pode ser expresso pela série geométrica:

$$
\mathrm{H}_{\mathrm{F}}=\mathrm{H}_{\mathrm{O}}+\Delta \mathrm{H}_{1}+\Delta \mathrm{H}_{1}\left(\frac{\Delta \mathrm{H}_{1}}{\mathrm{H}_{\mathrm{O}}}\right)+\ldots+\Delta \mathrm{H}_{1}\left(\frac{\Delta \mathrm{H}_{1}}{\mathrm{H}_{\mathrm{O}}}\right)^{\mathrm{n}-1}
$$

Colocando $H_{0}$ em evidência na equação anterior: 


$$
H_{F}=H_{0}\left[1+\frac{D H_{1}}{H_{0}}+\left(\frac{D H_{1}}{H_{0}}\right)^{2}+\left(\frac{D H_{1}}{H_{0}}\right)^{3}+\ldots+\left(\frac{D H_{1}}{H_{0}}\right)^{n-1}\right]
$$

Desprezando os têrmos com expoente superior à unidade, uma vez que a relação $\Delta H_{1} / H_{0}$ é muito inferior a este valor, pode-se representar a série toda somente por:

$$
H_{T}=H_{0}\left(1+\frac{\Delta H_{1}}{H_{0}}\right)=\frac{H_{0}}{1-\frac{\Delta H_{1}}{H_{0}}}
$$

Introduzindo a equação ( $3.5 .14 \mathrm{a}$ ), onde $\Delta H_{1}=\Delta_{\mathrm{o}} \Sigma P / h$, na equação de $H_{F}$ ( 3.5 .17 ) retorna-se à expressão de $B_{2}$ ( 3.5.8) preconizada pelo AISC-LRFD, ou seja:

$$
H_{F}=\frac{H_{0}}{1-\sum P \frac{\Delta_{0}}{H_{0} h}}
$$

Portanto, não foi por acaso que os valores do exemplo anterior, calculados por normas diferentes quase coincidiram. Como procurou-se mostrar, os procedimentos de cálculo são os mesmos, apenas varia o número de têrmos das séries utilizadas em cada uma das resoluções.

\section{6- INFLUÊNCIA DAS LIGAÇÕES}

Como já escrito no capítulo inicial, o tipo de ligação infiuencia o custo de fabricação e de montagem de uma estrutura, bem como a rigidez, tanto a individual de cada elemento como a da estrutura com um todo.

Quanto à rigidez das ligações, o comportamento de cada uma permite classificá-las em rígidas, semi-rígidas e flexíveis.

Como rigidas são entendidas aquelas onde praticamente não ocorrem rotaçōes relativas entre os elementos conectados, como semirígidas as que restringem parcialmente este giro relativo e como flexiveis as que oferecem pequena resistência a este giro. 
As ligações totalmente flexiveis, ( rótulas perfeitas ), quase não são mais utilizadas. Foram muito empregadas nas estruturas do início do século, visando compatibilizar o modelo teórico e o real, contudo são de difícil e laboriosa execução, envolvendo um significativo volume de mão de obra e elevando, consequentemente, o custo final da construção.

Segundo o AISC [ $2 ; 3$ ] as ligações podem ser classificadas como flexíveis, ou do tipo 3 , quando absorvem até $20 \%$ do momento que passa pela ligação, como semi-rígidas, ou do tipo 2, as que absorvem entre 20 e $90 \%$ deste momento e como rigidas, ou do tipo 1 , as que absorvem $90 \%$ ou mais, deste mesmo momento.
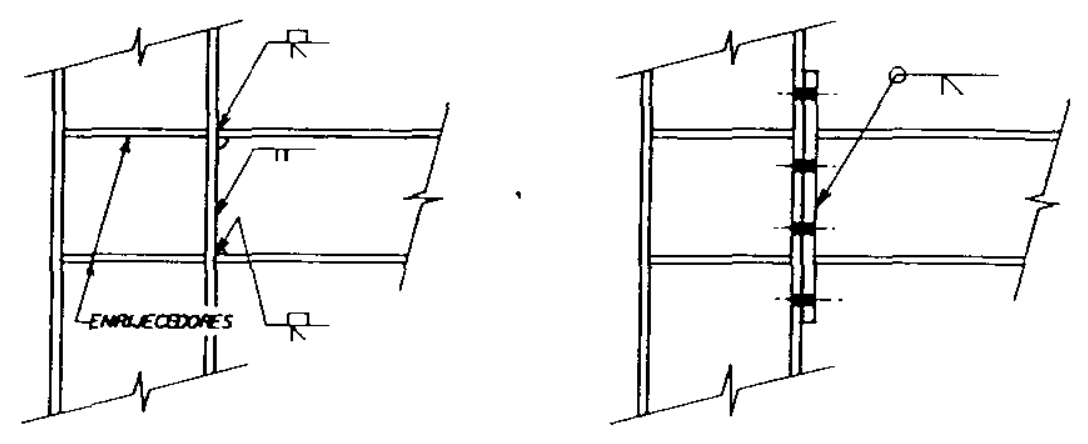

Figura 3.13 - Ligações Rigidas, ou do tipo 1 ( engastes )

Portanto, esta classificação é função da rigidez, que depende dos detalhes construtivos de cada ligação.

A NBR-8800 não classifica ou divide as ligações, apenas recomenda que estas devem ser dimensionadas com capacidade suficiente para que consigam transmitir a totalidade dos esforços existentes no nó, ficando assim definido, em função das solicitações, a rigidez das ligaçōes.
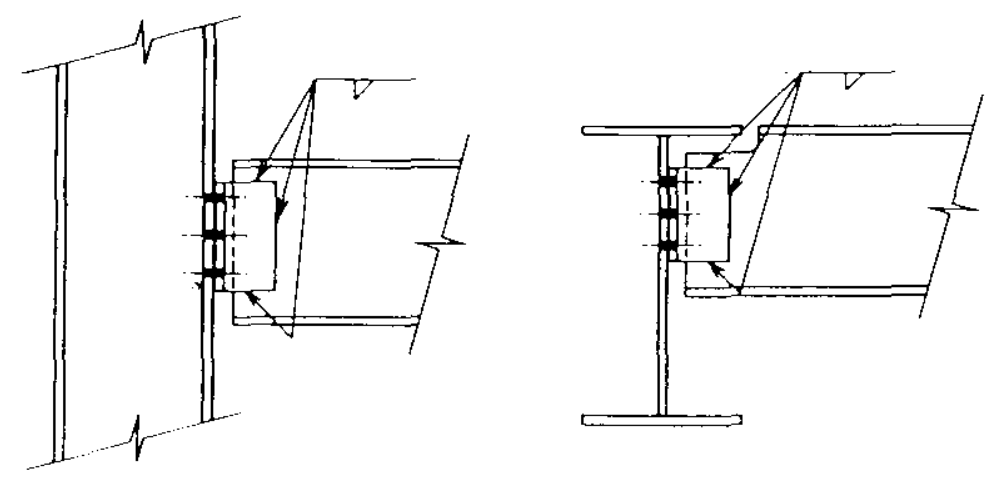

Figura 3.14 - Ligações Flexiveis, ou do tipo 3 (rótulas). 
No caso das ligações rígidas, as mais empregadas em têrmos de Brasil, são as soldadas e as com chapa de topo.

Entre as ligações consideradas flexiveis, mas que são semi-rígidas, as mais empregadas são as formadas por duas cantoneiras soldadas à alma da viga. Nestas ligações, conforme salienta PRELORENTZOU [ 22 ], ocorre uma determinada restrição ao giro, que depende, principalmente, da rigidez das cantoneiras e da viga.

As ligações do tipo 2, consideradas como semi-rígidas pelo AISC, não costumam ser empregadas entre nós, principalmente pelos custos de mão-de-obra envolvidos na sua execucão.
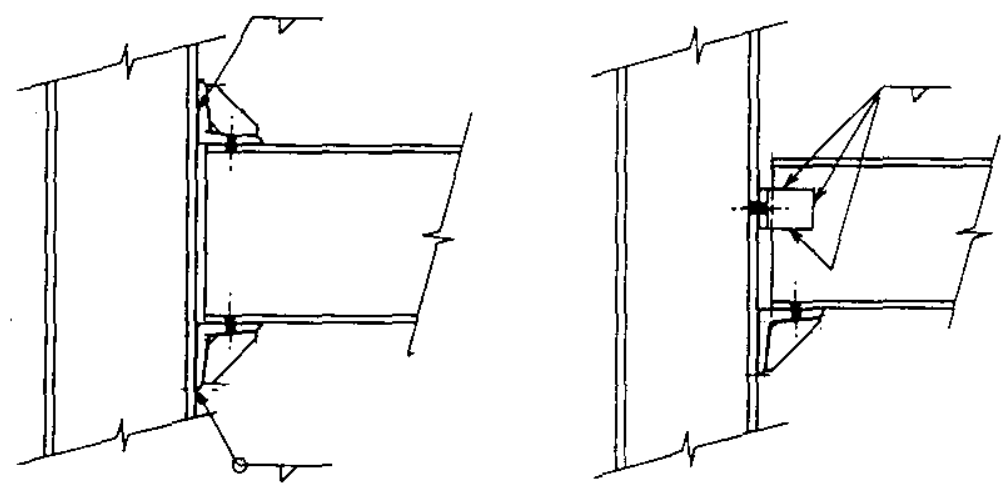

Figura 3.15 - Ligações Semi-Rígidas ou do tipo 2

A influência das ligações na elástica das vigas pode ser evidenciada na relação ( $M-\theta$ ), que costuma ser deduzida pelo desenvolvimento exposto a seguir, retirado de SALMON [ 35 ]:

$\mathrm{Na}$ viga da figura seguinte, os momentos nas extremidades podem ser escritos como:

$$
\begin{aligned}
& M_{\mathrm{a}}=M_{\mathrm{Fa}}+\frac{4 \mathrm{EI}}{\ell} \theta_{\mathrm{a}}+\frac{2 \mathrm{EI}}{\ell} \theta_{\mathrm{b}} \\
& M_{\mathrm{b}}=M_{\mathrm{Fb}}+\frac{2 \mathrm{EI}}{\ell} \theta_{\mathrm{a}}+\frac{4 \mathrm{EI}}{\ell} \theta_{\mathrm{b}}
\end{aligned}
$$

Colocando as equaçōes em função de $\theta$ :

$$
M_{a}-M_{F a}=\frac{2 E I}{\ell}\left(2 \theta_{a}+\theta_{b}\right)
$$




$$
M_{b}-M_{F b}=\frac{2 E I}{\ell}\left(\theta_{a}+2 \theta_{b}\right)
$$

Subtraindo a segunda da primeira, chega-se a:

$$
\begin{gathered}
\left(M_{a}-M_{F a}\right)-\left(M_{b}-M_{F b}\right)=\frac{2 E l}{\ell}\left(2 \theta_{a}+\theta_{b}-\theta_{a}-2 \theta_{b}\right) \\
\left(\theta_{a}-\theta_{b}\right) \frac{2 E l}{\ell}=\left(M_{a}-M_{F a}\right)-\left(M_{b}-M_{F b}\right)
\end{gathered}
$$

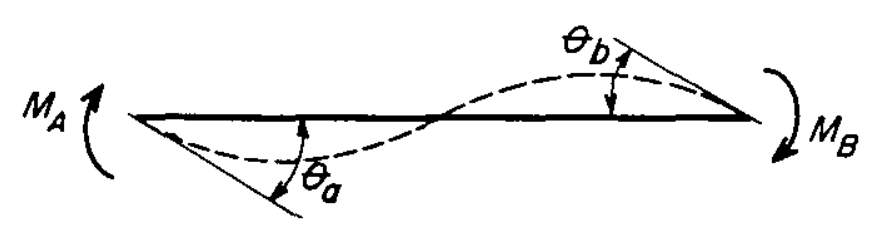

a) Momentos e Deslocamentos Finais

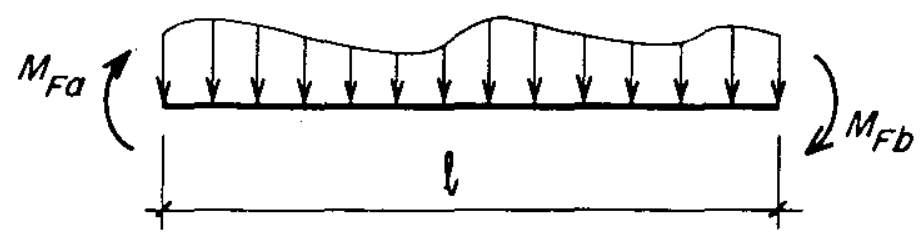

Figura 3.16 - Solução Clássica de Viga Bi-engastada

No caso de carregamento simétrico obtém-se: $M_{b}=-M_{a}$

$$
\begin{gathered}
\theta_{b}=-\theta_{a} \\
M_{F b}=-M_{F a}
\end{gathered}
$$

quando então: $\quad 2 \theta_{\mathrm{a}} \mathrm{El} / \ell=\mathrm{M}_{\mathrm{a}}-\mathrm{M}_{\mathrm{Fa}}$

ou escrevendo em função de $M_{a}$ :

$$
\mathrm{M}_{\mathrm{a}}=\dot{\mathrm{M}_{\mathrm{Fa}}}+\frac{2 \mathrm{EI}}{\ell} \theta_{\mathrm{a}}
$$

Para as ligações rígidas, quando então $\theta_{\mathrm{a}}=0$, resulta 


$$
M_{a}=M_{F a}
$$

Para as ligações flexiveis, que apresentam $M_{a}=0$, resulta:

$$
\theta_{\mathrm{a}}=-\mathrm{M}_{\mathrm{Fa}} /(2 \mathrm{El} / \ell)
$$

Colocando em gráfico estas duas situaçōes extremas, é possivel visualizar o comportamento típico das ligações.

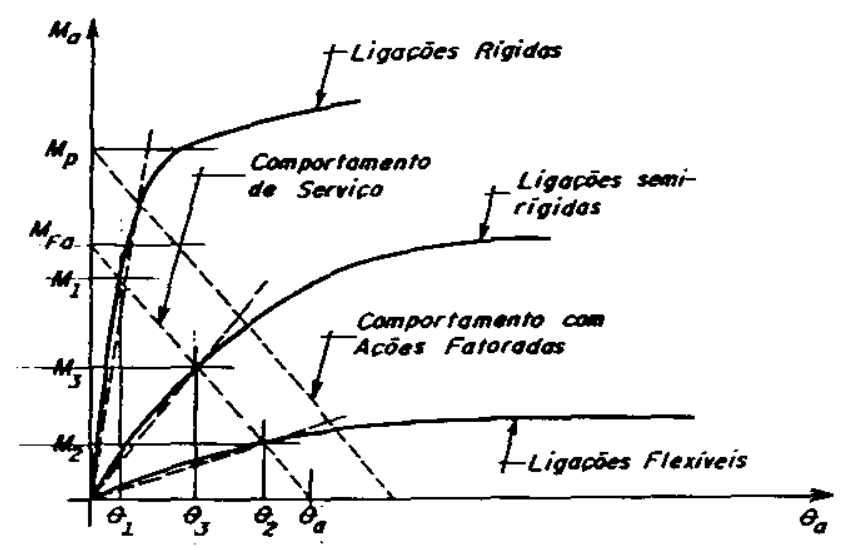

Figura 3.17 - Comportamento das Ligações ( LRFD )

Como é possivel perceber, não ocorre linearidade em nenhum trecho das curvas, que são traçadas baseadas em resultados experimentais, entretanto, é usual a adoção desta linearidade até as condições de serviço, uma vez que o êrro cometido não costuma ser muito grande. Para este trecho, a rigidez de uma ligação pode ser representada pela relação:

$$
K=M_{S} / \theta_{S}
$$

onde: $\mathbf{M}_{\mathbf{S}}=$ momento de serviço

$\theta_{S}=$ giro da ligação devido $a M_{S}$

Para as ligaçōès rígidas, a não linearidade observada nos resultados experimentais, pode ser atribuída à presença de tensões residuais, devidas às soldas necessárias a fabricação e às altas concentrações de tensões que ocorrem nas regiões dos furos, recortes e demais trabalhos de conformação. 
Nas ligações flexiveis, a não linearidade costuma ser explicada como causada pela plastificação dos extremos das cantoneiras, devido ao giro da extremidade da viga, que as obriga a girarem solidárias à mesma, ou então à plastificação que ocorre ao longo de toda a linha de conexão das abas, devido à deformação que é imposta às cantoneiras, para remover as forças deixadas para facilitar a montagem das vigas.

Dentre os diversos modelos já desenvolvidos para as ligações rígidas, tanto soldadas como parafusadas, como salienta PRELORENTZOU [ 32 ], o que melhor representa o comportamento destas ligações é o que considera o momento aplicado decomposto em um binário, formado por forças horizontais, aplicadas nas linhas de centro das mesas das vigas.
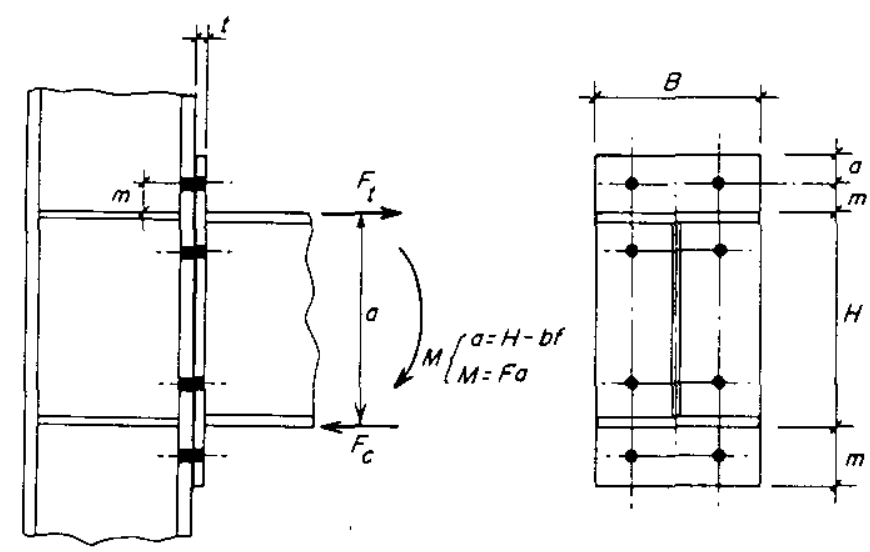

Figura 3.18 - Modelo Simplificado do Comportamento da Ligação.

O dimensionamento destas ligações pode ser feito, de modo a permitir a possivel formação de uma rótula plástica ou na ligação propriamente dita, ou então no corpo da viga.

No caso dos edifícios de andares mútiplos, a formação de rótulas plásticas só deve ocorrer para a combinação crítica das ações que incluir os efeitos horizontais devidos à ação do vento.

Como esta é uma ação extremamente variável no tempo, que pode inclusive alterar seu sentido de atuação, ou seja, uma rótula já formada pode ser "fechada", voltando o local a trabalhar com tensões mais baixas que as plastificantes', inclusive com inversão de sentido.

Neste caso é mais interessante que a rótula se forme na extremidade da viga, e não na ligação, pois introduziria deformações na chapa de topo que comprometeriam o desempenho da mesma, devido às deformações e desalinhamentos que poderiam ocorrer. 
Portanto, para que a rótula, caso se forme, localize-se na viga, deve a ligação ser suficientemente rígida, para forçar este comportamento.

Ainda segundo PRELORENTZOU [ 32 ], que afirma ser possivel e adequado, admitir que a rigidez da ligação seja proporcional à espessura da chapa, deve-se adotar, para esta espessura, o menor valor que não permita o surgimento do efeito alavanca ("Pryng Action"), portanto sem deformações aparentes.

Para que não ocorra o efeito de alavanca, o AISC-LRFD [ 2 ], limita a espessura da chapa pela expressão:

$$
t_{f} \geq \sqrt{\frac{4 F b^{\prime}}{\phi_{b} \omega f_{y}}}
$$

onde: $F=$ força de tração de parafuso

$b^{\prime}=b-(d / 2)$ sendo $d$ o diâmetro do parafuso

$\phi_{\mathrm{b}}=0,9$ (coeficiente de minoração da resistência)

$\omega=$ distância entre parafusos

$f_{y}=$ tensão de escoamento do aço da chapa de topo.

A equação anterior é obtida partindo-se do clássico desenvolvimento, apresentado a seguir, para posterior discussão:

$\mathrm{Na}$ figura seguinte, a aba superior da viga, que é tracionada por ação do momento, pode introduzir deformações na chapa de topo que dão origem às forças de equilíbrio $q$, distribuídas ao longo da borda superior e às forças $\mathbf{F}$, aplicadas a cada um dos parafusos, formada pela parcela devida à força $F_{T}$ à reação $q$.
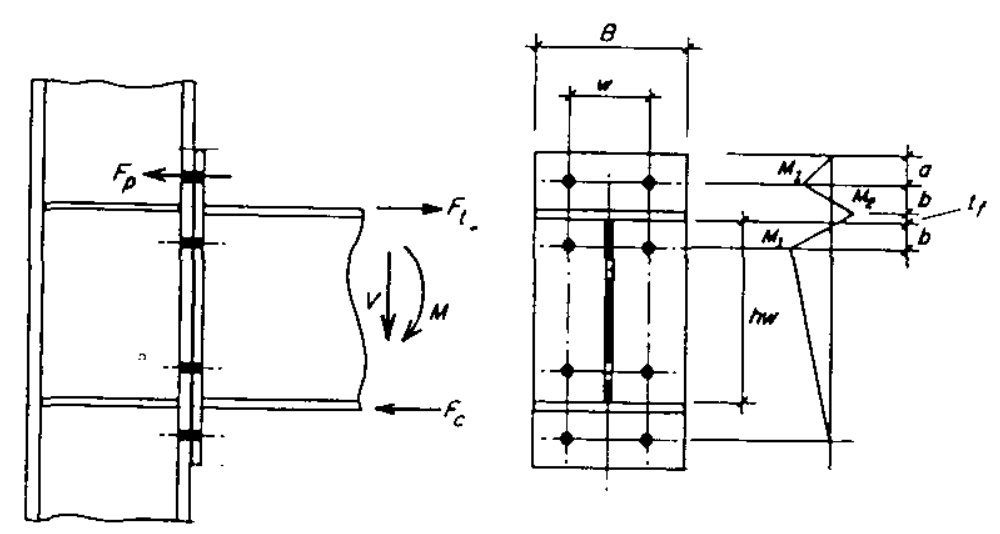

Figura 3.19 - Efeito de Alavanca em uma Ligação 
A deformaçāo da chapa e as forças despertadas na ligação, permitem determinar as seguintes relações:

$$
\begin{aligned}
& Q \cong q \cdot \omega \\
& F_{p} \cong\left(F_{t} / 4\right)+Q=F+Q \\
& M_{1}=Q \cdot a \\
& M_{2}=F_{p} \cdot b-Q(a+b)=F \cdot b-Q \cdot a
\end{aligned}
$$

Como $M_{2}$ atua na largura bruta $\boldsymbol{\omega}$ e $\mathbf{M}_{1}$ na largura líquida ( $\left.\omega-\mathrm{d}\right)$, costuma-se estabelecer a seguinte relação entre estas duas larguras:

$$
\delta=\frac{\omega-\mathrm{d}}{\omega}=1-\frac{\mathrm{d}}{\omega}<1,0
$$

que permite escrever $\boldsymbol{M}_{\mathbf{1}}$, em função de $\boldsymbol{M}_{\mathbf{2}}$ e de $\delta$, ou seja:

$$
M_{1}=\alpha \delta M_{2}
$$

sendo:

$$
\alpha=M_{1} / \delta M_{2}
$$

a relação entre $\mathbf{M}_{1}$ e $\mathbf{M}_{2}$, corrigida para a largura líquida da chapa.

Voltando à expressão de $\mathbf{M}_{\mathbf{2}}$ :

$$
M_{2}=F \cdot b-Q \cdot a=F \cdot b-M_{1}=F \cdot b-\alpha \delta M_{2}
$$

Portanto:

$$
M_{2}=\frac{F b}{1+\alpha \delta}
$$

O momento máximo que a chapa suporta pode ser expresso como:

$$
M_{p \ell}=\phi_{b} Z f_{y}=\phi_{b}\left(t^{2} / 4\right) \omega f_{y}
$$

Para que não ocorra um estado limite deve ser respeitada a desigualdade: 


$$
M_{\mathrm{p} \ell} \geq M_{2}
$$

Portanto:

$$
t \geq \sqrt{\frac{4 F b}{\phi_{b} \omega f_{y}(1+\alpha \delta)}}
$$

Para que não ocorra o efeito de alavanca, a reação $Q$ deve ser nula, quando então $M_{1}=0 \mathrm{e}$, consequente $\alpha=0$, resultando na expressão anterior de $\mathrm{t}$ :

$$
t \geq \sqrt{\frac{4 F b^{\prime}}{\phi_{b} \omega f_{y}}}
$$

que é a mesma equação anterior ( 3.6.5.), inclusive o têrmo $\mathbf{b}$, também substituido por $\left(\mathbf{b}^{\prime}=\mathbf{b}-\mathbf{d} / \mathbf{2}\right)$, apenas para aproximar os resultados teóricos dos experimentais .

Ocorrendo o efeito de alavanca, o valor de $\alpha$ será maior do que zero, porém não deve ultrapassar a unidade, que será então o outro valor extremo, indicando que $M_{1}=\delta M_{2}=M_{p \ell}$, ou seja, formar-se-ão rótulas plásticas na linha dos parafusos e na junção da chapa de topo com a mesa da viga. Nesta situação obtém-se o limite inferior para a espessura da chapa, pela equação:

$$
t \geq \sqrt{\frac{4 F b^{\prime}}{\phi_{b} \omega f_{y}(1+\delta)}}
$$

Entretanto, resultados experimentais, confirmam serem conservativos os valores obtidos para $\mathbf{t}$ nas equaçōes anteriores. Dos diversos modelos teóricos propostos, segundo PRELORENTZOU [ 32 ], o que conduz a uma espessura menor da chapa de topo, utiliza a equação:

$$
t \leq \sqrt{\frac{F_{t} b}{\phi_{b} f_{y} B}}
$$

Sendo este o valor superior. 
Para o limite inferior é indicada a seguinte equação:

$$
t \geq \sqrt{\frac{F_{t}}{\phi_{b} f_{y}\left(\frac{B}{b}+\frac{h_{w}}{\omega}\right)}}
$$

Admitindo, para efeito de comparação, que na figura anterior os valores geométricos sejam os seguintes: $B=25 \mathrm{~cm}$

$$
\begin{aligned}
& b=5 \mathrm{~cm} \\
& h_{w}=40 \mathrm{~cm} \\
& \omega=15 \mathrm{~cm} \\
& d_{p}=1,9 \mathrm{~cm} \\
& \delta=0,8733
\end{aligned}
$$

Obtém-se pelas equações do AISC-LRFD:

$$
0,7593 \sqrt{\frac{F}{\phi_{b} f_{y}}} \leq t \leq 1,0392 \sqrt{\frac{F}{\phi_{b} f_{y}}}
$$

e, pelas equaçōes propostas:

$$
0,7223 \sqrt{\frac{F}{\phi_{b} f_{y}}} \leq t \leq 0,8944 \sqrt{\frac{F}{\phi_{b} f_{y}}}
$$

Que confirmam serem conservadores os valores obtidos pelas expressões fornecidas pelo LRFD, recomendando-se portanto a adoção da equação de Mann \& Morris, proposta por Prelorentzou, para o limite superior, de modo a não ocorrer o efeito de alavanca, ainda assim propiciando uma redução de aproximadamente $16 \%$ na espessura da chapa de topo.

O valor constante do esforço $F$ para todos os parafusos, obtido pela divisão pura e simples da força de tração $F_{t}$ pelo número de parafusos, contidos nos dois lådos da mesa tracionada da viga, pode ser justificado pela maior rigidez da chapa de topo abaixo da mesa da viga, que pode ser considerada engastada em duas bordas, em relação à rigidez da mesma chapa acima da mesa, que possui engaste apenas em uma borda, com as demais livres. 
Esta maior rigidez, segundo Mann \& Morris [ 32 ], tende a igualar os valores das forças aplicadas a cada linha de parafusos. Como conclusão dos seus ensaios, Surtess e Mann [ 32 ] recomendam este procedimento, porém sugerem aumentar em $33 \%$ o valor de $F_{t}$, para assegurar ser este um razoável limite superior.

$\mathrm{Na}$ coluna, desde que sejam colocados enrijecedores de alma, pode ser admitido que as suas deformaçōes sejam suficientemente pequenas, quase não influenciando no giro relativo dos elementos conectados pois, como mostra FIELDING [ 17 ], o giro da conexão será a diferença entre o giro da viga e o da coluna, ou seja:

$$
\phi_{\text {con }}=\phi_{\mathrm{b}}-\phi_{\mathrm{c}}
$$

Para as conexões rígidas $(\mathrm{Fr})$ tem-se: $\phi_{\text {con }}=0$ portanto $\phi_{\mathrm{C}}=\phi_{\mathrm{b}}$.

A espessura da chapa de topo não deve ser superior à espessura da mesa da coluna, senão o efeito de alavanca pode se transferir para esta, inutilizando toda a análise já feita. Caso isto ocorra deve-se substituir a mesa da coluna neste trecho, ou adotar outro sistema de reforço.

No painel de alma ocorrem deformações por cisalhamento, que em presença da força de compressão, podem ocasionar um efeito de segunda ordem. Visando minorar, ou mesmo eliminar este efeito, o AISC-LRFD, na sua edição de 1993, na seção K 1.7 recomenda adotar como limites de resistência ao cortante:

$$
\begin{array}{ll}
\text { Para : } P_{u} \leq 0,4 \mathrm{Py} & R_{v}=0,6 \text { Fy dc tw } \\
\text { Para : } P_{u}>0,4 P_{y} & R_{v}=0,6 \text { Fy dc tw }\left(1,4-P_{u} / P y\right)
\end{array}
$$

Com estes procedimentos previne-se o surgimento do efeito alavanca e de deformações significativas, devido ao cortante no painel da alma da coluna, às deformações da mesa da mesma coluna e às deformaçōes da chapa de topo, podendo a ligação ser considerada como indeformável até o valor de $\mathbf{V}_{\mathbf{p l}}$ da viga.

Quanto à atuação dos parafusos, vale lembrar que para os de alta resistencia, pré-tensionadas, o acréscimo de força externa à ligação só se transmite integralmente ao parafuso, após vencer a força de protensão que, por questōes de normalização, deve ser maior que o esforço aplicado, o que garante que os parafusos não afrouxem. 
Estes cuidados asseguram que a ligação só apresentará deformaçōes elásticas, e a formação de rótula plástica será transferida para a viga.

Para as ligações flexiveis, também foram desenvolvidos diversos modelos teóricos e seus resultados comparados a resultados experimentais, como o proposto por SALMON [ 35 ] ou o de PRELORENTZOU [ 32 ].

Entretanto, estes modelos determinam a rigidez, ou o giro das cantoneiras, sem contudo levar em conta a rigidez da viga. Por este motivo considera-se mais aplicável o modelo descrito a seguir:

A ligação representada na figura seguinte, compōe-se de duas cantoneiras soldadas à alma da viga. Caso esta ligação fosse uma rótula perfeita, o giro que aí ocorreria poderia ser expresso pela equação (3.6.3b), já deduzida :

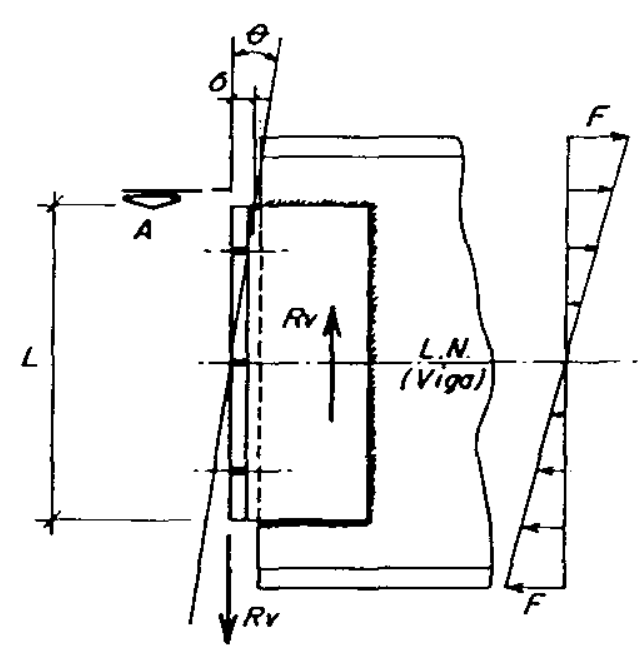

a) VISTA LATERAL

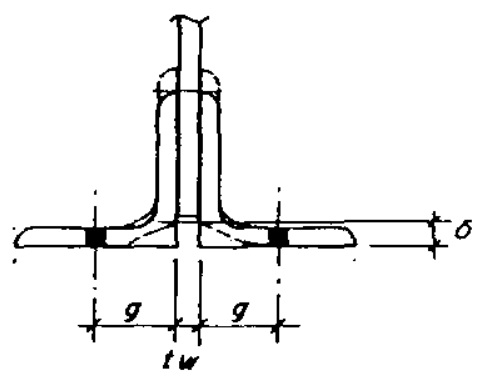

b) VISTA A

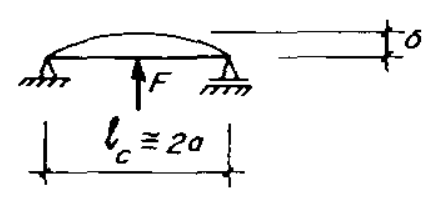

c) ESOUEMA ESTÁTICO

Figura 3.20 - Giro em Ligação Flexível

Para este giro, que pode ser considerado ocorrendo em relação à linha neutra da viga, que costuma ser também a $L N$ das cantoneiras, 0 deslocamento máximo $\delta_{\mathbf{a}}$ pode ser admitido como sendo igual a:

$$
\delta_{\mathrm{a}}=\theta_{\mathrm{a}} L / 2
$$

Entretanto, a resistência oferecida pelas cantoneiras a este giro, mesmo que pequena, introduz uma restrição nas duas extremidades que, existindo simetria estática e geométrica pode ser escrita como: 


$$
\theta_{1}=\frac{\mathrm{M} \ell}{2 \mathrm{EI}}
$$

onde: $M=$ momento introduzido nas extremidades da viga pela parcial restrição do giro.

$\ell=$ vão da viga

$E \mathrm{I}=$ rigidez da viga à flexão

Portanto, o giro final da extremidade da viga, na posição de equilíbrio, pode ser escrito como:

$$
\theta=\theta_{a}-\theta_{1}
$$

O deslocamento $\delta$, considerando o esquena estático simplificado apresentado na figura anterior, pode ser determinado fazendo-se:

$$
\delta=\mathrm{F} \ell_{\mathrm{c}}^{3} / 48 \mathrm{EI}_{\mathrm{c}}
$$

com: $\ell_{\mathrm{c}} \cong 2 \mathrm{~g}$

$\mathrm{El}_{\mathrm{C}}=\mathrm{Et}^{3} / 12\left(1-\mathrm{u}^{2}\right) \quad$ (Por unidade de comprimento)

$F=$ força despertada por unidade de comprimento das cantoneiras.

Tem-se: $\quad \delta=\frac{8 \mathrm{Fg}^{3} 12\left(1-\mathrm{u}^{2}\right)}{48 \mathrm{Et}}=1,82 \mathrm{Fg}^{3} / \mathrm{Et}^{3}$

e, consequentemente: $\theta \cong \delta / \frac{\mathrm{L}}{2}=3,64 \mathrm{Fg}^{3} / \mathrm{LEt}^{3}$

Por equilíbrio, o momento $M$ que a restrição ao giro $\theta_{1}$ introduz na extremidade da viga, deve ser igual, em módulo, ao momento despertado nas cantoneiras pelo giro imposto $\theta$, que pode ser determinado pelo diagrama de forças $\mathbf{F}$ apresentado na figura anterior, ou seja:

$$
M=F L^{2} / 6
$$

Deste modo, substituindo na equação do giro:

$$
\theta=\theta_{\mathrm{a}}-\theta_{1}=3,64 \mathrm{Fg}^{3} / \mathrm{LEt}^{3}=\theta_{\mathrm{a}}-\frac{\mathrm{FL}^{2} \ell}{12 \mathrm{El}}
$$


obtém-se uma expressão para calcular o valor máximo da força F, ou seja :

$$
F=\frac{\theta_{a} E}{\left[\frac{3,64 g^{3}}{L t^{3}}+\frac{L^{2} \ell}{12 !}\right]}
$$

Conhecido o valor de $\mathbf{F}$, podem ser determinados os demais parâmetros, ou então, caso só se deseje a rigidez da ligação, basta fazer :

$$
K=M / \theta=\frac{E L^{3} t^{3}}{21,84 g^{3}}
$$

que independe totalmente do valor de $\mathbf{F}$.

Aplicando estas equações a uma viga simplesmente apoiada, submetida a uma ação uniformemente distribuída de $30 \mathrm{kN} / \mathrm{m}$, com 8 metros de vão e inércia de $42.556 \mathrm{~cm}^{4}$ (VS $550 \times 64$ ), encontra-se:

$$
\theta_{\mathrm{a}}=\frac{\mathrm{p} \ell^{2}}{12} /(2 \mathrm{E} / / \ell)=\frac{\mathrm{p} \ell^{3}}{24 \mathrm{El}}=0,0073 \mathrm{rad}
$$

Admitindo que na ligação foram utilizadas 2 cantoneiras de $64 \times 64 \times 6 \times 300$, com g = 35mm, obtém-se:

$$
K=151.350 \mathrm{kN} . \mathrm{cm} / \mathrm{rad}
$$

e, consequentemente: $\quad \mathrm{F}=6,89 \mathrm{kN}$

$$
\begin{aligned}
& \theta=0,0068 \mathrm{rad} \\
& \theta=0,0005 \mathrm{rad} \quad \text { e. portanto: } \theta_{1} / \theta_{\mathrm{a}}=6,85 \% \\
& \delta=0,10 \mathrm{~cm}
\end{aligned}
$$

Caso as cantoneiras utilizadas fossem de $76 \times 76 \times 8$, com g $=44 \mathrm{~mm}$ e $\mathrm{t}=7,95 \mathrm{~mm}$ os resultados quase que não se alteram, ou seja:

$$
\begin{aligned}
& \mathrm{K}=149.490 \mathrm{kN} \cdot \mathrm{cm} / \mathrm{rad} \\
& \mathrm{F}=6,81 \mathrm{kN} \\
& \theta=0,0068 \mathrm{rad} \\
& \theta_{1}=0,0005 \quad \text { e portanto: } \theta_{1} / \theta_{\mathrm{a}}=6,85 \%
\end{aligned}
$$

confirmando assim a grande flexibilidade deste tipo de ligação. 
Caso a viga utilizada fosse um perfil com maior altura, por exemplo, um VS $1000 \times 140$, com I $=305.593 \mathrm{~cm}^{4}$, porém para um vão de 12 metros e uma ação de $200 \mathrm{kN} / \mathrm{m}$ com distribuição uniforme, neste caso as cantoneiras de ligação devem ser de $102 \times 102 \times 9,53$, com $\mathrm{L}=825 \mathrm{~mm}$ e $\mathrm{g}=64 \mathrm{~mm}$, obtendo-se os seguintes resultados: $\theta_{\mathrm{a}}=0,023 \mathrm{rad}$

$$
\begin{aligned}
& \mathrm{K}=1.740 .210 \mathrm{kN} \cdot \mathrm{cm} / \mathrm{rad} \\
& \mathrm{F}=30,24 \mathrm{kN} \\
& \theta=0,0197 \mathrm{rad} \\
& \theta_{1}=0,0033 \mathrm{rad} \quad \theta_{1} / \theta_{\mathrm{a}}=14,28 \%
\end{aligned}
$$

e o momento na extremidade da viga devido à restrição ao giro será:

$$
M=\frac{2 E I \theta_{1}}{\ell}=34.456 \mathrm{kN} \mathrm{cm}
$$

como o momento de engastamento perfeito nos apoios é:

$$
M_{E P}=p \ell^{2} / 12=240.000 \mathrm{kN} . \mathrm{cm}
$$

A razão entre os dois momentos será:

$$
M / M_{E P}=14,36 \%
$$

No caso da viga de menor altura (VS 550x64) os valores seriam:

$$
\begin{aligned}
& M=1090 \mathrm{kN} . \mathrm{cm} \\
& M_{E P}=16.000 \mathrm{kN} . \mathrm{cm} \\
& M / M_{E P}=6,82 \%
\end{aligned}
$$

Cabe agora observar que os valores de momento despertados nos apoios, que são considerados como rótulas, não são significativos a ponto de comprometer os elementos assim dimensionados.

Entretanto, estas parcelas absorvidas nos apoios são subtraídas do momento que ocorre.no meio do vão, representando, em última análise, um ganho de resistência no caso das vigas apenas sob flexão, e de resistência e estabilidade no caso das vigas-colunas, onde ocorre flexo-compressão, devido à alteração do modo de flambagem como também pela redução no valor "exato" do fator $\mathbf{C}_{\boldsymbol{m}}$. 
Mais uma vez, por ser difícil quantificar com suficiente precisão a rigidez destas ligaçōes, costuma-se não considerá-la, o que representa, felizmente, um comportamento a favor da segurança, portanto conservador.

Nas ligações flexíveis, para estruturas de aço, a determinação da rigidez pode não introduzir diferenças significativas no comportamento global da estrutura como no comportamento individual de cada elemento estrutural. Porém, nas estruturas mistas aço-concreto, estas diferenças podem ser significativas.

No caso específico dos edifícios de andares múltiplos, as lajes dos pisos sempre darão origem a um comportamento misto, não sendo possivel fugir do problema, uma vez que agora o aumento da rigidez do nó pode ser significativa.

Deste modo, levando em conta a rigidez das conexōes, as expressões para os momentos finais nos extremos de uma viga, segundo Leon [ 26 ], tornam-se:

$$
\begin{aligned}
& M_{a}=\frac{2 E l}{\ell} \frac{1}{1+3 \alpha}\left[\left(\frac{2+3 \alpha}{1+\alpha}\right) \theta_{a}+\left(\frac{1}{1+\alpha}\right) \theta_{b}-3 R\right]+\frac{M_{F a}}{1+\alpha} \\
& M_{b}=\frac{2 E l}{\ell} \frac{1}{1+3 \alpha}\left[\left(\frac{2+3 \alpha}{1+\alpha}\right) \theta_{b}+\left(\frac{1}{1+\alpha}\right) \theta_{a}-3 R\right]+\frac{M_{F b}}{1+\alpha}
\end{aligned}
$$

onde: $\alpha=\frac{2 \mathrm{El}}{\ell \mathrm{k}_{\text {con }}}$

$\mathrm{R}=\Delta / \ell \quad(\Delta=$ deslocamento horizontal relativo entre os apoios $)$

$M_{a} ; M_{b} ; M_{F a} ; M_{F b} ; \theta_{a} ; \theta_{b}$ : possuem o mesmo significado anterior

$\mathrm{K}_{\text {con }}=\mathrm{K}_{\mathrm{a}}=\mathrm{K}_{\mathrm{b}}=$ rigidez das ligações.

As equaçōes anteriores são, a menos dos têrmos $\alpha$ e $R$, obtidas a partir das equações já apresentadas para a viga sob apoios flexíveis. Para comprovar esta afirmaçāo basta fazer $K_{\text {con }}$ tender a infinito, quando então $\alpha$ e $\mathbf{R}$ tendem a zero, e as equações tornam-se:

$$
\begin{aligned}
& M_{a}=\frac{2 E l}{\ell}\left(2 \theta_{a}+\theta_{b}\right)+M_{F a} \\
& M_{a}=\frac{2 E l}{\ell}\left(2 \theta_{b}+\theta_{a}\right)+M_{F_{b}}
\end{aligned}
$$

como pode ser observado na figura anterior. 
Voltando às equações de momento nas extremidades de vigas com ligações flexíveis e fazendo $\mathbf{K}$ variar de zero a infinito, obtém-se valores para estes momentos que podem ser colocados em gráficos como o da figura seguinte.

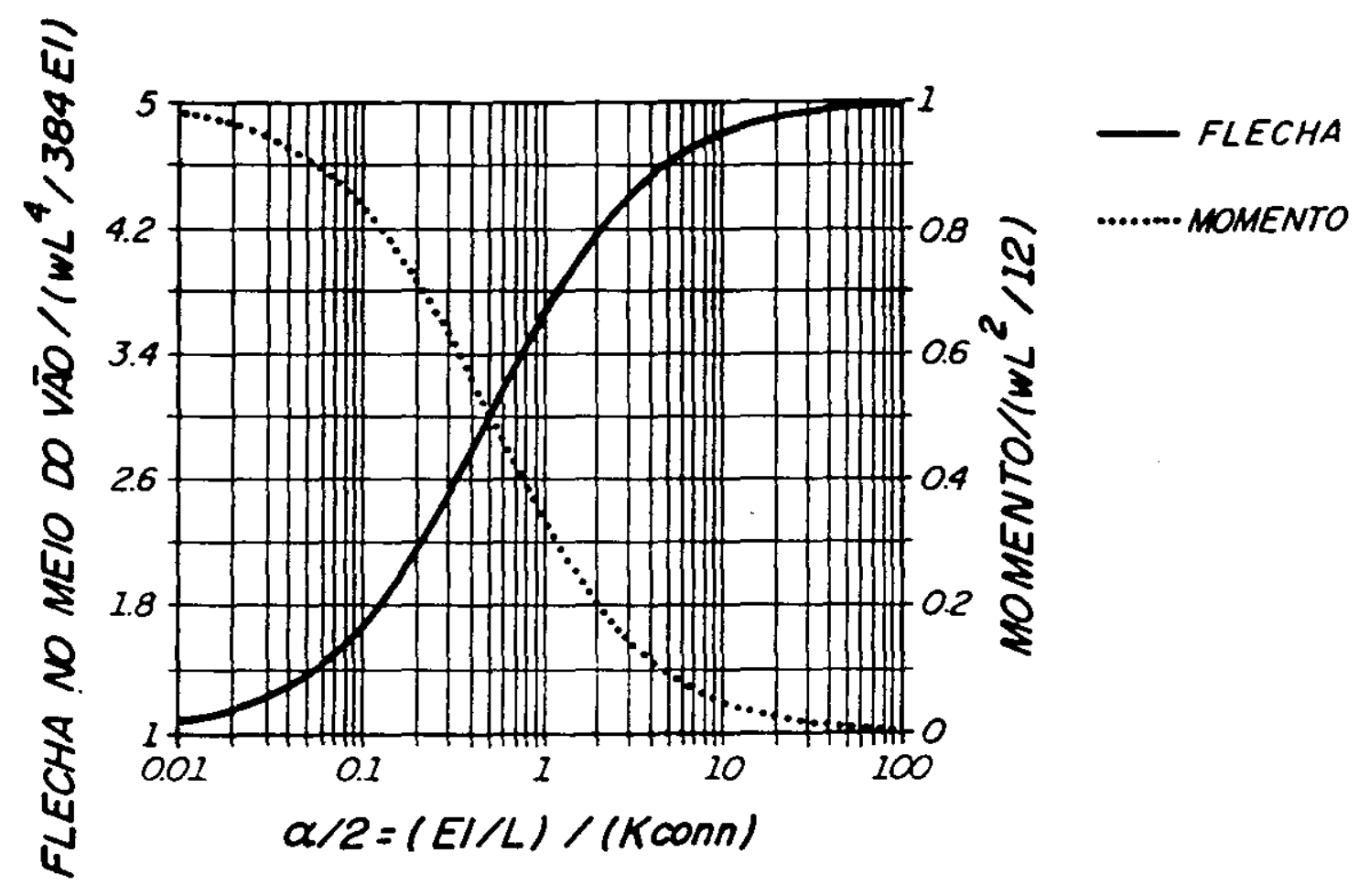

Figura 3.21 - Gráfico de Rigidez / Deslocamento

No gráfico, no eixo horizontal estão localizados valores de $\alpha / 2$, em escala logarítmica, que na origem representam a rigidez de uma ligação flexível e no extremo direito, a de uma ligação rígida. No eixo vertical, na borda esquerda estão os valores das flechas divididos por $\mathrm{p} \ell^{2 / 384 E I}$ e na borda direita os valores dos momentos de extremidade divididos pela constante $\mathrm{p} \ell^{2 / 12}$.

As curvas mostram o comportamento dos deslocamentos e os momentos de extremidade, em função da variação da rigidez das conexões.

Assim, para uma ligação rígida, com capacidade para absorver até $90 \%$ do momento de engastamento perfeito, obtém-se no gráfico $\alpha / 2=0,05$, ou seja, $\mathrm{K}_{\mathrm{con}}=\mathrm{El} / 0,05 \ell$. Do mesmo modo, para uma ligação que absorva apenas $10 \%$ do momento de engastamento perfeito, encontra-se $\alpha / 2=4,5$ e $\mathrm{K}=\mathrm{El} / 4,5 \ell$. 
Do mesmo modo, para uma ligação flexivel, que absorva apenas $10 \%$ do momento de engastamento perfeito, encontra-se $\alpha / 2=4,5$ e a rigidez relativa desta ligação que é de $\mathrm{K}=\mathrm{El} / 4,5 \mathrm{l}$.

Nas vigas anteriormente analisadas, os valores encontrados para a rigidez das conexões, que foram de $151.350 \mathrm{kN} / \mathrm{rad}$ para o VS 550x64 e de $1.700 .210 \mathrm{kN} / \mathrm{rad}$ para o VS $1000 \times 140$, permitem entrar no gráfico e retirar as parcelas absorvidas de momento nas ligações, que ficam em torno de $6 \%$ para a viga menor e de $15 \%$ para a viga maior.

Estes valores estão coerentes com os encontrados utilizando o procedimento proposto, que foram de $6,8 \%$ e $14,4 \%$, respectivamente.

Uma vez que o modelo proposto apresentou resultados satisfatórios para um perfil simples, ou seja, uma viga isolada, pode-se adaptá-lo para uma viga mista, onde o concreto da laje, por ter continuidade além da coluna, restringe o giro da viga no plano da mesa superior, que está solidarizada com a laje.

Neste caso duas situações distintas podem ocorrer, dependendo do sentido do momento aplicado, se positivo ou negativo.

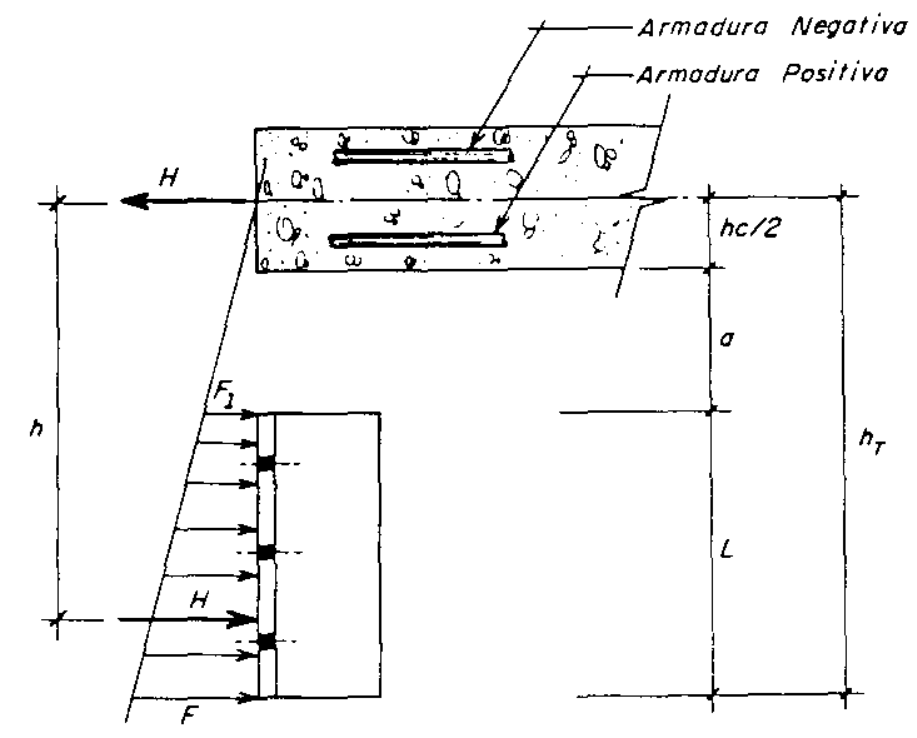

Figura 3.22 - Ligação de Viga Mista

No caso de ócorrer momento positivo na ligação, o concreto que compōe a laje de piso será comprimido, não exigindo maiores cuidados, uma vez que as tensōes introduzidas não devem ser altas. As tensões de tração serão transmitidas pelas cantoneiras, podendo ocorrer o escoamento na parte mais afastada da linha neutra. 
Porém para momentos negativos, quando então o concreto será tracionado, alguns cuidados devem ser tomados, uma vez que esta tração, deverá ser absorvida pela armadura da laje, que usualmente pode pode ser assumida como dupla, com a resultante passando muito próxima do meio da espessura da laje. As tensões de tração serão transmitidas às cantoneiras, que podem apresentar plastificações nos mesmos pontos já citados.

Desta forma, em estado de serviço, ou em regime elástico, as forças despertadas na ligação podem ser representadas como na figura anterior, que por equilíbrio permite escrever:

$$
\begin{aligned}
& H=\frac{L}{2}\left(F+F_{1}\right) \\
& M=H h
\end{aligned}
$$

e, por semelhança de triângulos:

$$
\frac{F}{h_{T}}=\frac{F_{1}}{h_{T}-L}
$$

Portanto,

$$
F_{1}=F \frac{h_{T}-L}{h_{T}}
$$

e a força $\mathbf{H}$ pode ser escrita só em função de $\mathbf{F}$, resultando:

$$
H=\frac{F L}{2}\left(1+\frac{h_{T}-L}{h_{T}}\right)
$$

Escrevendo $h_{\mathrm{T}}=\mathbf{k} \mathbf{L}$, a expressão anterior torna-se:

$$
H=\frac{F L}{2}\left(1+\frac{k-1}{k}\right)=\frac{F L}{2 k}(2 k-1)
$$

Introduzindo a expressão anterior ( 3.6.30a ) na de momento (3.6.27):

$$
M=H h=h \frac{F L}{2 k}(2 k-1)
$$

O momento também pode ser expresso em função de $F$ e $F_{1}$, ou seja 


$$
M=F_{1} L\left(h_{T}-\frac{L}{2}\right)+\left(\frac{F-F_{1}}{2}\right) L\left(h_{T}-\frac{L}{3}\right)
$$

que, introduzindo $\boldsymbol{k}$ e a expressão de relação entre $\mathbf{F}$ e $\boldsymbol{F}_{1}(3.6 .29)$, tornase:

$$
M=F^{2}\left[k+\frac{1}{3 k}-1\right]
$$

igualando ( 3.6 .31$)$ e ( 3.6 .33 ) as duas expressões para o momento, encontra-se:

$$
h=\left[\frac{6 k(k-1)+2}{3(2 k-1)}\right]
$$

Conhecendo $\mathbf{h}$, pode-se, por analogia com o procedimento anterior, fazer:

$$
\theta=\theta_{\mathrm{a}}-\theta_{1}
$$

sendo: $\theta_{\mathrm{a}}=\mathrm{M}_{\mathrm{Fa}} /(2 \mathrm{El} / \ell$

$$
\begin{aligned}
\theta & \cong \delta / h_{\mathrm{T}}=\delta / \mathrm{kL}=1,82 \mathrm{~F} \mathrm{~g}^{3} / \mathrm{E} \mathrm{t}^{3} \mathrm{~kL} \\
\theta_{1} & =\mathrm{M} \ell / 2 \mathrm{El}=\mathrm{Hh} \ell / 2 \mathrm{El}
\end{aligned}
$$

que introduzindo as expressões deduzidas para $\mathbf{H}$ e $\mathbf{h}$ (3.6.30a) e (3.6.34), na expressão para $\theta_{1}$ encontra-se :

$$
\theta_{\uparrow}=\frac{\mathrm{FL}^{2} \ell}{2 \mathrm{EI}}\left[(\mathrm{k}-1)+\frac{1}{3 \mathrm{k}}\right]
$$

Para obter a expressão que permite determinar $O$ valor de $F$, substitui-se os valores dos giros, ou seja:

$$
\theta_{\mathrm{a}}=\theta+\theta_{1}=\frac{1,82 \mathrm{Fg}^{3}}{\mathrm{Et}^{3} \mathrm{~kL}}+\frac{\mathrm{FL}^{2} \ell}{2 \mathrm{El}}\left[(\mathrm{k}-1)+\frac{1}{3 \mathrm{k}}\right]
$$

que, resolvida em têrmos de $F$ fornece:

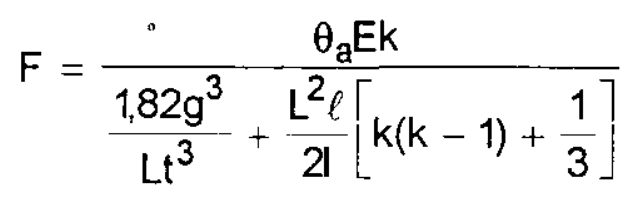

e, a rigidez da ligação será: 


$$
K=M / \theta=\frac{E L^{3} t^{3}}{5,46 g^{3}}[3 k(k-1)+1]
$$

Fazendo $k=1$, que significa admitir o comprimento da ligação igual ao comprimento das cantoneiras, $\left(h_{T}=L\right)$ obtém-se:

$$
K=\frac{E L^{3} t^{3}}{5,46 g^{3}}=4 \frac{E L^{3} t^{3}}{21,84 g^{3}}
$$

que é quatro vezes maior que o valor encontrado para a viga não mista, 0 que confirma ser interessante levar esta rigidez em consideração.

As expressões anteriores podem ser usadas em situações onde ocorre momento positivo, bastando corrigir o valor do coeficiente $k=h_{T} / L$

Aplicando estas equações nas vigas já examinadas, admitindo que suas propriedades geométricas são as de uma seção mista, somente para efeito de comparação, encontra-se para $k=1,5 \mathrm{~L}$ :

a) Viga VS $550 \times 64$

$$
\begin{aligned}
& \theta_{1}=0,0035 \mathrm{rad} \\
& H=232,34 \mathrm{kN} \\
& M=7551 \mathrm{kN} . \mathrm{cm}
\end{aligned}
$$

$$
\mathrm{F}=11,617 \mathrm{kN}
$$$$
\theta=0,0038 \mathrm{rad}
$$$$
\mathrm{h}=32,5 \mathrm{~cm}
$$

$\mathrm{K}_{\text {con }}=1.967 .548 \mathrm{kN} . \mathrm{cm} / \mathrm{rad}$

Utilizando as expressões propostas por LEON [ 26 ] obtém-se para o valor do momento nos apoios:

$$
M_{\mathrm{a}}=7551 \mathrm{kN} . \mathrm{cm} \quad(\operatorname{com} \alpha=1,1085)
$$

que confere com o resultado obtido anteriormente.

b) Para a viga VS $1000 \times 140$

$$
\begin{aligned}
& \mathrm{F}=33,426 \mathrm{kN} \\
& \theta=0,0073 \mathrm{rad} \\
& \mathrm{h}=89,37 \mathrm{~cm} \\
& \mathrm{~K}_{\text {con }}=22.508 .176 \mathrm{kN} . \mathrm{cm} / \mathrm{rad}
\end{aligned}
$$$$
\theta_{1}=0,0157 \mathrm{rad}
$$$$
\mathrm{H}=1.848,43 \mathrm{kN}
$$$$
\mathrm{M}=164.310 \mathrm{kN} . \mathrm{cm}
$$

E, pelo procedimento proposto por LEON [ 26 ]:

$$
M_{\mathrm{a}}=164.047 \mathrm{kN} \cdot \mathrm{cm} \quad(\operatorname{com} \alpha=0,4639)
$$

que também quase coincide com o resultado anterior. 
Vale agora observar que as relações entre o momento final nos apoios e o momento de engastamento perfeito, serão:

$$
\begin{aligned}
& \text { (VS 550×64): } M / M_{E P}=47,19 \% \\
& \text { (VS 1000x100): } M / M_{E P}=68,46 \%
\end{aligned}
$$

o que confirma a grande rigidez destas ligações, que costumam ser tratadas como flexiveis, ou seja, como rótulas.

Entretanto, não e usual que estas ligações possuam tamanha rigidez, apesar da presença da laje de concreto, com toda a sua massa. Como o modelo desenvolvido exige, para sua exatidão, o comportamento elásticolinear dos materiais constituintes da ligação, pode-se determinar as tensões de serviço, para verificar como estes materiais estão se comportando.

No caso da laje de concreto, para a viga de maior altura, que possui o maior valor de $\mathbf{H}$, é possível admitir uma área colaborante definida como:

$$
A_{c}=h_{c} b_{c} \quad \text { onde: } h_{c}=15 \mathrm{~cm} \quad b_{c}=16 \times 15=240 \mathrm{~cm}
$$

Portanto:

$$
A_{c}=3600 \mathrm{~cm}^{2}
$$

Com $\mathrm{H}=232,34 \mathrm{kN}$ encontra-se: $\sigma_{\mathrm{c}}=64,5 \mathrm{~N} / \mathrm{cm}^{2}\left(6,5 \mathrm{kgf} / \mathrm{cm}^{2}\right)$ que não costuma tirar o sono dos calculistas de concreto armado.

Caso este esforço seja de tração e deva ser absorvido pela armadura encontra-se, utilizando a taxa mínima da NBR 6118.

$$
\sigma_{\mathrm{t}}=21,51 \mathrm{kN} / \mathrm{cm}^{2}
$$

que já é um valor mais significativo, mas que pode ser resolvido com o aumento da taxa ou com a consideração da armadura dupla existente nestes pontos.

O problema realmente se concentra nas cantoneiras, onde 0 aparente fluxo de tensões não autoriza a adoção do comportamento de viga na análise das tensões, pois os resultados obtidos em simulaçōes numéricas não se aproximam dos obtidos com o procedimento manual.

Porém, os dois procedimentos indicam o mesmo ponto, como sob as maiores tensões, conforme esquematizado na figura seguinte, situadas entre 18 e $26 \mathrm{kN} / \mathrm{cm}^{2}$. 
Vale a observação de que os deslocamentos máximos no ponto ficaram em torno de $1 \mathrm{~mm}$, o que positivamente não garante a mobilização da rigidez total da ligação, por estar dentro das folgas passiveis de serem encontradas em uma junta real.

Salienta-se no entanto, que no dimensionamento da ligação deve ser levado em conta a rigidez teórica da mesma, para a determinação das espessura das soldas e do diâmetro dos parafusos

Para a análise da viga pode ser considerada um valor entre 0,3 a 0,5 desta rigidez, ficando a critério do projetista a consideração ou não na análise global da estrutura.

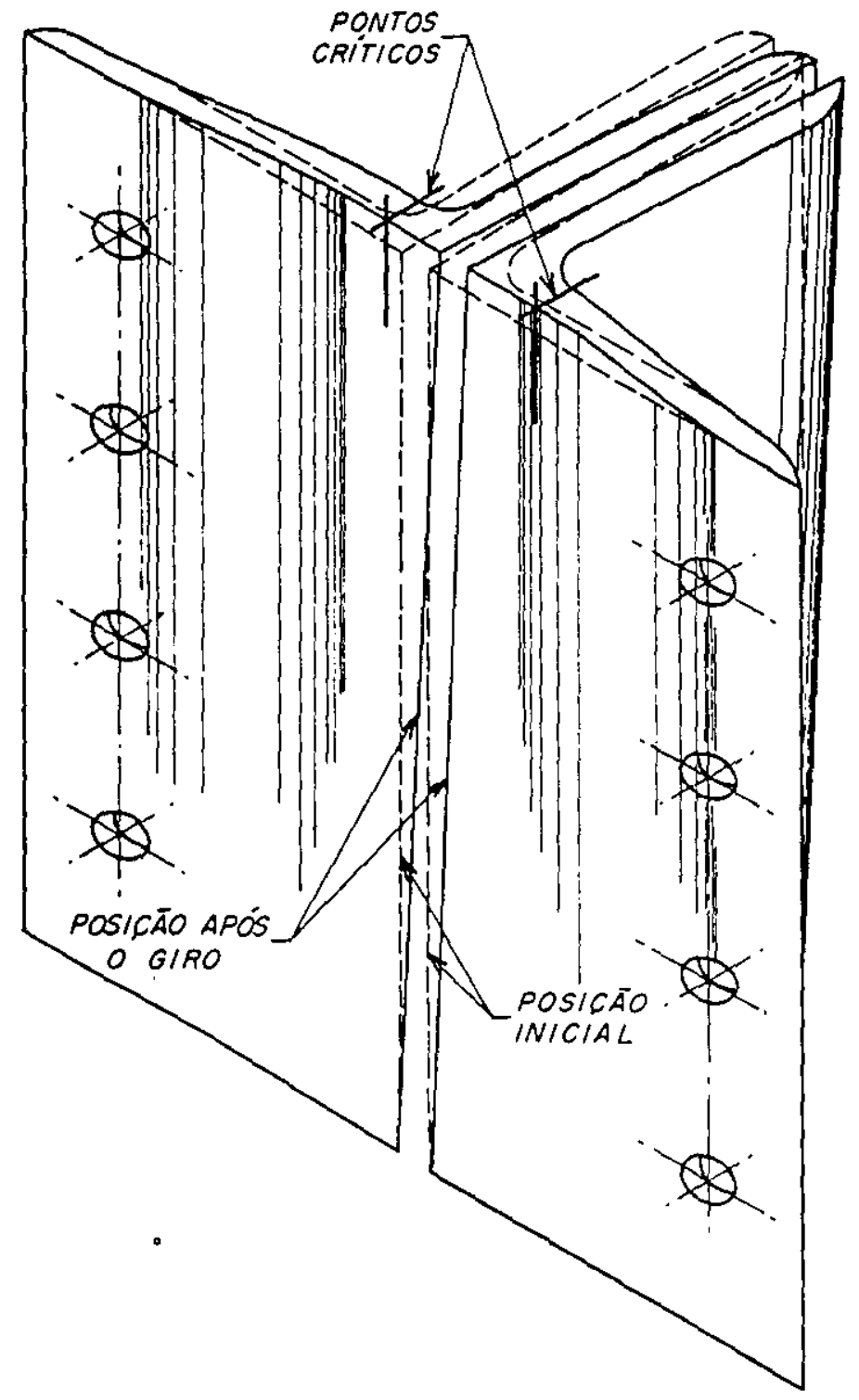

Figura 3.23 - Concentração de Tensões nas Cantoneiras de Ligação. 


\section{7 - COMBINAÇÕES DE AÇÕES}

Quanto às combinações de ações, as normas atuais também são conflitantes, ou pelo menos apresentam recomendações diferentes.

A NBR-8800 contempla dois estados limites a serem verificados, que são os estados limites últimos e os de utilização. Para os estados limites últimos devem ser verificadas as combinações normais, que são as que podem ocorrer ao longo da vida útil da estrutura e as combinações que podem surgir durante as operações de montagem. Para os estados limlites de utilização são válidas as mesmas combinações, porém com coeficientes de majoração das açōes diferentes.

A determinação dos coeficientes de majoração das ações é função, portanto, da combinação em análise, sendo seus valores apresentados no corpo da referida norma. Porém, o valor a ser utilizado no fator de combinação $\psi_{0}$, pode conduzir a interpretações incorretas, pois consta que - mesmo deve ser tomado como igual a unidade, para todas as ações variáveis decorrentes do uso da edificação. Ficando a critério do projetista a decisão sobre quais ações serão decorrentes do uso ou não.

Exemplificando, as combinações normais possiveis em um edificio que possui três ações a serem combinadas, a de peso próprio $\left(P_{p}\right)$, a devida à sobrecarga ou carga útil do prédio $\left(\mathrm{S}_{\mathrm{c}}\right)$ e a devido ao vento $(\mathrm{W})$ podem ser escritas, já assumindo valores para os coeficientes, como:

$$
\begin{aligned}
& C_{1}=1,3 P_{p}+1,5 S_{c}+1,4 \times 0,6 W \\
& C_{2}=1,3 P_{p}+1,4 W+1,5 S_{c}
\end{aligned}
$$

Parece ser evidente que a combinação 2 deverá ser a crítica, a menos que se aplique o fator de redução na sobrecarga, que deixará então de ser decorrente do uso da edificação.

No caso da ação do vento possuir sentido favorável, que é o sentido contrário às ações de peso próprio, bastaria analisar apenas uma combinação, que seria:

$$
C_{3}=1,0 P_{p}-1,4 W
$$

uma vez que nesta combinação a ação de sobrecarga não deve ser incluida, pois a mesma seria somada à ação de peso próprio. 
No mesmo edifício, caso fosse aplicada a especificação do AISCLRFD, a combinação crítica, que mais se parece com a da NBR 8800 , para o sentido desfavorável será:

$$
C_{4}=1,2 P_{p}+1,3 W+0,5 S_{c}
$$

Ficando evidente as diferenças existentes entre os coeficientes das duas normas. Caso a comparação fosse feita com outras normas, o resultado não seria muito diferente. Infelizmente não há justificativas para 0 fato da nossa norma ser conservadora em relaçāo às demais normas.

Entretanto, para manter a análise ao campo de abrangência da NBR 8800 , devem ser tecidos mais alguns comentários sobre as combinações de ações que estão diretamente ligadas ao projeto dos edifícios.

A busca da combinação crítica, no caso específico destas construções, pode ficar restrita às combinaçōes já apresentadas, que consistem na soma de todas as ações de mesmo sentido e na soma do peso próprio com as açōes que eventualmente possam aliviar esta incidência, tanto para as combinações normais como para as de construção.

A análise em segunda ordem, que a NBR 8800 não define se é uma verificaçāo nos estados limites últimos ou de utilização, é esclarecida pela norma NBR 8621, que a considera dos estados limites últimos e fornece parâmetros para a distribuição do coeficiente de majoraçāo, que deve agora ser aplicado parte nas ações e parte nas solicitações.

Para os estados limites de utilização a norma não fixa valores para os deslocamentos devidos ao peso próprio, ficando subentendido que os mesmos devem ser cobertos pelas deformações de fabricação. Parece ficar também evidente que, para o espírito da norma, apenas os deslocamentos provocados pelas açōes variáveis é que devem ser limitados.

Para a verificação do comportamento dinâmico, mais uma vez por não estar claro se esta é uma verificação nos estados limites últimos ou de utilização, podem surgir dúvidas sobre qual tipo de análise deve ser feita. Esta indefinição, nem a NBR 8621 esclarece, porém, como será mostrado no item correspondente, esta é uma análise que visa verificar o conforto dos usuários da estrutura e não, comio muitos possam achar, a estabilidade ou a resistência da mesma.

Portanto esta é uma verificação de serviço, ou nos estados limites de utilização. 


\section{4- SISTEMAS APORTICADOS}

\section{1-ORIGEM DOS SISTEMAS}

Como procurou-se mostrar, as estruturas formadas por barras, induziram ao longo dos séculos o aperfeiçoamento dos sistemas estruturais, de uma forma intuitiva no início e, ao final, apoiado em teorias e experimentaçōes técnicas.

As construções de menor porte, como as tendas nômades ou aquelas construídas essencialmente em madeira, precisavam, como ainda precisam, de um sistema que the permitissem resistir às forças advindas da incidencia do vento. Nas tendas empregavam-se cordas inclinadas que, mediante sua resistência à tração, impediam que o vento as arrastasse, e barras rígidas que, mediante sua resistência tanto à tração como à compressão, garantiam esta mesma estabilização às construções de madeira.

Até os dias atuais estas construções utilizam estes sistemas de estabilização, desenvolvidas nos primórdios das civilizações.

Nas construções em alvenaria, tal solicitação não chegava a constituir um obstáculo, devido principalmente ao elevado peso próprio destas construções, que as manteve como única solução viável para construções mais altas até o advento do ferro fundido.

Buscando um sistema estrutural que viabilizasse o emprego, inicialmente do ferro fundido e posteriormentne do seu sucessor, o ferro forjado, os construtores lançaram mão dos ensinamentos já obtidos com a madeira, uma vez que estes materiais são empregados quase que exclusivamente na forma de barras.

Para estes casos, a melhor solução estrutural resultou em dois sistemas básicos: pilares em ferro e paredes em alvenaria, ou então pilares e vigas em ferro, com diagonais, também em ferro, formando treliças verticais, racionalmente dispostas. 
Foram estes os sistemas empregados nos prédios do início da revolução industrial.

Com o advento do aço e do concreto armado, estes mesmos sistemas continuaram a ser empregados, porém incorporando as melhorias técnicas que estes materiais apresentavam em relação aos então utilizados, como maior resistência, possibilitando construções mais altas e com maiores vãos e a característica do monolitismo que praticamente eliminou o uso de contraventamentos.

Com o progressivo aumento da altura das edificaçōes, visando melhorar o desempenho destas frente às ações horizontais, mais uma vez 0 monolitismo do concreto armado permitiu a execução de pilares tão largos que são melhor analisados quando assemelhados a paredes.

Este mesmo monolitismo permitiu que os pilares-parede que contornam os elevadores, caixas de escadas e chaminés de serviço, dessem formação a outro elemento estrutural, agora em forma de tubo.

Nos edifícios em aço, estes mesmos elementos estruturais só puderam ser criados a partir do treliçamento entre os pilares que envolvem estes mesmos locais, com as conseqüentes dificuldades na execução dos fechamentos ou mesmo de prejuizos estéticos.

Com a evolução da cultura tecnológica foi possivel conceber edificios com as treliças aparentes nas fachadas e como resposta a esta tendência, os projetistas em concreto armado visualizaram a possibilidade de concentrar o maior número possivel de pilares junto às fachadas, deixando - interior quase que livre, buscando com esta disposiçăo um comportamento estrutural próximo do comportamento estrutural de um tubo perfeito.

Como ápice desta busca pelo sistema estrutural ideal, busca-se ultimamente, a construção de estruturas totalmente mistas aço-concreto, tanto nos pisos como nos pilares ou mesmo nos núcleos de serviço.

Basicamente são estas as opçōes usuais para enrijecer uma estrutura, mas que costumam dar origem a uma imensa série de combinaçōes, cujo limite depende das tecnologias existentes ou dos aportes financeiros disponiveis.

Deste modo, não é possivel encontrar uma unanimidade entre os diversos autores sobre as denominações dos sistemas estruturais já executados. 
Neste trabalho, pareceu ser interessante reduzi-los a apenas quatro grupos, sendo cada grupo possuidor de uma caracteristica estrutural importante que o diferencia dos demais, não se atendo às condições secundárias.

Portanto, os quatro grupos principais a serem analisados são:

\author{
a - Sistemas Aporticados \\ b - Sistemas com Núcleo Resistente \\ c - Sistemas Treliçados \\ d-Sistemas Tubulares
}

Entretanto, antes de analisar os sistemas estruturais propriamente dito, cabem algumas considerações a respeito da estrutura dos pisos, pois os edifícios de andares múltiplos devem ser entendidos, na sua forma mais simplificada, como formados por uma série de planos horizontais, constituídos por vigas e lajes, que são os pisos dos andares, e por uma série de planos verticais que contém os pilares, as paredes resistentes e os núcleos estruturais.

Aos pisos cabe absorver as ações verticais e distribuí-las entre os pilares ou outros elementos resistentes. Fazem portanto parte do sistema resistente, merecendo por isso um pouco de atenção.

\title{
4.2- SISTEMAS DE PISOS
}

Nos edificios de andares múltiplos os pisos possuem uma outra função, além da inicialmente prevista, que é trabalharem como diafragmas, distribuindo os esforços horizontais entre os elementos resistentes, quer sejam pilares, núcleos, treliças verticais, pórticos, etc.

Por esta razãó, devem possuir uma rigidez suficiente para realizar esta distribuição. Quando executados em laje de concreto, fundido no local, possuem uma rigidez mais do que suficiente.

Quando executados em elementos pré-moldados, nem sempre tal rigidez é alcançada, exigindo alguns cuidados adicionais. 
Nesta situação, utilizando elementos pré-fabricados, pode-se projetar um contraventamento ao nivel das vigas, de modo a conseguir a rigidez necessária, ou então procurar formar com as vigas de aço e o concreto de capeamento uma estrutura mista.

A execução da segunda opção, muito mais prática e econômica do que a primeira, exige apenas que na região das vigas seja deixado um espaço que permita ao concreto de capeamento entrar em contato com a viga, ligando-se por meio de conectores, de qualquer tipo, como pino com cabeça, perfis laminados ou em chapa dobrada, barras redondas, etc.

A espessura do concreto de capeamento deve ser suficiente para poder distribuir as solicitações horizontais do andar.

Outra vantagem que o sistema misto apresenta, é a possibilidade de considerar as vigas contidas lateralmente ao longo do seu comprimento, eliminando assim o estado limite de flambagem lateral com torção, uma vez curado o concreto.

Nos edifícios destinados a fins residenciais, as lajes não possuem grandes dimensões e a experiência tem mostrado que a execução de lajes com formas de madeira ou mesmo metálicas, conduz a bons resultados. Entretanto, nos edifícios destinados a fins comerciais, quando então pode ser mais interessante deixar o espaço totalmente livre, sem paredes fixas, exceto nas áreas destinadas aos serviços, as lajes podem ter dimensões muito maiores e para tornar o processo de escoramento mais econômico, ou mesmo inexistente, podem ser utilizadas formas metálicas, que devido às suas características de dobramento e conformação tornam-se parte da estrutura.

Uma vez determinado o tipo de piso a ser utilizado, bem como a sua execução, é possível determinar a distância, ou afastamento das vigas que irão sustentá-lo.

Nos edifícios residenciais, costumam-se fazer coincidir, sempre que possivel, as vigas e as paredes. Nos edifícios comerciais, como já escrito, quando planeja-se deixar o espaço livre, a disposição das vigas assume uma grande importância, que varia de acordo com o sistema estrutural adotado para resistir às açōes horizontais.

Das vigas utilizadas no piso, costuma-se chamar de principais, àquelas que também fazem parte do enrijecimento vertical do edifício, e de secundárias às que se destinam apenas a suportar as ações verticais, provenientes do piso. 
Portanto, as vigas principais são conduzidas, pela características das açōes que as solicitam, a esforços bastante diferentes das secundárias. Enquanto estas últimas podem ser assumidas como biapoiadas, as primeiras quase sempre devem ter uma ou as duas extremidades engastadas.

Embora costuma-se dizer que uma situação estrutural será mais rígida ou mais econômica quanto mais alto for o seu grau de estaticidade, no caso das vigas de um piso, quando passiveis de serem executadas como mistas, a solução biapoiada, portanto isostática, costuma conduzir a uma solução mais interessante que uma situação biengastada.

A explicação para este fato reside no comportamento da mesa inferior. Na situação biapoiada esta mesa é continuamente tracionada, enquanto a mesa superior é continuamente comprimida, porém travada lateralmente pela laje do piso, o que the garante a estabilidade lateral. Nas vigas hiperestáticas, devido à inversão do momento fletor, a mesa que não estiver contida lateralmente poderá, ao ficar sob compressão, perder a sua estabilidade lateral.

Para assegurar esta estabilidade costuma-se aumentar a inércia neste plano, consumindo-se mais material sem um ganho significativo na resistência à flexão no plano do carregamento.

Este aparente paradoxo estático, de que uma estrutura isostática é mais econômica que uma outra mais hiperestática, é comprovado na prática, onde os pisos mais leves e mais econômicos são os que possuem mais vigas isostáticas. Esta economia é tão significativa, que diversos projetistas procuram utilizar outros elementos para resistir às ações horizontais, deixando a totalidade das vigas do piso como secundárias.

Estabelecido este princípio básico na concepção de um piso, pode-se passar a análise do segundo fator que mais influencia o consumo de aço, que é a disposiçāo das vigas, influenciada pelos vãos, espaçamento e tipo de seção das vigas, mas que também depende do sistema de enrijecimento vertical da construção.

Nas vigas com seção "l", o vão, assim como o espaçamento econômico entre as m̉esmas, pode atingir até 18 metros [ 28 ].

Entretanto, o valor extremo só é viável economicamente, quando são empregadas formas de aço incorporadas, ou vigas secundárias que reduzem as dimensões das lajes, quer maciças, nervuradas ou prémoldadas. 
No caso dos edificios comerciais, deve ser levado em conta a necessidade de prever um espaço conveniente para a passagem de dutos, destinados a serviços como ar condicionado, instalaçōes elétricas, telefonia, comunicações, etc.

Para minimizar a distância entre os pisos, estes dutos devem correr no mesmo plano das vigas principais, interceptando-as algumas vezes, quando então podem conduzir a algumas soluções, como por exemplo:

\section{a - Aberturas nas almas \\ b - Treliças de altura constante \\ c - Camadas sobrepostas de perfis}

As aberturas nas almas das vigas podem ser especificas ou gerais. Como específicas devem ser entendidas aquelas projetadas em acordo com os projetistas dos serviços, ou então quando já existe o projeto específico, com a trajetória e as dimensões das tubulações perfeitamente definidas.

Esta, entretanto, não é a seqüência utilizada no desenvolvimento do projeto global de uma construção de grandes dimensões, uma vez que quase nunca existe uma coordenação entre as várias especialidades envolvidas e mesmo existindo, não poderá assegurar que alteraçōes que passam ocorrer em trajetórias, ou a inclusão de novos dutos, não exigirá aberturas em almas de vigas já fabricadas ou mesmo montadas.

Por este motivo, é sempre aconselhável utilizar vigas com diversas aberturas, além das necessárias, que permitam a qualquer tempo 0 remanejamento ou a passagem de novos dutos.

Vale lembrar que em qualquer dos casos os locais das aberturas devem ser verificados e, no caso das aberturas especificas, quase sempre reforçados, visando evitar o colapso da alma.

Levando ao extremo a eliminação da alma, foram empregadas em diversas construçōes, vigas treliçadas, que permitem uma flexibilidade total na disposição dos dutos.

Por último, a opção de sobrepor duas camadas de perfis, sendo os de uma camada ortogonais aos da outra, que permite também uma ótima flexibilidade nos dutos de serviço. Os perfis da camada superior podem formar uma estrutura mista com a laje, uma vez que estão em contato. As vigas inferiores podem ter também uma ligação com a laje, providenciada por porções de perfis em trechos racionalmente escolhidos, visando 
aumentar a rigidez do piso sem inviabilizar as possiveis variações do percurso dos dutos.

Uma viga, assim formada, terá um comportamento estrutural muito parecido com o de uma viga "viereendel".

Uma vez definido o sistema das vigas do piso, para iniciar a disposição das mesmas, podem ser adotados, como iniciais, vãos de 9 a 12 metros para as vigas principais e de 6 a 9 metros para as secundárias, evitando assim grandes espessuras para as lajes.

Quanto ao dimensionamento das vigas mistas, embora os primeiros estudos datem do início do século, somente em 1986 a norma NB-14, ao ser revisada, incluiu este assunto. As construções pioneiras dos anos 50 foram dimensionadas segundo critérios de normas estrangeiras, as alemã (DIN 1078) ou a americana, que consta do manual do AISC.

Os primeiros ensaios sobre vigas mistas, segundo MALITE [ 28 ], foram desenvolvidos pela empresa inglesa Redpath Brown and Company, ainda no ano de 1914. Estes ensaios precederam a teoria das lajes suportadas por vigas metálicas, formulada por Caughey e Scott, em 1925, que sugeriram inclusive a necessidade de colocar algum elemento entre a viga e a laje para transmitir os esforços de cisalhamento, e estudaram também as diferenças de comportamento entre as vigas escoradas e as não escoradas durante a cura do concreto.

Entre 1922 e 1940 foram construidos diversos edifícios e diversas pontes, como os citados no capítulo inicial deste trabalho, que já empregavam este sistema construtivos nos pisos e tabuleiros. Entretanto, somente em 1944 é que o sistema foi introduzido nas normas da AASHO "American Association of State Officials", e em 1951 no manual do AISC.

Após os anos 50, muito pouco foi acrescentado ao que já era conhecido. Os ensaios e estudos realizados ultimamente, contemplam mais o aspecto de variaçōes dos materiais, como a viga de alma cheia que foi substituida por treliça, às diversas variações na composição dos concretos estruturais e principalmente no tipo dos conectores.

Com a necessidade de proteger as estruturas contra a ação do fogo, foram desenvolvidos estudos de perfis totalmente envolvidos por concreto, que deram origem a outro tipo de viga mista, que inclusive propicia a dissimulaçāo da presença de perfis de aço nas estruturas dos edifícios. Este tipo de viga também está incluído nas verificações da versão atual NBR-8800 
Os perfis em chapas conformadas a frio, conhecidos entre nós como perfis de chapa dobrada, também foram utilizados em vigas mistas, que ainda não possuem normalização.

Como trabalho pioneiro, que serve como referência para aplicações em pequenas construçōes, pode ser citado o realizado por MALITE [ 28 ], que estudou este comportamento misto, visando exatamente este tipo de aplicação.

As conclusões dos ensaios realizados por Malite, confirmam e quantificam o que na prática diversos projetistas já tinham observado: que as vigas mistas formadas por perfis de chapa dobrada, possuem o mesmo comportamento daquelas com perfis laminados ou em chapas soldadas, desde que não surjam instabilidades locais nas partes comprimidas da seção.

Neste trabalho são também fornecidos valores da resistência para conectores em chapa dobrada, que não constam das normais usuais.

Outro aspecto do dimensionamento das vigas mistas, que não possue o consenso das diversas normas, ocorre nas regiões de momento negativo.

Algumas normas recomendam não considerar a interação nestas regiões, que então devem ter como único elemento resistente o perfil de aço. Outras normas apresentam procedimentos alternativos, que admitem a armadura da laje absorvendo parte deste momento.

Entretanto, a dificuldade consiste em determinar com qual momento de inércia serão calculadas as solicitações e se estas são constantes ao longo da viga.

A NBR-8800, no item 6.1.2, recomenda a aplicação de incrementos sucessivos de carregamento, com as propriedades geométricas da seção, para cada trecho específico do diagrama de momento fletor.

Assim, nas regiōes de momento positivo, onde ocorre a interaçāo aço/concreto, o momento de inércia a ser considerado é o da seção mista homogeneizada.

Nas regiōes de momento negativo, onde não ocorre a iteração, o momento de inércia é apenas o da viga metálica.

Devido à hiperestaticidade do problema, o diagrama final será obtido por quantas iteraçōes forem necessárias, para que os comprimentos dos trechos admitidos como de momentos positivos e negativos, repitam-se a menos de uma diferença considerada irrisória, na solução do problema. 
Para a aplicação dos incrementos de carregamento, utilizam-se os valores do diagrama inicial no primeiro incremento e do imediatamente anterior nos demais.

Este pode ser um procedimento éstaticamente correto, mas bastante trabalhoso, sem contudo poder ser indicado como exato, devido às incertezas existentes na própria essência do sistema, que é o comportamento estrutural de uma viga de aço ligada a uma laje de concreto.

Para agilizar a solução do problema, o manual do AISC, introduziu um procedimento alternativo, aplicável apenas na análise elástica, que permite a determinação dos esforços na viga, considerando uma inércia constante ao longo deste mesmo vão, igual à inércia da seção homogeneizada.

$\mathrm{Na}$ análise das seçōes com momento negativo, este procedimento permite considerar a contribuição da armadura longitudinal da laje, contida na largura efetiva, desde que esta armadura esteja devidamente ancorada.

Assim como a norma americana, a canadense, a inglesa, e outras normas européias apresentam procedimentos alternativos, que não serāo aqui comentados por não serem mais práticos ou mais exatos que o do AISC.

Quanto ao aspecto de escorar ou não a viga de aço durante a cura do concreto, deve ser levado em conta o possível transtorno que o escoramento pode introduzir no cronograma, embora possa conduzir a um dimensionamento mais econômico.

Sobre a redução no volume ou no pêso do material utilizado nos pisos, como as espessuras das lajes ou dos revestimentos, pode ser comentado que esta redução deve ser limitada pela possibilidade do mesmo, sendo muito leve, poder apresentar vibrações que causem desconforto dos usuários.

Tal como as vibraçōes introduzidas pela ação do vento, estas sāo funções da força externa mas, também da flexibilidade e do amortecimento da estrutura do piso.

Como já mostràdo em item anterior, a freqüência fundamental de uma viga pode ser determinada pela expressão:

$$
f=\frac{\omega}{2 \pi}
$$


onde: $\quad \omega=\frac{E \mathrm{El} \int_{0}^{\ell}\left(x^{\prime \prime}\right)^{2} \mathrm{dz}}{\mathrm{m} \int_{0}^{\ell} x^{2} \mathrm{dz}}$

admitindo que a viga seja biapoiada e que as ações aplicadas possuam distribuição uniforme ao longo do vão, pode-se escrever:

$$
\begin{aligned}
& \text { EI } x^{\prime \prime}=\frac{p}{2}\left(\ell z-z^{2}\right) \\
& \text { EI } x=\frac{p}{12}\left(\ell z^{3}-\frac{z^{4}}{2}-\frac{\ell^{3} z}{2}\right)
\end{aligned}
$$

substituindo na expressão de $\omega$, as duas expressões anteriores, após eleválas ao quadrado e integrá-las ao longo do vão da viga, encontra-se:

$$
\omega=9,8767 \sqrt{\mathrm{gEl} / \mathrm{p} \ell^{4}}
$$

donde: $\quad f=1,57 \sqrt{g E I / p \ell^{4}}$

No caso de uma viga biapoiada sob carregamento uniforme, o deslocamento máximo é determinado como sendo:

$$
\delta=5 \mathrm{p} \ell^{4} / 384 \mathrm{EI}
$$

isolando da expressão da flecha o fator da carga pelo vão:

$$
\mathrm{p} \ell^{4}=384 \mathrm{E} \mid \delta / 5
$$

que introduzida na expressão da freqüência natural ( 4.2 .5 ), conduz a:

$$
f=5,61 / \sqrt{\delta}
$$

que é a mais simples das expressões para a determinação da freqüência natural de uma viga biapoiada.

Nas vigas onde as ligações são semi-rígidas, LEON [ 26 ] fornece um fator de correção do valor da freqüência natural dado como:

$$
f_{n}=K_{n} \cdot f
$$


e os valores de $K_{n}$ podem ser obtidos do gráfico seguinte, em função do parâmetro $\alpha / 2$.

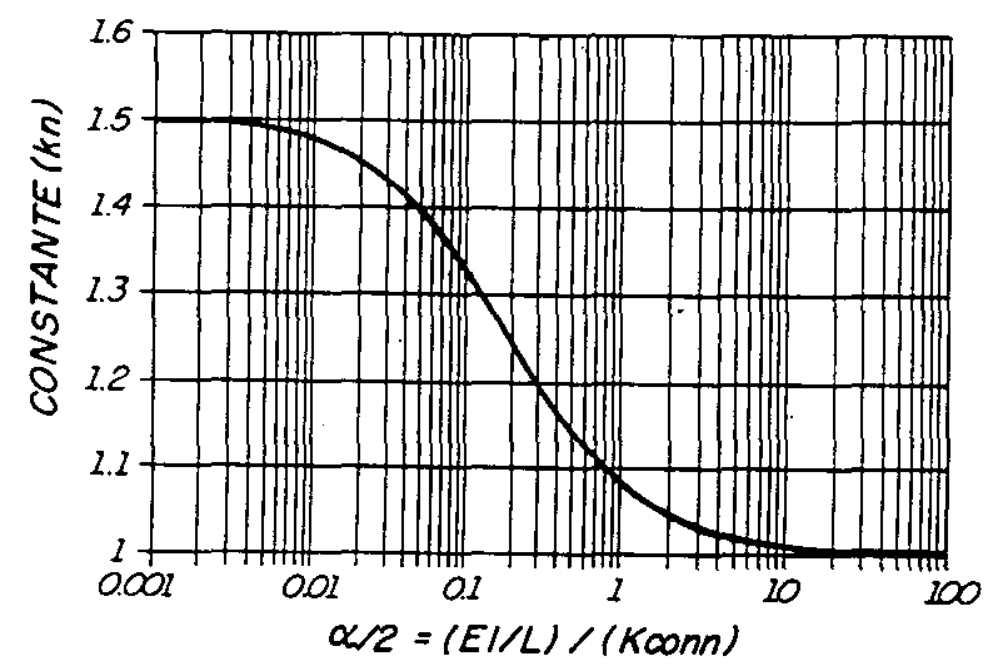

Figura 4.1 - Correção da Frequência Natural de Vigas.

Com a mesma metodologia encontra-se, para outros tipos de vigas:

$$
\begin{array}{ll}
\text { a - Em balanço: } & f=1,998 / \sqrt{\delta} \\
\text { b - Engaste e apoio: } & f=8,771 / \sqrt{\delta} \\
\text { c - Biengastada: } & f=12,723 / \sqrt{\delta}
\end{array}
$$

As vigas contínuas podem ser tratadas como se fossem biapoiadas, uma vez que os vãos adjacentes podem oscilar em direção oposta às oscilações do vão em estudo, não representando nenhuma restrição ou aumento de rigidez.

As equações anteriores são aplicáveis a vigas isoladas, mistas ou não, e a pisos formados por estas vigas, desde que dispostas em uma só direção, quando pode ocorrer a vibração de uma viga sem a contribuição das demais vigas. Nos pisos com vigas transversais a vibração de uma viga excita necessariamente, pelo menos, uma das vigas da outra direção, perpendicular à primeira. Para estes pisos a freqüencia natural pode ser determinada, pela expressão:

$$
f=\sqrt{\frac{1}{\frac{1}{f_{1}^{2}}+\frac{1}{f_{2}^{2}}}}
$$

onde $f_{1}$ e $f_{2}$ representam as freqüências naturais das vigas isoladas. 
Conhecida a freqüência, determina-se o período que, como já mostrado, é o inverso desta, ou seja:

$$
T=1 / f
$$

A vibração dos pisos pode ser induzida por várias fontes, bem diferentes das vibraçōes laterais do edifício que, comumente tem como causa o vento e muito excepcionalmente pequenos abalos sísmicos. Nos pisos as vibrações podem ser induzidas por máquinas, veículos e na maioria das vezes pelos usuários da edificação.

No caso das máquinas, o desbalanceamento das massas em movimento podem induzir vibraçöes contínuas, com comportamento senoidal, de freqüência e amplitudes variadas. Nestes casos, a melhor maneira para evitar que as vibrações se estendam aos pisos, consiste em isolar as bases destes equipamentos, ou por meio de um material absorvente ou então fazendo fundaçōes separadas.

No caso de vibrações induzidas por veículos pesados, que trafegam em locais próximos, não há muito o que fazer, uma vez que a eliminação das vibraçōes escapa ao poder de decisão do projetista de um edifício. Os pisos da edificação devem ser capazes de absorverem estas vibrações.

As atividades humanas, como dança, esporte, ginástica rítmica ou aeróbica, podem induzir freqüências das mais diversas, desde 1 até quase $10 \mathrm{Hertz}$. O caminhar normal das pessoas pode induzir freqüências de até 5 Hertz. Estas vibrações não podem ser evitadas, no entanto, elas também devem ser absorvidas pelos pisos.

A percepção humana para vibrações em pisos, bem como o limiar do desconforto, variam muito de uma pessoa para outra. Após vários estudos, Morris e Crede, Lenzen, Richer e Meister [38], conseguiram estabelecer uma certa relação entre esta percepção e o limiar do desconforto com a freqüência do movimento. Atualmente, é unânime a conclusão de que a maioria das pessoas é mais sensível a freqüências entre 2 e $8 \mathrm{Hertz}$, sendo que o limite corresponde a uma aceleração de aproximadamente $0,5 \mathrm{~g}$.

Como pode ser observado, pisos com freqüências naturais maiores que 10 Hertz não costumam apresentar vibrações incômodas. Entretanto, pisos com valores menores precisam de verificações adicionais, entre elas, a porcentagem do amortecimento crítico e a aceleraçāo de pico causada pelo impacto do calcanhar das pessoas ao andar, jogar ou dançar. 
A porcentagem do amortecimento crítico, para pisos com vigas de aço, pode ser estimada em cerca de $4 \%$ para estruturas não mistas e, de $2 \%$ para as mistas. Entretanto, como ressalva a NBR-8800, a colocação de tapetes, carpetes e demais revestimentos de pisos, forros, e dutos de ar condicionado, costuma acrescentar até $3 \%$ de amortecimento.

Como pode ser observado na figura 4.2, retirada da NBR-8800, os pisos não acabados possuem $3 \%$ do amortecimento crítico e os acabados $6 \%$ do mesmo amortecimento. Ainda segundo esta norma, a colocação de divisórias pode elevar esta porcentagem a até $12 \%$.

Quanto a aceleração de pico, identificada como " $a_{0}$ ", verifica-se que pode ser estimada por diversos processos. A NBR-8800 apresenta duas equações, que expressam esta aceleração em porcentagem da aceleração da gravidade g. A primeira expressão é aplicável a pisos executados com concreto normal. Esta expressão é:

$$
a_{0}=68800 f / L . t_{c}\left(t_{c}+25,4\right)
$$

onde: $f=$ freqüência natural do piso, em Hertz

$\mathrm{L}=$ vão do piso, em metros

$t_{c}=$ espessura efetiva do concreto, em milímetros

A segunda expressão, aplicável a pisos executados com concreto leve é:

$$
a_{0}=88500 f / L . t_{c}\left(t_{c}+25,4\right)
$$

cujas variáveis possuem as mesmas unidades e significado da expressão anterior.

Conhecidos os fatores $\mathbf{a}_{\mathbf{0}}$ e f é possivel verificar qual a porcentagem mínima de amortecimento crítico que o piso deve ter, por meio do gráfico, desenvolvido por Chen, que está incorporado na NBR-8800.

Como pode ser observado no gráfico, para freqüências menores que $8 \mathrm{Hertz}$ a única manéira de diminuir o limiar do desconforto é por meio da redução de $a_{0}$. E, pela análise das expressões, conclui-se ser muito mais eficiente, para a redução de $a_{0}$, o aumento da espessura do concreto portanto da massa do sistema - do que a redução da freqüência, obtida com a redução da rigidez, que aumentará a flecha estática. 
A análise anterior é aplicável a pisos com vãos maiores que 7,5 metros. Para vãos menores costuma ser suficiente a limitação da flecha estática, conforme preconiza o anexo C da NBR-8800.

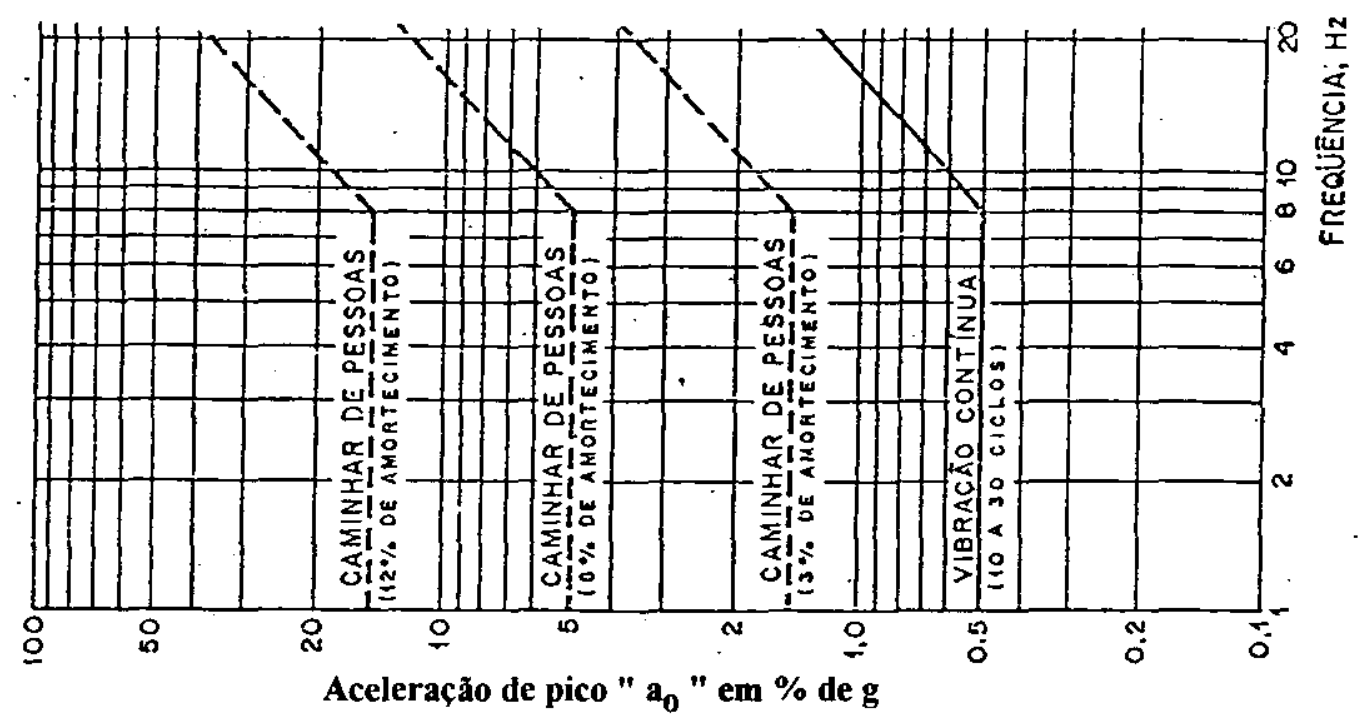

Figura 4.2 - Gráfico de Conforto Humano

\section{3- EDIFÍCIO EXEMPLO}

Como já descrito no capítulo inicial, os sistemas estruturais evoluíram para atender à necessidade social de construçōes cada vez mais altas.

Entretanto, o primeiro sistema empregado foi, e continua sendo, a solução mais viável e a mais empregada para construçōes de pequena altura.

Este sistema, constituído por pórticos dispostos em planos, quase sempre ortogonais entre sí, denominado de aporticado, possui realmente diversas qualidades que o tornam uma solução estrutural clássica, para as estruturas de aço.

Dentre estas 'qualidades, talvez a mais importante seja a sua simplicidade de formação, que permite a decomposição do seu comportamento espacial, nos diversos sistemas planos que o formam, possibilitando uma análise menos trabalhosa, portanto mais rápida $e$ economica, sem nenhum prejuizo da coerência ou da exatidão. 
Outro fator que predispõe este sistema a ser muito empregado, é a intensa aplicação didática do mesmo nos cursos de graduação, nos de pósgraduação e nas disciplinas específicas, quase sempre de cunho restrito, não de formação geral em estruturas.

Deve ser também lembrado, mais uma vez, que muitas construções inicialmente previstas em concreto armado, são erroneamente adaptadas para o aço, quando então o sistema aporticado parece o mais indicado, pois reflete melhor a linguagem do concreto.

Acredita-se ter ficado bem claro, que um projeto concebido para ter uma estrutura em concreto armado, não deve ter a substituição pura e simples do material estrutural, mantendo as demais características. Quando for necessário esta substituição é aconselhável uma revisão total do aspecto arquitetônico, pois os dois materiais possuem características muito distintas, que não se coadunam com meras substituições.

Nos sistemas aporticados em aço, além da sua simplicidade de formaçāo, deve ser muito bem explorada a característica de leveza dos seus elementos, evidenciada pela pequena relação altura/vão das vigas e dos pilares.

Nas construções que não possuem elevadores ou demais torres de serviço, que eventualmente podem ser transformados em núcleos resistentes, costuma-se dispor os pórticos segundo duas direçōes, procurando manter todos com as mesmas seçōes transversais, pois como já descrito, a padronização do material reduz bastante o custo da mão-deobra.

Quanto à disposição dos pilares, que deve respeitar a arquitetura da edificação, procura-se colocar o eixo de maior inércia da seção transversal do perfil, segundo o eixo da edificação que contar com o menor número de pilares.

Para as ações verticais, a posição relativa dos pilares não influencia em quase nada o comportamento estrutural, pois neste caso, a simples consideração da continuidade dos perfis que formam os pilares é condição suficiente para garantir a estaticidade do sistema.

Entretanto, para resistir às ações horizontais, torna-se necessário o aumento desta estaticidade, que pode ser conseguido com o engaste das vigas nas colunas. Este engastamento acaba resultando em uma transferência de momento das vigas para os pilares, que precisam de uma maior inércia para bem resistir a esta nova solicitaçāo. 
A diferença entre as inércias do pilar com vigas rotuladas e o pilar com vigas engastadas, pode ser expressa em têrmos da diferença do consumo de aço entre os dois perfis, podendo-se denominar a esta diferença como consumo de material destinado a resistir às açōes horizontais.

De um modo geral, um sistema é economicamente viável até o instante em que a parcela destinada a resistir às ações horizontais não ultrapassa a destinada a resistir às ações verticais.

No caso do sistema aporticado, este limite costuma ser atingido nas construções com um número de andares acima de 10, que é muito mais do que se pode construir sem a inclusão de elevadores de pessoas, que permitem a adoção de outros sistemas estruturais.

Uma vez definidos os pórticos, com a escolha das vigas do piso que podem ser engastadas, definidas as ações e suas combinações, pode ser feita a determinação das solicitações na estrutura e a verificação da capacidade resistente das barras.

Esta última fase é, como se sabe, um procedimento iterativo, pois caso se substituam algumas barras, porque estavam sub ou superdimensionadas, é aconselhável refazer a determinação das solicitações, entrando-se com os valores das novas barras, até que todas estejam dentro dos limites de segurança recomendado.

Visando exemplificar tudo que já foi escrito, será desenvolvido o dimensionamento de uma estrutura, esquematizada na figura seguinte, destinada a um edifício comercial, com $900 \mathrm{~m}^{2}$ de área construída por andar e com 20 pavimentos.

Como ponto de partida, assume-se que a disposição dos pilares e das vigas dos pisos, possa ser adotada a apresentada na figura, para o sistema estrutural aporticado. Para outros sistemas, que serão discutidos mais à frente, esta disposição poderá ser alterada.

Ainda dentro das hipóteses iniciais de pré-dimensionamento, vale lembrar que a colocação das vigas $\mathrm{V} 1$ visa reduzir a espessura das lajes, aliviando consequentemente o peso próprio dos pisos.

Quanto à espessura destas lajes, a mesma pode ser inicialmente assumida como a definida pela NBR 6118, em função da esbeltez, que pode conduzir a valores menores que a altura dos conectores comumente usados para a execução do sistema misto. Caso isto ocorra, pode ser aumentada esta espessura, ou então realizada a troca dos conectores 
Os conectores tipo pino com cabeça possuem altura elevada e exigem um recobrimento alto, em comparação com outros tipos como perfis laminadas ou em chapas dobradas, em $U$ ou cantoneiras.

Para a avaliação das ações que devem solicitar esta estrutura, tornam-se necessárias algumas outras suposições além do tipo de laje, como o material de vedação, a presença de revestimentos, de divisórias fixas ou removiveis, de forro, instalações, serviços, etc.
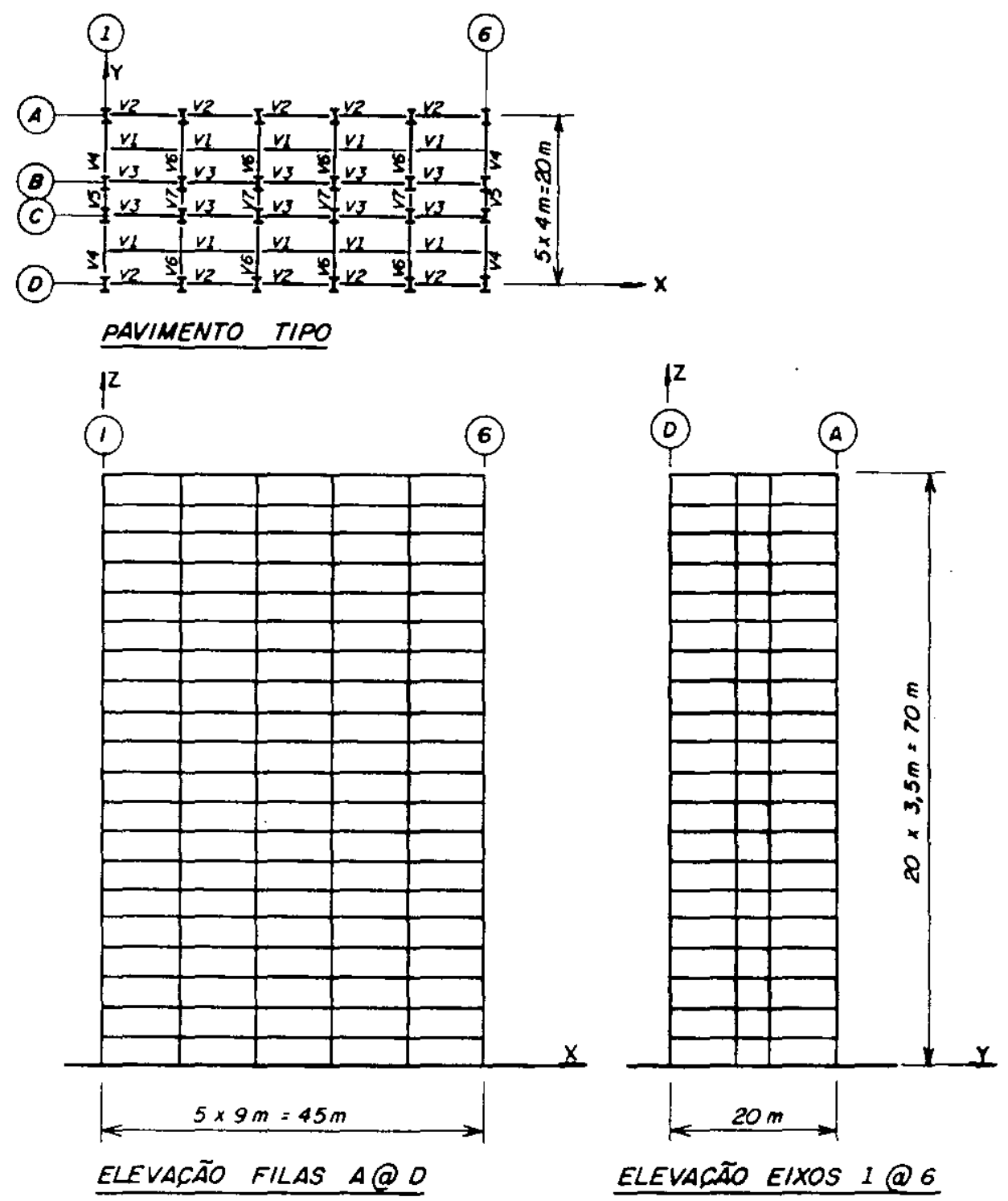

Figura 4.3 - Edifício Modelo

Em uma situação real, muitas destas variáveis são definidas no projeto de arquitetura ou de serviços, mas os valores não fogem muito dos apresentados a seguir, retirados da NBR-6120, da NBR-6123 e de algumas construçōes já executadas. 


\section{a- Peso Próprio dos Pisos:}

a-1- Vigas de aço

a.2-Laje de concreto $\left(h_{c}=8 \mathrm{~cm}\right)$

a.3-Argamassa de nivelamento $(3 \mathrm{~cm})$

a.4-Revestimento (carpete)

a.5-Fôrro e serviços

a.6-Divisórias móveis

a.7-Peso de formas (construção)
$=0,70 \mathrm{kN} / \mathrm{m}$

$=2,00 \mathrm{kN} / \mathrm{m}^{2}$

$=0,60 \mathrm{kN} / \mathrm{m}^{2}$

$=0,05 \mathrm{kN} / \mathrm{m}^{2}$

$=0,50 \mathrm{kN} / \mathrm{m}^{2}$

$=1,00 \mathrm{kN} / \mathrm{m}^{2}$

$=1,00 \mathrm{kN} / \mathrm{m}^{2}$

\section{b- Peso Próprio na Cobertura:}

b. 1-Vigas de aço

b. 2 -Laje de concreto $\left(h_{c}=7 \mathrm{~cm}\right)$

b.3-Impermeabilização

b.4-Forro e serviços
$=0,70 \mathrm{kN} / \mathrm{m}$

$=1,75 \mathrm{kN} / \mathrm{m}^{2}$

$=0,75 \mathrm{kN} / \mathrm{m}^{2}$

$=0,50 \mathrm{kN} / \mathrm{m}^{2}$

\section{c- Peso Próprio de Paredes Externas:}

Considerando a utilização de caixilhos metálicos com vidro duplo, persianas e/ou cortinas, pode ser adotado o valor máximo de 3,0 $\mathrm{kN}$ por metro linear de parede.

d- Sobrecargas de utilizacãa:

Tanto nos pisos como na cobertura será aplicado o valor de $2,0 \mathrm{kN} / \mathrm{m}^{2}$.

Para o dimensionamento dos pilares será feita a redução que a NBR6120 permite fazer.

$\begin{array}{ll}\text { Até três pavimentos } & =0 \% \\ \text { Até quatro pavimentos } & =20 \% \\ \text { Até cinco pavimento } & =40 \% \\ \text { Seis ou mais pavimentos } & =60 \%\end{array}$

Chegando-se a redução percentual média de $52 \%$, que será o valor utilizado para todos os pilares abaixo do $16^{\circ}$ pavimento. 
e - Vento

Para esta açăo, pode-se supor como sendo crítica a seguinte situação:

$$
\begin{aligned}
& V_{0}=40 \mathrm{~m} / \mathrm{s} \\
& \mathrm{S}_{1}=\mathrm{S}_{3}=1,0
\end{aligned}
$$

Determinando-se o fator $S_{2}$ para variações de $3,5 \mathrm{~m}$ que coincidem com os pisos dos andares, para categoria IV, classe $\mathrm{C}$, como mostrado no quadro seguinte.

Para determinar o coeficiente de arrasto, precisa-se das relações:

$$
\begin{aligned}
& h / \ell_{1}=70 / 20=3,5 \\
& \ell_{1} / \ell_{2}=20 / 45=0,44
\end{aligned}
$$

para vento incidindo na face menor, quando então encontra-se:

$$
\mathrm{C}_{\mathrm{a}}=0,85
$$

e, para a face maior

$$
\begin{aligned}
& \mathrm{h} / \ell_{1}=70 / 45=1,56 \\
& \ell_{1} / \ell_{2}=45 / 20=2,25 \\
& \mathrm{C}_{\mathrm{a}}=1,10
\end{aligned}
$$

e, as forças de arrasto, que incidem em cada face ao nivel das lajes, estão indicadas no quadro a seguir, assim como os valores de S2:

Lembrando que:

$$
\begin{aligned}
& S_{2}=\operatorname{br}(z / 10) p \\
& V_{k}=V_{0} S_{1} S_{2} S_{3}(\mathrm{~m} / \mathrm{s}) \\
& q=0,0613 V_{k}^{2} / 1000\left(\mathrm{kN} / \mathrm{m}^{2}\right) \\
& H_{i}=C_{a} A_{i} q
\end{aligned}
$$

Expressões retiradas da NBR-6123, assim como os fatores $F_{R} ; b ; p$. 
Os valores das forças $H_{i}$ foram divididos pelo número de pórticos resistentes na direção de atuação do vento, pois considera-se que as lajes, atuando como diagragmas rígidos no seu plano, igualem os deslocamentos de todos os pórticos que, por possuírem a mesma flexibilidade, apresentarão a mesma força de reação.

\begin{tabular}{|c|c|c|c|c|c|}
\hline$z_{(m)}$ & $s_{2}$ & $V_{k}(m / s)$ & $q\left(\mathrm{kN} / \mathrm{m}^{2}\right)$ & $\begin{array}{c}\text { Face menor } \\
\mathrm{H}_{\mathrm{i}} / 4(\mathrm{kN})\end{array}$ & $\begin{array}{c}\text { Face maior } \\
H_{\mathrm{i}} / 6(\mathrm{kN})\end{array}$ \\
\hline 3,5 & 0,693 & 27,7 & 0,47 & 7,0 & 13,6 \\
\hline 7,0 & 0,761 & 30,4 & 0,57 & 8,5 & 16,5 \\
\hline 10,5 & 0,803 & 32,1 & 0,63 & 9,4 & 18,2 \\
\hline 14,0 & 0,835 & 33,4 & 0,68 & 10,1 & 19,6 \\
\hline 17.5 & 0,861 & 34,4 & 0,73 & 10,9 & 21,1 \\
\hline 21,0 & 0,882 & 35,3 & 0,76 & 11,3 & 22,0 \\
\hline 24,5 & 0,901 & 36,0 & 0,80 & 11,9 & 23,1 \\
\hline 28.0 & 0.917 & 36,7 & 0,83 & 12,3 & 24,0 \\
\hline 31,5 & 0,932 & 37,3 & 0,85 & 12,7 & 24,6 \\
\hline 35,0 & 0,945 & 37,8 & 0,88 & 13,1 & 25,4 \\
\hline 38,5 & 0,957 & 38,3 & 0,90 & 13,4 & 26,0 \\
\hline 42,0 & 0,969 & 38,7 & 0,92 & 13,7 & 26,6 \\
\hline 45,5 & 0,979 & 39,2 & 0,94 & 14,0 & 27,1 \\
\hline 49,0 & 0,989 & 39,6 & 0,96 & 14,3 & 27,7 \\
\hline 52,5 & 0,998 & 39,9 & 0,98 & 14,6 & 28,3 \\
\hline 56,0 & 1,007 & 40,3 & 1,00 & 14,9 & 28,9 \\
\hline 59,5 & 1,015 & 40,6 & 1,01 & 15,1 & 29,2 \\
\hline 63,0 & 1,023 & 40,9 & 1,03 & 15,3 & 29,8 \\
\hline 66,5 & 1,031 & 41,2 & 1,04 & 15,5 & 30,0 \\
\hline 70.0 & 1,038 & 41,5 & 1,06 & 15,7 & 30,6 \\
\hline \multicolumn{4}{|c|}{ Total } & 253,7 & 492,3 \\
\hline
\end{tabular}

No caso em estudo, devido à dupla simetria elástica e geométrica, a resultante das forças $\mathrm{H}_{\mathrm{i}}$ passa pelo centro elástico da construção, causando apenas translações nos andares.

Entretanto, em casos como este, em que nāo existe excentricidade real do carregamento, a NBR-6123 no item 6.6.2, recomenda a aplicação das excentricidades teóricas já comentados no item 3.3.g. 
Devido ao crescimento urbano, as construçöes sem efeito de vizinhança, cedo ou tarde acabam tendo, sendo indicado, dimensioná-las para o caso crítico, que é com efeitos de vizinhança.

Deste modo, encontra-se:

$$
\begin{aligned}
& e_{a}=0,15 a=6,75 m \\
& e_{b}=0,15 b=3,00 m
\end{aligned}
$$

sendo a e b, respectivamente, a maior e a menor das dimensões laterais da construção.

Caso a análise computacional seja feita em programa espacial, as informações levantadas já são suficientes. Caso não se disponha de um programa deste tipo, ou caso a quantidade de barras necessárias para definir a estrutura ultrapasse a capacidade do programa, pode ser feita uma análise plana, com a composição final dos resultados, simulando assim a análise tridimensional.

Em qualquer análise, plana ou tridimensional, o momento de torção, como se sabe, será equilibrado por forças horizontais, desenvolvidas em cada pórtico, diretamente proporcionais à rigidez e à distancia de cada um ao centro elástico da estrutura.

As intensidades destas forças horizontais podem ser determinadas pelas clássicas expressões:

$$
\begin{aligned}
& F_{i x}=M_{T} R_{i x} y_{i} / \sum R_{i x} y_{i}^{2}+\sum R_{i y} x_{i}^{2} \\
& F_{i y}=M_{T} R_{i y} x_{i} / \sum R_{i x} y_{i}^{2}+\sum R_{i y} x_{i}^{2}
\end{aligned}
$$

Verifica-se, pelas equações anteriores, que é necessário conhecer, além do valor do momento de torção, a rigidez e a posição relativa de cada pórtico, até o centro elástico, tanto no plano xz como no plano yz.

Para determinar a rigidez de cada pórtico, bem como a posição do centro elástico, é nẹcessário ter inicialmente uma estrutura, ou seja, é necessário um predimensionamento de todas as barras que a compõe, o que já é perfeitamente passível de ser feito, partindo-se dos valores anteriormente apresentados como prováveis de ocorrer para as ações, como será mostrado a seguir. 


\subsection{1 - Vigas dos Pisos}

Analisando as vigas dos pisos, admitindo-se que serão em seção mista aço/concreto, com iteração parcial e sem escoramento durante a fase de cura do concreto, ficam definidos dois carregamentos básicos, a saber:

-O primeiro, que solicita apenas a viga metálica, enquanto o concreto não atinge a $75 \%$ da resistência do $f_{c k}$.

-O segundo, que solicita a viga mista, quando a resistência do concreto excede aquele valor.

Considerando que só as vigas longitudinais recebam as ações oriundas das lajes, em função da relação $\ell_{1} / \ell_{2}$ ser maior que 2,0 o que permite considerá-las armadas em uma direção, encontra-se para os momentos no meio do vão da viga $V 1$, simplesmente apoiada, em carregamento específico para o período da construção:

$$
M_{\mathrm{d} 1}=\left(1,2 p_{1}+1,3 p_{2}+1,3 p_{3}\right) \ell^{2 / 8}
$$

onde: $p_{1}=0,7 \mathrm{kN} / \mathrm{m}$ ( peso próprio da viga de aço )

$p_{2}=4 \times 2=8 \mathrm{kN} / \mathrm{m}$ ( peso próprio das lajes)

$p_{3}=1,0 \mathrm{kN} / \mathrm{m}$ ( peso do escoramento das lajes, supostos apoiados ao longo da viga - não soma seus efeitos a $M_{d 2}$ nem a $M_{2}$ )

Substituindo encontra-se:

$$
M_{\mathrm{d} 1}=12.697 \mathrm{kN} . \mathrm{cm}
$$

Para a escolha do perfil, pode-se utilizar o critério da rigidez à flexão, para determinar a inércia que o mesmo deve ter, para que não seja necessário encomendá-lo com contra-flecha, ou seja, que sua relaçāo flecha/vão devida às solicitações da fase de construção atenda ao limite:

$$
\delta / \ell \leq 1 / 1000 \text { ( Padräo II - FEM [ 11]) }
$$

sendo $\delta$ calculado com os valores nominais das ações, ou seja:

$$
\delta=5 \mathrm{p}_{\mathrm{i}} \ell^{4} / 384 \mathrm{El} \geq \ell / 1000
$$

Portanto: $\quad 1 \geq 44.900 \mathrm{~cm}^{4}$ 
Adota-se como primeira tentativa o perfil VS $500 \times 73$, cuja inércia é de $42.768 \mathrm{~cm}^{4}$, próxima da mínima e cuja resistência isolada será determinada, segundo a NBR-8800, tanto para FLA, FLM e FLT:

a- Estabilidade da mesa comprimida:

$$
\begin{aligned}
& \lambda_{m}=b / 2 t=250 / 2 \times 12,5=10 \\
& \lambda_{p}=0,38 \sqrt{E / f_{y}}=10,88>\lambda_{m}
\end{aligned}
$$

Portanto não ocorre instabilidade e, $M_{n}=M_{p \ell}$.

b- Estabilidade da Alma:

$$
\begin{aligned}
& \lambda_{a}=h_{w} / t_{w}=475 / 6,3=75 \\
& \lambda_{p}=0,35 \sqrt{E / f_{y}}=100>\lambda_{a}
\end{aligned}
$$

Também não ocorre instabilidade e mais uma vez $M_{n}=M_{p \ell}$

c- Estabilidade Lateral do Perfil;

$$
\begin{aligned}
& \lambda_{\mathrm{FLT}}=\mathrm{Lb} / \mathrm{r}_{\mathrm{y}}=900 / 5,94 \cong 151,5 \\
& \lambda_{\mathrm{p}}=1,75 \sqrt{\mathrm{E} / \mathrm{f}_{\mathrm{y}}}=50<\lambda_{\mathrm{FLT}}
\end{aligned}
$$

Para o cálculo de $\lambda_{\mathrm{R}}$, precisa-se determinar antes:

$$
\begin{aligned}
& \beta_{1}=\pi \sqrt{\mathrm{GEAl}_{\mathrm{t}}}=2.319 .880 \mathrm{kN} \mathrm{cm} \\
& \beta_{2}=6,415 \mathrm{~A}\left(\mathrm{~d}-\mathrm{t}_{\mathrm{f}}\right)^{2} / \mathrm{I}_{\mathrm{t}}=38.583
\end{aligned}
$$

com estes valores encontra-se:

$$
\lambda_{R}=\frac{0,707 \beta_{1}}{M_{R}} \sqrt{1+\sqrt{\left(1+4 \beta_{2} M_{R}^{2}\right) / \beta_{1}^{2}}}=159,4>\lambda \mathrm{FLT}
$$

Os valores quase comcidem, porém deve-se calcular $M_{n}$ pela equação:

$$
M_{n}=M_{p \ell}-\left(M_{p \ell}-M_{R}\right) \frac{\lambda_{F L T}-\lambda_{p}}{\lambda_{R}-\lambda_{p}}=23.055 \mathrm{kN} \mathrm{cm}
$$

Sendo este valor o crítico, pois é menor que os outros dois. 
A condição de segurança é definida como:

$$
\phi_{b} M_{n} \geq M_{d}
$$

com $\phi_{b}=0,9$ encontra-se: $\quad \phi_{b} M_{n}=20.750 \mathrm{kN} . \mathrm{cm}>M_{d 1}$

Portanto, a viga atende às condições de segurança quanto ao momento fletor, causado pelas ações iniciais.

Fazendo a verificação ao esforço cortante calcula-se:

$$
\begin{aligned}
& \lambda_{a}=75,4 \\
& \lambda_{p}=1,08 \sqrt{k \cdot E / f_{y}}=71,46<\lambda_{a} \\
& \lambda_{R}=1,40 \sqrt{k \cdot E / f_{y}}=92,64>\lambda_{a} \\
& \phi_{V} V_{n}=\phi_{V} V_{p \ell} \lambda_{p} / \lambda_{a}=153 \mathrm{kN} \\
& V_{d}=\left(1,2 p_{1}+1,3 p_{2}+1,2 p_{3}\right) 9 / 2=56 \mathrm{kN}<\phi_{V} V_{d}
\end{aligned}
$$

Portanto também atendida.

Quanto à flecha máxima, encontra-se $\delta=0,95 \mathrm{~cm}$ que representa $1 / 950$ do vão, indicando que o perfil não precisa de pré-deformação de fabricação, uma vez que os valores praticamente coincidem.

Fazendo agora a verificação da seção mista, segundo o item 6.2.3.2 da NBR-8800 calculam-se inicialmente os valores:

$$
\begin{aligned}
& b=16 h_{c}=16 \times 8=128 \mathrm{~cm} \\
& Q_{n} \geq A f_{y} / 2=92,4 \times 25 / 2 \cong 1.155 \mathrm{kN}
\end{aligned}
$$

Adotando-se: $Q_{n}=1300 \mathrm{kN}$, encontra-se:

$$
\begin{aligned}
& C=(0,7 / 0,9) Q_{n}=1.010 \mathrm{kN} \\
& d=C / 0,66 f_{c k} \cdot b=3,42 \mathrm{~cm} \quad\left(f_{c k}=3,5 \mathrm{kN} / \mathrm{cm}^{2}\right) \\
& C^{\prime}=\left[\left(A f_{y}\right)_{a}-C\right] / 2=650 \mathrm{kN}<\left(A f_{y}\right)_{m} \\
& \bar{y}=\left[c^{\prime} /\left(A f_{y}\right)_{m}\right] t_{f}=1,04 \mathrm{~cm}<t_{f} \\
& y_{t}=(50-1,04) / 2=24,48 \mathrm{~cm} \\
& y_{c}=\bar{y} / 2=0,52 \mathrm{~cm}
\end{aligned}
$$


chegando-se a:

$$
\begin{aligned}
& M_{n}=C^{\prime}\left(d-y_{t}-y_{c}\right)+C\left(d+h_{f}+t_{c}-\frac{a}{2}-y_{t}\right) \\
& M_{n}=16.250+32.128=48.378 \mathrm{kN} \cdot \mathrm{cm}
\end{aligned}
$$

Portanto: $\quad \phi_{b} M_{n}=43.540 \mathrm{kN} . \mathrm{cm}$

O valor do momento de cálculo que atua na viga mista, é calculado com as açōes nāo aplicadas na combinação de construçāo, em carregamento específico para a vida útil da estrutural, ou seja, normal:

$$
M_{d 2}=\left(1,4 p_{4}+1,5 p_{5}\right) 9^{2} / 8
$$

onde:

$$
\begin{aligned}
& p_{4}=(0,6+0,05+0,5+1,0) 4=8,6 \mathrm{kN} / \mathrm{m} \text { ( são as ações devidas } \\
& \text { ao acabamento do piso ). } \\
& p_{5}=2 \times 4=8 \mathrm{kN} / \mathrm{m} \text { ( carga acidental) }
\end{aligned}
$$

Substituindo encontra-se:

$$
M_{d 2}=24.340 \mathrm{kN} \cdot \mathrm{cm}
$$

que é um valor bem menor que o momento resistente (56\%). Portanto mais uma verificação atendida.

A última verificação que A NBR-8800 exige, deve-se à opção de adotar iteração parcial entre a laje e a viga de aço. Esta verificação é feita em regime elástico e no caso desta viga que possui;

$$
h_{w} / t_{w}<3,5 \sqrt{E / f_{y}}
$$

com os valores nominais das açōes.

Devem ser analisadas as fibras inferiores da viga metálica para evitar tensões acima do limite de escoamento, por meio da expressão:

$$
\sigma_{t}=M_{G}^{\prime} / w_{a}+M_{L} / w_{e f} \leq 0,9 f_{y}
$$

onde: $\mathbf{M}_{\mathrm{a}}^{\prime}=$ Momento devido às ações aplicadas antes do concreto atingir a resistencia de $0,75 f_{c k}$, ou seja, na viga isolada.

$\mathrm{M}_{\mathrm{L}}=$ Momento devido às açōes aplicadas após o concreto atingir a resistência de $0,75 f_{c k}$, ou seja na viga mista. 
$\mathrm{W}_{\mathrm{a}}=$ Módulo de resistência à flexăo, elástico, da viga de aço.

$W_{\text {ef }}=$ Módulo de resistência à flexão da seção mista homogeneizada, em estado elástico e levando em conta o deslizamento da superfície de contato aço/concreto.

Sendo: $W_{\text {ef }}=W_{a}+\sqrt{\frac{Q_{n}}{V_{n}}}\left[\left(W_{t r}\right)_{i}-W_{a}\right]$

com: $V_{h}=\left(A f_{y}\right) a$

$\left(W_{t r}\right)_{i}=$ Módulo de resistência teórico da seção mista homogeneizada.

Para a viga em estudo, a seção transversal é a da figura seguinte::

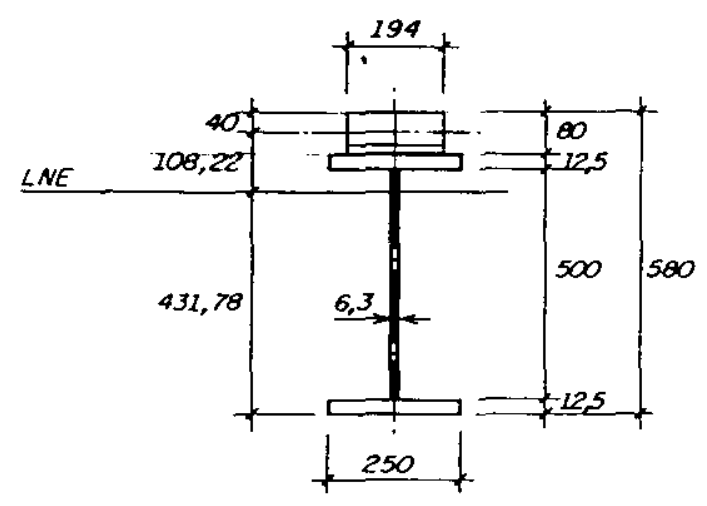

Figura 4.4 - Seção da Viga Mista.

$$
\text { com: } \quad \begin{aligned}
\mathrm{f}_{\mathrm{ck}} & =35 \mathrm{MPa} \\
\gamma_{\mathrm{c}} & =25 \mathrm{kN} / \mathrm{m}^{3} \\
\mathrm{E}_{\mathrm{c}} & =42 \gamma_{\mathrm{c}}^{1,5} \sqrt{\mathrm{f}_{\mathrm{ck}}}=31.060 \mathrm{MPa} \\
\mathrm{n} & =\mathrm{E}_{\mathrm{a}} / \mathrm{E}_{\mathrm{c}}=6,6 \\
\mathrm{I}_{\mathrm{r}} & =92.300 \mathrm{~cm}^{4} \\
\left(\mathrm{~W}_{\mathrm{tr}}\right)_{\mathrm{s}} & =6.227 \mathrm{~cm}^{3} \\
\left(\mathrm{~W}_{\mathrm{tr}}\right)_{\mathrm{i}} & =2.138 \mathrm{~cm}^{3} \\
\mathrm{~W}_{\mathrm{a}} & =1.711 \mathrm{~cm}^{3}
\end{aligned}
$$

Portanto: $W_{\text {ef }}=1.950 \mathrm{~cm}^{3}$

$$
\begin{aligned}
& \mathrm{M}_{\mathrm{G}}=8.810 \mathrm{kN} . \mathrm{cm} \\
& \mathrm{M}_{\mathrm{L}}=16.810 \mathrm{kN} . \mathrm{cm}
\end{aligned}
$$


que substituidos na expressão de iteração conduzem a:

$$
\sigma_{\mathrm{t}}=5,15+8,62=13,77 \mathrm{kN} / \mathrm{m}<0,6 \mathrm{f}_{\mathrm{y}}
$$

Portanto, a viga atendeu a todas as verificaçōes e a menos da flecha inicial, com relativa folga.

Quanto às vigas V2, que estão sob os mesmos carregamentos, porém em esquema estrutural biengastado, os momentos de cálculo no meio do vão são:

$$
\begin{aligned}
& M_{d 1}=4.230 \mathrm{kN} \cdot \mathrm{cm} \\
& M_{d 2}=8.120 \mathrm{kN} . \mathrm{cm}
\end{aligned}
$$

e, os momentos nominais nos apoios:

$$
\begin{aligned}
& M_{1}=6.550 \mathrm{kN} . \mathrm{cm} \\
& M_{2}=11.210 \mathrm{kN} . \mathrm{cm}
\end{aligned}
$$

Pelos valores dos momentos atuantes pode parecer interessante utilizar um perfil menor, porém a redução da altura ou da largura das mesas,

\begin{tabular}{|c|c|c|c|c|}
\hline VIGA & $M_{1}$ & $M_{2}$ & $M_{d 1}$ & $M_{d 2}$ \\
\hline$V_{1}$ & 8.810 & 16.810 & 12.260 & 24.340 \\
\hline V2 & 3.175 & 7.630 & 2.200 & 5.475 \\
\hline v3 & 5.875 & 11.210 & 4.090 & 8.115 \\
\hline V4 & 4.475 & 7.470 & 6.180 & 13.220 \\
\hline V5 & Admitida & sem & ações & verticais \\
\hline V6 & 8.390 & 14.940 & 11.630 & 21.640 \\
\hline v7 & Admitida & sem & ações & verticais \\
\hline
\end{tabular}
embora represente economia em peso, causaria transtornos nas ligaçōes, nos caminhos de dutos, forros, etc. Portanto, por razões construtivas será utilizado o VS $500 \times 73$ também nas demais vigas, uma vez que suas solicitaçōes, conforme o quadro seguinte resume, ficam atendidas.

No quadro anterior, os valores de $M_{1}$ e $M_{d 1}$ foram calculados sem a ação dos pesos das formas, uma vez que a mesma não se soma às demais e com os coeficientes de ponderação das ações para combinações normais. 
Vale lembrar que só a viga V1 é simplesmente apoiada, as demais são biengastadas, portanto no quadro anterior os valores do meio do vão são de cálculo e os dos apoios nominais, consequentemente negativos, ou seja, a viga metálica é comprimida e a laje tracionada.

Antes de assumir qualquer postura, devem ser analisadas as tensões nominais, que estão ocorrendo nas fibras mais distantes da linha neutra elástica, da seção homogeneizada, que na viga V6, a mais solicitada são:

$$
\begin{aligned}
& \sigma_{\mathrm{c}}=M_{1} / W_{\mathrm{a}}+M_{2} / W_{\mathrm{ef}}=12,57 \mathrm{kN} / \mathrm{cm}^{2}<0,6 \mathrm{f}_{\mathrm{y}} \\
& \sigma_{\mathrm{t}}=M_{2} / \mathrm{n}\left(W_{\mathrm{tr}}\right)_{\mathrm{s}}=0,36 \mathrm{kN} / \mathrm{cm}^{2}>\mathrm{f}_{\mathrm{tk}}=0,28 \mathrm{kN} / \mathrm{cm}^{2}
\end{aligned}
$$

O valor de $\mathbf{f}_{\mathbf{f k}}$ foi calculado segundo o item 5.2.1.2 da NBR-6118.

Em função do valor encontrado para $\sigma_{\mathfrak{t}}$, que é maior que a resistencia à tração do concreto, cabem as seguintes observações:

1-Segundo a NBR-8800, o momento negativo deve ser resistido apenas pela viga de aço e colocada armadura para evitar a fissuração do concreto. Neste caso, a verificação a ser feita é comparar o momento total de cálculo com o momento resistente da viga na região dos apoios, que é o de plastificação, uma vez que não ocorrem instabilidades locais. Portanto:

$$
\begin{aligned}
& M_{d}=33.270 \mathrm{kN} . \mathrm{cm} \\
& \phi_{n} M_{n}=\phi_{b} M_{p \ell}=42.270 \mathrm{kN} . \mathrm{cm}>M_{d}
\end{aligned}
$$

2-Segundo o LRFD [ 2 ], as tensões de tração podem ser absorvidas pela armadura da laje. Neste caso, admitindo-se que a armadura seja, na pior hipótese, a mínima pela NBR-6118, as tensōes seriam:

$$
\begin{aligned}
& A_{s t}=1,6 \mathrm{~cm}^{2} \\
& W_{i}=1.737 \mathrm{~cm}^{3} \\
& W_{s}=1.411 \mathrm{~cm}^{3} \\
& \sigma_{i}=19,26 \mathrm{~cm}^{2}<0,9 \mathrm{f}_{y} \\
& \sigma_{s}=15,34 \mathrm{kN} / \mathrm{cm}^{2}<f_{y} d
\end{aligned}
$$


3-Os dois procedimentos, neste caso em análise, mostram que a viga suporta o momento negativo que surge nos apoios, entretanto pode ocorrer a fissuração do concreto.

4-Aumentando a armadura da laje para evitar a fissuração, consegue-se um alívio nas tensões da viga e da própria armadura da laje.

Portanto, pode-se manter o perfil VS $500 \times 73 \mathrm{em}$ todas as vigas do piso e em regime elástico, considerarando como constante ao longo do vão, a inérica efetiva da seção mista homogeneizada, como recomenda o LRFD, ou a inérica da seção bruta, conforme a BS 5950 [ 13 ].

A última verificação das vigas é quanto à sua capacidade de absorver as vibraçōes introduzidas pelo caminhar das pessoas. A frequência natural das vigas dos eixos, que são biengastadas será:

$$
f_{1}=12,723 / \sqrt{\delta}
$$

E o valor da flecha é:

$$
\delta=p \ell^{4} / 384 \mathrm{EI}=0,253 \times 800^{4} / 384 \times 20.500 \times 92.300=0,142 \mathrm{~cm}
$$

Portanto: $f_{1}=33,69$ Hertz

Lembrando que entra-se com o valor de $\delta$ em centímetros.

As vigas $\mathrm{V} 1$, que são biapoiadas, e apoiam-se nas vigas dos pórticos, tem a frequência determinada pela expressão:

$$
f_{2}=\frac{5,61}{\sqrt{\delta}}
$$

Sendo o valor da flecha de: $\delta=0,1423 \mathrm{~cm}$

Portanto: $f_{2}=5,25$ Hertz

A frequência natural do piso será:

$$
f_{p}=\sqrt{\frac{1}{\frac{1}{f_{1}^{2}+\frac{1}{f_{1}^{2}}+\frac{1}{f_{2}^{2}}}}}
$$


E a aceleração de pico, que é determinada em função desta frequência, será:

$$
a_{O}=6800 f_{p} / L . t_{c}\left(t_{c}+25,4\right)=4,6 \% g
$$

Retirando-se do gráfico das figuras 3.6 ou da 4.2, extraídas de BLESSMAN [ 12 ] e da NBR-8800 [ 8 ] respectivamente, a informação de que 0 piso precisa ter $6 \%$ de amortecimento, que coincide com 0 valor sugerido e apresentado na tabela 32 da mesma norma. Portanto, o piso também atende a esta última verificação.

\subsection{2- Vigas da Cobertura}

Na maioria dos projetos, as vigas da cobertura costumam ser mais leves que as vigas do pavimento tipo. Esta redução, no peso e na resistência é possivel devido à menor intensidade das ações que costumam solicitar a cobertura, em relação às ações que solicitam os pavimentos tipos.

Entretanto, esta redução não deve ser tão grande a ponto de inviabilizar futuras destinaçōes da cobertura.

Determinando as solicitações nestas vigas, que estão apresentadas no quadro seguinte, pode-se observar que as solicitações não são muito inferiores às obtidas nas vigas dos pavimentos tipos.

\begin{tabular}{|r|r|r|r|r|}
\hline VIGA & \multicolumn{1}{|c|}{$\mathrm{M}_{1}$} & \multicolumn{1}{|c|}{$\mathrm{M}_{2}$} & \multicolumn{1}{c|}{$\mathrm{M}_{\text {d1 }}$} & \multicolumn{1}{c|}{$\mathrm{M}_{\text {d2 }}$} \\
\hline $\mathrm{V}_{1}$ & 7.800 & 13.165 & 10.845 & 19.240 \\
\hline V2 & 2.835 & 6.415 & 1.961 & 4.625 \\
\hline V3 & 5.200 & 8.780 & 3.615 & 6.410 \\
\hline V4 & 4.025 & 8.250 & 5.550 & 8.550 \\
\hline V6 & 7.490 & 11.700 & 10.370 & 17.100 \\
\hline
\end{tabular}

Os valores indicados permitem utilizar o perfil VS $500 \times 61$, em viga mista, com $7 \mathrm{~cm}$ de espessura na laje, cujas resistências de cálculo, determinadas na mesma sequência das vigas dos pisos sāo: 
a) Resistência de Cálculo do Perfil Isolado:

$$
\phi_{\mathrm{b}} M_{\mathrm{n}}=16.074 \mathrm{kN} \cdot \mathrm{cm}>M_{\mathrm{d} 1}
$$

Sendo este valor, que é o crítico, determinado pelo estado limite de flambagem lateral com torção.

b) Flecha na Viga Metálica Isolada:

$$
\delta=0,93 \mathrm{~cm}=\ell / 965
$$

c) Resistência como Viga Mista:

$$
\phi_{\mathrm{b}} \mathrm{M}_{\mathrm{n}}=34.815 \mathrm{kN} \cdot \mathrm{cm}>\mathrm{M}_{\mathrm{d} 2}
$$

d) Máxima Tensão na Fibra Inferior da Viga de Aço:

$$
\sigma=13,27 \mathrm{kN} / \mathrm{cm}^{2}<0,6 \mathrm{fy}
$$

Ficando deste modo pré-dimensionadas as lajes e vigas dos pisos e da cobertura, permitindo a determinação das propriedades geométricas de todos os elementos e por extensão também as dos pórticos.

\subsection{3- Colunas}

Para pré-dimensionar as colunas, admite-se que as seçōes variem a cada quatro andares e toma-se como indicação os esforços de compressāo dos pilares centrais, causados pelas ações de peso próprio e sobrecarga, sem redução alguma, que são:

10. Trecho: $\mathrm{Nd} 1=9.800 \mathrm{kN}$

20. Trecho: $\mathrm{Nd} 2=7.840 \mathrm{kN}$

3o. Trecho: $\mathrm{Nd} 3=5.880 \mathrm{kN}$

40. Trecho: $\mathrm{Nd} 4=3.920 \mathrm{kN}$

50. Trecho: $\mathrm{Nd} 5=1.960 \mathrm{kN}$ 
Considerando que ocorre flexão nos dois planos da seção, pode-se admitir, para efeito de estimativa da área que o perfil deve ter, que estes esforços representem $75 \%$ da resistência do perfil.

Com estas condições a área do perfil, em cada trecho, pode ser estimada como sendo de:

$$
A_{i}=N_{d i} / 0,75 \phi_{c} \rho f y
$$

com $\phi_{\mathrm{C}}=0,9$ e admitindo um índice de elbeltez próximo de 60 ou 70 , que deve corresponder a uma redução de $\rho \cong 0,7$ encontra-se:

$$
\begin{aligned}
& A_{1}=830 \mathrm{~cm}^{2} \\
& A_{2}=660 \mathrm{~cm}^{2} \\
& A_{3}=500 \mathrm{~cm}^{2} \\
& A_{4}=330 \mathrm{~cm}^{2} \\
& A_{5}=170 \mathrm{~cm}^{2}
\end{aligned}
$$

que permitem pré-selecionar os perfis para uma primeira verificação computacional.

No caso deste projeto, as solicitações de flexão no plano das filas, que possuem maior número de pilares e menor área exposta ao vento, serão menores que as despertadas no plano dos eixos, podendo ser adotados perfis da série CVS, mais economicos que os da série CS.

Entretanto, no perfil do primeiro trecho, em funçāo da área necessária ser muito superior à do maior perfil da série, será utilizada uma seção não padronizada, porém com as mesmas proporções dos perfis da série escolhida.

Como os valores das áreas definidos anteriormente, chega-se aos seguintes perfis:

$$
\begin{aligned}
& P_{1}=\text { CVS } 850 \times 630 \text { (não padronizado) } \\
& P_{2}=\text { CVS } 650 \times 461 \\
& P_{3}=\text { CVS } 650 \times 310 \\
& P_{4}=\text { CVS } 650 \times 211 \\
& P_{5}=\text { CVS } 500 \times 162
\end{aligned}
$$

que permitem determinar os esforços e os deslocamentos da estrutura prédimensionada. 


\section{4 - Estrutura Final}

Uma vez pré-dimensionada tas barras da estrutura, podem ser determinadas as solicitaçōes nestas barras e verificada a sua capacidade em suportar estas solicitações.

Como já descrito, na aplicação das ações do vento deve ser considerado o momento de torção, causado pela presença de construções na vizinhança.

A estrutura em análise é formada por pórticos tanto nos planos dos eixos como nos planos das filas. Deste modo, o momento de torção introduzirá solicitaçōes em todos os pórticos, inclusive naqueles perpendiculares à direção do vento.

A magnitude das solicitaçōes em cada pórtico depende da rigidez e da posição relativa de cada pórtico em relação ao centro elástico da estrutura.

Admitindo-se inicialmente que todos os pórticos possuam a mesma rigidez, a força de arrasto devida à incidência do vento pode ser considerada distribuida igualmente entre os diversos pórticos contidos na direção analisada.

Estes valores, denominados de iniciais, aplicados aos pórticos, permitem determinar os deslocamentos em cada trecho que cada um foi dividido e em último caso o deslocamento do topo.

Estes deslocamentos permitem a determinação de uma rigidez relativa dos pórticos, assumidas iniciaimente como iguais entre sí, como a razão entre estes deslocamentos e as forças aplicadas.

Esta rigidez relativa também pode ser avaliada, com suficiente precisão, como o resultado da divisão do total das forças horizontais aplicadas ao pórtico pelo deslocamento obtido no topo, ou seja:

$$
\mathrm{R}_{\mathrm{i}} \cong \sum \mathrm{H}_{\mathrm{i}} / \delta_{\mathrm{T}}
$$

As forças que o momento de torção desperta em cada pórtico permitem escrever:

$$
M_{T}=\sum R_{i y} \delta_{i y} x_{i}+\sum R_{i x} \delta_{i x} y_{i}
$$

ou entāo mais resumidamente: 


$$
M_{T}=M_{T x}+M_{T y}
$$

Sendo $M_{T x}$ e $M_{T y}$ as parcelas do momento de torção, que resultam da decomposição do mesmo, proporcionais ao somatório das rigidez dos pórticos de cada face da edificação.

Quanto aos deslocamentos do topo dos pórticos, acoplados entre si pela laje de cobertura, que deve funcionar como um diafragma, pode-se escrever:

$$
\theta=\delta_{\mathrm{ix}} / \mathrm{yi}=\delta_{\mathrm{iy}} / \mathrm{xi}
$$

sendo $\theta$ o ângulo que a laje forma, ao girar em torno do centro elástico, devido à atuação do momento de torção.

Multiplicando e dividindo a primeira relação da expressão ( 4.4 .3 ), por $R_{\mathrm{ix}}$. yi encontra-se:

$$
\theta=\frac{\delta_{\mathrm{ix}}}{\mathrm{y}_{\mathrm{i}}}=\frac{\delta_{\mathrm{ix}} \cdot \mathrm{R}_{\mathrm{ix}} \cdot \mathrm{y}_{\mathrm{i}}}{\mathrm{R}_{\mathrm{ix}} \cdot \mathrm{y}_{\mathrm{i}}^{2}}=\frac{\sum \mathrm{R}_{\mathrm{ix}} \cdot \mathrm{y}_{\mathrm{i}} \cdot \delta_{\mathrm{ix}}}{\sum \mathrm{R}_{\mathrm{ix}} \cdot \mathrm{y}_{\mathrm{i}}^{2}}=\frac{\mathrm{M}_{\mathrm{Tx}}}{\mathrm{I}_{\mathrm{x}}}
$$

que permite escrever:

$$
\delta_{i x}=\frac{M_{T x}}{I_{x}} y_{i}
$$

como: $\delta_{\mathrm{ix}}=F_{\mathrm{ix}} / \mathrm{R}_{\mathrm{ix}}$ igualando tira-se:

$$
F_{i x}=\frac{M_{T x}}{i_{x}} R_{i x} \cdot y_{i}
$$

Porém, pode-se relacionar:

$$
M_{T X}=\frac{M_{T x} \cdot I_{x}}{I_{x}+I_{y}}=\frac{M_{T x} \cdot I_{x}}{I_{p}}
$$

que substituido na equação ( 4.4 .6 ) fornece:

$$
F_{i x}=\frac{M_{T}}{I_{x}} R_{i x} \cdot y_{i}
$$


ou, finalmente:

$$
F_{i x}=\frac{M_{T} \cdot R_{i x} \cdot y_{i}}{\sum R_{i x} \cdot y_{i}^{2}+\sum R_{i y} \cdot x_{i}^{2}}
$$

e, por analogia:

$$
F_{i y}=\frac{M_{T} \cdot R_{i y} \cdot x_{i}}{\sum R_{i x} \cdot y_{i}^{2}+\sum R_{i y} \cdot x_{i}^{2}}
$$

A resultante a ser aplicada em cada pórtico é obtida como a soma vetorial de $H_{i}$ com $F_{i}$., Lembrando que as forças $H_{i}$ representam os somatórios das forças aplicadas inicialmente, que foram consideradas como concentradas, mas que foram determinadas pela pressão distrinuída ao longo da altura do edifício, segundo a lei de variação do perfil do vento.

As forças $F_{i}$, devem ser entendidas como os somatórios dos incrementos, positivos ou negativos, que a excentricidade de aplicação das forças $\mathrm{H}_{\mathrm{i}}$ provoca, portanto, obedecem à mesma lei de variação das forças $H_{i}$, uma vez que a excentricidade é considerada como constante ao longo da altura.

Desta forma, a resultante em cada pórtico pode ser assumida como uma combinaçāo linear das forças $H_{\mathbf{i}}$, o que significa dizer que as forças finais a serem aplicadas em cada andar, podem ser determinadas multiplicando-se os valores iniciais das forças $\mathrm{H}_{\mathrm{i}}$ por uma constante.

Esta constante, que pode ser maior ou menor do que a unidade, uma vez que pode ser de majoração ou de minoração, depende da localização do pórtico em relação ao centro elástico da estrutura e no caso do edifício em estudo pode ser representada pela razão $\left(F_{i}+H_{i}\right) / H_{i}$.

As ações aplicadas a cada face são:

a-Na face maior

$$
\begin{aligned}
& H_{i}=492,3 \mathrm{kN} \\
& M_{T}^{\circ}=6 \times 6,75 \mathrm{H}_{\mathrm{i}}=19.938,15 \mathrm{kN} \cdot \mathrm{m}
\end{aligned}
$$

\section{b-Na Face Menor}

$$
\begin{aligned}
& H_{i}=253,7 \mathrm{kN} \\
& M_{T}=4 \times 3 \times \mathrm{H}=3.044,4 \mathrm{kN} . \mathrm{m}
\end{aligned}
$$


As ações aplicadas na face maior são mais intensas que as aplicadas na face menor e considerando que os pórticos que sustentam a face maior possuem um número menor de colunas, com menor distância entre elas, concluiu-se não ser necessário realizar as duas simulações de carregamento. A incidência na face maior conduzirá a solicitações maiores, portanto críticas.

Aplicando inicialmente as forças $H_{i}$, determinadas no item 4.3, nos pórticos da face maior e da face menor, verificou-se que os deslocamentos nos pórticos das filas eram muito menores que os obtidos nos pórticos dos eixos, que inclusive estavam acima dos recomendados. Portanto, os perfis pré-escolhidos para as colunas devem ser substiuídos.

Nesta situação pode ser mais indicado a composição de novas seções, pois a adoção pura e simples de um outro perfil da mesma série, pode atender às condições de resistência, mas não à de relação entre as inércias.

Outro motivo que recomenda a composição de uma seção é a economia que pode ser conseguida, explorando-se ao máximo a esbeltez limite das chapas que comporão esta nova seção, lembrando ainda que os perfis das séries padronizadas não são encontrados estocados no mercado, necessitando portanto de encomenda prévia.

Ora, encomendar um perfil padronizado ou não, em nada ou em quase nada encarece sua fabricação.

Após substituir os perfis das colunas, de modo a atender as recomendações da norma quanto aos deslocamentos horizontais, obtém-se os seguintes deslocamentos no topo dos pórticos:

$$
\begin{aligned}
& \delta_{1}=\delta_{6}=8,87 \mathrm{~cm} \\
& \delta_{2}=\delta_{3}=\delta_{4}=\delta_{5}=7,59 \mathrm{~cm} \\
& \delta_{A}=\delta_{B}=\delta_{C}=\delta_{D}=5,67 \mathrm{~cm}
\end{aligned}
$$

e, a rigidez relativa de cada pórtico que será:

$$
\begin{aligned}
& R_{1}=R_{6}=\Sigma H_{1} / \delta_{1}=55,51 \mathrm{kN} / \mathrm{cm} \\
& R_{2}=R_{3}=R_{4}=R_{5}=64,85 \mathrm{kN} / \mathrm{cm} \\
& R_{A}=R_{B}=R_{C}=R_{D}=44,72 \mathrm{kN} / \mathrm{cm}
\end{aligned}
$$


Nos pórticos do eixo 1 até o eixo 6, embora as açōes aplicadas tivessem a mesma intensidade, os deslocamentos obtidos foram diferentes, uma vez que a área e o momento de inércia finais de algumas barras resultaram diferentes, conduzindo portanto a rigidez diferentes para estes pórticos.

Nos pórticos das filas $A$ até a fila $D$ considerou-se que as barras tivessem a mesma rigidez, embora nas vigas das filas internas ( $B$ e C ) pudesse ser utilizada uma área de contribuição da laje um pouco maior que a considerada.

Este procedimento é justificado pela hipótese já assumida de que a laje exerce papel de diafragma, compatibilizando os deslocamentos nesta direção e como os perfis metálicos neste plano possuem as mesmas propriedades, admitiu-se que conduziriam às mesmas rigidez.

Portanto, na face maior, a ação global do vento deve ser redividida, uma vez que os pórticos possuem rigidez diferenciadas.

Neste caso, o deslocamento médio, comum a todos os pórticos, uma vez que estão solidarizados pela laje, pode ser determinado como:

$$
\delta_{\text {médio }}=\frac{\sum \mathrm{H}_{\mathrm{i}}}{\sum \mathrm{R}_{\mathrm{i}}}=7,97 \mathrm{~cm}
$$

e os novos valores das forças $H_{i}$ em cada pórtico serão obtidos fazendo-se:

$$
H_{i}=R \delta_{\text {médio }}
$$

Portanto: $\quad \mathrm{H}_{1}=\mathrm{H}_{6}=442,63 \mathrm{kN}$

$$
\mathrm{H}_{2}=\mathrm{H}_{3}=\mathrm{H}_{4}=\mathrm{H}_{5}=517,13 \mathrm{kN}
$$

As forças $\mathrm{F}_{\mathrm{i}}$, despertadas pelo momento de torção, podem agora ser determinadas, uma vez que se conhece a rigidez de cada pórtico, obtendose:

$$
\begin{aligned}
& F_{1}=-F_{6}=249,57 \mathrm{kN} \\
& F_{2}=-F_{5}=174,94 \mathrm{kN} \\
& F_{3}=-F_{4}=58,31 \mathrm{kN} \\
& F_{A}=-F_{B}=107,22 \mathrm{kN} \\
& F_{C}=-F_{D}=35,74 \mathrm{kN}
\end{aligned}
$$


Encontra-se como resultante, a ser aplicada em cada pórtico:

$$
\begin{aligned}
& H_{F 1}=H_{1}+F_{1}=692,2 \mathrm{kN} \\
& H_{F 2}=692,1 \mathrm{kN} \\
& H_{F 3}=575,44 \mathrm{kN} \\
& H_{F 4}=458,82 \mathrm{kN} \\
& H_{F 5}=342,19 \mathrm{kN} \\
& H_{F 6}=267,56 \mathrm{kN} \\
& H_{F A}=107,22 \mathrm{kN} \\
& H_{F B}=35,74 \mathrm{kN} \\
& H_{F C}=-35,74 \mathrm{kN} \\
& H_{F D}=-107,22 \mathrm{kN}
\end{aligned}
$$

Estas forças representam os somatórios das ações horizontais aplicadas em cada pórtico. Dividindo-as proporcionalmente às ações iniciais aplicadas em cada andar, obtém-se o valor final a ser aplicado em cada um, simulando assim a inclusão do momento de torção ao efeito de arrasto do vento. Com estas ações finais é possivel determinar os deslocamentos em cada andar.

Alternativamente, os deslocamentos no topo podem ser determinados, com suficiente precisão, bastando tão somente dividir os somatórios das açōes horizontais aplicados em cada pórtico pela respectiva rigidez relativa de cada pórtico, ou seja, segundo a seguinte expressão:

$$
\delta_{\mathrm{T}}=\frac{\mathrm{F}_{\mathrm{i}}+\mathrm{H}_{\mathrm{i}}}{\mathrm{R}_{\mathrm{i}}}
$$

obtendo-se, com h $=70 \mathrm{~m}$ que é a altura do edifício:

$$
\begin{array}{rlrl}
\delta_{\mathrm{T}_{1}}=12,47 \mathrm{~cm} & & =\mathrm{h} / 560 \\
\delta_{\mathrm{T} 2} & =10,67 \mathrm{~cm} & & =\mathrm{h} / 650 \\
\delta_{\mathrm{T} 3} & =8,87 \mathrm{~cm} & & =\mathrm{h} / 790 \\
\delta_{\mathrm{T} 4} & =8,87 \mathrm{~cm} & & =\mathrm{h} / 790 \\
\delta_{\mathrm{T} 5} & =5,28 \mathrm{~cm} & & =\mathrm{h} / 1327 \\
\delta_{\mathrm{T} 6} & =4,82 \mathrm{~cm} & & =\mathrm{h} / 1450 \\
\delta_{\mathrm{TA}} & =-\delta_{\mathrm{TD}}=2,40 \mathrm{~cm} & & =\mathrm{h} / 2900 \\
\delta_{\mathrm{TB} 1} & =-\delta_{\mathrm{TC}}=0,80 \mathrm{~cm} & & =\mathrm{h} / 8760
\end{array}
$$


Com pode ser observado, os deslocamentos calculados estão dentro dos limites mínimos preconizados pela NBR-8800, que é de $h / 500$.

Cabe observar que os valores dos deslocamentos do topo, calculados manualmente, ou via computador não apresentaram diferenças superiores a $1 \%$. Estes deslocamentos, assim como as deformações, refletem o comportamento de serviço ou de utilização da estrutura, uma vez que foram calculados com os valores nominais das ações.

As solicitações nas barras, no entanto, devem refletir o comportamento último da estrutura e devem portanto serem calculadas com os valores de cálculo destas solicitações e a combinação utilizada, que foi considerada como a crítica, que foi determinada pela seguinte expressão:

$$
C_{p}=1,4 P_{p}+1,5 S_{c}+1,4 w
$$

onde: $P_{p}=$ Ações permanentes

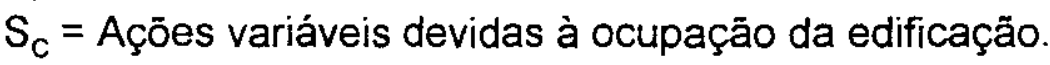

$\mathrm{w}=$ Ação devida à incidência do vento na face maior.

Evidentemente, a verificação das barras pode conduzir a algumas surpresas.

Algumas barras podem estar sub ou superestimadas exigindo sua substituição, que deve ser feita levando em conta também a deslocabilidade da estrutura, ou seja, não pode ser esquecido o estado limite de deformação.

A substituição pura e simples de uma, ou de algumas barras, costuma provocar uma redistribuição de solicitações que pode inclusive compromoter algumas barras que antes das substituições não estavam comprometidas.

Apenas como ilustração, apresentam-se as solicitações obtidas nas seis iterações realizadas na estrutura, até que a mesma estivesse com igual comprometimento em suas barras, que permitem observar as variaçōes que ocorreram nas solicitações ao longo do processo.

Evidentemente', cada iteração representa uma fase da otimização estrutural, onde foram trocadas as barras que estivessem fora do indice de aproveitamento adotado, que era da ordem de 95 a 105\% da capacidade do perfil. 


\section{PRIMEIRA ITERAÇĀO}

\begin{tabular}{|c|c|c|c|c|c|c|c|c|}
\hline \multirow[t]{2}{*}{ LANCE } & \multirow[t]{2}{*}{ FILA } & \multirow[t]{2}{*}{ ESFORÇO } & \multicolumn{6}{|c|}{ EIXOS } \\
\hline & & & 1 & 2 & 3 & 4 & 5 & 6 \\
\hline \multirow{6}{*}{1} & \multirow{3}{*}{$A$} & $\mathrm{~N}$ & 4.150 & 7.375 & 7.186 & 4.941 & 4.646 & 1.960 \\
\hline & & $M_{x}$ & 105.328 & 94.556 & 80.303 & 67.357 & 81.803 & 99.730 \\
\hline & & $M_{v}$ & 17.213 & 22.609 & 22.519 & 22.618 & 22.707 & 22.512 \\
\hline & \multirow{3}{*}{ B } & $N$ & 5.406 & 9.333 & 9.141 & 6.519 & 6.166 & 2.493 \\
\hline & & $M_{x}$ & 111.091 & 92.350 & 76.409 & 87.808 & 103.808 & 116.989 \\
\hline & & $M_{v}$ & 11.449 & 17.610 & 17.592 & 17.790 & 17.911 & 19.692 \\
\hline \multirow{6}{*}{2} & \multirow{3}{*}{$A$} & $N$ & 3.288 & 5.794 & 5.673 & 4.002 & 3.773 & 1.596 \\
\hline & & $M_{x}$ & 31.082 & 33.748 & 30.810 & 5.117 & 8.561 & 18.295 \\
\hline & & $M_{v}$ & 2.594 & 15.206 & 15.575 & 15.609 & 16.331 & 15.333 \\
\hline & \multirow{3}{*}{ B } & $\mathrm{N}$ & 3880 & 7011 & 6947 & 5556 & 5330 & 2441 \\
\hline & & $M_{x}$ & 49.172 & 35.052 & 27.727 & 56.679 & 60.470 & 61.210 \\
\hline & & $M_{v}$ & 2.720 & 11.503 & 12.196 & 12.250 & 13.218 & 16.691 \\
\hline \multirow{6}{*}{3} & \multirow{3}{*}{ A } & $\mathrm{N}$ & 2.357 & 4.196 & 4.120 & 3.088 & 2.941 & 1.278 \\
\hline & & $M_{x}$ & 29.681 & 32.956 & 29.716 & 3.604 & 6.841 & 16.592 \\
\hline & & $M_{v}$ & 7.56 & 11.283 & 12.259 & 12.260 & 13.331 & 13.886 \\
\hline & \multirow{3}{*}{ B } & $\mathrm{N}$ & 2.514 & 4.078 & 4.891 & 4.453 & 4.344 & 2.194 \\
\hline & & $M_{x}$ & 38.024 & 25.727 & 19.547 & 44.095 & 50.226 & 50.289 \\
\hline & & $M_{v}$ & 4.493 & 8.090 & 9.609 & 9.609 & 11.205 & 15.760 \\
\hline \multirow{6}{*}{4} & \multirow{3}{*}{ A } & $\mathrm{N}$ & 1.465 & 2.678 & 2.642 & 2.116 & 2.046 & 904 \\
\hline & & $M_{x}$ & 22.260 & 26.394 & 24.172 & 2.911 & 1.225 & 9.130 \\
\hline & & $M_{V}$ & 931 & 7.327 & 8.377 & 8.320 & 9.364 & 11.446 \\
\hline & \multirow{3}{*}{$B$} & $\mathrm{~N}$ & 1.523 & 3.040 & 3.068 & 3.111 & 3.085 & 1.835 \\
\hline & & $M_{x}$ & 21.016 & 11.481 & 7.730 & 30.857 & 34.613 & 32.569 \\
\hline & & $M_{v}$ & 7.395 & 4.994 & 6.588 & 6.500 & 8.320 & 14.360 \\
\hline \multirow{6}{*}{5} & \multirow{3}{*}{$A$} & $\mathrm{~N}$ & 654 & 1.252 & 1.234 & 1.063 & 1.051 & 465 \\
\hline & & $M_{x}$ & 16.297 & 20.400 & 18.950 & 3.621 & 2.131 & 4.992 \\
\hline & & $M_{v}$ & 1.066 & 3,685 & 4.156 & 4,120 & 4.536 & 7.144 \\
\hline & \multirow{3}{*}{$B$} & $\mathrm{~N}$ & 697 & 1.412 & 1.422 & 1.587 & 1.611 & 862 \\
\hline & & $M_{x}$ & 6.935 & 2.500 & 835 & 19.139 & 21.044 & 18.287 \\
\hline & & $M_{v}$ & 8.830 & 2.571 & 3.273 & 3.216 & 3.873 & 8.594 \\
\hline
\end{tabular}


SEGUNDA ITERAÇÃO

\begin{tabular}{|c|c|c|c|c|c|c|c|c|}
\hline \multirow[t]{2}{*}{ LANCE } & \multirow[t]{2}{*}{ FILA } & \multirow[t]{2}{*}{ ESFORÇO } & \multicolumn{6}{|c|}{ EIXOS } \\
\hline & & & 1 & 2 & 3 & 4 & 5 & 6 \\
\hline \multirow{6}{*}{1} & \multirow{3}{*}{$A$} & $\mathrm{~N}$ & 4.054 & 6.980 & 7.021 & 5.095 & 5.045 & 2.753 \\
\hline & & $M_{x}$ & 103.199 & 101.523 & 101.543 & 87.690 & 87.670 & 95.723 \\
\hline & & $M_{v}$ & 20.227 & 24.732 & 24.990 & 25.142 & 25.262 & 26.750 \\
\hline & \multirow{3}{*}{$B$} & $\mathrm{~N}$ & 5.357 & 8.881 & 8.960 & 6.668 & 6.600 & 3.505 \\
\hline & & $M_{x}$ & 102.222 & 94.906 & 94.922 & 107.970 & 107.454 & 109.442 \\
\hline & & $M_{v}$ & 18.434 & 24.523 & 24.927 & 25.204 & 25.471 & 28.543 \\
\hline \multirow{6}{*}{2} & \multirow{3}{*}{$A$} & $\mathrm{~N}$ & 3.236 & 5.530 & 5.572 & 4.093 & 4.043 & 2.202 \\
\hline & & $M_{x}$ & 27.687 & 31.590 & 31.621 & 8.298 & 8.266 & 13.862 \\
\hline & & $M_{v}$ & 603 & 10.222 & 10.700 & 10.810 & 11.280 & 12.483 \\
\hline & \multirow{3}{*}{$B$} & $N$ & 4.075 & 6.820 & 6.894 & 5.575 & 5.513 & 3.000 \\
\hline & & $M_{x}$ & 31.974 & 26.520 & 26.524 & 48.073 & 98.070 & 44.010 \\
\hline & & $M_{v}$ & 3.945 & 9.948 & 10.672 & 10.840 & 11.533 & 15.824 \\
\hline \multirow{6}{*}{3} & \multirow{3}{*}{$A$} & $N$ & 2.344 & 4.032 & 4.065 & 3.146 & 3.107 & 1.706 \\
\hline & & $M_{x}$ & 19.365 & 28.253 & 28.233 & 2.120 & 2.139 & 3.626 \\
\hline & & $M_{v}$ & 2.028 & 7.770 & 8.619 & 8.691 & 9.500 & 11.691 \\
\hline & \multirow{3}{*}{$B$} & $\mathrm{~N}$ & 2.831 & 4.830 & 4.893 & 4.421 & 9.375 & 2.40 \\
\hline & & $M_{x}$ & 22.408 & 16.458 & 16.364 & 40.816 & 40.910 & 38.818 \\
\hline & & $M_{v}$ & 5.533 & 7.324 & 8.600 & 8.710 & 9.947 & 15.196 \\
\hline \multirow{6}{*}{4} & \multirow{3}{*}{$A$} & $\mathrm{~N}$ & 1.493 & 2.585 & 2.600 & 2.15 & 2.130 & 1.156 \\
\hline & & $M_{x}$ & 18.085 & 23.204 & 22.950 & 3.117 & 2.421 & 2.326 \\
\hline & & $M_{v}$ & 3.330 & 4.891 & 5.905 & 5.943 & 6.899 & 10.180 \\
\hline & \multirow{3}{*}{$B$} & $\mathrm{~N}$ & 1.700 & 3.073 & 3.011 & 3.047 & 3.026 & 1.725 \\
\hline & & $M_{x}$ & 12.244 & 5.647 & 5.970 & 28.790 & 28.694 & 25.525 \\
\hline & & $M_{v}$ & 6.786 & 4.370 & 5.896 & 5.953 & 7.420 & 13.625 \\
\hline \multirow{6}{*}{5} & \multirow{3}{*}{$A$} & $\mathrm{~N}$ & 685 & 1.214 & 1.216 & 1.085 & 1.083 & 567 \\
\hline & & $M_{x}$ & 14.633 & 18.680 & 18.808 & 5.830 & 5.962 & 1.170 \\
\hline & & $M_{V}$ & 3.434 & 2.391 & 2.930 & 2.998 & 3.457 & 7.274 \\
\hline & \multirow{3}{*}{$B$} & $\mathrm{~N}$ & 745 & 1.469 & 1.470 & 1.530 & 1.521 & 910 \\
\hline & & $M_{x}$ & 6.961 & 1.701 & 1.600 & 20.567 & 20.471 & 16.133 \\
\hline & & $M_{v}$ & 6.175 & 2.110 & 2.927 & 2.950 & 3.738 & 9.687 \\
\hline
\end{tabular}




\section{TERCEIRA ITERAÇÃO}

\begin{tabular}{|c|c|c|c|c|c|c|c|c|}
\hline \multirow[t]{2}{*}{ LANCE } & \multirow[t]{2}{*}{ FILA } & \multirow[t]{2}{*}{ ESFORÇO } & \multicolumn{6}{|c|}{ EIXOS } \\
\hline & & & 1 & 2 & 3 & 4 & 5 & 6 \\
\hline \multirow{6}{*}{1} & \multirow{3}{*}{ A } & $\mathrm{N}$ & 4.353 & 7.351 & 7.091 & 5.030 & 4.692 & 2.428 \\
\hline & & $M_{x}$ & 97.171 & 89.240 & 80.679 & 67.311 & 66.230 & 70.361 \\
\hline & & $M_{v}$ & 7.328 & 7.760 & 7.807 & 7.903 & 7.956 & 8.012 \\
\hline & \multirow{3}{*}{ B } & $\mathrm{N}$ & 5.370 & 9.622 & 9.269 & 6.361 & 5.889 & 2.761 \\
\hline & & $M_{x}$ & 99.710 & 95.380 & 84.790 & 96.832 & 97.489 & 96.667 \\
\hline & & $M_{v}$ & 11.964 & 11.237 & 11.371 & 11.575 & 11.714 & 13.842 \\
\hline \multirow{6}{*}{2} & \multirow{3}{*}{$A$} & $\mathrm{~N}$ & 3.482 & 5.809 & 5.623 & 4.045 & 3.780 & 1.935 \\
\hline & & $M_{x}$ & 35.176 & 38.045 & 32.451 & 8.046 & 13.644 & 23.414 \\
\hline & & $M_{V}$ & 2.624 & 6.114 & 6.399 & 6.438 & 6.934 & 10.571 \\
\hline & \multirow{3}{*}{$B$} & $\mathrm{~N}$ & 4.510 & 7.318 & 7.125 & 5.348 & 5.037 & 2.540 \\
\hline & & $M_{x}$ & 50.623 & 41.110 & 29.695 & 52.924 & 64.341 & 63.592 \\
\hline & & $M_{y}$ & 2.769 & 12.112 & 12.626 & 12.688 & 13.364 & 16.795 \\
\hline \multirow{6}{*}{3} & \multirow{3}{*}{ A } & $\mathrm{N}$ & 2.519 & 4.211 & 4.101 & 3.112 & 2.940 & 1.518 \\
\hline & & $M_{x}$ & 31.590 & 35.026 & 30.292 & 3.948 & 8.676 & 15.843 \\
\hline & & $M_{v}$ & 834 & 12.246 & 12.876 & 12.915 & 13.655 & 13.929 \\
\hline & \multirow{3}{*}{$B$} & $\mathrm{~N}$ & 2.960 & 5.055 & 5.003 & 4.313 & 4.168 & 2.289 \\
\hline & & $M_{x}$ & 39.976 & 30.757 & 21.371 & 46.547 & 55.931 & 53.917 \\
\hline & & $M_{v}$ & 4.280 & 8.914 & 9.912 & 9.970 & 11.053 & 15.609 \\
\hline \multirow{6}{*}{4} & \multirow{3}{*}{$A$} & $N$ & 1.588 & 2.685 & 2.631 & 2.126 & 2.038 & 1.057 \\
\hline & & $M_{x}$ & 24.291 & 28.263 & 24.959 & -5.366 & -3.495 & 8.282 \\
\hline & & $M_{v}$ & 1.224 & 8.061 & 8.864 & 8.867 & 9.695 & 11.698 \\
\hline & \multirow{3}{*}{$B$} & $N$ & 1.701 & 3.095 & 3.111 & 3.046 & 3.010 & 1.740 \\
\hline & & $M_{x}$ & 22.665 & 14.888 & 9.007 & 33.498 & 39.364 & 36.096 \\
\hline & & $M_{v}$ & 5.728 & 5.602 & 6.837 & 6.033 & 8.086 & 13.803 \\
\hline \multirow{6}{*}{5} & \multirow{3}{*}{$A$} & $\mathrm{~N}$ & 798 & 1.409 & 1.389 & 1.222 & 1.198 & 610 \\
\hline & & $M_{x}$ & 19.539 & 24.498 & 22.246 & -6.881 & -3.702 & 2.985 \\
\hline & & $M_{v_{2}}$ & 3.214 & 3.864 & 4.509 & 4.488 & 5.074 & 8.997 \\
\hline & \multirow{3}{*}{$B$} & $\mathrm{~N}$ & 815 & 1.634 & 1.658 & 1.803 & 1.821 & 1.049 \\
\hline & & $M_{x}$ & 6.332 & 1.369 & 2.719 & 23.688 & 26.730 & 22.103 \\
\hline & & $M_{v}$ & 7.307 & 2.490 & 3.486 & 3.450 & 4.400 & 11.764 \\
\hline
\end{tabular}


QUARTA ITERAÇÃO

\begin{tabular}{|c|c|c|c|c|c|c|c|c|}
\hline \multirow[t]{2}{*}{ LANCE } & \multirow[t]{2}{*}{ FILA } & \multirow[t]{2}{*}{ ESFORÇO } & \multicolumn{6}{|c|}{ ElXOS } \\
\hline & & & 1 & 2 & 3 & 4 & 5 & 6 \\
\hline \multirow{6}{*}{1} & \multirow{3}{*}{$A$} & $\mathrm{~N}$ & 4.067 & 6.994 & 7.010 & 5.106 & 5.048 & 2.723 \\
\hline & & $M_{x}$ & 86.695 & 89.723 & 95.037 & 81.113 & 75.870 & 79.223 \\
\hline & & $M_{v}$ & 6.269 & 10.767 & 11.034 & 11.185 & 11.305 & 12.854 \\
\hline & \multirow{3}{*}{ B } & $\mathrm{N}$ & 5.301 & 8.899 & 8.982 & 6.643 & 6.613 & 3.529 \\
\hline & & $M_{x}$ & 96.049 & 93.211 & 98.230 & 110.912 & 105.759 & 103.208 \\
\hline & & $M_{y}$ & 19.450 & 25.550 & 25.970 & 26.248 & 26.510 & 29.673 \\
\hline \multirow{6}{*}{2} & \multirow{3}{*}{$A$} & $\mathrm{~N}$ & 3.237 & 5.542 & 5.564 & 4.098 & 4.052 & 2.183 \\
\hline & & $M_{x}$ & 27.237 & 31.459 & 32.079 & 8.392 & 7.854 & 13.260 \\
\hline & & $M_{v}$ & 570 & 10.194 & 10.642 & 10.753 & 11.194 & 12.413 \\
\hline & \multirow{3}{*}{$B$} & $\mathrm{~N}$ & 4.010 & 6.837 & 6.924 & 5.544 & 5.527 & 3.035 \\
\hline & & $M_{x}$ & 31.727 & 26.256 & 26.822 & 48.855 & 48.171 & 43.890 \\
\hline & & $M_{y}$ & 2.238 & 9.294 & 10.010 & 10.240 & 10.851 & 11.454 \\
\hline \multirow{6}{*}{3} & \multirow{3}{*}{$A$} & $\mathrm{~N}$ & 2.351 & 4.041 & 4.061 & 3.149 & 3.117 & 1.686 \\
\hline & & $M_{x}$ & 20.246 & 28.186 & 28.208 & 2.113 & 2.190 & 6.908 \\
\hline & & $M_{V}$ & 1.874 & 1.857 & 1.579 & 8.638 & 9.365 & 11.556 \\
\hline & \multirow{3}{*}{$B$} & $N$ & 2.776 & 4.852 & 4.910 & 4.400 & 4.381 & 2.468 \\
\hline & & $M_{x}$ & 21.471 & 16.308 & 16.617 & 40.967 & 40.455 & 34.828 \\
\hline & & $M_{v}$ & 5.305 & 7.466 & 8.564 & 8.653 & 9.757 & 14.987 \\
\hline \multirow{6}{*}{4} & \multirow{3}{*}{$A$} & $\mathrm{~N}$ & 1.485 & 2.587 & 2.600 & 2.153 & 2.143 & 1.154 \\
\hline & & $M_{x}$ & 17.863 & 22.676 & 22.867 & 2.865 & 2.721 & 2.240 \\
\hline & & $M_{y}$ & 3.240 & 5.082 & 5.868 & 5.909 & 6.666 & 10.027 \\
\hline & \multirow{3}{*}{$B$} & $\mathrm{~N}$ & 1.722 & 3.104 & 3.117 & 3.036 & 3.013 & 1.712 \\
\hline & & $M_{x}$ & 10.916 & 5.351 & 5.583 & 28.820 & 27.933 & 23.573 \\
\hline & & $M_{v}$ & 6.631 & 4.670 & 5.859 & 5.919 & 7.078 & 13.448 \\
\hline \multirow{6}{*}{5} & \multirow{3}{*}{$A$} & $\mathrm{~N}$ & 676 & 1.215 & 1.216 & 1.083 & 1.086 & 572 \\
\hline & & $M_{x}$ & 14.079 & 18.691 & 18.780 & 5.856 & 5.946 & 1.482 \\
\hline & & $M_{k}$ & 3.480 & 2.535 & 2.945 & 2.977 & 3.387 & 7.316 \\
\hline & \multirow{3}{*}{$B$} & $\mathrm{~N}$ & 776 & 1.477 & 1.468 & 1.523 & 1.519 & 851 \\
\hline & & $M_{x}$ & 6.042 & 1.535 & 1.578 & 20.590 & 20.634 & 15.985 \\
\hline & & $M_{V}$ & 8.242 & 2.309 & 2.938 & 2.984 & 3.612 & 10.078 \\
\hline
\end{tabular}


QUINTA ITERAÇÃO

\begin{tabular}{|c|c|c|c|c|c|c|c|c|}
\hline \multirow[t]{2}{*}{ LANCE } & \multirow[t]{2}{*}{ FILA } & \multirow[t]{2}{*}{ ESFORÇO } & \multicolumn{6}{|c|}{ EIXOS } \\
\hline & & & 1 & 2 & 3 & 4 & 5 & 6 \\
\hline \multirow{6}{*}{1} & \multirow{3}{*}{ A } & $\mathrm{N}$ & 4.445 & 7.015 & 6.840 & 4.670 & 4.400 & 2.070 \\
\hline & & $M_{x}$ & 89.575 & 94.790 & 81.110 & 53.395 & 66.975 & 73.050 \\
\hline & & $M_{x}$ & -5.650 & 7.360 & 7.165 & 7.015 & 6.905 & 12.150 \\
\hline & \multirow{3}{*}{$B$} & $\mathrm{~N}$ & 5.755 & 8.835 & 8.655 & 6.120 & 5.865 & 2.670 \\
\hline & & $\mathbf{M}_{\mathbf{x}}$ & 92.465 & 85.730 & 68.825 & 97.976 & 114.870 & 108.815 \\
\hline & & $M_{V}$ & 9.400 & 2.731 & 2.480 & 2.060 & 2.025 & 11.935 \\
\hline \multirow{6}{*}{2} & \multirow{3}{*}{$A$} & $\mathrm{~N}$ & 3.655 & 5.830 & 5.699 & 3.975 & 3.750 & 1.790 \\
\hline & & $M_{x}$ & 36.010 & 39.720 & 34.990 & 11.670 & 16.400 & 22.205 \\
\hline & & $M_{v}$ & -4.035 & 4.015 & 4.490 & 4.600 & 5.075 & 9.060 \\
\hline & \multirow{3}{*}{ B } & $\mathrm{N}$ & 4.540 & 7.100 & 7.010 & 5.465 & 5.240 & 2.540 \\
\hline & & $M_{x}$ & 47.335 & 41.660 & 32.825 & 54.375 & 63.210 & 59.300 \\
\hline & & $M_{v}$ & 9.050 & 710 & 1.435 & 1.600 & 2.320 & 10.725 \\
\hline \multirow{6}{*}{3} & \multirow{3}{*}{ A } & $N$ & 2.600 & 4.220 & 4.195 & 3.075 & 2.930 & 1.465 \\
\hline & & $M_{X}$ & 28.535 & 34.395 & 30.800 & 4.690 & 8.280 & 14.300 \\
\hline & & $M_{V}$ & 4.820 & 2.785 & 3.620 & 3.695 & 4.515 & 8.900 \\
\hline & \multirow{3}{*}{ B } & $\mathrm{N}$ & 3.070 & 4.935 & 4.935 & 4.385 & 4.270 & 2.210 \\
\hline & & $M_{x}$ & 34.365 & 27.970 & 21.195 & 45.650 & 52.420 & 46.515 \\
\hline & & $\mathbf{M}_{v}$ & 9.685 & 128 & 1.165 & 1.275 & 2.530 & 11.0505 \\
\hline \multirow{6}{*}{4} & \multirow{3}{*}{ A } & $N$ & 1.615 & 2.710 & 2.645 & 2.120 & 2.045 & 1.035 \\
\hline & & $M_{x}$ & 22.270 & 27.090 & 24.675 & 1.730 & 1.210 & 6.382 \\
\hline & & $M_{v}$ & 5.310 & 1.490 & 2.490 & 2.525 & 3.495 & 8.200 \\
\hline & \multirow{3}{*}{$B$} & $N$ & 1.795 & 3.095 & 3.120 & 3.045 & 3.000 & 1.680 \\
\hline & & $M_{x}$ & 19.925 & 12.452 & 8.390 & 31.685 & 35.740 & 33.185 \\
\hline & & $M_{v}$ & 9.730 & 700 & 810 & 865 & 2.360 & 10.700 \\
\hline \multirow{6}{*}{5} & \multirow{3}{*}{$A$} & $N$ & 800 & 1.400 & 1.390 & 1.230 & 1.210 & 610 \\
\hline & & $\mathbf{M}_{\mathbf{x}}$ & 18.460 & 23.225 & 21.685 & 6.515 & 4.975 & 1.925 \\
\hline & & $M_{k}$ & 5.150 & 640 & 1.235 & 1.250 & 1.835 & 6.775 \\
\hline & \multirow{3}{*}{$B$} & $\mathrm{~N}$ & 855 & 1.690 & 1.700 & 1.775 & 1.770 & 1.000 \\
\hline & & $M_{x}$ & 7.250 & 655 & 1.595 & 23.770 & 26.010 & 21.2020 \\
\hline & & $M_{v}$ & 9.045 & 620 & 400 & 430 & 1.390 & 9.585 \\
\hline
\end{tabular}


SEXTA ITERAÇÃO

\begin{tabular}{|c|c|c|c|c|c|c|c|c|}
\hline \multirow[t]{2}{*}{ LANCE } & \multirow[t]{2}{*}{ FILA } & \multirow[t]{2}{*}{ ESFORÇO } & \multicolumn{6}{|c|}{ EIXOS } \\
\hline & & & 1 & 2 & 3 & 4 & 5 & 6 \\
\hline \multirow{6}{*}{1} & \multirow{3}{*}{$A$} & $N$ & 4.380 & 7.054 & 6.850 & 4.656 & 4.354 & 2.084 \\
\hline & & $M_{x}$ & 94.390 & 91.462 & 81.947 & 54.226 & 69.631 & 77.888 \\
\hline & & $M_{x}$ & 5.621 & 2.754 & 2.716 & 2.647 & 2.675 & 7.122 \\
\hline & \multirow{3}{*}{$B$} & $\mathrm{~N}$ & 5.755 & 8.869 & 8.670 & 6.168 & 5.820 & 2.662 \\
\hline & & $M_{x}$ & 96.558 & 89.056 & 69.860 & 99.010 & 118.200 & 112.915 \\
\hline & & $M_{y}$ & 9.391 & 2.826 & 2.591 & 2.343 & 2.068 & 12.000 \\
\hline \multirow{6}{*}{2} & \multirow{3}{*}{$A$} & $N$ & 3.640 & 5.864 & 5.707 & 3.957 & 3.711 & 1.796 \\
\hline & & $M_{x}$ & 36.034 & 40.608 & 35.280 & 11.960 & 17.291 & 22.216 \\
\hline & & $M_{v}$ & 3.932 & 4.199 & 4.676 & 4.787 & 5.260 & 9.158 \\
\hline & \multirow{3}{*}{ B } & $\mathrm{N}$ & 4.546 & 7.113 & 7.015 & 5.455 & 5.219 & 2.527 \\
\hline & & $M_{x}$ & 47.243 & 43.903 & 33.365 & 54.916 & 64.955 & 59.280 \\
\hline & & $M_{V}$ & 9.017 & 770 & 1.492 & 1.660 & 2.381 & 10.758 \\
\hline \multirow{6}{*}{3} & \multirow{3}{*}{$A$} & $N$ & 2.585 & 4.241 & 9.149 & 3.062 & 2.899 & 1.462 \\
\hline & & $M_{x}$ & 27.850 & 30.160 & 31.018 & 4.903 & 9.015 & 13.615 \\
\hline & & $M_{v}$ & 4.734 & 2.934 & 3.771 & 3.844 & 4.664 & 8.986 \\
\hline & \multirow{3}{*}{ B } & $\mathrm{N}$ & 3.058 & 4.932 & 4.937 & 4.377 & 4.275 & 2.212 \\
\hline & & $M_{x}$ & 33.856 & 29.445 & 21.609 & 46.050 & 53.896 & 44.713 \\
\hline & & $M_{v}$ & 9.658 & -83 & 1.214 & 1.323 & 2.578 & 11.073 \\
\hline \multirow{6}{*}{4} & \multirow{3}{*}{$A$} & $\mathrm{~N}$ & 1.613 & 2.688 & 2.644 & 2.112 & 2.028 & 1.036 \\
\hline & & $M_{x}$ & 22.251 & 27.967 & 24.820 & -1.607 & 2.224 & 6.364 \\
\hline & & $M_{v}$ & 5.249 & 1.589 & 2.587 & 2.626 & 3.598 & 8.262 \\
\hline & \multirow{3}{*}{ B } & $\mathrm{N}$ & 2.324 & 4.099 & 4.158 & 4.081 & 4.031 & 2.211 \\
\hline & & $M_{x}$ & 19.844 & 13.428 & 8.638 & 31.932 & 36.460 & 33.105 \\
\hline & & $M_{v}$ & 9.657 & -83 & 1.088 & 1.228 & 2.579 & 11.074 \\
\hline \multirow{6}{*}{5} & \multirow{3}{*}{$A$} & $\mathrm{~N}$ & 799 & 1.320 & 1.383 & 626 & 1.132 & 607 \\
\hline & & $M_{x}$ & 18.438 & 25.560 & 21.778 & 6.418 & 3.085 & 1.905 \\
\hline & & $M_{\mathrm{v}}$ & 5.118 & 690 & 1.200 & 1.300 & 1.883 & 6.807 \\
\hline & \multirow{3}{*}{$B$} & $\mathrm{~N}$ & 1.309 & 2.475 & 2.583 & 2.653 & 2.550 & 1.484 \\
\hline & & $M_{x}$ & 7.202 & 2.547 & 1.458 & 23.903 & 24.720 & 20.968 \\
\hline & & $M_{v}$ & 9.709 & 667 & 840 & 897 & 1.390 & 10.713 \\
\hline
\end{tabular}


De posse das solicitações e das seções dos perfis, é possivel fazer a verificação final, como preconiza a NBR-8800.

1-Primeiro Lance - Pavimento Térreo.

Perfil final: CVS $900 \times 654$

Seção: 2 ch. $45 \times 700$

1 ch. $25 \times 810$

Propriedades Geométricas

$$
\begin{aligned}
& \mathrm{I}_{\mathrm{x}}=1.263 .144 \mathrm{~cm}^{4} \\
& \mathrm{I}_{\mathrm{y}}=257.355 \mathrm{~cm}^{4} \\
& Z_{x}=26.833 \mathrm{~cm}^{3} \\
& Z_{y}=11.088 \mathrm{~cm}^{3} \\
& A=\quad 832,5 \mathrm{~cm}^{2} \\
& i_{x}=38,95 \mathrm{~cm} \\
& \mathrm{i}_{\mathrm{y}}=17,58 \mathrm{~cm}
\end{aligned}
$$

Rigidez dos nós :

Inércia das vigas que concorrem no nó: $I_{\text {efx }}=l_{\text {efy }}=54.140 \mathrm{~cm}^{4}$

Rigidez de cada nó:

$$
\begin{aligned}
\mathrm{G}_{A x} & =G_{A y}=1,0 \text { (engastadas na base ) } \\
G_{B x} & =\left(\Sigma I_{C} / \ell_{C}\right) /\left(\left.\Sigma \alpha\right|_{V} / \ell_{V}\right)= \\
& =\frac{2 \times 1263.144 / 350}{0,67 \times 102400(1 / 800+1 / 400)}=28 \\
G_{B y} & =\frac{257.355 / 350}{0,67 \times 54.140 / 900}=18
\end{aligned}
$$

Portanto: $\quad K_{x}=2,2$

$$
K_{y}=2,1
$$

Resultando as resistências de cálculo: 


$$
\begin{aligned}
& \bar{\lambda}_{x}=0,22 \\
& \bar{\lambda}_{y}=0,465 \\
& \rho_{x}=0,79 \\
& N_{e x}=431.360 \mathrm{kN} \\
& N_{e y}=916.440 \mathrm{kN} \\
& \phi_{0} N_{n}=14.800 \mathrm{kN} \\
& \phi N_{y}=18.730 \mathrm{kN} \\
& \phi_{0} M_{n x}=698.242 \mathrm{kN} \mathrm{cm} \\
& \phi_{b} M_{n y}=249.480 \mathrm{kN} \mathrm{cm}
\end{aligned}
$$

Solicitações de Cálculo ( máximas )

$$
\begin{aligned}
& N_{d}=9.630 \mathrm{kN} \\
& M_{d x}=135.380 \mathrm{kN} \\
& M_{d y}=21.237 \mathrm{kN}
\end{aligned}
$$

Somatórios ( equações de Iteração )

$$
\begin{gathered}
\sum=\frac{N_{d}}{\phi N_{y}}+\frac{M_{d x}}{\phi_{b} M_{n x}}+\frac{M_{d y}}{\phi_{b} M_{n y}}=0,80<1,0 \\
\sum=\frac{N_{d}}{\phi_{C} N_{n}}+\frac{C_{m x} M_{d x}}{\left(1-\frac{N_{d}}{0,73 N_{e x}}\right) \phi_{b} M_{n x}}+\frac{C_{m y} M_{d y}}{\left(1-\frac{N_{d}}{0,73 N_{e y}}\right) \phi_{b} M_{n y}}=0,91 \leq 1,0
\end{gathered}
$$

O perfil passa com folga, entretanto no segundo pavimento, embora com solicitações menores, o perfil pode não ter atender às condiçōes de segurança, uma vez que as resistências de cálculo diminuem, devido ao aumento do comprimento de flambagem. 
Para calcular os novos valores destas resistências, determina-se inicialmente a rigidez dos nós para o segundo pavimento:

$$
\begin{array}{ll}
\mathrm{G}_{A x}=\mathrm{GBx}_{B \mathrm{x}}=28 & \mathrm{~K}_{\mathrm{x}}=5,0 \\
\mathrm{G}_{A y}=\mathrm{GBy}=28 & \mathrm{~K}_{\mathrm{y}}=5,0
\end{array}
$$

as resistências de cálculo:

$$
\begin{array}{ll}
\bar{\lambda}_{x}=0,499 & N_{\text {ex }}=83.510 \mathrm{kN} \\
\bar{\lambda}_{y}=0,885 & N_{\text {ey }}=26.580 \mathrm{kN} \\
\rho_{y}=0,522 & \phi_{C} N_{n}=9.780 \mathrm{kN}
\end{array}
$$

As solicitações de cálculo, no segundo andar serão :

$$
\begin{aligned}
& M_{d}=8.870 \mathrm{kN} \\
& M_{d x}=89.056 \mathrm{kN} \mathrm{cm} \\
& M_{d y}=2826 \mathrm{kN} \mathrm{cm}
\end{aligned}
$$

Somatório: $\quad \Sigma=0,907+0,127+0,018=1,052 \cong 1,0$

Portanto, neste andar o perfil continua atendendo às solicitações.

\section{2- Segundo Lance (5o. andar)}

Perfil Final: CVS $800 \times 406$

Seção: 2 ch. $31,5 \times 600$ 1ch. $19 \times 737$

Propriedades Geométricas

$$
\begin{aligned}
& \mathrm{I}_{\mathrm{x}}=621.800 \mathrm{~cm}^{4} \\
& \mathrm{I}_{\mathrm{y}}=113.440 \mathrm{~cm}^{4} \\
& \mathrm{Z}_{\mathrm{x}}=17.100 \mathrm{~cm}^{3} \\
& \mathrm{Z}_{y}=5.830 \mathrm{~cm}^{3} \\
& \mathrm{~A}=\quad 518 \mathrm{~cm}^{2} \\
& \mathrm{i}_{\mathrm{x}}=\quad 34,65 \mathrm{~cm} \\
& \mathrm{i}_{y}=14,8 \mathrm{~cm}
\end{aligned}
$$


Rigidez dos nós:
Inércia das Vigas: $I_{\text {efx }}=102.400 \mathrm{~cm}^{4}$ $l_{\text {efy }}=54.140 \mathrm{~cm}^{4}$
$\mathrm{G}_{A x}=21$
$K_{x}=3,9$
$\mathrm{G}_{\text {Ay }}=13$
$K_{y}=2,9$
$\mathrm{G}_{\mathrm{By}}=14$
$G_{B y}=8$

Resistências de cálculo:

$$
\begin{aligned}
& \bar{\lambda}_{x}=0,438 \\
& \bar{\lambda}_{y}=0,762 \\
& \rho_{y}=0,68 \\
& N_{e x}=67.592 \mathrm{kN} \\
& N_{e y}=22.300 \mathrm{kN} \\
& \phi_{c} N_{n}=7.925 \mathrm{kN} \\
& \phi N_{y}=11.655 \mathrm{kN} \\
& \phi_{b} M_{n x}=384.740 \mathrm{kN} \mathrm{cm} \\
& \phi_{b} M_{n y}=131.175 \mathrm{kN} \mathrm{cm}
\end{aligned}
$$

Solicitaçōes de cálculo:

$$
\begin{aligned}
& \mathrm{N}_{\mathrm{d}}=7.115 \mathrm{kN} \\
& \mathrm{M}_{\mathrm{dx}}=43.403 \mathrm{kN} \mathrm{cm} \\
& \mathrm{M}_{\mathrm{dy}}=770 \mathrm{kN} \mathrm{cm}
\end{aligned}
$$


Somatórios:

$$
\begin{aligned}
& \Sigma=0,611+0,113+0,006=0,73<1,0 \\
& \Sigma=0,898+0,112+0,009=1,019 \cong 1,0
\end{aligned}
$$

\section{3- Terceiro Lance (90. andar)}

Perfil Final: CVS $720 \times 300$

Seção: 2 ch. $25 \times 550$

1ch. $16 \times 670$

Propriedades Geométricas:

$$
\begin{aligned}
& I_{x}=372.325 \mathrm{~cm}^{4} \\
& I_{y}=69.346 \mathrm{~cm}^{4} \\
& Z_{x}=11.350 \mathrm{~cm}^{3} \\
& Z_{y}=3.867 \mathrm{~cm}^{3} \\
& A=\quad 382 \mathrm{~cm}^{2} \\
& i_{x}=\quad 1,22 \mathrm{~cm} \\
& i_{y}=13,47 \mathrm{~cm}
\end{aligned}
$$

Rigidez dos nós:

$$
\begin{aligned}
& \text { Inércia das vigas: } I_{\mathrm{efx}}=102.400 \mathrm{~cm}^{4} \\
& I_{\text {efy }}=54.140 \mathrm{~cm}^{4} \\
& \begin{array}{llll}
\mathrm{G}_{A x}=11 & \mathrm{~K}_{\mathrm{x}}=2,9 & \mathrm{G}_{\mathrm{Ay}}=13 & \mathrm{~K}_{\mathrm{y}}=2,7 \\
\mathrm{G}_{\mathrm{Bx}}=8 & & \mathrm{G}_{\mathrm{By}}=5 &
\end{array}
\end{aligned}
$$

Resistências de cálculo:

$$
\begin{array}{ll} 
& N_{e x}=73.185 \mathrm{kN} \\
& N_{e y}=15.715 \mathrm{kN} \\
\bar{\lambda}_{x}=0,36 & \phi_{\mathrm{n}}=5.730 \mathrm{kN} \\
\bar{\lambda}_{y}=0,78 & \mathrm{~N}_{\mathrm{y}}=8.595 \mathrm{kN} \\
\rho_{\mathrm{y}}=0,667 & \phi_{b} \mathrm{M}_{\mathrm{nx}}=255.375 \mathrm{kN} \mathrm{cm} \\
\phi_{b} \mathrm{M}_{\mathrm{ny}}=87.000 \mathrm{kN} . \mathrm{cm}
\end{array}
$$


Solicitaçōes de cálculo:

$$
\begin{aligned}
& \mathrm{N}_{\mathrm{d}}=4.275 \mathrm{kN} \\
& \mathrm{M}_{\mathrm{dx}}=53.896 \mathrm{kN} \mathrm{cm} \\
& \mathrm{M}_{\mathrm{dy}}=2.578 \mathrm{kN} \mathrm{cm}
\end{aligned}
$$

Somatórios:

$$
\begin{aligned}
& \Sigma=0,497+0,211+0,030=0,738<1,0 \\
& \Sigma=0,746+0,195+0,040=0,98 \cong 1,0
\end{aligned}
$$

\section{4- Quarto Lance (130. andar)}

Perfil Final : CVS $600 \times 230$

Propriedades Geométricas:

$$
\begin{aligned}
& \mathrm{I}_{\mathrm{x}}=208.277 \mathrm{~cm}^{4} \\
& \mathrm{I}_{y}=37.978 \mathrm{~cm}^{4} \\
& \mathrm{Z}_{\mathrm{x}}=7.578 \mathrm{~cm}^{3} \\
& \mathrm{Z}_{y}=2.574 \mathrm{~cm}^{3} \\
& A=313 \mathrm{~cm}^{2} \\
& \mathrm{i}_{\mathrm{x}}=25,8 \mathrm{~cm} \\
& \mathrm{i}_{y}=11,02 \mathrm{~cm}
\end{aligned}
$$

Rigidez dos nós :

$$
\begin{array}{ll}
\text { Inércia das vigas: } & \mathrm{l}_{\text {efxx }}=91.525 \mathrm{~cm}^{4} \\
\mathrm{G}_{A x}=7,2 & \mathrm{l}_{\text {afy }}=54.140 \mathrm{~cm}^{4} \\
\mathrm{G}_{\mathrm{Bx}}=5^{\circ} & \mathrm{K}_{\mathrm{x}}=2,4 \\
\mathrm{G}_{A y}=4 & \\
\mathrm{G}_{\mathrm{By}}=2,7 & \mathrm{~K}_{\mathrm{y}}=1,8
\end{array}
$$

Resistências de cálculo: 


$$
\begin{array}{ll} 
& \mathrm{N}_{\mathrm{ex}}=59.793 \mathrm{kN} \\
& \mathrm{N}_{\mathrm{ey}}=19.390 \mathrm{kN} \\
\phi_{\mathrm{c}} \mathrm{N}_{\mathrm{n}}=5.330 \mathrm{kN} & \\
\bar{\lambda}_{\mathrm{x}}=0,36 & \mathrm{~N}_{\mathrm{y}}=7.040 \mathrm{kN} \\
\bar{\lambda}_{\mathrm{y}}=0,635 & \phi_{\mathrm{b}} \mathrm{M}_{\mathrm{nx}}=170.505 \mathrm{kN} \mathrm{cm} \\
\rho_{\mathrm{y}}=0,757 & \phi_{\mathrm{b}} \mathrm{M}_{\mathrm{ny}}=57.920 \mathrm{kN} \mathrm{cm}
\end{array}
$$

Solicitações de cálculo:

$$
\begin{aligned}
& \mathrm{N}_{\mathrm{d}}=4.034 \mathrm{kN} \\
& \mathrm{M}_{\mathrm{dx}}=36.460 \mathrm{kN} \mathrm{cm} \\
& \mathrm{M}_{\mathrm{dy}}=2.579 \mathrm{kN} \mathrm{cm}
\end{aligned}
$$

Somatórios :

$$
\begin{aligned}
& \Sigma=0,573+0,214+0,045=0,831<1,0 \\
& \Sigma=0,757+0,200+0,053=1,01 \cong 1,0
\end{aligned}
$$

\section{5- Quinto Lance (17o. andar)}

Perfil Final : CVS 550×169

Propriedades Geométricas:

$$
\begin{aligned}
& l_{x}=111.688 \mathrm{~cm}^{4} \\
& l_{y}=13.595 \mathrm{~cm}^{4} \\
& Z_{x}=4.580 \mathrm{~cm}^{3} \\
& Z_{y}=1.164 \mathrm{~cm}^{3} \\
& A=215 \mathrm{~cm}^{2}
\end{aligned}
$$




$$
\begin{aligned}
& i_{x}=22,88 \mathrm{~cm} \\
& i_{y}=\quad 7,95 \mathrm{~cm}
\end{aligned}
$$

Rigidez dos nós:

$$
\begin{array}{ll}
\text { Inércia das vigas: } & \mathrm{I}_{\text {efx }}=\mathrm{I}_{\text {efy }}=54.140 \mathrm{~cm}^{4} \\
\mathrm{G}_{A x}=6,2 & \mathrm{~K}_{\mathrm{x}}=2,2 \\
\mathrm{G}_{\mathrm{Bx}}=3,8 & \\
\mathrm{G}_{A y}=1,8 & \mathrm{~K}_{\mathrm{y}}=1,4 \\
\mathrm{G}_{\mathrm{By}}=1,0 &
\end{array}
$$

Resistências de cálculo:

$$
\begin{array}{ll} 
& N_{\text {ex }}=38.106 \mathrm{kN} \\
& N_{\text {ey }}=11.460 \mathrm{kN} \\
\phi_{\mathrm{C}} \mathrm{N}_{\mathrm{n}}=3.512 \mathrm{kN} \\
\bar{\lambda}_{\mathrm{x}}=0,38 & \phi \mathrm{N}_{\mathrm{y}}=4.838 \mathrm{kN} \\
\bar{\lambda}_{\mathrm{y}}=0,685 & \phi_{\mathrm{b}} \mathrm{M}_{\mathrm{nx}}=103.050 \mathrm{kN} \mathrm{cm} \\
\rho_{\mathrm{y}}=0,726 & \phi_{\mathrm{b}} \mathrm{M}_{\mathrm{ny}}=26.190 \mathrm{kN} \mathrm{cm}
\end{array}
$$

Solicitações de cálculo:

$$
\begin{aligned}
& N_{d}=2550 \mathrm{kN} \\
& M_{d x}=24.700 k N \cdot c m \\
& M_{d y}=1.390 \mathrm{kN} \cdot \mathrm{cm}
\end{aligned}
$$

Somatórios :

$$
\begin{aligned}
& \Sigma=0,528+0,240+0,053=0,82<1,0 \\
& \Sigma=0,726+0,225+0,065=1,02 \cong 1,0
\end{aligned}
$$


Em resumo, chegou-se aos perfis:

$$
\begin{aligned}
& P_{1}=\text { CVS } 900 \times 654 \\
& \mathrm{P}_{2}=\text { CVS } 800 \times 406 \\
& \mathrm{P}_{3}=\mathrm{CVS} 720 \times 300 \\
& \mathrm{P}_{4}=\text { CVS } 600 \times 230 \\
& P_{5}=\text { CVS } 550 \times 169
\end{aligned}
$$

Quanto às vigas dos pisos, foi necessário substituir as pertencentes aos andares mais baixos, nos planos dos eixos, uma vez que os momentos registrados nos apoios ultrapassavam os valores resistentes.

Para estas substituiçōes foram utilizados perfis de mesma altura e mesma largura, variando-se apenas as espessuras das chapas que compõe as seçōes. Este procedimento visa tão somente evitar problemas de alinhamento ou mesmo de acabamento quando da colocação dos fechamentos laterais e do fôrro.

Na verificação das vigas é suficiente confrontar o momento resistente nos apoios, com os obtidos nos relatórios de saída, lembrando que nos apoios, por serem perfis sem problemas de estabilidade local, o momento resistente é o de plastificação da seção. Vale também observar a ordem de grandeza destes momentos com o resistente da viga mista correspondente, que são bastante próximos, como pode ser visto no quadro seguinte:

\begin{tabular}{|c|r|r|r|}
\hline VIGA METÁLICA & $\phi_{b} M_{p \ell}(\mathbf{k N . c m})$ & $\phi_{b} M n(k N . c m)$ & $\phi_{b} M_{n^{\prime}} / \phi_{b} M_{p \ell}$ \\
\hline VS $500 \times 61$ & 30.874 & 34.815 & 1,13 \\
\hline VS $500 \times 73$ & 42.270 & 43.540 & 1,03 \\
\hline VS $500 \times 86$ & 51.320 & 49.775 & 0,97 \\
\hline VS 500 X 97 & 58.970 & 55.975 & 0,95 \\
\hline
\end{tabular}

Finalmente, o consumo de aço nesta estrutura pode ser estimado calculando-se:

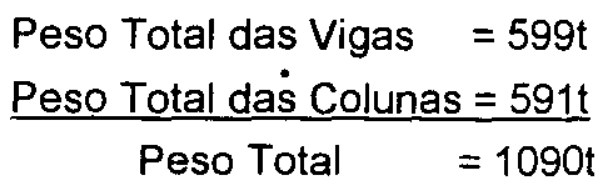

Considerando-se que a área construída total é de $18.000 \mathrm{~m}^{2}$ chega-se ao consumo médio de $60,6 \mathrm{~kg} / \mathrm{m}^{2}$. 


\section{5- EFEITO DE SEGUNDA ORDEM}

Como já mostrado no capítulo anterior, de uma forma bastante teórica, os efeitos da aplicação da teoria de segunda ordem em uma estrutura, já estão embutidos nas verificações das normas empregadas.

Assim é com a NBR-8800, que permite a determinação das solicitaçōes em teoria de primeira ordem, em regime elástico linear, introduzindo os termos $\mathrm{Cm}$ e $\mu$ nas equações de iteração e corrigindo o comprimento de flambagem da barra através do indice $K$, obtido do ábaco que considera o grau de engastamento de cada extremidade do elemento estrutural.

A introdução destes termos e a correção do comprimento de flambagem simulam, como se procurou demonstrar no capítulo anterior, a introdução destes efeitos. Este procedimento foi o utilizado na verificação das colunas que compõe a estrutura em análise, realizada no item anterior.

Entretanto, a NBR-8800, no anexo L, apresenta como sugestão, um dos métodos existentes para simular estes mesmos efeitos. Do mesmo modo o LRFD introduz os termos $B_{1}$ e $B_{2}$ nas suas equações com esta mesma finalidade.

A comparação destes procedimentos já foi feita no capítulo anterior, para um pórtico simples, com os mesmos valores para as açöes e tomados como de cálculo, nos três procedimentos, o que não ocorre na prática.

llustrando a aplicação destes procedimentos, para a estrutura mais complexa, pode-se recuperar as ações nominais da coluna do eixo 2, fila B, do quinto pavimento, para cada caso de carga, que são:

a-Devidas ao peso próprio $\left(P_{p}\right)$ :

$$
\begin{aligned}
& N=3.690 \mathrm{kN} \\
& M_{x}=-6.490 \mathrm{kN} \cdot \mathrm{cm} \\
& M_{y}=\quad 480 \mathrm{kN} \cdot \mathrm{cm}
\end{aligned}
$$

b-Devidas à sobrecarga $\left(\mathrm{S}_{\mathrm{C}}\right)$ :

$$
\begin{aligned}
& N=890 \mathrm{kN} \\
& M_{x}=1500 \mathrm{kN} \cdot \mathrm{cm} \\
& M_{y}=-117 \mathrm{kN} \cdot \mathrm{cm}
\end{aligned}
$$


c-Devidas ao vento, inclusive a torção (w):

$$
\begin{aligned}
& N=438 \mathrm{kN} \\
& M_{x}=39.100 \mathrm{kN} \cdot \mathrm{cm} \\
& M_{y}=1.155 \mathrm{kN} \cdot \mathrm{cm}
\end{aligned}
$$

Estas solicitaçōes, que são nominais, transformam-se em solicitações de cálculo, segundo a combinação crítica:

$$
C_{d}=1,4 P_{p}+1,5 S_{e}+1,4 w
$$

fornecendo: $N_{d}=7.115 \mathrm{kN} . \mathrm{cm}$

$M_{\mathrm{dx}}=43.403 \mathrm{kN} . \mathrm{cm}$

$M_{\text {dy }}=770 \mathrm{kN} \cdot \mathrm{cm}$

Entrando-se com estes valores na equação correspondente da NBR8800 , repetindo, por uma questão de facilidade, os valores já determinados das resistencias de cálculo:

$$
\begin{array}{rc}
\phi_{c} N_{n}= & 7.925 \mathrm{kN} \\
\phi N_{y}= & 11.655 \mathrm{kN} \\
\mathrm{N}_{\mathrm{ex}}= & 67.592 \mathrm{kN} \cdot \mathrm{cm} \\
\mathrm{N}_{\mathrm{ey}}= & 22.300 \mathrm{kN} \cdot \mathrm{cm} \\
\phi_{\mathrm{b}} \mathrm{M}_{\mathrm{nx}}= & 384.750 \mathrm{kN} \cdot \mathrm{cm} \\
\phi_{\mathrm{b}} \mathrm{Mny} & =131.175 \mathrm{kN} \cdot \mathrm{cm}
\end{array}
$$

e, os valores dos coeficientes: $C m_{x}=C m_{y}=0,85$ encontra-se:

$$
\frac{N}{N_{d}}+\frac{C_{m x} M_{d x}}{\left(1-\frac{N_{d}}{0,73 N_{e x}}\right) \phi_{b} M_{n x}}+\frac{C_{m y} M_{d y}}{\left(1-\frac{N_{d}}{0,73 N_{e y}}\right) \phi_{b} M_{n y}}=1,019 \cong 1,0
$$

Portanto, o perfil atende às solicitações, considerando os efeitos de segunda ordem que estão embutidos nesta equação.

Aplicando-se o procedimento do LRFD, com as mesmas condiçōes anteriores, ou seja, considerando a estrutura como deslocável, observa-se que os valores dos coeficientes de majoração das ações são diferentes dos fornecidos pela NBR-8800, ou seja: 


$$
\mathrm{C}_{\mathrm{d}}=1,2 \mathrm{P}_{\mathrm{p}}+1,3 \mathrm{w}+0,5 \mathrm{~S}_{\mathrm{c}} \quad \text { (equação } \mathrm{A} 4-4 \text { do LRFD) }
$$

podendo-se assumir como solicitações nominais as mesmas utilizadas anteriormente, pois a forma de obtê-las independe da norma a utilizar para combiná-las entre si.

Então, dentro deste procedimento os valores das solicitações de cálculo, obtidas pela combinação critica serão:

$$
\begin{aligned}
& P_{u}=5.442 k N \\
& M_{u}=B_{1} M_{n t}+B_{2} M_{t t}
\end{aligned}
$$
serão:

$E$, os momentos de cálculo devidos somente às ações verticais

$$
\begin{aligned}
& M_{\text {ntx }}=-8.538 \mathrm{kN} . \mathrm{cm} \\
& M_{\text {nty }}=-635 \mathrm{kN} . \mathrm{cm}
\end{aligned}
$$

$E$, os devidos somente às ações horizontais:

$$
\begin{aligned}
& M_{\ell \mathrm{tx}}=50.830 \mathrm{kN} . \mathrm{cm} \\
& M_{\ell \mathrm{ty}}=1.502 \mathrm{kN} . \mathrm{cm}
\end{aligned}
$$

Os valores dos coeficientes $B_{1}$ e $B_{2}$ são calculados pelas expressōes, já apresentadas no capitulo anterior:

$$
\begin{aligned}
& \mathrm{B}_{1}=\mathrm{Cm} /\left(1-\mathrm{P}_{\mathrm{u}} / \mathrm{P}_{\mathrm{e}}\right) \geq 1,0 \\
& \mathrm{~B}_{2}=1 /\left[1-\Sigma \mathrm{P}_{\mathrm{u}}\left(\Delta_{\mathrm{o}} / \Sigma \mathrm{H} \ell\right)\right]
\end{aligned}
$$

onde:

$$
\begin{aligned}
& \mathrm{P}_{\mathrm{ex}}=1.028 .075 \mathrm{kN} \quad(\mathrm{K}=1,0) \\
& \mathrm{P}_{\text {ey }}=187.560 \mathrm{kN} \quad(\mathrm{K}=1,0) \\
& \Sigma \mathrm{P}_{\mathrm{u}}=14 \times 5.740=80.360 \mathrm{kN} \\
& \Sigma \mathrm{H}_{\mathrm{x}}=6 \times 492,3=2.953,8 \mathrm{kN} \\
& \Sigma \mathrm{H}_{\mathrm{y}}=4 \times 253,7=1.014,8 \mathrm{kN} \\
& \Delta_{\mathrm{xo}}=0,4967 \mathrm{~cm} \\
& \Delta_{\mathrm{yo}}=0,4109 \mathrm{~cm} \\
& \mathrm{C}_{\mathrm{mx}}=\mathrm{C}_{\mathrm{my}} \cong 0,3
\end{aligned}
$$

Encontrando-se:

$$
\begin{aligned}
& B_{1 x}=B_{1 y}=1,0 \\
& B_{2 x}=1,0402 \\
& B_{2 y}=1,1025
\end{aligned}
$$


Portanto:

$$
\begin{aligned}
& M_{u x}=44.335 \mathrm{kN} . \mathrm{cm} \\
& M_{u y}=1021 \mathrm{kN} . \mathrm{cm}
\end{aligned}
$$

As resistencias de cálculo à flexão são as mesmas já calculadas:

$$
\begin{aligned}
& \phi_{c} M_{n x}=384.750 \mathrm{kN} . \mathrm{cm} \\
& \phi_{b} M_{n y}=131.175 \mathrm{kN} . \mathrm{cm}
\end{aligned}
$$

A resistência à compressão será:

$$
\begin{array}{ll} 
& R d=\phi_{c} P_{n} \quad \text { onde: } \phi_{c}=0,85 \\
& P_{n}=A_{g} \cdot F_{c r}=A_{g}\left(0,658^{\bar{\lambda}^{2}}\right) F_{y} \\
\text { como: } \quad \bar{\lambda}_{x}<\bar{\lambda}_{y}<1,5 &
\end{array}
$$

Então: $\phi_{\mathrm{c}} P_{\mathrm{n}}=8.860 \mathrm{kN}$

A equação de iteração a ser usada, uma vez que a razão $P_{u} / \phi P_{n}$ é maior do que 0,2 será:

$$
\frac{P_{u}}{\phi P_{n}}+\frac{8}{9}\left(\frac{M_{u x}}{\phi_{b} M_{n x}}+\frac{M_{u y}}{\phi_{b} M_{n y}}\right)=0,724<1,0
$$

Como pode ser observado, pelas recomendações do LRFD o perfil está bastante folgado, enquanto que pela NBR-8800 o perfil não possui reserva de resistência.

A redução feita na sobrecarga, que é permitida pela NBR-6120, também está prevista na AISE\#13 [ 20 ], inclusive com os mesmos valores percentuais. Portanto, parece que alguns fatores precisam ser ajustados, pois o esperado é que as duas normas conduzam a resultados bem próximos entre si, o que não ocorreu neste caso.

Como os dois procedimentos utilizados baseiam-se em análises aproximadas, é interessante buscar uma terceira resposta para o problema, e se possivel baseada em análise mais "exata". 
Para isto pode ser utilizado o procedimento recomendado pela NBR8800 para determinar solicitações em teoria de segunda ordem que, como já mostrado no capítulo anterior, parte do mesmo embasamento matemático do método contido no LRFD.

$\mathrm{Na}$ aplicação deste procedimento devem ser tomados alguns cuidados na determinação das resistencias e das solicitações de cálculo para esta nova situação. A resistência de cálculo do perfil à compressão deve ser determinada para a condição indeslocável, ou seja, o valor de $K_{x} e$ $\mathrm{K}_{\mathrm{y}}$ devem ser obtidos do gráfico correspondente da figura 18 , do anexo $\mathrm{I}$. Neste caso os valores obtidos são:

$$
\begin{aligned}
& K_{x}=0,9 \\
& K_{y}=0,88
\end{aligned}
$$

e, as esbeltez reduzidas serão:

$$
\begin{aligned}
& \bar{\lambda}_{x}=0,10 \\
& \bar{\lambda}_{y}=0,23
\end{aligned}
$$

Que permitem determinar as novas resistências à compressão:

$$
\begin{aligned}
& \mathrm{N}_{\text {ex }}=1.269 .230 \mathrm{kN} \\
& \mathrm{N}_{\text {ey }}=42.200 \mathrm{kN} \\
& \phi_{\mathrm{C}} \mathrm{N}_{\mathrm{n}}=\quad 11.480 \mathrm{kN}(>44,86 \%)
\end{aligned}
$$

As resistências à flexão são as mesmas já determinadas na situação deslocável, uma vez que são determinadas para o perfil isolado.

Para a determinação das solicitações, é necessário utilizar valores de cálculo para as ações, observando-se que a NBR- 8800 indica neste caso a adoção dos coeficientes de majoração plenos, o que não está de acordo com a NBR-8681 e tampouco com as teorias desenvolvidas sobre este tema.

Como se sabe, nas estruturas com comportamento linear, o coeficiente de majoração tanto pode ser aplicado nas ações, como nas solicitações, para transformá-las em ações ou em solicitações de cálculo. Entretanto, nas estruturas com comportamento não linear, deve ser aplicado uma parte do coeficiente pleno nas ações e a restante nas solicitações, para obter assim as solicitaçõs de cálculo. 
Chamando o coeficiente pleno, a ser aplicado nas estruturas com comportamento linear, de $\gamma_{f}$ como faz a NBR-8681 e dentro da nomenclatura desta mesma norma, de $\gamma_{\mathrm{f} 1}$ e $\gamma_{\mathrm{f} 3}$ os coeficientes parciais a serem aplicados às açōes e às solicitaçōes em estruturas não lineares, as seguintes limitações devem ser mantidas:

$$
\begin{aligned}
& \gamma_{f}=\gamma_{f 1} \cdot \gamma_{f 2} \cdot \gamma_{f 3} \\
& \gamma_{f 3} \geq 1,1
\end{aligned}
$$

lembrando, que $\gamma_{\mathfrak{f} 2}$ é o fator de combinação, também notificado como $\psi_{\mathrm{o}}$.

A quantificação portanto dos fatores, dentro das limitações anteriores fica a critério do projetista e para a estrutura em estudo optou-se pelos seguintes valores:

-Ação permanente e ação variável principal, que foi assumida como sendo a ação do vento:

$$
\begin{aligned}
\gamma_{f 1} & =1,15 \\
\gamma_{f 2} & =1,0 \\
\gamma_{f 3} & =1,2174>1,1
\end{aligned}
$$

Resultando: $\gamma_{\mathrm{f}}=1,4$

-Ação variável secundária, representada pela ação de sobrecarga:

$$
\begin{aligned}
& \gamma_{\mathrm{f} 1}=1,2321 \\
& \gamma_{\mathrm{f} 2}=1,0 \text { (decorrente do uso) } \\
& \gamma_{\mathrm{f} 3}=1,2174>1,1
\end{aligned}
$$

Resultando: $\gamma_{\mathrm{f}}=1,5$

Definidos os coeficientes de majoração das ações e das solicitações, é possível determinar as ações de cálculo obtendo-se:

\section{1-Ações verticais}

\section{1- Peso próprio}

-Vigas metálicas:

$$
P_{1}=0,7 \times 20 \times 6(20+45)=5460 \mathrm{kN}
$$

-Laje e revestimentos da cobertura:

$$
P_{2}=3,0 \times 900=2.700 \mathrm{kN}
$$


-Pisos dos andares:

$$
P_{3}=4,15 \times 19 \times 900=70.965 \mathrm{kN}
$$

-Paredes:

$$
P_{4}=3 \times 19,5(40+90)=7.605 \mathrm{kN}
$$

Sendo: $P_{d 1}=1,15 \Sigma P_{i}=99.739,5 k N$

\section{2- Sobrecarga}

$$
P_{5}=2 \times 900 \times 20 \times 0,52=18.720 \mathrm{kN}
$$

Sendo: $P_{d 2}=1,2321 \Sigma P_{i}=23.065 k N$

1.3- Ação total em cada pórtico e em cada andar:

$$
\Sigma P_{\mathrm{i}} / \mathrm{h}=\left(\mathrm{P}_{\mathrm{d} 1}+\mathrm{P}_{\mathrm{d} 2}\right) / 20 \times 350 \times 6=2,924 \mathrm{kN} / \mathrm{m}
$$

\section{2-Ações Horizontais}

2.1- Totais aplicados na estrutura

$$
\begin{aligned}
& \Sigma H_{d}=2.953,8 \times 1,15=3.396,87 \mathrm{kN} \\
& M_{T d}=1,15 M_{T}=22.928,87 \mathrm{kN} \cdot \mathrm{m}
\end{aligned}
$$

2.2- Totais aplicados nos pórticos, distribuídos segundo a rigidez e a posição relativa de cada pórtico.

$$
\begin{aligned}
& H_{d 1}=509,03+312,06=821,09 \mathrm{kN} \\
& H_{d 2}=594,70+218,75=813,45 \mathrm{kN} \\
& H_{d 3}=594,70+72,92=667,62 \mathrm{kN} \\
& H_{d 4}=594,70-72,92=521,78 \mathrm{kN} \\
& H_{d 5}=594,70-218,75=375,95 \mathrm{kN} \\
& H_{d 6}=509,03-312,06=196,97 \mathrm{kN} \\
& H_{d A}=-H_{d D}=111,72 \mathrm{kN} \\
& H_{d B}=-H_{d C}=22,35 \mathrm{kN}
\end{aligned}
$$

2.3- Forças horizontais de cálculo aplicadas no pórtico do eixo 2 ,

possuem distribuição proporcionais aos valores nominais:

$$
H_{i d}=\dot{H_{i}}\left(H_{d 2} / \Sigma H_{i}\right)=1,652 H_{i}
$$

Com estes valores é possivel dar início ao procedimento proposto na NBR-8800, determinando os valores necessários a cada iteração, ou seja: 


$$
\begin{aligned}
& V_{i}^{\prime}=\frac{\sum P_{i}}{h}\left(\Delta_{i+1}-\Delta_{i}\right) \\
& H_{i}^{\prime}=V_{i-1}^{\prime}-V_{i}^{\prime}
\end{aligned}
$$

Para iniciar o processo, calculam-se inicialmente os deslocamentos nos andares $\left(\delta_{\text {od }}\right)$ causados pelas ações de cálculo $\left(H_{\text {od }}\right)$. A seguir, os valores dos deslocamentos relativos $\left(\Delta_{\text {od }}\right)$ entre dois andares consecutivos, que multiplicados pelo valor do somatório das forças verticais $\left(\Sigma \mathbf{P}_{\mathbf{i}} / \mathbf{h}\right)$, fornecem os valores das forças cortantes fictícias $\left(\mathbf{V}_{\mathbf{i}}\right)$ localizadas em cada andar. Calculam-se, com estes valores, as forças horizontais fictícias que atuam em cada andar $\left(\mathbf{H}_{\mathrm{i}}{ }_{\mathrm{i}}\right)$. Somam-se estas forças às forças horizontais iniciais $\left(\mathbf{H}_{\text {od }}\right)$ e, com as ações assim obtidas $\left(\mathbf{H}_{\mathbf{1 d}}\right)$ calculam-se os novos deslocamentos $\left(\boldsymbol{\Delta}_{\mathbf{1}}\right)$ que permitem iniciar uma nova iteração.

Como parte do processo, continua-se repetindo este procedimento até que o resultado de uma iteração, coincida com o resultado da imediatamente anterior, ou então, que a diferença entre duas iterações sucessivas atinja um determinado valor pré-fixado.

Quando esta iteração ocorre, pode-se admitir que a estrutura convergiu para a posição de equilibrio.

$\mathrm{Na}$ estrutura em estudo foram necessárias quatro iterações para que o sistema convergisse. Como ilustração do trabalho dispendido, apresentase, na sequência, as planilhas que permitem o acompanhamento destas iterações, chamando-se a atenção, de que a convergência ocorreu primeiro em têrmos do somatório das forças fictícias horizontais $H_{i}$. 
Valores iniciais para o início do processo:

\begin{tabular}{|c|c|c|c|c|c|}
\hline Andar & $H_{i n}$ & Hida & $\delta_{\text {idn }}$ & $\Delta_{\text {ido }}$ & $\Sigma P_{i} / h$ \\
\hline 1 & 13,6 & 22,472 & 0,2174 & 0,2174 & 58,4787 \\
\hline 2 & 16,5 & 27,264 & 0,7228 & 0,5054 & 55,5547 \\
\hline 3 & 18,2 & 30,073 & 1,3734 & 0,6506 & 52,6308 \\
\hline 4 & 19,6 & 32,386 & 2,0948 & 0,7214 & 49,7069 \\
\hline 5 & 21,1 & 34,865 & 2,8749 & 0,7801 & 46,7829 \\
\hline 6 & 22,0 & 36,352 & 3,6697 & 0,7948 & 43,8590 \\
\hline 7 & 23,1 & 38,169 & 4,4562 & 0,7865 & 40,9351 \\
\hline 8 & 24,0 & 39,656 & 5,2268 & 0,7706 & 38,0111 \\
\hline 9 & 24,6 & 40,648 & 5,9976 & 0,7708 & 35,0872 \\
\hline 10 & 25,4 & 41,970 & 6,7375 & 0,7399 & 32,1633 \\
\hline 11 & 26,0 & 42,961 & 7,4456 & 0,7081 & 29,2393 \\
\hline 12 & 26,6 & 43,952 & 8,1329 & 0,6863 & 26,3154 \\
\hline 13 & 27,1 & 44,779 & 8,8288 & 0,5959 & 23,3915 \\
\hline 14 & 27,7 & 45,770 & 9,4777 & 0,6489 & 20,4675 \\
\hline 15 & 28,3 & 46,761 & 10,0824 & 0,6047 & 17,5436 \\
\hline 16 & 28,9 & 47,753 & 10,6833 & 0,6009 & 14,6197 \\
\hline 17 & 29,2 & 48,249 & 11,3188 & 0,6355 & 11,6957 \\
\hline 18 & 29,8 & 49,240 & 11,8627 & 0,5439 & 8,7718 \\
\hline 19 & 30,0 & 49,570 & 12,2957 & 0,4330 & 5.8479 \\
\hline 20 & 30,6 & 50,562 & 12,6262 & 0,3305 & 2,9239 \\
\hline$\Sigma$ & $492,3 \mathrm{kN}$ & $813,452 \mathrm{kN}$ & - & 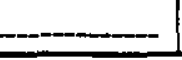 & $\cdots$ \\
\hline
\end{tabular}


Primeira Iteração:

\begin{tabular}{|c|c|c|c|c|c|}
\hline Andar & $v_{i 1}$ & $\mathrm{H}_{\mathrm{i1}}$ & $\mathrm{H}_{\text {id1 }}$ & $\delta_{i d 1}$ & $\Delta_{\mathrm{id1}}$ \\
\hline 1 & 12,7133 & $-15,3640$ & 7,1080 & 0,2237 & 0,2237 \\
\hline 2 & 28,0773 & $-6,1643$ & 21,0997 & 0,7488 & 0,5251 \\
\hline 3 & 34,2416 & $-1,6170$ & 28,4560 & 1,4282 & 0,6794 \\
\hline 4 & 35,8586 & $-0,6367$ & 31,7493 & 2,1833 & 0,7551 \\
\hline 5 & 36,4953 & 1,6362 & 36,5012 & 3,0017 & 0,8184 \\
\hline 6 & 34,8591 & 2,6636 & 39,0156 & 3,8362 & 0,8345 \\
\hline 7 & 32,1955 & 2,9041 & 41,0731 & 4,6616 & 0,8254 \\
\hline 8 & 29,2914 & 2,2462 & 41,9022 & 5,4699 & 0,8083 \\
\hline 9 & 27,0452 & 3,2476 & 43,8956 & 6,2776 & 0,8077 \\
\hline 10 & 23,7976 & 3,0933 & 45,0633 & 7,0517 & 0,7741 \\
\hline 11 & 20,7043 & 2,6177 & 45,5787 & 7,7912 & 0,7325 \\
\hline 12 & 18,0866 & 1,8085 & 47,7605 & 8,5082 & 0,7170 \\
\hline 13 & 16,2781 & 2,9967 & 47,7757 & 9,2335 & 0,7253 \\
\hline 14 & 13,2814 & 2,6728 & 48,4428 & 9,9087 & 0,6752 \\
\hline 15 & 10,6086 & 1,8236 & 48,5856 & 10,5368 & 0,6281 \\
\hline 16 & 8,7850 & 1,3524 & 49,1054 & 11,1606 & 0,6238 \\
\hline 17 & 7,4325 & 2,6616 & 50,9106 & 11,8202 & 0,6596 \\
\hline 18 & 4,7710 & 2,3389 & 51,4789 & 12,3835 & 0,5633 \\
\hline 19 & 2,5321 & 1,5658 & 51,1358 & 12,8309 & 0,4474 \\
\hline 20 & 0,9663 & 0,9663 & 51,5283 & 13,1674 & 0,3345 \\
\hline$\Sigma$ & 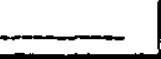 & $12,713 \mathrm{kN}$ & $826,165 \mathrm{kN}$ & 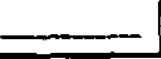 & $\ldots$ \\
\hline
\end{tabular}


Segunda Iteração

\begin{tabular}{|c|c|c|c|c|c|}
\hline Andar & $v_{i 2}$ & $\mathrm{H}_{\mathrm{i} 2}$ & $\mathrm{H}_{\mathrm{id} 2}$ & $\delta_{\text {id2 }}$ & $\Delta_{\mathrm{id} 2}$ \\
\hline 1 & 13,0817 & -16.901 & 6,3819 & 0,2239 & 0,2239 \\
\hline 2 & 29,1718 & $-6,5856$ & 20,6784 & 0,7499 & 0,5160 \\
\hline 3 & 35,7574 & $-1,7763$ & 28,2967 & 1,4306 & 0,6807 \\
\hline 4 & 37,5737 & $-0,7534$ & 31,6326 & 2,1873 & 0,7567 \\
\hline 5 & 38,2871 & 1,6868 & 36,5518 & 3,0074 & 0,8201 \\
\hline 6 & 36,6003 & 2,8125 & 39,1645 & 3,8439 & 0,8365 \\
\hline 7 & 33,7878 & 3,0634 & 41,2324 & 4,6712 & 0,8273 \\
\hline 8 & 30,7244 & 2,3845 & 42,0405 & 5,4812 & 0,8100 \\
\hline 9 & 28,3399 & 3,4423 & 44,0903 & 6,2907 & 0,8095 \\
\hline 10 & 24,8976 & 3,2751 & 45,2451 & 7,0664 & 0,7757 \\
\hline 11 & 21,6225 & 2,7544 & 45,7174 & 7,8073 & 0,7409 \\
\hline 12 & 18,8681 & 1,9022 & 45,8542 & 8,5255 & 0,7182 \\
\hline 13 & 16,9659 & 3,1462 & 47,9282 & 9,2522 & 0,7267 \\
\hline 14 & 43,8197 & 2,8006 & 48,4706 & 9,9285 & 0,6763 \\
\hline 15 & 11,0191 & 1,8993 & 48,6603 & 10,5575 & 0,6290 \\
\hline 16 & 9,1198 & 1,4053 & 49,1583 & 11,1822 & 0,6247 \\
\hline 17 & 7,7145 & 2,7733 & 51,0223 & 11,8428 & 0,6606 \\
\hline 18 & 4,9412 & 2,3298 & 51,5648 & 12,4067 & 0,5639 \\
\hline 19 & 2,6164 & 1,6384 & 51,2084 & 12,8547 & 0,4480 \\
\hline 20 & 0.9780 & 0,9780 & 51,5400 & 13,1965 & 0,3418 \\
\hline$\Sigma$ & - & $13,0817 \mathrm{kN}$ & $826,533 \mathrm{kN}$ & - & - \\
\hline
\end{tabular}


Terceira Iteração:

\begin{tabular}{|c|c|c|c|c|c|}
\hline Andar & $V_{i 3}$ & $\mathrm{H}_{\mathrm{i3}}$ & $\mathrm{H}_{\mathrm{in3} 3}$ & $\delta_{\mathrm{id} 3}$ & $\Delta_{\text {id3 }}$ \\
\hline 1 & 13,0934 & $-15,5728$ & 6,8992 & 0,2239 & 0,2239 \\
\hline 2 & 28,6662 & $-7,1596$ & 20,1044 & 0,7497 & 0,5258 \\
\hline 3 & 35,8258 & $-1,7874$ & 28,2856 & 1,4304 & 0,6807 \\
\hline 4 & 37,6132 & $-0,7535$ & 31,6325 & 2,1872 & 0,7568 \\
\hline 5 & 38,3567 & 1,6786 & 36,5436 & 3,0074 & 0,8202 \\
\hline 6 & 36,6881 & 2,8225 & 39,1745 & 3,8439 & 0,8365 \\
\hline 7 & 33,8656 & 3,0766 & 41,2456 & 4,6713 & 0,8274 \\
\hline 8 & 30,7890 & 2,3859 & 42,0419 & 5,4814 & 0,8101 \\
\hline 9 & 28,4031 & 3,4540 & 44,1020 & 6,2910 & 0,8096 \\
\hline 10 & 24,9491 & 3,2857 & 45,2557 & 7,0667 & 0,7755 \\
\hline 11 & 21,6634 & 2,7637 & 45,7247 & 7,8078 & 0,7411 \\
\hline 12 & 18,8997 & 1,9011 & 45,8531 & 8,5260 & 0,7182 \\
\hline 13 & 16,9986 & 3,564 & 47,9354 & 9,2527 & 0,7267 \\
\hline 14 & 13,8422 & 2.8073 & 48,5773 & 9,9291 & 0,6764 \\
\hline 15 & 11,0349 & 1,9020 & 48,6630 & 10,5582 & 0,6291 \\
\hline 16 & 9,1329 & 1,4067 & 49,1597 & 11,1829 & 0,6247 \\
\hline 17 & 7,7262 & 2,7798 & 51,0288 & 11,8435 & 0,6606 \\
\hline 18 & 4,9464 & 2,3265 & 51,5665 & 12,4075 & 0,5640 \\
\hline 19 & 2,6199 & 1,6205 & 51,1905 & 12,8556 & 0,4484 \\
\hline 20 & 0,9994 & 0,9994 & 51,5614 & 13,1974 & 0,8418 \\
\hline$\Sigma$ & - & $13,0934 \mathrm{kN}$ & $823,445 \mathrm{kN}$ & & \\
\hline
\end{tabular}


Quarta Iteração

\begin{tabular}{|c|c|c|c|c|c|}
\hline Andar & $v_{i 4}$ & $\mathrm{H}_{i 4}$ & $\mathrm{H}_{\mathrm{id} 4}$ & $\delta_{\text {id4 }}$ & $\Delta_{\text {id4 }}$ \\
\hline 1 & 13,0934 & $-16,1173$ & 6,3547 & 0,2239 & 0,2239 \\
\hline 2 & 29,2107 & $-6,5151$ & 20,6489 & 0,7497 & 0,5258 \\
\hline 3 & 35,8258 & $-1,7924$ & 28,2806 & 1,4304 & 0,6807 \\
\hline 4 & 37,6182 & $-0,7531$ & 31,6329 & 2,1872 & 0,7568 \\
\hline 5 & 38,3713 & 1,6832 & 36,5482 & 3,0074 & 0,8202 \\
\hline 6 & 36,6881 & 2,8184 & 39,1704 & 3,8439 & 0,8365 \\
\hline 7 & 33,8697 & 3,0769 & 41,2459 & 4,6713 & 0,8274 \\
\hline 8 & 30,7928 & 2,3862 & 42,0422 & 5,4814 & 0,8101 \\
\hline 9 & 28,4066 & 3,4640 & 44,1120 & 6,2910 & 0,8096 \\
\hline 10 & 24,9426 & 3,2734 & 45,2434 & 7,0667 & 0,7755 \\
\hline 11 & 21,6692 & 2,7695 & 95,7304 & 7,8078 & 0,7411 \\
\hline 12 & 18,8997 & 1,9011 & 45,8531 & 8,5260 & 0,7182 \\
\hline 13 & 13,9986 & 3,1544 & 47,9334 & 9,2527 & 0,7267 \\
\hline 14 & 13,8442 & 2,8075 & 48,5775 & 9,9291 & 0,6764 \\
\hline 15 & 11,0367 & 1,9038 & 48,6648 & 10,5582 & 0,6291 \\
\hline 16 & 9,1329 & 1,4067 & 49,1597 & 11,1829 & 0,6247 \\
\hline 17 & 7,7262 & 2,7789 & 51,0279 & 11,8435 & 0,6606 \\
\hline 18 & 4,9473 & 2,3269 & 51,5669 & 12,4075 & 0,5640 \\
\hline 19 & 2,6204 & 1,6210 & 51,1910 & 12,8556 & 0,4484 \\
\hline 20 & 0,9994 & 0,9994 & 51,5614 & 13,1974 & 0,8418 \\
\hline$\Sigma$ & 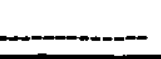 & $13,0934 \mathrm{kN}$ & $826,545 \mathrm{kN}$ & - & \\
\hline
\end{tabular}

A posição de equilibrio que a estrutura atinge na última iteração determina as seguintes solicitações no pilar da fila $B$, eixo 2 , do quinto andar:

$$
\begin{aligned}
& N=820 \mathrm{kN}(>87 \%) \\
& M_{x}=46.560 \mathrm{kN} \cdot \mathrm{cm}(>19 \%) \\
& M_{y}=1.370 \mathrm{kN} \cdot \mathrm{cm}(>18,6 \%)
\end{aligned}
$$

que, multiplicadas por $\gamma_{\mathrm{f} 3}=1,2174$ resultam nas solicitaçòes de cálculo: 


$$
\begin{aligned}
& N_{d}=1.000 \mathrm{kN} \cdot \mathrm{cm} \\
& M_{d x}=56.685 \mathrm{kN} \cdot \mathrm{cm} \\
& M_{d y}=1.670 \mathrm{kN} \cdot \mathrm{cm}
\end{aligned}
$$

Somando-se às ações de cálculo devidas às ações verticais, obtémse:

$$
\begin{array}{ll}
N_{d}=7.500 \mathrm{kN} & (>5,4 \%) \\
M_{d x}=45.350 \mathrm{kN} \cdot \mathrm{cm} & (>4,5 \%) \\
M_{\mathrm{dy}}=825 \mathrm{kN} \cdot \mathrm{cm} & (>7,14 \%)
\end{array}
$$

Considerando que os valores de $C_{m x}=e_{m y}$ são menores que 0,4 e a NBR-8800 fixa este valor como mínimo, nas equações de iteração encontra-se:

$$
\begin{gathered}
\frac{N_{d}}{\phi N_{y}}+\frac{M_{d x}}{\phi_{b} M_{n y}}+\frac{M_{d y}}{\phi_{b} M_{n y}}=0,77<1,0 \\
\frac{N_{d}}{\phi_{c} N_{n}}+\frac{C_{m x} M_{d x}}{\left(1-\frac{N_{d}}{0,73 N_{e x}}\right) \phi_{b} M_{n x}}+\frac{C_{m y} M_{d y}}{\left(1-\frac{N_{d}}{0,73 N_{e y}}\right) \phi_{b} M_{n y}}=0,71<1,0
\end{gathered}
$$

Aplicando o procedimento do LRFD para estruturas indeslocáveis, determina-se inicialmente:

$$
\begin{array}{ll}
\mathrm{K}=0,65 \\
\lambda_{\mathrm{c}}=\frac{\mathrm{K} \ell}{r \pi} \sqrt{\mathrm{F}_{\mathrm{y}} / \mathrm{E}}=0,188<1,5 \\
\mathrm{~F}_{\mathrm{cr}}=\left(0,658^{\lambda_{c}^{2}}\right) \mathrm{F}_{\mathrm{y}}=24,63 \mathrm{kN} / \mathrm{cm}^{2} \\
\phi_{\mathrm{c}} \mathrm{P}_{\mathrm{n}}=0,85 \mathrm{~A}_{\mathrm{g}} \mathrm{F}_{\mathrm{cr}}=10.845 \mathrm{kN}(>22,4 \%) \\
\mathrm{P}_{\mathrm{ex}} \cong \mathrm{P}_{\mathrm{ey}}=\mathrm{A}_{\mathrm{g}} \mathrm{F}_{\mathrm{y}} / \lambda_{\mathrm{c}}^{2}=366.400 \mathrm{kN} \\
\mathrm{C}_{\mathrm{mx}} \cong \mathrm{C}_{\mathrm{my}}=\mathrm{C}_{\mathrm{m}}=0,6-0,4\left(\mathrm{M}_{1} / \mathrm{M}_{2}\right) \\
\mathrm{com}: \quad \mathrm{M}_{1}=40.982 \mathrm{kN} \cdot \mathrm{cm} \\
\mathrm{M}_{2}=46.557 \mathrm{kN} \cdot \mathrm{cm} \\
\left.\mathrm{C}_{\mathrm{m}}=0,25 \quad \text { (não há mais limitação }\right) \\
\mathrm{P}_{\mathrm{u}}=1.2 \times 3690+0,5 \times 890+1,0435 \times 820=5.730 \mathrm{kN}(>5,29 \%)
\end{array}
$$


Sendo que neste caso, estrutura indeslocável, deve ser feito:

$$
\begin{aligned}
& M_{u}=B_{1} M_{n} \\
& B_{1}=\left[C_{m} /\left(1-P_{u} / P_{e}\right)\right]=0,25<-1,0
\end{aligned}
$$

Portanto: $B_{1}=1,0$ e os momentos finais de cálculo serão:

$$
\begin{aligned}
& M_{u x}=-1,2 \times 6490-0,5 \times 1500+1,0435 \times 46560=40.046 \mathrm{kN} . \mathrm{cm} \\
& M_{u y}=-1,2 \times 480-0,5 \times 117+1,0435 \times 1370=795 \mathrm{kN} . \mathrm{cm}
\end{aligned}
$$

Os valores dos momentos resistentes não se alteram, sendo os mesmos já determinados segundo a NBR-8800.

Finalmente: $P_{u} / \phi P_{n}=0,53>0,2$ portanto:

$$
\frac{P_{u}}{\phi P_{n}}+\frac{8}{9}\left(\frac{M_{u x}}{\phi_{b} M_{n x}}+\frac{M_{u y}}{\phi_{b} M_{n y}}\right)=0,63<1,0
$$

\section{6- PROCEDIMENTO ALTERNATIVO}

A determinação das solicitações em teoria de segunda ordem, pelo procedimento contido na NBR-8800, como pode ser visto no item anterior, é bastante trabalhoso e aplicável apenas a estruturas planas.

Para a estrutura em análise é necessário repetir o processo para os demais pórticos e, após determinar os deslocamentos finais em todos os andares e em todos os pórticos, resta verificar se os mesmos mantém entre si o alinhamento definido pela presença das lajes ao nível dos andares.

Em se tratando de uma análise de comportamento não linear, parece óbvio que a relação de dependência não será mantida, exigindo assim um rearranjo, nas forças fictícias e nos deslocamentos finais, tal como 0 realizado quando da análise da estrutura em estado de serviço. Caso este rearranjo tenha de ser excecutado, todo o processo precisará ser refeito.

Entretanto, se a determinação apenas dos deslocamentos do topo, permitiu, com grande precisão, a distribuição da força de arrasto e do momento de torção, entre os pórticos que formam a estrutura, é possivel e estaticamente correto, utilizar o mesmo procedimento na determinação dos efeitos de segunda ordem. 
Ou de outra forma, se os deslocamentos iniciais e os seus incrementos mantiveram entre si uma relação que dependia da rigidez e da posição relativa de cada pórtico, então as forças horizontais fictícias bem como os deslocamentos de segunda ordem devem manter esta mesma dependência, uma vez que a estrutura continua reagindo dentro do regime elástico linear.

Para aplicar este procedimento e mesmo para justificá-lo, é ncessário recuperar algunas passos do procedimento recomendado pela NBR-8800, uma vez que se pretende apenas tornar sua aplicação mais prática.

Então, no procedimento da NBR-8800 as equações fundamentais são:

$$
\begin{aligned}
& V_{i}=\left(\delta_{i+1}-\delta_{i}\right) \Sigma P_{i} / h=\Delta_{i} \Sigma P_{i} / h \\
& H_{i}=V_{i-1}-V_{i}
\end{aligned}
$$

Para a determinação do deslocamento do topo dos pórticos, precisase conhecer primeiramente, o total das forças horizontais aplicadas em cada pórtico, que é determinado somando-se às forças horizontais iniciais as forças horizontais fictícias.

O somatório das forças horizontais iniciais já é conhecido e, o somatório das forças fictícias pode ser calculado fazendo-se:

$$
\Sigma \mathrm{H}_{\mathrm{i}}=\Sigma\left(\mathrm{V}_{\mathrm{i}-1}-\mathrm{V}_{\mathrm{i}}\right)=-\mathrm{V}_{1}
$$

Portanto, o somatório procurado é, a menos do sinal, a própria força cortante fictícia $\mathbf{V}_{\mathbf{1}}$ que, por sua vez pode ser calculada pela expressão:

$$
V_{1}=\Delta_{1} \Sigma P_{i} / h
$$

devendo o somatório das forças $\mathbf{P}_{\mathbf{i}}$ ser estendido do nó $\mathbf{n}$ até o nó $\mathbf{1}$, ou seja do topo até a base. Este somatório representa a totalidade das forças verticais aplicadas no pórtico e, a força $V_{1}$ é obtida como o produto deste somatório pelo deslocamento final do primeiro nó.

Como a "priori" não se conhece o valor deste deslocamento, pode-se, com pequena margem de êrro, substituir na expressão de $V_{\mathbf{1}}$, o deslocamento do primeiro nó pela média dos deslocamentos iniciais e 0 somatório das forças verticais aplicadas no pórtico, pela média destas mesmas forças porém, das aplicadas em um andar, uma vez que busca-se uma análise tridimensional. 
A idéia básica que está embutida nesta substituição é que, se o somatório das forças fictícias pode ser determinado como o produto do deslocamento de um andar, pelas forças nele aplicadas, então o produto das médias dos deslocamentos e das forças aplicadas, não deve se afastar muito da solução.

Equacionando:

$$
\sum H_{i}=-V_{1}=\frac{\delta}{n} m \sum P_{i} / h
$$

onde $\mathbf{n}$ representa o número de andares e $\mathbf{m}$ o número de pórticos da estrutura.

Por esta equação é possivel calcular o total das forças fictícias horizontais aplicadas a cada pórtico, que amplificam os deslocamentos iniciais de translação e de torção. Como estas amplificações estão ligadas entre si pela laje de cobertura, caso os valores obtidos não mantenham esta relação, ocorrerá uma redistribuição destas forças entre os pórticos, sem contudo alterar os incrementos introduzidos na componente global e no momento de torção.

Deste modo:

$$
\begin{aligned}
& \Delta H_{0}=\Sigma V_{1 i} \\
& \Delta M_{T}=\Sigma\left(V_{1 i} x_{i}+V_{1 i} y_{i}\right)
\end{aligned}
$$

E as forças horizontais fictícias são distribuiídas, de maneira equilibrada, aos pórticos que formam a estrutura, pelas equaçôes já deduzidas:

$$
\Delta H_{i T}=\Delta \bar{H}_{i}+\Delta F_{i}
$$

sendo: $\quad \Delta \bar{H}_{i}=\sum H_{0} R_{i} / \sum R_{i}$

e $\quad \Delta F_{i}=\Delta M_{T} R_{i} j_{i} / \Sigma R_{i} j_{i}^{2}$

onde: $\quad R_{i}=$ rigidez relativa inicial de cada pórtico.

$\mathrm{j}_{\mathrm{i}}=$ distância do pórtico ao centro elástico $\left(x_{i}\right.$ ou $\left.y_{i}\right)$

Somando-se o valor das forças horizontais fictícias ao valor inicial, encontra-se o valor das açōes totais: 


$$
H_{\mathrm{iT}}=\mathrm{H}_{\mathrm{iO}}+\Delta \mathrm{H}_{\mathrm{iT}}
$$

que, divididas pela rigidez relativa dos pórticos, fornecem os deslocamentos totais do topo dos pórticos, agora perfeitamente alinhados.

$$
\delta_{\mathrm{iT}}=H_{\mathrm{iT}} / \mathrm{R}_{\mathrm{i}}
$$

Estes deslocamentos permitem iniciar um novo ciclo do processo, que deve continuar até ser atingida a convergência pré-estabelecida.

Aplicando o procedimento alternativo, determina-se inicialmente:

$$
\mathrm{m} \Sigma \mathrm{P}_{\mathrm{i}} / \mathrm{h}=6 \times 2,924=17,54 \mathrm{kN} / \mathrm{cm}
$$

Os demais dados já conhecidos, as operações, resultados e sequências iterativas estão condensados no quadro seguinte.

Primeira iteração

\begin{tabular}{|c|c|c|c|c|c|c|c|c|}
\hline$\Delta \overline{\mathrm{H}}$ & 7,18 & 8,45 & 8,45 & 8,45 & 8,45 & 7,18 & - & - \\
\hline$\Delta F$ & 4,85 & 7,00 & 1,13 & $-1,13$ & $-4,00$ & $-4,85$ & $\pm 1,74$ & $\pm 0,35$ \\
\hline $\mathrm{H}_{T}$ & 833,11 & 825,30 & 677,20 & 528,91 & 381,01 & 199,30 & 113,46 & 22,69 \\
\hline$\delta \mathcal{T}_{1}$ & 15,01 & 12,73 & 10,44 & 8,16 & 5,88 & 3,59 & 2,54 & 0,51 \\
\hline$-v_{2}$ & 13,17 & 11,15 & 9,16 & 7,15 & 5,15 & 3,15 & 2,23 & 0,45 \\
\hline
\end{tabular}

\begin{tabular}{|c|r|r|r|r|r|r|r|r|}
\hline FATOR & EIXO 1 & EIXO 2 & EIXO 3 & EIXO 4 & EIXO 5 & EIXO 6 & FILA A & FILA B \\
\hline$H_{0}$ & 821,08 & 813,45 & 667,62 & 521,79 & 375,96 & 196,97 & 111,72 & 22,35 \\
\hline$\delta_{0}$ & 14,79 & 12,54 & 10,29 & 8,05 & 5,80 & 3,55 & 2,50 & 0,50 \\
\hline$-V_{1}$ & 12,97 & 11,00 & 9,03 & 7,06 & 5,09 & 3,11 & 2,19 & 0,44 \\
\hline \multicolumn{7}{c}{$\Delta M_{T}=356,28 \mathrm{kN} \cdot \mathrm{m}$} \\
\hline
\end{tabular}

Segunda Iteração

Terceira Iteração

\begin{tabular}{|l|r|r|r|r|r|r|r|c|}
\hline$\Delta \bar{H}$ & 7,33 & 8,57 & 8,57 & 8,57 & 8,57 & 7,33 & - & - \\
\hline$\Delta F$ & 4,92 & 3,45 & 1,15 & $-1,15$ & $-3,45$ & $-4,42$ & $\pm 1,76$ & $\pm 0,35$ \\
\hline$H_{T}$ & 833,34 & 125,47 & 677,34 & 529,20 & 381,07 & 199,38 & 113,49 & 22,70 \\
\hline$\delta \tau 2$ & 15,01 & 12,73 & 10,44 & 8,16 & 5,88 & 3,59 & 2,54 & 0,51 \\
\hline
\end{tabular}

Como pode ser observado, a convergência ocorreu no segundo ciclo. 
Comparando o valor obtido para a açāo horizontal total, que cabe ao pórtico do eixo 2 por este processo, com o da NBR-8800, encontra-se uma diferença de $1,3 \%$, que não significa êrro, pois cabe lembrar que o método da NBR-8800 analisa apenas o comportamento no plano, nāo levando em conta a redistribuição de forças que ocorre em uma análise espacial.

Ainda para o pórtico do eixo 2 , determinou-se os deslocamentos em todos os andares, para compará-los com os obtidos pelo procedimento anterior, como pode ser visto no quadro seguinte, onde $\delta$ o são os deslocamentos calculados segundo a NBR $8800, \delta$ r são os deslocamentos calculados pelo processo aproximado e $\delta \mathrm{F}$ são os deslocamentos calculados por programa espacial ( LUSAS ).

\begin{tabular}{|c|c|c|c|}
\hline ANDAR & $\delta_{0}$ & $\delta_{\text {工 }}$ & $\delta_{\mathbf{E}}$ \\
\hline 1 & 0,22 & 0,22 & 0.22 \\
\hline 2 & 0,72 & 0,73 & 0.73 \\
\hline 3 & 1,37 & 1,39 & 1.38 \\
\hline 4 & 2,10 & 2,13 & 2.12 \\
\hline 5 & 2,88 & 2,92 & 2.90 \\
\hline 6 & 3,67 & 3,72 & 3.70 \\
\hline 7 & 4,46 & 4,52 & 4.49 \\
\hline 8 & 5,23 & 5,30 & 5.27 \\
\hline 9 & 6,00 & 6,09 & 6.05 \\
\hline 10 & 6,74 & 6,84 & 6.80 \\
\hline 11 & 7,45 & 7,56 & 7.51 \\
\hline 12 & 8,13 & 8,25 & 8.20 \\
\hline 13 & 8,83 & 8,96 & 8.90 \\
\hline 14 & 9,48 & 9,62 & 9.56 \\
\hline 15 & 10,08 & 10,23 & 10.17 \\
\hline 16 & 10,68 & 10,84 & 10.77 \\
\hline 17 & 11,32 & 11,49 & 11.42 \\
\hline 18 & 11,86 & 12,04 & 11.96 \\
\hline 19 & $+2,30$ & 12,48 & 12.40 \\
\hline 20 & 12,63 & 12,81 & 12,73 \\
\hline
\end{tabular}




\section{7- DINÂMICA DO VENTO}

A última verificação trata do comportamento dinâmico da estrutura para a ação do vento. Como já mostrado no capítulo anterior, a NBR-6123 fornece parâmetros, que permitem determinar, de maneira aproximada, a frequência natural da estrutura.

Por esta norma:

$$
f=\frac{1}{0,29 \sqrt{h}-0,4}=0,4935 \mathrm{cps}
$$

Pelo método de Raleigh, uma vez que são conhecidos os deslocamentos ao nivel dos andares $e$ as intensidades das ações aplicadas, a frequência pode ser calculada pela expressão:

$$
f=\frac{1}{2 \pi} \sqrt{\frac{g \sum F_{i} \delta_{i}}{\sum P_{i} \delta_{1}^{2}}}
$$

Encontra-se com os valores nominais das açöes, encontra-se:

$$
f=\frac{1}{2 \pi} \sqrt{\frac{981 \times 2 \cdot 236,4}{327.814,3}}=0,4117 \mathrm{cps}
$$

Como os dois valores são bastante próximos, será adotado o obtido pelo método de Raleigh, que possui melhor embasamento teórico.

A determinação da velocidade de projeto, bem como dos demais parâmetros não oferece maiores dificuldades, como pode ser observado nos passos seguintes:

$$
\begin{array}{ll}
\bar{V}_{p}=0,69 V_{0}=27,6 \mathrm{~m} / \mathrm{s} & \\
\bar{q}_{0}=0,613 \bar{V}_{p}^{2}=0,467 \mathrm{kN} / \mathrm{m}^{2} & \\
p=0,23 \text { (categoria IV) } & \bar{V}_{p} / \mathrm{fL}=0,033 \\
b=0,71 \text { (categoria IV) } & \xi=0,01 \\
\varepsilon=1,65
\end{array}
$$




\subsection{1- Método Simplificado}

Para utilizar o método simplificado é necessário determinar o valor da pressão ao longo da altura do edifício, que permite calcular os novos valores das ações horizontais.

$$
\begin{aligned}
& q_{(z)}=\bar{q}_{0} b^{2}\left[\left(z / z_{r}\right)^{2 p}+\varepsilon\left(h / z_{r}\right)^{p}(z / h)^{\gamma} \frac{1+2 \gamma}{1+\gamma+p}\right] \\
& H_{(z)}=q_{z} A_{i} C_{a}
\end{aligned}
$$

Como o fator $\gamma$ representa a contribuição nodal da estrutura, tomando-se para este fator o valor da unidade, obtém-se na resposta a contribuição apenas do primeiro modo de vibração da estrutura. Tomandose o valor de 1,2 como preconiza a NBR-6123, na tabela 19, do item 9, é incorporado também a contribuição do segundo modo de vibração, na resposta da estrutura.

Utilizando os dois valores, para verificar qual conduz a maiores solicitaçöes, encontra-se:

Para $\gamma=1,0$ :

$$
q_{(z)}=0,235\left[(z / 10)^{0,46}+3,473(z / 70)\right]
$$

Para $\gamma=1,2$ :

$$
q_{(z)}=0,235\left[(z / 10)^{0,46}+3,6118(z / 70)^{1,2}\right]
$$

No topo da construção com : $\quad z=70 \mathrm{~m}$

$$
\begin{aligned}
& C_{a}=1,1 \\
& A_{i}=70 \times 45 / 6 \times 20=26,25 \mathrm{~m}^{2}
\end{aligned}
$$

e as duas formulações conduzem aos seguintes resultados:

$$
\begin{array}{ll}
\mathrm{q}_{(70)}=1,391 \mathrm{kN} / \mathrm{m}^{2} & (\gamma=1,0) \\
\mathrm{q}_{(70)}=1,424 \mathrm{kN} / \mathrm{m}^{2} & (\gamma=1,2) \\
\mathrm{H}_{(70)}=40,165 \mathrm{kN} & (\gamma=1,0) \\
\mathrm{H}_{(70)}=41,118 \mathrm{kN} & (\gamma=1,2)
\end{array}
$$


Os valores de $q_{(z)}, H_{(z)}$ e $\delta_{(z)}$ para todos os andares e para os dois valores de $\gamma$ (deslocamentos horizontais, no primeiro e no segundo modo de vibração, obtidos pelo Método Simplificado ), que estão condensados no quadro seguinte:

\begin{tabular}{|c|c|c|c|c|c|c|c|}
\hline \multirow[b]{2}{*}{ ANDAR } & \multirow[b]{2}{*}{$z(m)$} & \multicolumn{3}{|c|}{$y=1,0$} & \multicolumn{3}{|c|}{$y=1,2$} \\
\hline & & $\begin{array}{c}q(z) \\
\left(k N / m^{2}\right) \\
\end{array}$ & $\begin{array}{c}\mathrm{H}_{\mathrm{i}} \\
(\mathrm{kN})\end{array}$ & $\delta_{\mathbf{i}}(\mathrm{cm})$ & $\begin{array}{c}q(z) \\
\left(k N / m^{2}\right) \\
\end{array}$ & $\begin{array}{c}\mathrm{H}_{\mathrm{i}} \\
(\mathrm{kN}) \\
\end{array}$ & $\delta_{i}(\mathbf{c m})$ \\
\hline 1 & 3,5 & 0,186 & 5,36 & 0,13 & 0,166 & 4,86 & 0,13 \\
\hline 2 & 7,0 & 0,281 & 8,12 & 0,44 & 0,253 & 7,31 & 0,43 \\
\hline 3 & 10,5 & 0,363 & 10,48 & 0,85 & 0,328 & 9,46 & 0,83 \\
\hline 4 & 14,00 & 0,438 & 12,64 & 1,30 & 0,397 & 11,47 & 1,27 \\
\hline 5 & 17,5 & 0,508 & 14,67 & 1,80 & 0,465 & 13,42 & 1,76 \\
\hline 6 & 21,00 & 0,575 & 16,62 & 2,32 & 0,531 & 15,33 & 2,27 \\
\hline 7 & 24,5 & 0,641 & 18,50 & 2,84 & 0,596 & 17,20 & 2,78 \\
\hline 8 & 28,0 & 0,704 & 20,32 & 3,35 & 0,660 & 19,06 & 3,29 \\
\hline 9 & 31,5 & 0,766 & 22,11 & 3,87 & 0,721 & 20,90 & 3,81 \\
\hline 10 & 35,0 & 0,826 & 23,86 & 4,39 & 0,783 & 22,74 & 4,32 \\
\hline 11 & 38,5 & 0,886 & 25,58 & 4,88 & 0,851 & 24,58 & 4,81 \\
\hline 12 & 42,0 & 0,944 & 27,27 & 5,37 & 0,913 & 25,41 & 5,30 \\
\hline 13 & 45.5 & 1,002 & 28,94 & 5,87 & 0,978 & 28,24 & 5,79 \\
\hline 14 & 49,0 & 1,059 & 30,59 & 6,34 & 1,041 & 30,07 & 6,27 \\
\hline 15 & 52,5 & 1,116 & 32,23 & 6,78 & 1,105 & 31,90 & 6,71 \\
\hline 16 & 56,0 & 1,172 & 33,84 & 7,22 & 1,149 & 33,74 & 7,16 \\
\hline 17 & 59,5 & 1,227 & 35,44 & 7,70 & 1,232 & 35,58 & 7,64 \\
\hline 18 & 63,0 & 1,283 & 37,03 & 8,11 & 1,296 & 37,42 & 7,05 \\
\hline 19 & 66,5 & 1,337 & 38,61 & 8,43 & 1,360 & 39,27 & 8,38 \\
\hline 20 & 70,0 & 1,391 & 40,18 & 8,68 & 1,424 & 41,12 & 8,63 \\
\hline$\Sigma$ & - & -_-_-_-_- & 482,39 & ב-ביב-ביביב- & 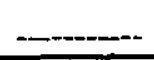 & 470,08 & 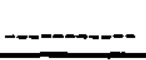 \\
\hline
\end{tabular}




\subsection{2- Método Discreto}

A aplicação do método discreto implica, necessariamente, em um maior número de operações que as utiliżadas no método simplificado.

Entretanto, é este o método que fornece o parâmetro indispensável para analisar o conforto dos usuários, que é o valor da aceleração. Possui ainda o inconveniente de computar apenas a contribuição do primeiro modo.

Para sua aplicação, precisa-se determinar inicialmente:

$$
\begin{aligned}
& \beta_{i}=C_{a} \frac{A_{i}}{A_{0}}\left(z_{i} / z_{r}\right)^{p} \\
& \psi=m_{i} / m_{0} \\
& F_{H}=\bar{q}_{0} b^{2} A_{0} \frac{\sum \beta_{i} \delta_{i}}{\sum \varphi_{i} \delta_{i}^{2}} \xi
\end{aligned}
$$

Os parâmetros ainda não conhecidos, possuem os seguintes valores:

$$
\begin{aligned}
& \mathrm{m}_{\mathrm{o}}=15.315 / \mathrm{g} \\
& \mathrm{m}_{\mathrm{i}}=\mathrm{m}_{1}=496 / \mathrm{g} \\
& \mathrm{m}_{2}=756 / \mathrm{g} \\
& \mathrm{m}_{3}=765 / \mathrm{g} \\
& \mathrm{m}_{4}=775 / \mathrm{g} \\
& \mathrm{m}_{5}=790 / \mathrm{g} \\
& m_{6}=825 / \mathrm{g}
\end{aligned}
$$

Recuperando os valores das ações horizontais iniciais, e os deslocamentos respectivos, calculam-se os valores de $\delta^{\mathbf{2}_{\mathbf{i}}}$ e $\beta_{\mathbf{i}}$ como está ilustrado no quadro seguinte: 


\begin{tabular}{|c|c|c|c|c|c|c|}
\hline ANDAR & $H_{0}=F_{i}$ & $\delta_{\mathbf{i}}$ & $\delta_{i}^{2}$ & $\mathbf{P}_{\mathbf{i}}$ & $\begin{array}{c}\Phi_{i}= \\
m_{i} / m_{0}\end{array}$ & $\beta_{\mathbf{i}}$ \\
\hline 1 & 13,6 & 0,132 & 0,017 & 125 & 0,054 & 0,043 \\
\hline 2 & 16.5 & 0,437 & 0,191 & & & 0,051 \\
\hline 3 & 18,2 & 0,831 & 0,691 & & & 0,056 \\
\hline 4 & 19,6 & 1,267 & 1,605 & 790 & 0,052 & 0,059 \\
\hline 5 & 21,1 & 1,739 & 3,024 & & & 0,063 \\
\hline 6 & 22,0 & 2,220 & 4,928 & & & 0,065 \\
\hline 7 & 23,1 & 2,695 & 7,263 & & & 0,068 \\
\hline 8 & 24,0 & 3,161 & 9,992 & 775 & 0,051 & 0,070 \\
\hline 9 & 24,6 & 3,627 & 13,155 & & & 0,072 \\
\hline 10 & 25,4 & 4,073 & 16,589 & & & 0,073 \\
\hline 11 & 26,0 & 4,498 & 20,232 & & & 0,075 \\
\hline 12 & 26,6 & 4,905 & 24,059 & 765 & 0,050 & 0,077 \\
\hline 13 & 27,1 & 5,307 & 28,164 & & & 0,078 \\
\hline 14 & 27,7 & 5,694 & 32,422 & & & 0,079 \\
\hline 15 & 28.3 & 6,058 & 36,699 & & & 0,081 \\
\hline 16 & 28,9 & 6,420 & 41,216 & 756 & 0,049 & 0,082 \\
\hline 17 & 29,2 & 6,803 & 46,281 & & & 0,083 \\
\hline 18 & 29,8 & 7,131 & 50,851 & & & 0,084 \\
\hline 19 & 30,0 & 7,392 & 54,642 & & & 0,085 \\
\hline 20 & 30,6 & 7,591 & 57,623 & 496 & 0,032 & 0,086 \\
\hline$\Sigma$ & 492,3 & & & 1531,5 & & \\
\hline
\end{tabular}

Com os valores já calculados é possível determinar:

$$
\begin{array}{lcc}
\sum F_{i} \delta_{i}= & 2,236,43 \mathrm{kN} . \mathrm{cm} \\
\sum \mathrm{P}_{\mathrm{i}} \delta_{\mathrm{i}}^{2}=327.814,28 \mathrm{kN} \cdot \mathrm{cm}^{2} \\
\sum \beta \delta_{\mathrm{i}}= & 6,029 \\
\sum \psi_{\mathrm{i}} \delta_{\mathrm{i}}^{2}= & 19,505 \\
\mathrm{~F}_{\mathrm{H}}={\overline{q_{0}}}_{\mathrm{a}} \mathrm{b}^{2} \mathrm{~A}_{\mathrm{o}} \frac{\sum \beta_{i} \delta_{\mathrm{i}}}{\sum \psi_{\mathrm{i}} \delta_{\mathrm{i}}^{2}} \xi=63 \mathrm{kN}
\end{array}
$$

que, por sua vez permitem calcular as últimas funções de $z$, indicadas a seguir, cujos valores estão registrados no quadro seguinte: 


$$
\begin{aligned}
& F_{e i}=\bar{q}_{0} b^{2} C_{a} A_{i}\left(z_{i} / z_{r}\right)^{2 p}=6,798\left(z_{i} / 10\right)^{0,46} \\
& F_{d i}=F_{H} \psi_{i} \delta_{i} \\
& F_{T}=F_{e i}+F_{d i}
\end{aligned}
$$

Os valores de $F_{\mathrm{T}}$, que representam a soma dos efeitos estático $\left(\boldsymbol{F}_{\mathrm{ei}}\right)$ com o dinâmico $\left(F_{\mathrm{di}}\right)$, permitem calcular os deslocamentos horizontais finais

\begin{tabular}{|c|c|c|c|c|c|}
\hline ANDAR & $F_{e i}$ & Fdi & $F_{I}$ & $\delta_{\mathrm{F}}$ & $\delta_{\mathrm{F}} / \delta_{\mathrm{i}}$ \\
\hline 1 & 4,194 & 0,449 & 4,6431 & 0,135 & 1,0714 \\
\hline 2 & 5,769 & 1,487 & 7,256 & 0,454 & 1,0708 \\
\hline 3 & 6,952 & 2,827 & 9,779 & 0,870 & 1,074 \\
\hline 4 & 7,936 & 4,151 & 12,087 & 1,337 & 1,0713 \\
\hline 5 & 8,794 & 5,697 & 14,491 & 1,351 & 1,0718 \\
\hline 6 & 9,563 & 7,273 & 16,836 & 2,384 & 1,0715 \\
\hline 7 & 10,266 & 8,829 & 19,095 & 2,920 & 1,0712 \\
\hline 8 & 10,916 & 10,156 & 21,072 & 3,453 & 1,0707 \\
\hline 9 & 11,524 & 11,654 & 23,178 & 3,994 & 1,0699 \\
\hline 10 & 12,096 & 13,087 & 25,183 & 4,520 & 1,0688 \\
\hline 11 & 12,638 & 14,452 & 27,090 & 5,031 & 1,0677 \\
\hline 12 & 13,155 & 15,451 & 28,606 & 5,531 & 1,0663 \\
\hline 13 & 13,648 & 16,717 & 30,365 & 6,043 & 1,0648 \\
\hline 14 & 14,121 & 17,936 & 32,057 & 6,525 & 1,0632 \\
\hline 15 & 14,577 & 19,083 & 33,660 & 6,978 & 1,0618 \\
\hline 16 & 15,016 & 19,819 & 34,835 & 7,431 & 1,0601 \\
\hline 17 & 15,440 & 21,001 & 36,441 & 7,915 & 1,0587 \\
\hline 18 & 15,852 & 22,013 & 37,865 & 8,331 & 1,0567 \\
\hline 19 & 16,251 & 22,819 & 39,070 & 8,661 & 1,0553 \\
\hline 20 & 16,639 & 23,433 & 40,072 & 8,912 & 1,0545 \\
\hline$\Sigma$ & 235,347 & 258,334 & 493,681 & & \\
\hline
\end{tabular}
$\left(\delta_{F}\right)$ de cada andar, no primeiro modo de vibração, obtidos com o Método Discreto, que estão condensados no quadro a seguir. 


\subsection{3- Verificação das Solicitações}

O acréscimo que o efeito dinâmico introduz nos deslocamentos da estrutura, se reflete também nas solicitações das barras. Evidentemente deve ser verificado se a estrutura suporta, e como suporta, este acréscimo nas solicitações.

Continuando a acompanhar o comportamento do pilar do eixo 2, da fila $B$, no quinto andar, observa-se que os dois processos introduzem majorações quase coincidentes porém, o método discreto é o mais severo. Portanto, considerando os seus efeitos, inclusive o momento de torção as solicitações no pilar em análise, devidas apenas às ações laterais serão:

$$
\begin{aligned}
& N \cong 780 \mathrm{kN} \\
& M_{X} \cong 41.885 \mathrm{kN} . \mathrm{cm}
\end{aligned}
$$

que somadas às solicitações causadas pelas ações verticais, resultam:

$$
\begin{aligned}
& \mathrm{Nd}=7.595 \mathrm{kN} \\
& M_{\mathrm{dx}}=47.305 \mathrm{kN} \cdot \mathrm{cm} \\
& \mathrm{M}_{\mathrm{dy}} \cong 0
\end{aligned}
$$

representando um acréscimo de $1,27 \%$ na solicitação normal e de $4,31 \%$ na de flexão. Entrando-se na segunda equação de iteração da NBR-8800 para verificar o estado limite último, considerando a estrutura como deslocável, encontra-se:

$$
\frac{N_{d}}{\phi_{C} N_{n}}+\frac{C_{m x} M_{d x}}{\left(1-\frac{N_{d}}{0,73 N_{e x}}\right) \phi_{b} M_{n x}}=1,042
$$

Com este valor, parece que a integridade do perfil não está comprometida.

Entretanto, na verificação dinâmica é tão ou mais importante o conforto dos usuários, que é um estado limite de utilização. Para isso, precisa-se determinar a aceleração máxima devida a resposta flutuante, pela expressão da NBR 6123 já citada no item 3.3.h, que é: 


$$
a=4 \pi^{2} f^{2} \delta
$$

Substituindo valores:

$a=4 \pi^{2} 0,4117^{2}(23,4 \times 8,912 / 40,1)=34,8 \mathrm{~cm} / \mathrm{s}^{2}=0,348 \mathrm{~m} / \mathrm{s}^{2}=3,55 \% \mathrm{~g}$

Portanto, movimento incômodo.

O gráfico de Chang, confirme este resultado, pois entrando-se com:

$$
\begin{aligned}
& T=1 / f=2,429 \mathrm{~s} \\
& \delta=5,2 \mathrm{~cm}
\end{aligned}
$$

retira-se: $a=3,5 \% \mathrm{~g}$ reiterando ser o movimento classificado como incômodo.

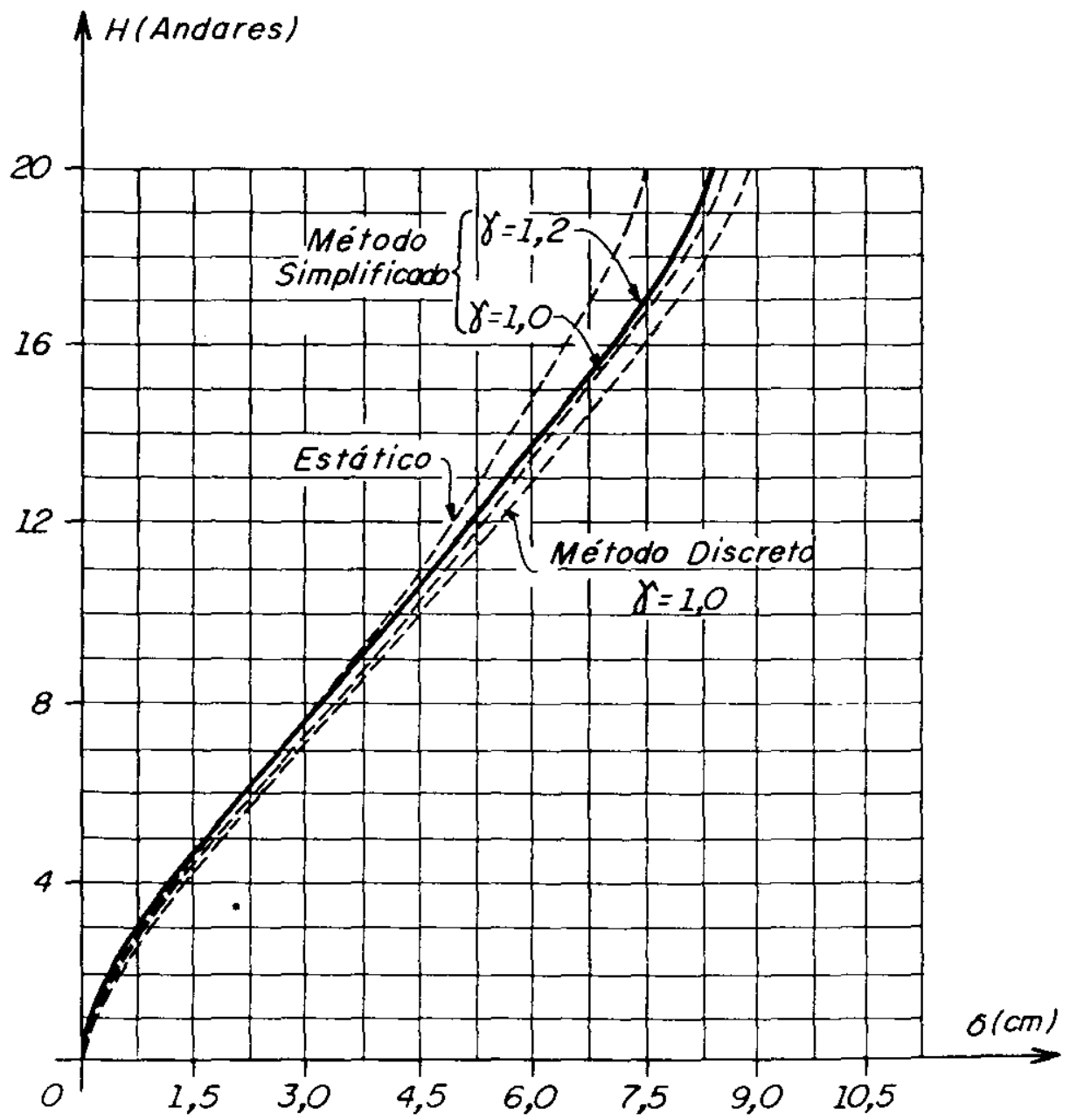

Figura 4.5 - Deslocamentos de Primeira e de Segunda Ordem 


\section{5- ANÁLISE COMPARATIVA}

\section{1- OS NÚCLEOS DE SERVIÇOS}

No capítulo anterior foi discutido o comportamento estrutural do sistema aporticado, sem atentar para as necessidades e exigências que costumam estar embutidas nos projetos de arquitetura e de serviços, que podem conduzir a algumas mudanças comportamentais.

Evidentemente, em um edifício com 20 andares e 900 metros de área constuída, em cada pavimento, considerando também as normalizações sobre proteção contra os incêndios, tornam-se necessárias algumas complementações ao projeto, tais como: no mínimo duas torres de escadas, dois conjuntos de elevadores, dependências sanitárias, copas, depósitos, local para subida e descida de água, esgoto, ar condicionado, fios, cabos de comando, etc.

Estas necessidades de espaço para circulação e administração podem, neste edifício exemplo, serem aglutinadas em dois conjuntos, simétricos, localizados no centro da edificação, entre as filas $B$ e $C$ e os eixos 1 a 3 e 4 a 6 , deixando o espaço entre os eixos 3 e 4 livre, para possibilitar a integração das duas áreas formadas ao longo destes núcleos de serviço.

Do ponto de vista estrutural a inclusão das paredes que vão formar os conjuntos de serviços, podem servir ou não, para o enrijecimento da estrutura, dependendo apenas do material a ser empregado na confecção destas paredes. Quando executadas em concreto armado, podem dar origem aos núcleos estruturais, que podem ou não, conter perfis metálicos na sua formação. Se executadas em alvenaria, ou outros materiais não estruturais, servem apenas de fechamento, de vedação e para dissimilar ou proteger contraventamentos metálicos, vigas mais robustas, ou outros artifícios estruturais utilizados para enrijecer a estrutura nestes pontos. 
A colocação destas paredes, mesmo quando não estruturais, não inviabiliza a utilização do sistema aporticado, bastando tão somente acrescer o seu peso aos já considerados. Este aumento do peso próprio da construção sobrecarrega a estrutura, principalmente as colunas e as vigas centrais, tornando necessário aumentar suas áreas e mesmo suas inércias.

Com o aumento na altura e na área dos perfis centrais, tanto das vigas como das colunas, é gerada uma concentração de rigidez junto ao centro da edificação, que também conduz a uma concentração de solicitações junto a estes perfis, que aliviam assim os prefis localizados fora destes núcleos.

Outro item que deve ser melhorado no sistema já estudado, refere-se à altura dos perfis que formam as colunas, que se possivel deve ser mantida constante ao longo da altura da edificação. Este cuidado visa mais a parte estética do que a resistência ou a estabilidade da mesma.

Quando a estrutura fica aparente é mais agradável visualmente, que todas as colunas tenham a mesma altura, o que facilita inciusive a execução das emendas dos perfis, que possuirão transição apenas nas espessuras das chapas que os formam.

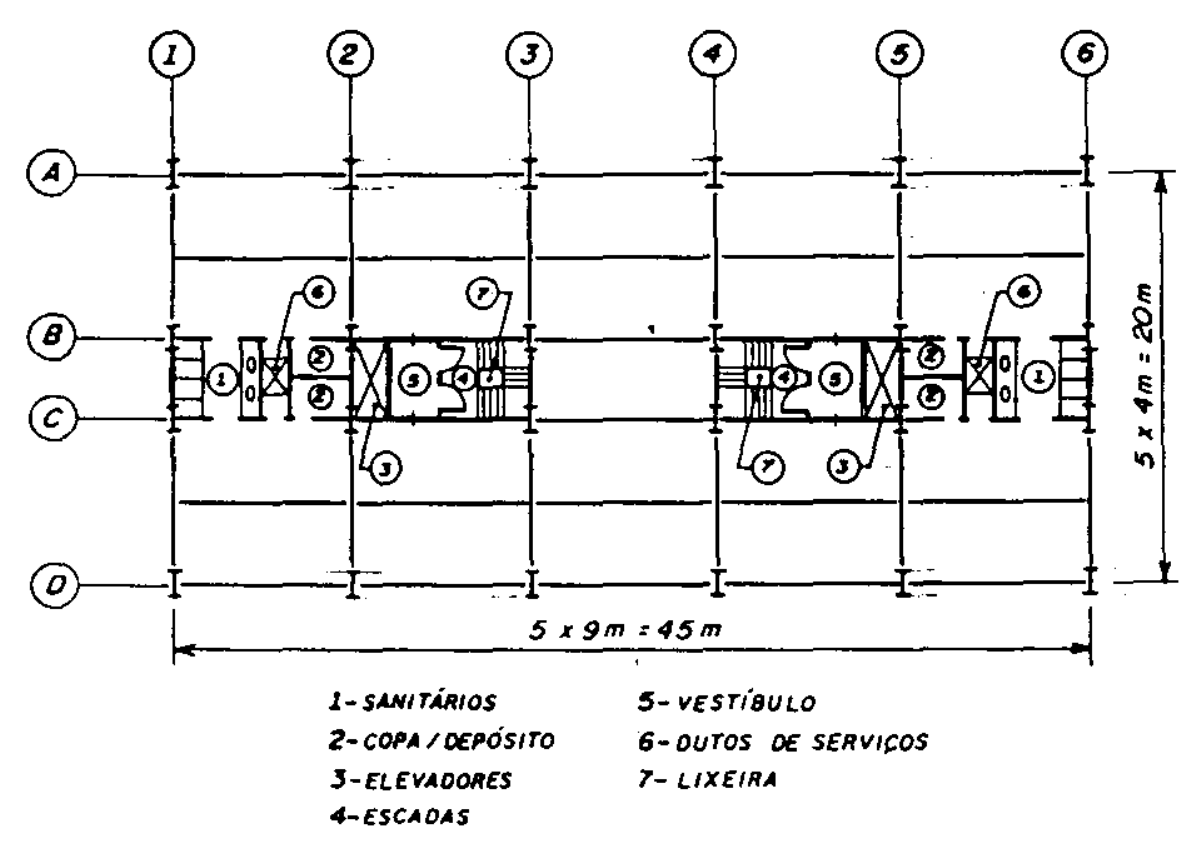

Figura 5.1 Pavimento Tipo - Aporticado

Para atender a estas colocações acaba sendo definida uma nova estrutura, diferente da que foi analisada, com colunas e vigas mais pesadas no centro e mais leves nas bordas e de altura constante. 
A altura dos perfis, agora constante, deve ser de tal ordem a não conduzir a grandes espessuras nas seções inferiores, nem a muito pequenas nas seções mais altas, que podem introduzir instabilidades nestas chapas. No sistema anterior, os perfis das colunas apresentam alturas diferentes, que variam de 900 a $550 \mathrm{~mm}$.

Para manter constante esta altura, é conveniente escolher um valor que se situe entre 700 e $800 \mathrm{~mm}$, visando manter as espessuras das chapas dentro dos padrões comerciais.

Adotando-se $700 \mathrm{~mm}$ como valor inicial, as espessuras das mesas dos perfis próximos ao solo, podem atingir e mesmo ultrapassar a $75 \mathrm{~mm}$, que é um valor bastante alto. Aumentando-se a altura para $800 \mathrm{~mm}$, verificase ser possivel manter a maior espessura limitada a $64 \mathrm{~mm}$, que foi a maior utilizada no modelo anterior.

Com esta altura e, após algumas iterações, chega-se a uma nova estrutura, ainda aporticada, com a mesma flexibilidade da estrutura anterior e com as colunas definidas com as seguintes seções:

\begin{tabular}{|c|c|c|c|}
\hline \multirow[t]{2}{*}{ LANCES } & PERFIS & ESCOLHIDOS & $(\mathrm{H} \times \mathrm{Peso} / \mathrm{m})$ \\
\hline & centrais & externas & vértices \\
\hline 10. & $800 \times 867$ & $800 \times 495$ & $800 \times 495$ \\
\hline 20. & $800 \times 718$ & $800 \times 406$ & $800 \times 406$ \\
\hline 30. & $800 \times 495$ & $800 \times 330$ & $800 \times 330$ \\
\hline 40. & $800 \times 330$ & $800 \times 254$ & $800 \times 254$ \\
\hline 50. & $800 \times 208$ & $800 \times 208$ & $800 \times 208$ \\
\hline
\end{tabular}

Quanto às vigas, nos pórticos que coincidem com a direção das filas, foi mantido o mesmo perfil utilizado no sistema aporticado, ou seja, perfis VS $500 \times 73$. Nos pórticos que coincidem com os eixos foi necessário empregar perfis VS $500 \times 97$ do primeiro até o sexto piso; perfis VS 500x86 do sétimo ao décimo quarto e perfis VS $500 \times 73$ nos demais, exceto na cobertura, onde foi mantido o perfil VS $500 \times 61$.

Definida a estrutura, pode ser determinado o seu consumo de aço, calculando-se inicialmente

$$
\begin{aligned}
\text { Peso total das vigas: } & =595 \mathrm{t} \\
\text { Peso total das colunas: } & =\underline{725 \mathrm{t}} \\
\text { Peso total: } & =1.320 \mathrm{t}
\end{aligned}
$$


Como a área construída é de $18.000 \mathrm{~m}^{2}$, chega-se ao consumo médio de $73,3 \mathrm{~kg} / \mathrm{m}^{2}$.

As colunas dos vértices ficaram com a mesma seção das colunas externas, pois embora as solicitações sejam menores, o seu comprimento de flambagem será maior, já que apenas uma viga concorre nos nós.

\subsection{1- Os Núcleos Metálicos}

Aproveitando o aumento da área e da inércia das colunas centrais, pode-se aumentar um pouco mais as vigas situadas entre estas colunas, de modo a aliviar ainda mais as vigas e as colunas externas, deixando-as quase que tão somente responsáveis pelas ações verticais.

Formam-se assim, pórticos de grande rigidez junto à região dos núcleos, que definem, nesta região, um comportamento diferenciado do resto da estrutura. Estes pórticos, os centrais, serão os únicos responsáveis pela absorção das ações horizontais.

Admitindo-se como válida esta hipótese, observa-se que as colunas externas podem ser dimensionadas considerando-as como indeslocáveis, o que aumenta em muito a sua resistência à compressão, uma vez que o seu comprimento de flambagem pode agora, ser tomado como igual ou mesmo menor que a unidade.

Quanto às vigas externas, estas podem agora ser consideradas como rotuladas nas colunas, entretanto, como já mostrado em capitulo anterior, rotular na prática é mais difícil que engastar.

Portanto pode-se, em princípio, considerar estas vigas como biengastadas, uma vez que sua inércia é muito menor que a inércia das colunas, sendo pequenas as alterações introduzidas por estes engastes no comportamento global da estrutura, uma vez que a parcela de momento que as mesmas devem absorver não é significativa, frente ao momento total que deve ser transmitido na ligação.

Com estas modificações, resulta uma estrutura semelhante à anterior, totalmente aporticada, porém com maior rigidez nas colunas e nas vigas centrais e colunas e vigas mais leves nos pórticos externos. 
Submetendo-se esta nova estrutura às mesmas açöes anteriores, é possivel determinar as seções ideais para as vigas e as colunas que, do mesmo modo que a estrutura anterior, terão todas a mesma altura nos prefis que as compōe.

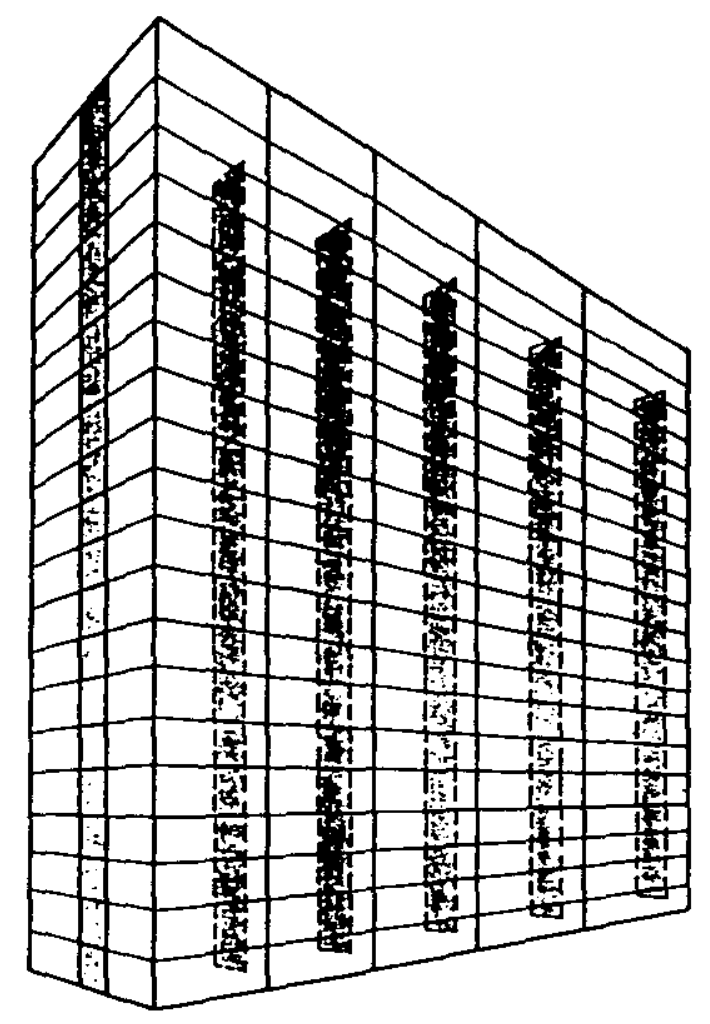

Figura 5.2 - Núcleo Metálico Aporticado

Otimizando-se esta nova estrutura, buscando um deslocamento no topo próximo do obtido no sistema anterior, confirma-se a estrutura com colunas e vigas mais esbeltas nos pórticos de contorno e bem mais pesadas nos pórticos centrais.

$\mathrm{Na}$ estrutura agora formada, os deslocamentos dos andares intermediários serão menores e apresentarão uma variação mais linear, confirmando que esta estrutura é mais deformável à flexāo que ao cortante, ou seja, possui um comportamento mais próximo ao de uma viga do que de um pórtico, como pode ser comprovado no gráfico dos deslocamentos, que é apresentado na figura 6.2 .

A disposição em planta não precisa ser alterada, como pode ser vista na figura seguinte, onde a única diferença a ser observada refere-se às dimensões das colunas, que são maiores nas filas centrais. 


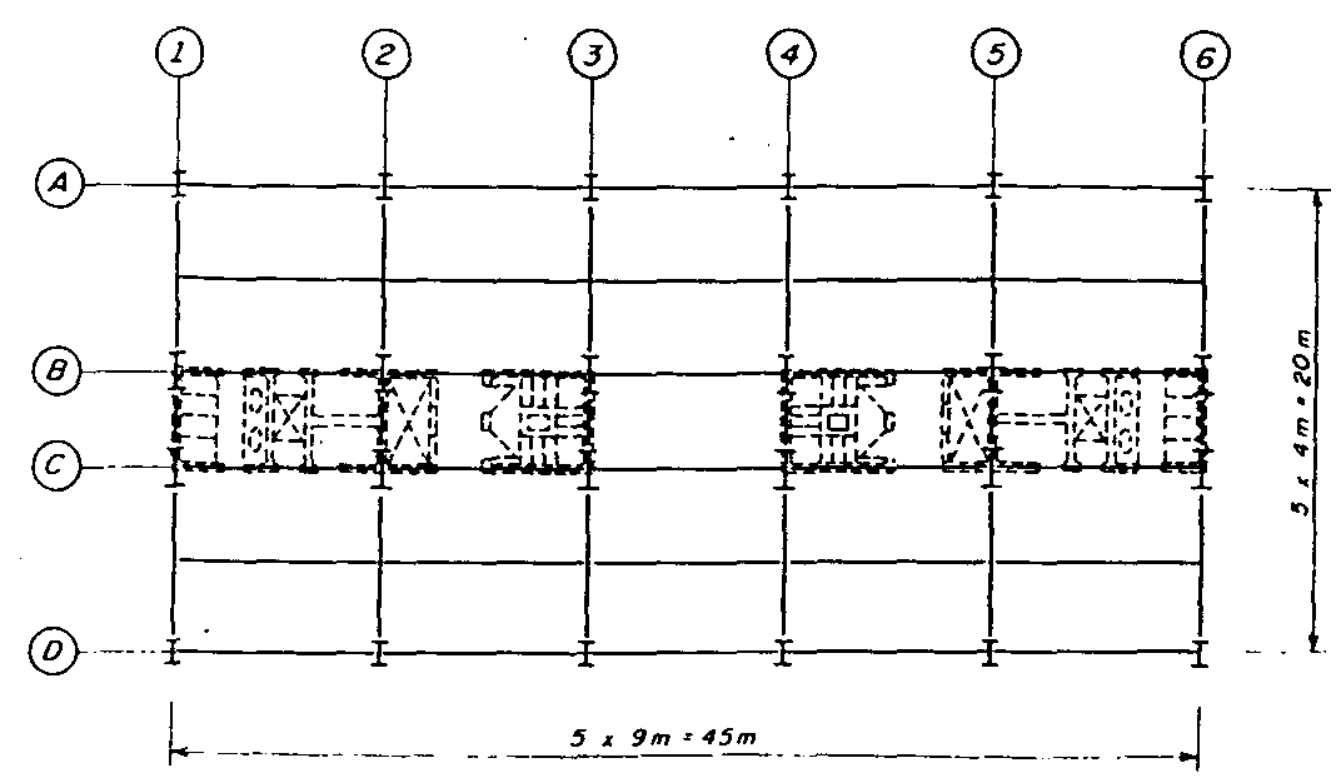

Figura 5.3 - Pavimento Tipo - Núcleo Metálico Aporticado

Deste modo, após as iterações necessárias à otimização da estrutura e compatibilização dos deslocamentos da cobertura, com os obtidos nas estruturas anteriores, chega-se aos seguintes perfis para as colunas:

\begin{tabular}{|c|c|c|c|}
\hline LANCES & PERFIS & ESCOLHIDOS & (HxPeso/m) \\
\hline & centrais & externas & vértices \\
\hline 10. & $1140 \times 1000$ & $400 \times 248$ & $400 \times 248$ \\
\hline 20. & $1140 \times 838$ & $400 \times 200$ & $400 \times 200$ \\
\hline 30. & $1140 \times 457$ & $400 \times 155$ & $400 \times 155$ \\
\hline 40. & $1140 \times 287$ & $400 \times 128$ & $400 \times 128$ \\
\hline 50. & $1140 \times 259$ & $400 \times 107$ & $400 \times 107$ \\
\hline
\end{tabular}

Para as vigas dos pisos, nos pórticos da direção das filas e as que formam os pórticos ña direção dos eixos (entre as filas $A$ e $B$ e $C$ e D), pode ser utilizado o perfil VS $500 \times 73$, enquanto que nestes pórticos, nas vigas centrais (entre as filas $B$ e C ) foi adotado o perfil CVS $1140 \times 259$, do primeiro ao último andar. Nas vigas que formam a cobertura foi mantido 0 perfil VS $500 \times 61$. 
Com estes perfis, o peso total de aço previsto para a estrutura é de:

$$
\begin{aligned}
& \text { Peso total das vigas: } \quad=618 \mathrm{t} \\
& \text { Peso total das colunas }=\underline{654 \mathrm{t}} \\
& \text { Peso total: }=1.272 \mathrm{t}
\end{aligned}
$$

que conduz a um consumo de $70,7 \mathrm{~kg} / \mathrm{m}^{2}$.

Uma outra maneira de garantir a eficiência do sistema, buscando um consumo menor de aço, consiste em contraventar as colunas centrais, transformando estes pórticos em treliças verticais contínuas, do térreo à cobertura.

As colunas que fazem parte da treliça e que continuam como as únicas responsáveis pelas ações horizontais, podem ser consideradas como indeslocáveis, o que, como já descrito, melhora a resistencia à compressāo, podendo portanto terem suas áreas e inércias reduzidas.

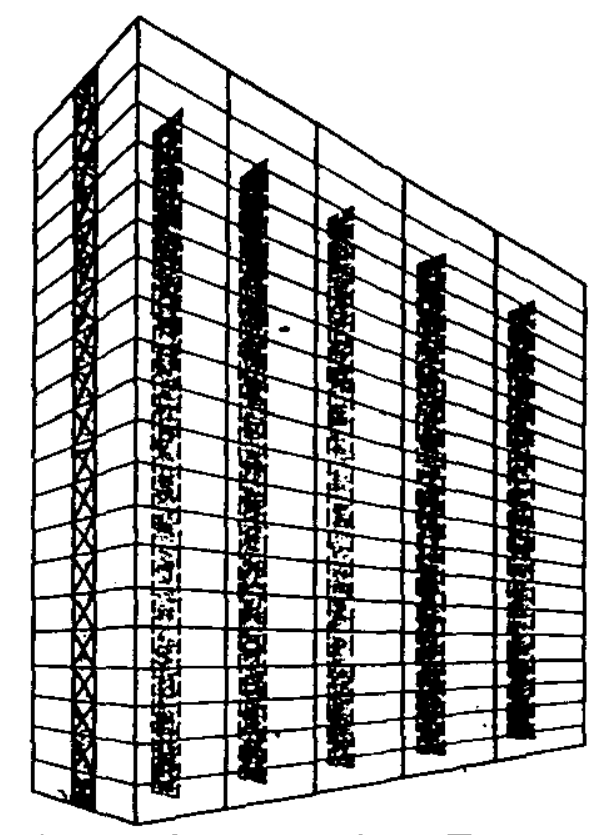

Figura 5.4 - Núcleo Metálico Treliçado

Portanto, com este sistema ocorre uma diminuição no peso dos perfis junto ao núcleo, entretanto, ocorre a inclusão dos perfis destinados às diagonais, o que não permite grandes oscilações no consumo de aço.

Este sistema define um gráfico de deslocamentos horizontais semeihante ao obtido para o sistema com núcleo aporticado, ou seja, um comportamento parecido com 0 de uma viga engastada em uma extremidade e livre na outra, como pode ser visto na figura 6.2 . 
Com estas premissas, após as iterações necessárias e destinadas à otimização da estrutura, chega-se aos seguintes perfis nas colunas:

\begin{tabular}{|c|c|c|c|}
\hline LANCES & PERFIS & ESCOLHIDOS & (HxPeso/m) \\
\hline & centrais & externas & vértices \\
\hline 10. & $1140 \times 838$ & $400 \times 264$ & $400 \times 248$ \\
\hline 20. & $1140 \times 630$ & $400 \times 200$ & $400 \times 200$ \\
\hline 30. & $1140 \times 398$ & $400 \times 155$ & $400 \times 155$ \\
\hline 40. & $1140 \times 287$ & $400 \times 128$ & $400 \times 128$ \\
\hline 50. & $1140 \times 259$ & $400 \times 107$ & $400 \times 107$ \\
\hline
\end{tabular}

Todas as vigas dos pisos podem ser fabricadas em perfis VS $500 \times 73$, as da cobertura em perfis VS 500x61, e as diagonais em perfis CS $300 \times 55$.

Deste modo o peso total de aço a ser usado na estrutura é de:

$$
\begin{aligned}
\text { Peso total das vigas: } & =565 \mathrm{t} \\
\text { Peso total das colunas: } & =548 \mathrm{t} \\
\text { Peso total das diagonais } & =\frac{70 \mathrm{t}}{\text { Peso total: }}=1.183 \mathrm{t}
\end{aligned}
$$

que conduz a um consumo médio de $65,7 \mathrm{~kg} / \mathrm{m}^{2}$.

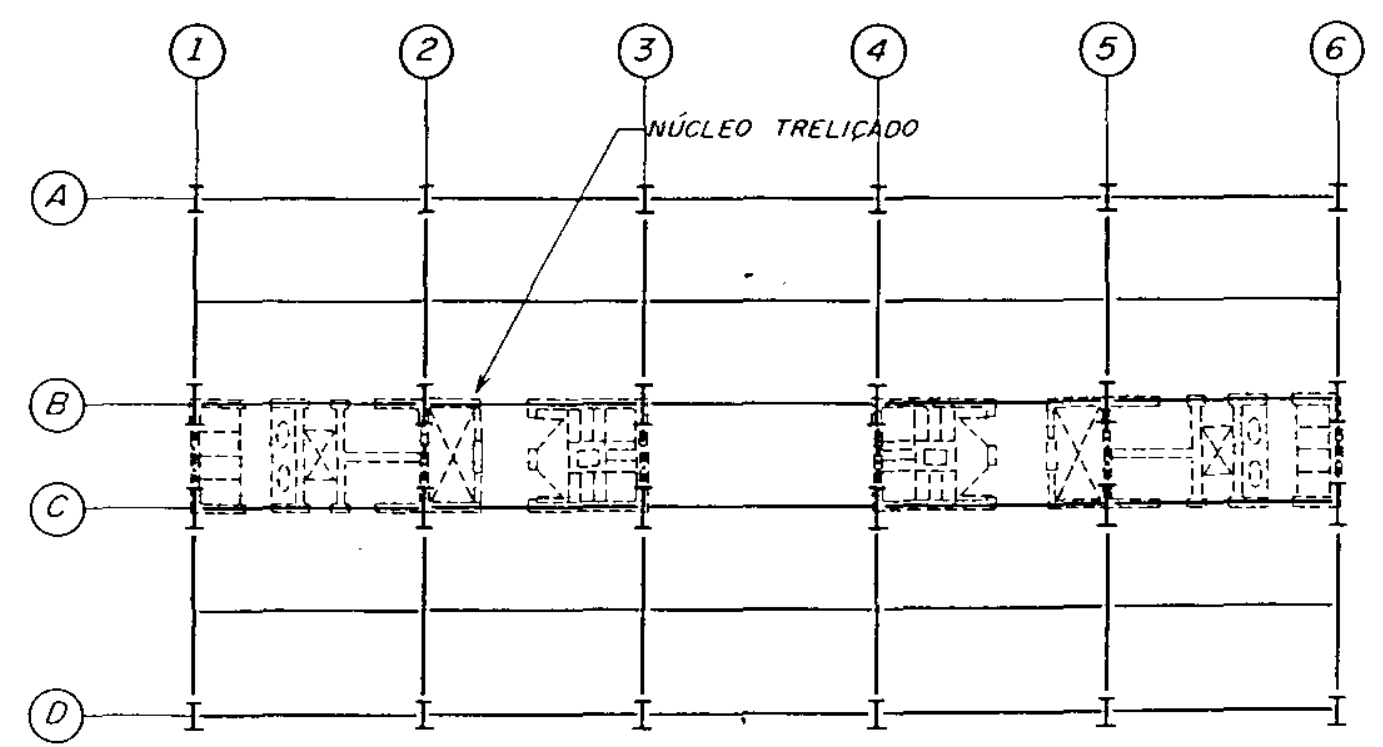

Figura 5.5 - Pavimento Tipo - Núcleo Metálico Treliçado. 


\subsection{2- Os Núcleos de Concreto}

Caso exista interesse, ou mesmo necessidade, todas as colunas centrais bem como as vigas metálicas, podem ser substituídas ou integradas às paredes de concreto, formando-se assim os núcleos de concreto armado quando as colunas e vigas centrais são removidas e os núcleos mistos quando as mesmas são integradas.

Estes sistemas possuem um comportamento estrutural semelhante ao sistema anterior, como pode ser observado no gráfico da figura 6.2.

Quanto ao consumo de aço, evidentemente neste é bem menor que nos outros, entretanto o consumo de concreto estrutural é muito maior, além de penalisar as fundaçōes, devido ao alto peso próprio do concreto das paredes que formam os núcleos estruturais.

Portanto, utilizando concreto armado na execução das paredes de serviço, é possível ligá-las às colunas e vigas metálicas, ou mesmo substituí-las.

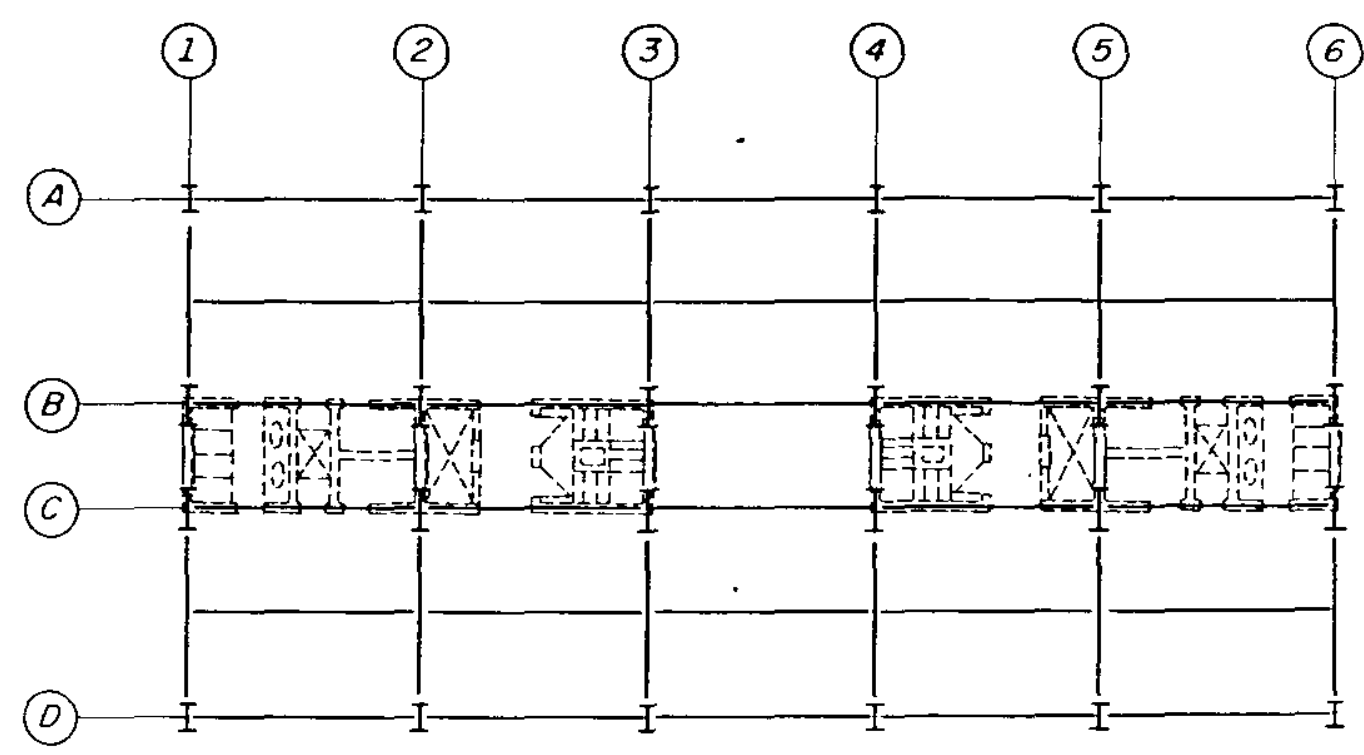

Figura 5.6 - Pavimento Tipo - Paredes Resistentes.

Incorporando inicialmente apenas as paredes que coincidem com os eixos obtém-se um comportamento um pouco mais diferenciado, uma vez que juntou-se o comportamento de pórtico com o de parede, porém mais rígido que o simplesmente aporticado. 
O aumento da rigidez, devido a incorporação das paredes de concreto, permite que sejam mantidas as colunas mais leves na periferia (filas $A$ e D) e mesmo nas vigas dos primeiros andares. Para reduzir o consumo de aço a um valor mínimo, pode-se incorporar também a rigidez das paredes pertencentes às filas $\mathrm{B}$ e $\mathrm{C}$.

Calibrando devidamente a espessura das paredes e as seções das colunas, chega-se a uma estrutura bastante competititva, em termos de consumo de aço, porém com uma alta utilização de concreto estrutural.

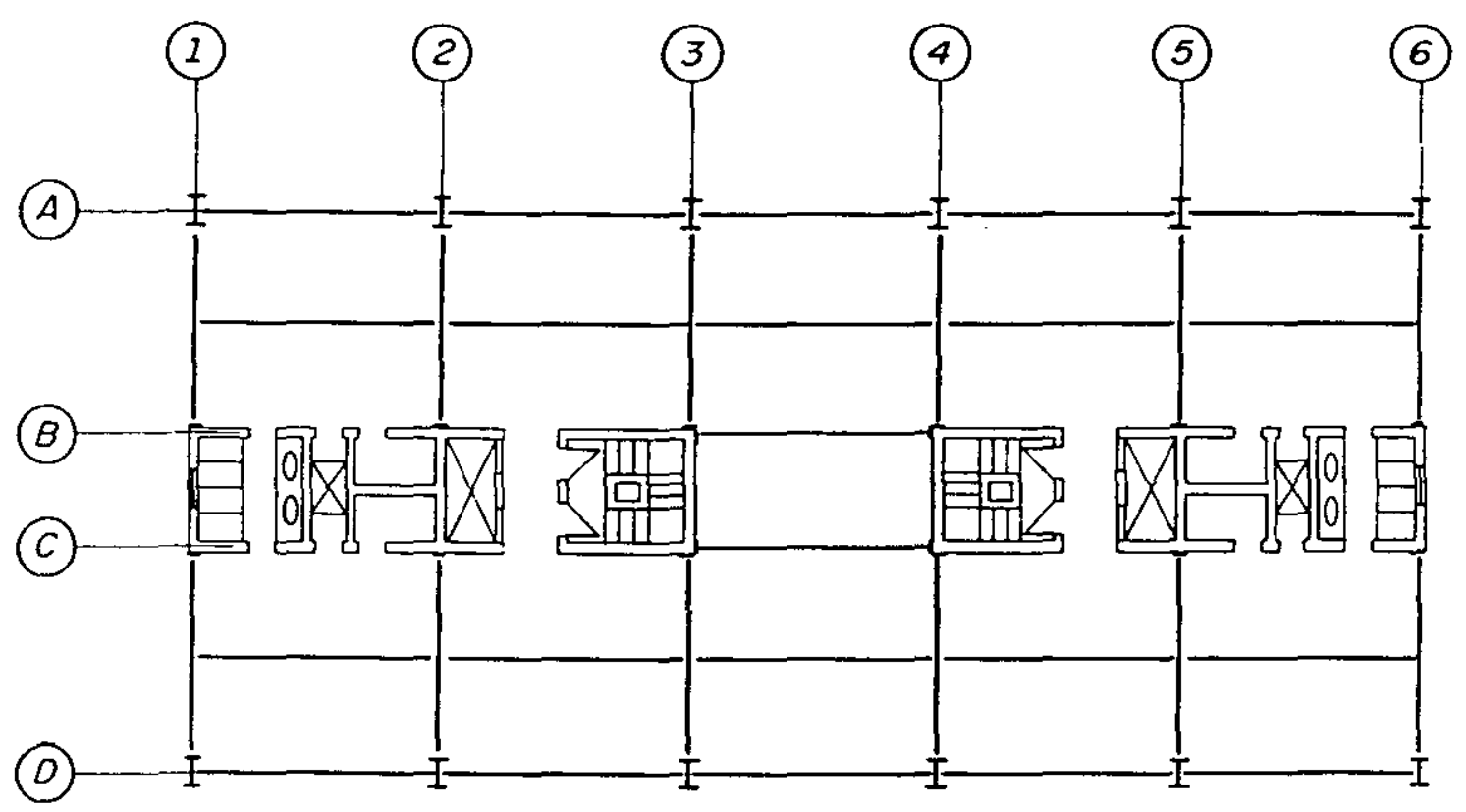

Figura 5.7 - Pavimento Tipo - Núcleo de Concreto

Considerando que existam colunas de aço apenas nas filas $A$ e $D$, solicitadas quase que tão somente pelas ações verticais e consideradas como indeslocáveis, uma vez que as açōes horizontais são absorvidas pelos núcleos de concreto, chegou-se aos seguintes perfis para as colunas, após as necessárias iterações:

\begin{tabular}{|c|c|c|c|c|c|}
\hline LANCES & 10. & 20 & 30 & 40. & 50. \\
\hline Externas & $400 \times 264$ & $400 \times 200$ & $400 \times 155$ & $400 \times 128$ & $400 \times 107$ \\
\hline Internas & $400 \times 248$ & $400 \times 200$ & $400 \times 155$ & $400 \times 128$ & $400 \times 107$ \\
\hline
\end{tabular}

As vigas em todos os pisos podem ser executadas com VS 500x73 e a cobertura em VS $500 \times 61$. 
Estes perfis conduzem ao seguinte peso total:

$\begin{aligned} \text { Peso total das vigas: } & =426 \mathrm{t} \\ \text { Peso total das colunas: } & \doteq 143 \mathrm{t} \\ \text { Peso total: } & =569 \mathrm{t}\end{aligned}$

que resulta em um consumo médio de apenas $32 \mathrm{~kg} / \mathrm{m}^{2}$.

Entretanto, o consumo de concreto estrutural pode chegar próximo de $1.100 \mathrm{~m}^{3}$, para uma redução de 750 toneladas de aço, aproximadamente, em relação ao sistema aporticado.

Aparentemente esta redução no consumo de aço pode significar uma economia no custo total da construção, porém aqui cabem algumas considerações sobre a aplicação de duas tecnologias construtivas tão diferentes entre sí.

A primeira consideração é sobre a utilização de melhorias e inovações tecnológicas, que ainda não é uma garantia de compatibiização das velocidades de execução destas duas modalidades construtivas, apenas de aumento do custo final da estrutura de concreto.
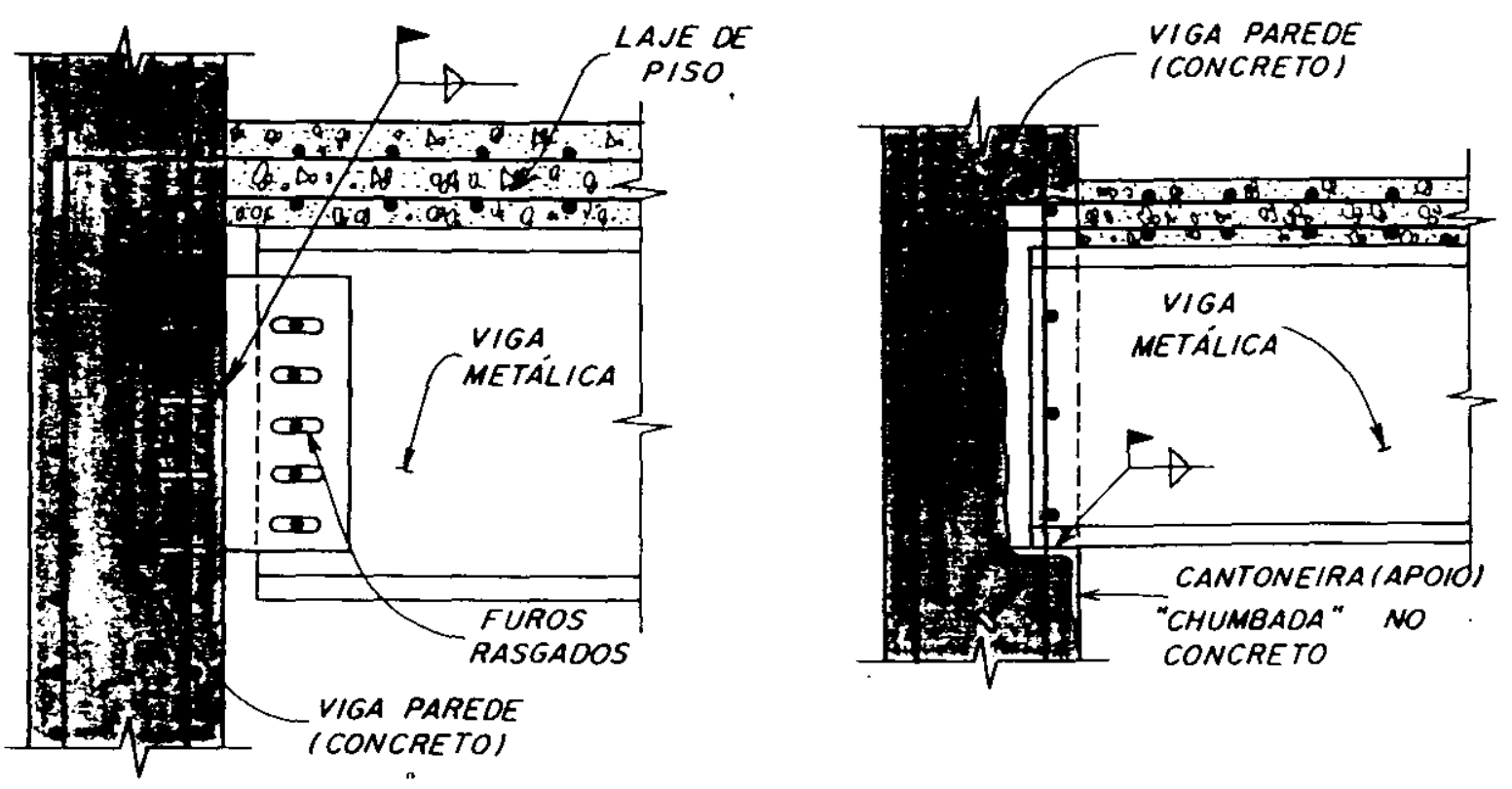

Figura 5.8 - Ligações Típicas Aço/Concreto

Outro inconveniente que existe na união destas tecnologias, é a precisão de fabricaçăo. 
Nas estruturas em aço é possível obter precisão da ordem de milimetros, enquanto que nas de concreto é dificil baixar a precisão da casa do centímetro.

Para conseguir esta compatibilização, mais uma vez lança-se mão de artificios construtivos, como furos rasgados, soldas de campo e uma elevada utilização de elementos metálicos como chumbadores e chapas de base, embutidas no concreto, para "ajustar" as duas estruturas nos seus pontos de contato.

Evidentemente, estes cuidados e a aplicação de inovações tecnológicas, elevam o custo final das estruturas, consumindo em alguns casos, a aparente economia conseguida com a redução do consumo de aço.

A construção dos núcleos em concreto possui uma velocidade de execução menor que a conseguida na montagem da estrutura metálica, mesmo utilizando formas deslizantes e conjugadas com processos de aceleração de cura, ainda assim o andamento da obra pode ser afetado.

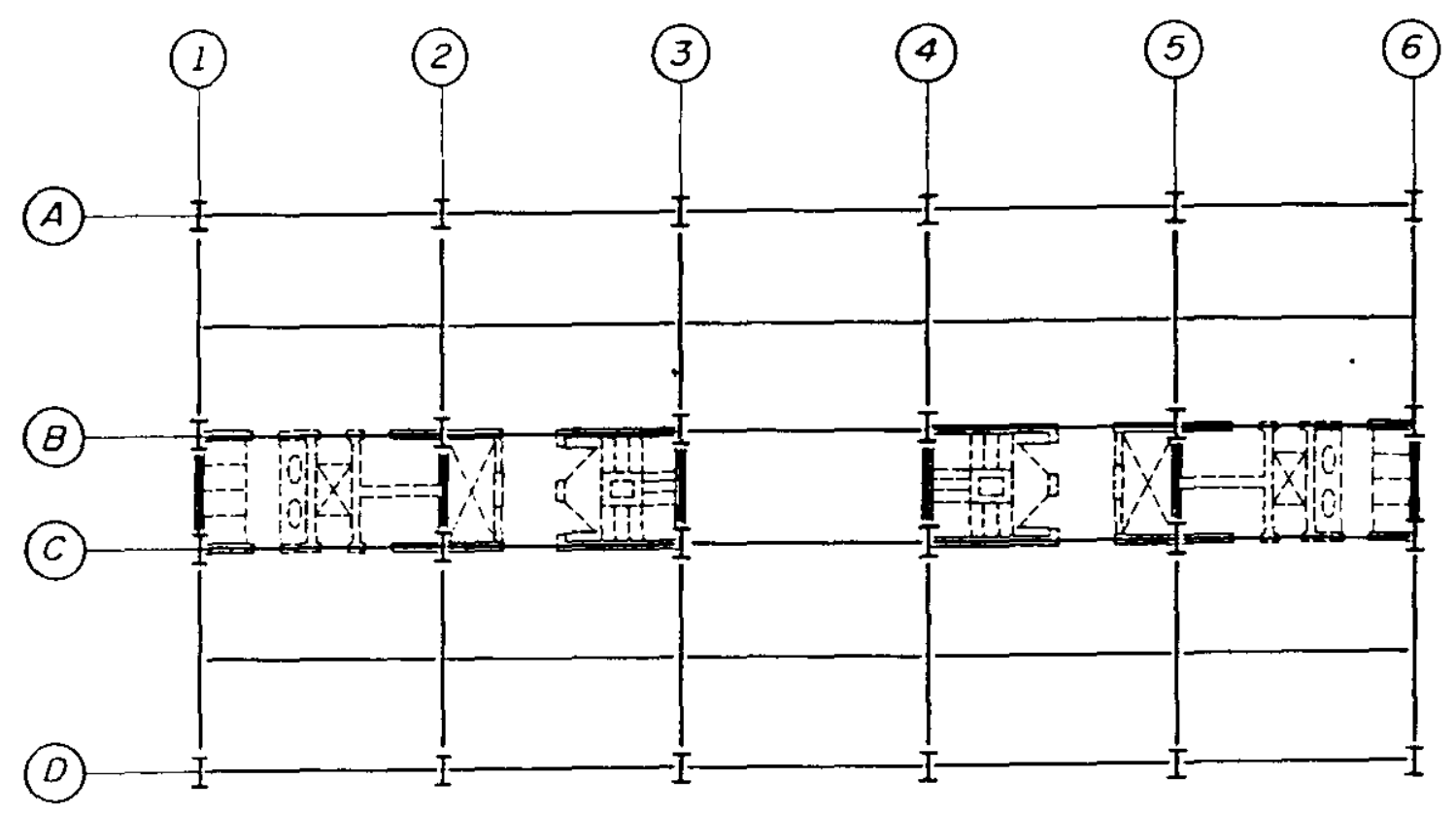

Figura 5.9 - Pavimento Tipo - Núcleo Misto

Para passar ao largo de toda esta confusão e evitar os prováveis atrasos do cronograma da obra, é possivel executar o núcleo estrutural misto aço/concreto, conciliando deste modo a montagem da estrutura de aço em paralelo com a execução das paredes de concreto. 
Nesta situaçăo, a estrutura de aço a ser incorporada ao núcleo é responsável, pela estabilidade global da obra e pelas ações que ocorrem durante a construção.

A estrutura mista, formada pela união do concreto já curado com os perfis metálicos, será responsável pelas ações que vão ocorrer ao longo da vida útil da estrutura. Em resumo, é a clássica divisão de ações consagradamente aplicadas às estrutruras mistas.

Evidentemente, este sistema consome mais aço que 0 anterior porém, consome menos concreto estrutural.
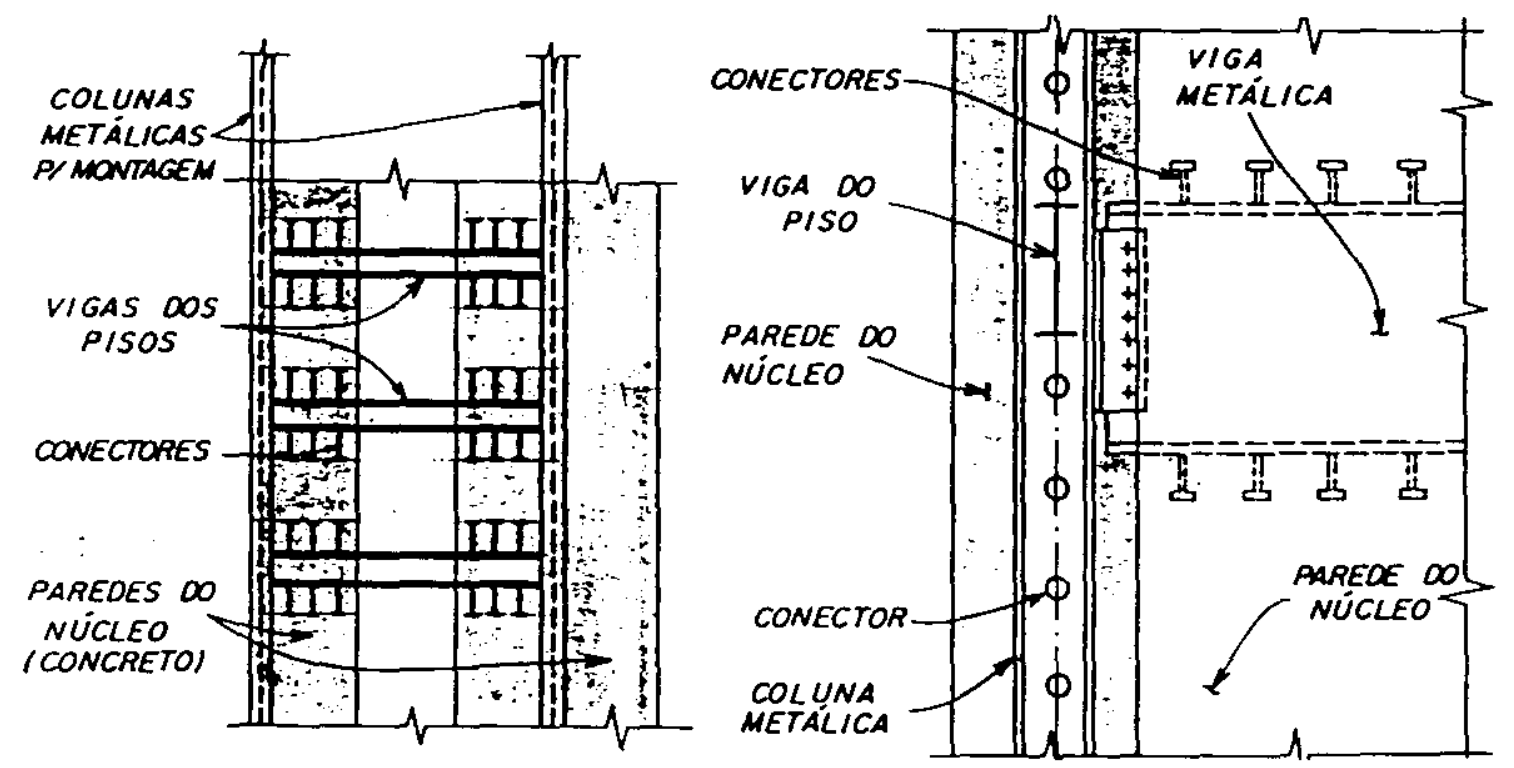

Figura 5.10 - Ligações Típicas de Núcleo Misto

Como forma de quantificar estas diferenças, pode-se adotar nas colunas e vigas do núcleo, os mesmos perfis utilizados no sistema anterior, e reduzir o volume de concreto até que a estrutura alcance a mesma rigidez da anterior.

Realizando estas modificações, e ajustando a estrutura assim formada chega-se ao̊s seguintes valores:

$$
\begin{aligned}
\text { Peso total das vigas: } & =565 \mathrm{t} \\
\text { Peso total das colunas } & =285 \mathrm{t} \\
\text { Peso total: } & =850 \mathrm{t}
\end{aligned}
$$


que representa um consumo de $47 \mathrm{~kg} / \mathrm{m}^{2}$, e o volume estimado de concreto a ser usado no núcleo é de apenas $180 \mathrm{~m}^{3}$.

Neste caso observa-se uma redução de quase $950 \mathrm{~m}^{3}$ de concreto estrutural, para um aumento de 281 tonèladas no consumo de aço.

\section{2- SISTEMAS TRELIÇADOS}

Para resistir às ações verticais, os sistemas aporticado e núcleo resistente, apresentam um desempenho altamente satisfatório, sendo inclusive auxiliados pela continuidade das vigas, que auxilia a concentração das reaçöes verticais junto ao miolo da edificação.

Entretanto, para as ações do vento, tais como o momento de tombamento e 0 de torção, as maiores reaçōes surgem nos pontos mais afastados do eixo geométrico ou elástico do sistema, contrariando o principio embutido nos sistemas anteriores, que é o de concentrar massa e consequentemente rigidez próximo a estes centros.

Uma maneira economica de distribuição de massa e de rigidez em um sistema, pode ser obtida atribuindo-se aos pórticos e aos núcleos eventualmente já formados, a responsabilidade das açōes verticais, criandose posteriormente treliças ao longo dos pórticos para resistirem às ações horizontais.

Este procedimento consiste basicamente em enrijecer, de maneira discreta ou contínua, os pórticos ou núcleos já criados.

Porém, a disposição destas treliças deve ser cuidadosa, para não prejudicar, ou mesmo inviabilizar a circulação e a ocupação dos pisos.

Portanto, treliçar continuamente todos os pórticos pode parecer a melhor solução estrutural, porém é a pior do ponto de vista da ocupação da edificação.

Criar treliças em andares alternados, concilia os dois objetivos, com ganhos e perdas generalizados, pois enquanto um andar fica totalmente livre, o outro possuirá obstáculos no plano de cada pórtico, e sob o ponto de vista estrutural os andares treliçados serão indeslocáveis, porém os não treliçados, por serem deslocáveis, ficam na dependência da rigidez solitária das colunas para garantir sua estabilidade. 
Este sistema de treliçamento foi pouco empregado, e mesmo assim para construções com poucos andares.

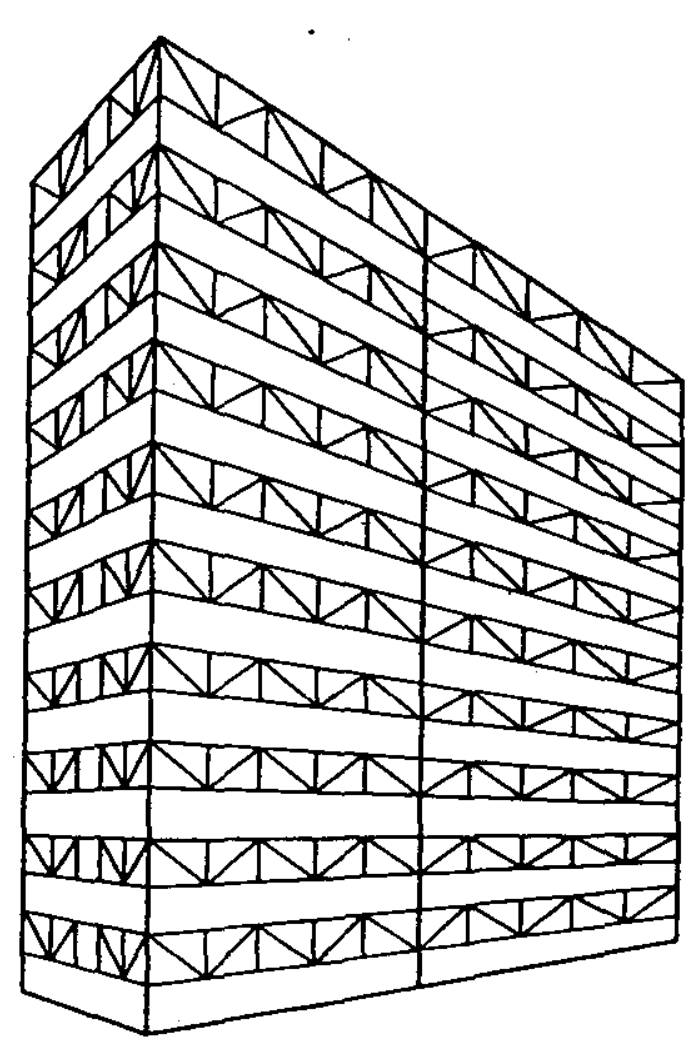

Figura 5.11 - Treliças Alternadas

Para construções mais altas, como a em estudo neste trabalho, podem ser criadas treliças verticais contínuas, dispostas nos vãos que já possuem obstáculos naturais à circulação como paredes de núcleos de serviços e treliças também contínuas porém horizontais, no número mínimo necessário para adequar a flexibilidade da construçāo ao padrão desejado, ou mesmo solicitado pela normalização técnica.

A este sistema, chamado por alguns autores [ 33,38$]$ de "Outrigger", é atribuido a possibilidade da execução de diversos edifícios com grande relação altura/largura.

A quantidade e a localização das treliças horizontais já foram bastantes estudadas e os resultados convergem para a colocação de apenas duas terliças, uma quase no topo da edificação e outra próxima do meio da altura. Evidentemente, nos andares que possuem treliças horizontais, a circulação será extremamente prejudicada, ou então ocorrerá uma drástica redução na área utilizável. 
Os deslocamentos horizontais deste sistema, que estāo mostrados no gráfico da figura 6.2, ilustram o comportamento estrutural deste sistema que é muito semelhante ao do núcleo de aço, exceto nos andares que contam com a presença das treliças horizontais, onde podem ser observados os efeitos das mesmas nos respectivos deslocamentos.

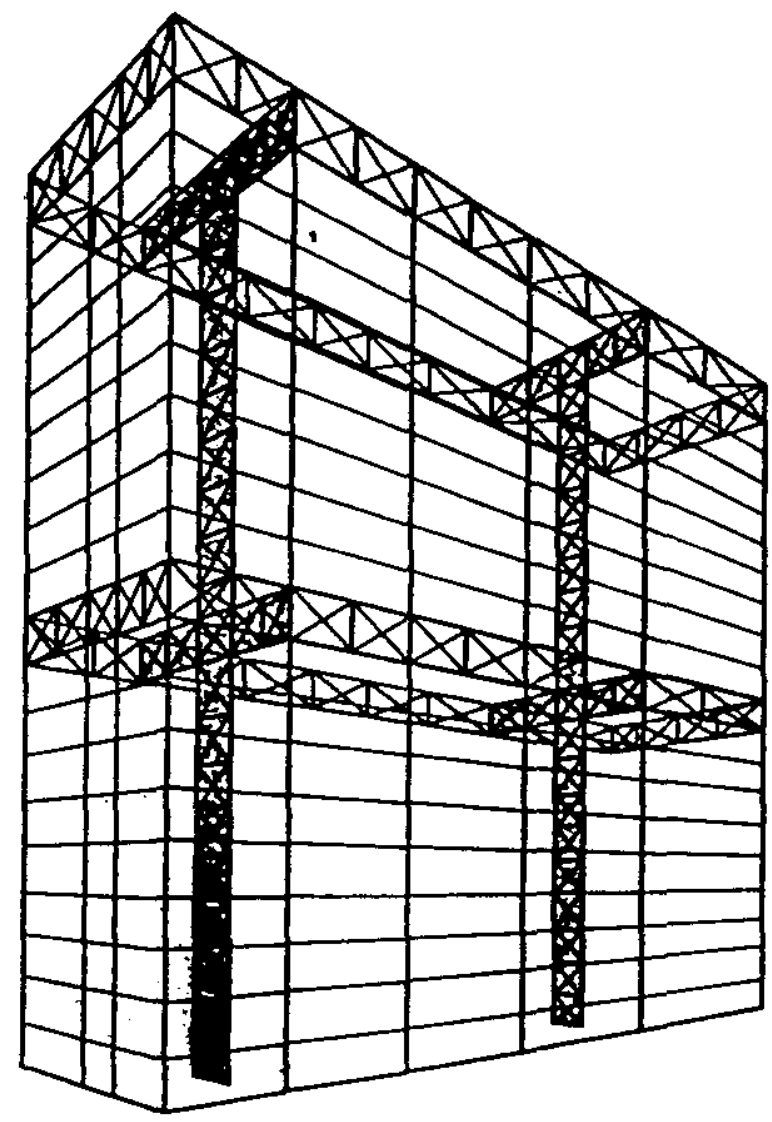

Figura 5.12 - Treliças Conjugadas

Para este sistema, após as necessárias iteraçōes para otimização da estrutura, chegou-se aos seguintes perfis nas colunas:

\begin{tabular}{|c|c|c|c|}
\hline LANCES & PERFIS & ESCOLHIDOS & (HxPeso/m) \\
\hline & centrais & externas & vértices \\
\hline 10 & $\therefore 800 \times 563$ & $400 \times 316$ & $400 \times 248$ \\
\hline 20. & $800 \times 495$ & $400 \times 248$ & $400 \times 200$ \\
\hline 30. & $800 \times 330$ & $400 \times 200$ & $400 \times 155$ \\
\hline 40. & $800 \times 254$ & $400 \times 128$ & $400 \times 128$ \\
\hline 50. & $800 \times 208$ & $400 \times 107$ & $400 \times 107$ \\
\hline
\end{tabular}


Nas vigas dos pisos pode ser empregado o perfil VS $500 \times 73$ e na cobertura o perfil VS $500 \times 61$; nas diagonais o perfil CS $250 \times 52$.

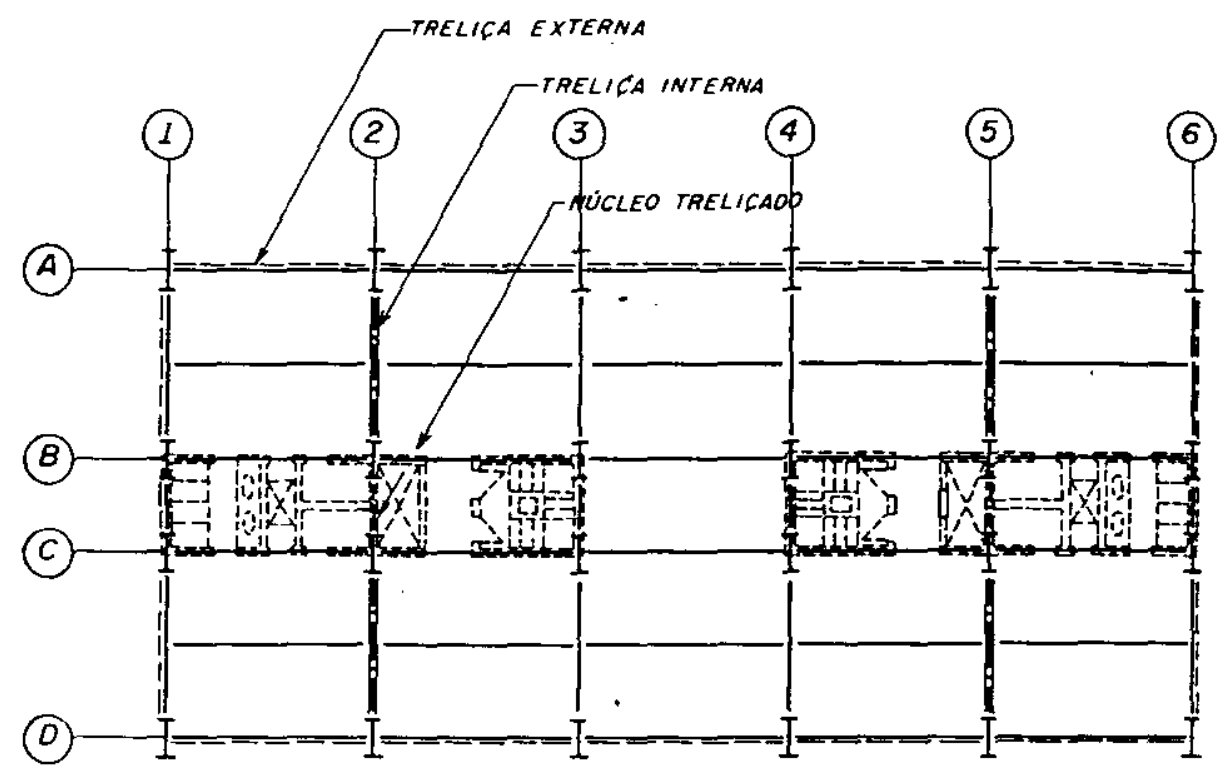

Figura 5.13 - Pavimento com Treliças Conjugadas

Estes perfis apontam para uma tonelagem total de:

\begin{tabular}{|c|c|c|}
\hline Vigas dos pisos: & $=$ & \\
\hline Colunas: & $=$ & \\
\hline Diagonaiis: & & \\
\hline & & \\
\hline
\end{tabular}

que conduz a um consumo de $63 \mathrm{~kg} / \mathrm{m}^{2}$, praticamente igual ao obtido no sistema de núcleo treliçado, já que este sistema nada mais é do que uma variação daquele.

\section{3- SISTEMAS TUBULARES}

Visando exatamente a absorção das ações introduzidas pelo momento de torção devido à açāo do vento e em escala menor, também as do momento de tombamento, é que foi desenvolvido este sistema, que consiste, basicamente, em concentrar as colunas do contorno da edificação, dispostas com o eixo de maior inércia no sentido do pórtico, deixando-as quase que tão somente, as responsáveis pelas ações horizontais. 
Para melhorar o comportamento do sistema assim formado, quase como uma consequência natural da concentração de material e de rigidez na periferia da edificação, as vigas ao nível dos andares necessitam ter inércia maior que as demais vigas dos andares, e as colunas, também para melhorar a eficiência do sistema, costumam ter seu número aumentado, gerando uma concentração cada vez maior de material nesta região.

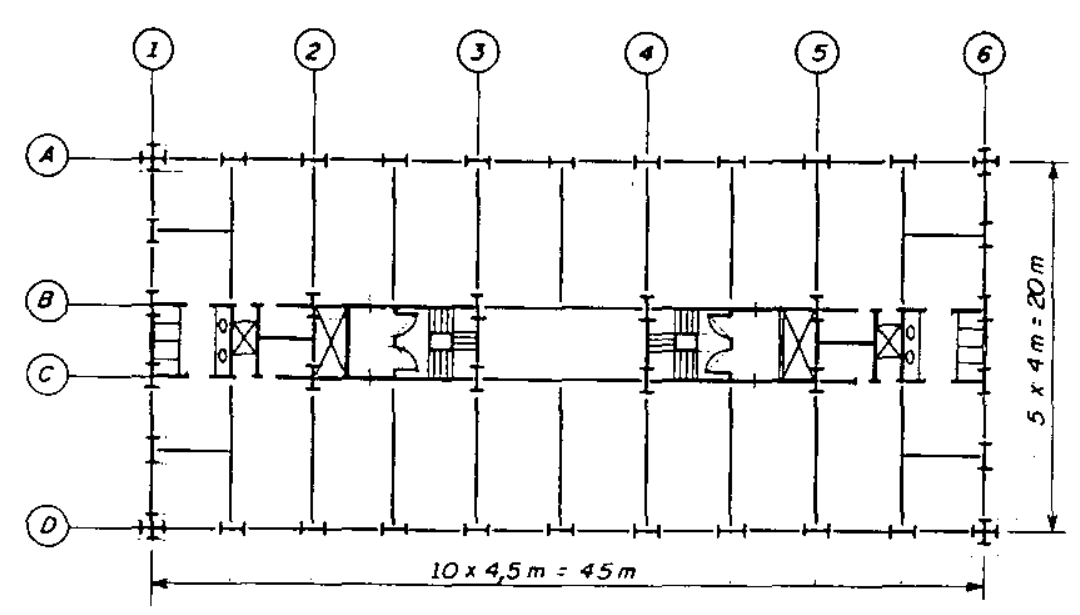

Figura 5.14 - Pavimento Tipo - Sistema Tubular

Este sistema estrutural possui assim, um comportamento muito semelhante ao de um tubo de paredes finais, dai o nome que identifica $o$ sistema.

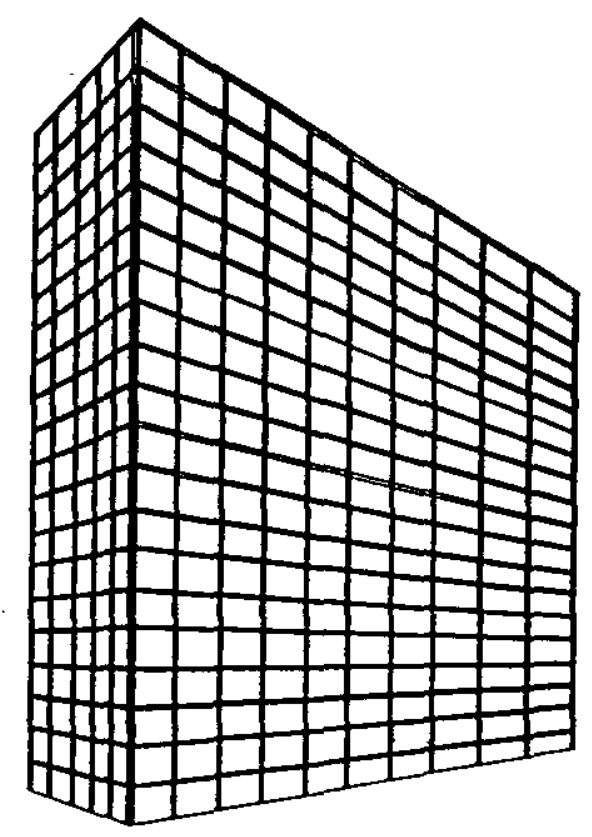

Figura 5.15 - Tubular Aporticado 
O sistema descrito, pode ser denominado de tubular aporticado ou "vierendeel", uma vez que os pórticos externos podem ser identificados como treliças sem as barras inclinadas, ou seja as diagonais, que recebe esta denominação particular.

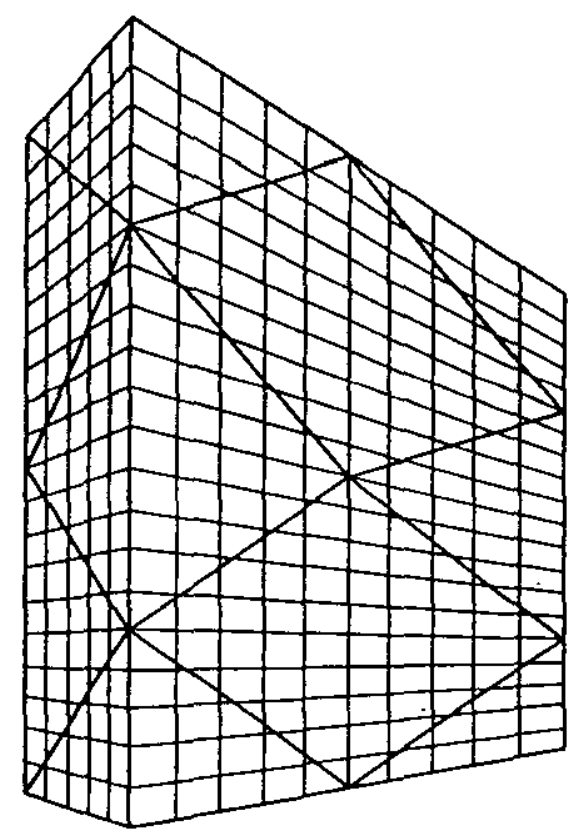

Figura 5.16 - Tubular Treliçado

Uma outra maneira de obter este mesmo comportamento, consiste em criar treliças completas nestes planos, incluindo também as diagonais, dando origem ao sistema tubular treliçado.

No caso da edificação em análise, os deslocamentos obtidos para os dois tipos de sistema não apresentam diferenças significativas, uma vez que a continuidade e a concentração de massa dos dois sistemas induz um comportamento muito semelhante ao de uma viga parede.

No sistema aporticado, após algumas iterações chegou-se aos seguintes perfis para as colunas:

\begin{tabular}{|c|c|c|c|}
\hline LANCES & PERFIS & ESCOLHIDOS & (HxPeso/m) \\
\hline & vértices & externas & centrais \\
\hline 10 & $700 \times 556$ & $700 \times 278$ & $800 \times 462$ \\
\hline 20. & $700 \times 406$ & $700 \times 203$ & $800 \times 347$ \\
\hline 30. & $700 \times 332$ & $700 \times 166$ & $600 \times 230$ \\
\hline 40. & $700 \times 332$ & $700 \times 166$ & $550 \times 169$ \\
\hline 50. & $700 \times 258$ & $700 \times 129$ & $400 \times 107$ \\
\hline
\end{tabular}


Nas vigas dos pórticos externos, nos eixos 1 e 6 foi utilizado o perfil CVS $700 \times 166$ e, nas filas A e D o perfil CVS 700x129. Nas vigas internas

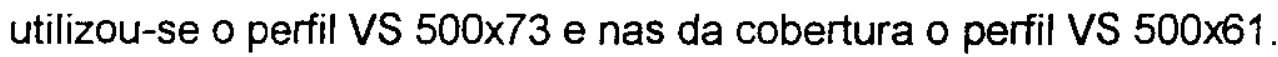

Deste modo, chega-se ao seguintè peso de aço na estrutura:

$$
\begin{aligned}
\text { Nas Vigas: } & =782 \mathrm{t} \\
\text { Nas Colunas: } & =\underline{596 \mathrm{t}} \\
\text { Total: } & =1.378 \mathrm{t}
\end{aligned}
$$

que conduz a um consumo de $76,6 \mathrm{~kg} / \mathrm{m}^{2}$.

No cálculo anterior foram incluidas as vigas e colunas que sustentam as paredes dos núcleos. Caso o núcleo fosse em concreto armado, o consumo de aço cairia para 1074 toneladas ou $59,7 \mathrm{~kg} / \mathrm{m}^{2}$.

\begin{tabular}{|c|c|c|c|}
\hline LANCES & PERFIS & ESCOLHIDOS & (HxPeso/m) \\
\hline & vértices & externas & centrais \\
\hline 10 & $700 \times 406$ & $700 \times 203$ & $800 \times 462$ \\
\hline 20. & $700 \times 332$ & $700 \times 166$ & $800 \times 347$ \\
\hline 30. & $700 \times 258$ & $700 \times 129$ & $600 \times 230$ \\
\hline 40. & $700 \times 258$ & $700 \times 129$ & $550 \times 169$ \\
\hline 50. & $700 \times 258$ & $700 \times 129$ & $400 \times 107$ \\
\hline
\end{tabular}

No sistema treliçado, devido a condição indeslocável das colunas, chega-se aos perfis:

As vigas dos pisos voltam a ser em perfis VS $500 \times 73$ e, na cobertura em perfis VS $500 \times 61$. As diagonais, independentes do seu esquema, podem ser em perfis CS $250 \times 52$ e finalmente chega-se ao peso total a ser utilizado:

$$
\begin{aligned}
& \text { Nas colunas: } \quad=\quad 507 \mathrm{t} \\
& \text { Nas vigås: } \quad=605 \mathrm{t} \\
& \text { Nas diagonais: } \quad=\quad 35 \mathrm{t} \\
& \text { Total de } \quad=1147 \mathrm{t}
\end{aligned}
$$

que conduz a um consumo de $63,7 \mathrm{~kg} / \mathrm{m}^{2}$. 
Também neste caso foram incluídos as vigas e as colunas centrais que, caso substituídas pelas paredes de concreto, reduziriam o consumo de aço a 845 toneladas, ou $46,9 \mathrm{~kg} / \mathrm{m}^{2}$. Os deslocamentos destes dois sistemas estão mostrados na figura 6.2 :

\section{4- CRITÉRIOS UTILIZADOS PARA OTIMIZAÇÃO}

Nos itens anteriores foram apresentados e discutidos alguns sistemas estruturais, escolhidos entre os mais conhecidos ou já utilizados que, após serem submetidos a alguns critérios de carregamento e de dimensionamento, permitiram a determinação do consumo de aço em cada um deles.

Como critérios de carregamento foram aplicadas as ações de peso próprio, incluindo-se o peso das paredes dos núcleos de serviço, estruturais ou não; a ação global do vento, com incidencia apenas na face maior, sem excentricidade devido a efeitos de vizinhança.

Como já realizado e discutido em capítulo anterior, esta ação foi dividida entre os pórticos que formam as estruturas, proporcionalmente à rigidez de cada um, gerando-se assim forças de intensidades diferentes para cada estrutura.

Quanto ao fato de não ter sido considerado o momento de torção, motivado pela excentricidade da força global, como pode ser verificado no capítulo anterior, sua consideração majora, em muito, os deslocamentos horizontais, porém não aumenta consideravelmente as tensões nas barras.

Deste modo, limitando-se os deslocamentos aos valores obtidos no capítulo anterior, antes de superpor o referido momento de torção, ficam as estruturas com uma reserva de flexibilidade suficiente para não ultrapassarem os valores recomendados, caso o mesmo fosse considerado.

Quanto às teñsões nas barras procurou-se limitá-las a no náximo $90 \%$ da capacidade de cada uma, permitindo-se em alguns poucos casos 0 indice de $100 \%$.

As deformaçōes da estrutura foram obtidas com os valores nominais das ações, uma vez que se trata de um estado limite de utilização. 
As solicitações nominais foram transformadas em solicitações de cálculo, mediante a aplicação dos coeficientes de majoração fornecidos pelo NBR-8800.

$\mathrm{Na}$ ação de sobrecarga, considerada como ação variável secundária, foi utilizado o valor unitário para o fator de combinação, entretanto empregou-se as reduçōes preconizadas na NBR-6120, que permitiu considerar apenas 0,52 da ação total nos pilares do primeiro andar; nos pilares do quinto andar 0,$55 ; 0,60$ nos do nono andar; 0,7 nos do décimo terceiro e finalmente 0,95 no décimo sétimo, uma vez que foi mantida a variação das seções a cada quatro pavimentos.

Os coeficientes de ponderação aplicados às solicitações foram os mesmos já discutidos, ou seja:

$$
\mathrm{C}=1,4 \mathrm{P}_{\mathrm{p}}+1,5 \mathrm{~S}_{\mathrm{c}}+1,4 \mathrm{~W}
$$

Apenas para ilustrar a variação que ocorre nos deslocamentos horizontais, é acrescentado a seguir o quadro resumo destes deslocamentos considerando os sistemas estruturais analizados, com a notação:

$$
\begin{aligned}
& a=\text { Aporticado } \\
& b=\text { Núcleo Aço/Concreto } \\
& c=\text { Núcleo de Aço Aporticado } \\
& d=\text { Núcleos de Concreto } \\
& e=\text { Treliças Conjugadas ou "Outrigger" } \\
& f=\text { Tubulares }
\end{aligned}
$$




\begin{tabular}{|c|c|c|c|c|c|c|c|}
\hline \multirow[t]{2}{*}{ ANDARES } & \multicolumn{7}{|c|}{ SISTEMAS ESTRUTURAIS ANALISADOS } \\
\hline & a & b & $\mathrm{c}$ & d & $f$ & $\mathrm{~g}$ & $\mathrm{~h}$ \\
\hline 1 & 0,149 & 0,103 & 0,092 & 0,044 & 0,158 & 0,240 & 0,240 \\
\hline 2 & 0,484 & 0,333 & 0,290 & 0,163 & 0,466 & 0,574 & 0,574 \\
\hline 3 & 0,903 & 0,632 & 0.549 & 0,348 & 0,842 & 0,928 & 0,928 \\
\hline 4 & 1,361 & 0,974 & 0,852 & 0,591 & 1,264 & 1,303 & 1,303 \\
\hline 5 & 1,836 & 1.350 & 1.194 & 0,885 & 1,728 & 1,730 & 1,730 \\
\hline 6 & 2,315 & 1.750 & 1.570 & 1.221 & 2,219 & 2,160 & 2,160 \\
\hline 7 & 2,797 & 2.167 & 1.973 & 1.593 & 2,719 & 2,574 & 2,574 \\
\hline 8 & 3.276 & 2.596 & 2.396 & 1.994 & 3,218 & 2,981 & 2.980 \\
\hline 9 & 3.749 & 3.043 & 2.837 & 2.420 & 3,668 & 3,426 & 3,426 \\
\hline 10 & 4,202 & 3.500 & 3,298 & 2.864 & 3,800 & 3,911 & 3,910 \\
\hline 11 & 4,635 & 3.960 & 3.764 & 3,322 & 4.238 & 4,373 & 4,373 \\
\hline 12 & 5.045 & 4.418 & 4.232 & 3.791 & 4,719 & 4,800 & 4,800 \\
\hline 13 & 5,439 & 4.878 & 4.700 & 4,267 & 5.206 & 5,209 & 5,209 \\
\hline 14 & 5,813 & 5.327 & 5.159 & 4,746 & 5,685 & 5,613 & 5,613 \\
\hline 15 & 6,185 & 5.761 & 5.606 & 5,228 & 6,148 & 6,012 & 6,012 \\
\hline 16 & 6,553 & 6.117 & 6.039 & 5,709 & 6,586 & 6,388 & 6,388 \\
\hline 17 & 6,892 & 6.575 & 6.039 & 6,189 & 6,990 & 6,729 & 6,729 \\
\hline 18 & 7.185 & 6.950 & 6.852 & 6.667 & 7,353 & 7,039 & 7,039 \\
\hline 19 & 7,431 & 7.304 & 7.235 & 7.144 & 7,665 & 7,327 & 7,327 \\
\hline 20 & 7.658 & 7.638 & 7.597 & 7.614 & 7,822 & 7,598 & 7,598 \\
\hline
\end{tabular}

Ainda para permitir uma visualização das alterações que podem ocorrer na resistência de um mesmo perfil, quando modifica-se a sua condição de deslocável ou indeslocável, são crescentadas a seguir as planilhas com os resumos das composições dos perfis utilizados na iteração final, com suas principais propriedades geométricas e resistências de cálculo à compressão, considerando estas duas condições, sendo que para a condiçăo indeslocável, foi utilizado o ábaco da NBR-8800, anexo I, na determinação do fator de correção do comprimento de flambagem. 
Perfis com altura de $400 \mathrm{~mm}$

\begin{tabular}{|c|c|c|c|c|c|c|}
\hline $\begin{array}{c}P \\
(\mathrm{~kg} / \mathrm{m}) \\
\end{array}$ & $\begin{array}{c}A \\
\left(\mathrm{~cm}^{2}\right) \\
\end{array}$ & $\begin{array}{c}\text { COMPOSI- } \\
\text { ÇĀO }\end{array}$ & $\begin{array}{l}1 x / l y \\
(\mathrm{~cm} 4) \\
\end{array}$ & $\begin{array}{c}\text { iy } \\
(\mathrm{cm})\end{array}$ & Ky & $\begin{array}{l}\phi \mathrm{cNn} \\
(\mathrm{kN}) \\
\end{array}$ \\
\hline 574 & 476 & $\begin{array}{r}45 \times 400 \\
37,5 \times 310 \\
\end{array}$ & $\begin{array}{c}123.340 \\
48.136 \\
\end{array}$ & 10,06 & 0,65 & 10.250 \\
\hline 316 & 476 & $\begin{array}{l}37,5 \times 400 \\
31,5 \times 325 \\
\end{array}$ & $\begin{array}{c}107.917 \\
40.085 \\
\end{array}$ & 9,99 & 0,65 & 8.819 \\
\hline 264 & 336 & $\begin{array}{c}31,5 \times 400 \\
25 \times 337 \\
\end{array}$ & $\begin{array}{r}93.730 \\
33.643 \\
\end{array}$ & 10,01 & 0,65 & 7.371 \\
\hline 248 & 316 & $\begin{array}{c}31,5 \times 400 \\
19 \times 337 \\
\end{array}$ & $\begin{array}{r}91.817 \\
33.520 \\
\end{array}$ & 10,30 & 0,65 & 6.932 \\
\hline 200 & 256 & $\begin{array}{l}25 \times 400 \\
16 \times 350 \\
\end{array}$ & $\begin{array}{r}76.133 \\
26.634 \\
\end{array}$ & 10,20 & 0,65 & 5.616 \\
\hline 155 & 197 & $\begin{array}{r}19 \times 400 \\
12,5 \times 362 \\
\end{array}$ & $\begin{array}{l}60.148 \\
20.216 \\
\end{array}$ & 10,13 & 0,65 & 4.321 \\
\hline 128 & 163 & $\begin{array}{r}16 \times 400 \\
9,5 \times 368 \\
\end{array}$ & $\begin{array}{l}51.171 \\
17.069 \\
\end{array}$ & 10.23 & 0,65 & 3.576 \\
\hline 107 & 136 & $\begin{array}{c}12,5 \times 400 \\
9,5 \times 375 \\
\end{array}$ & $\begin{array}{l}41.740 \\
13.336 \\
\end{array}$ & 9,9 & 0,65 & 2.984 \\
\hline
\end{tabular}


Perfis com altura de $700 \mathrm{~mm}$

\begin{tabular}{|c|c|c|c|c|c|c|c|}
\hline $\begin{array}{c}A \\
\left(\mathrm{~cm}^{2}\right) \\
\end{array}$ & $\begin{array}{c}p \\
(\mathrm{~kg} / \mathrm{m}) \\
\end{array}$ & $\begin{array}{c}\text { COMPOSI- } \\
\text { ÇÃO }\end{array}$ & $\begin{array}{c}\text { Ix/ly } \\
(\mathrm{cm} 4)\end{array}$ & $\begin{array}{c}\text { iy } \\
(\mathrm{cm})\end{array}$ & Ky & $\begin{array}{l}\phi c N n \\
(k N) \\
\end{array}$ & $\mathbf{G}_{\mathbf{A}}$ \\
\hline 708 & 556 & $\begin{array}{l}4=25 \times 400 \\
37,5 \times 310\end{array}$ & $\begin{array}{c}373.618 \\
48.136 \\
\end{array}$ & 22,97 & $\begin{array}{r}0,65 \\
2,9 \\
\end{array}$ & 15.930 & 9,2 \\
\hline 516 & 406 & $\begin{array}{l}4=19 \times 400 \\
2=16 \times 662\end{array}$ & 235.246 & 21,35 & $\begin{array}{r}0,65 \\
2,4 \\
\end{array}$ & 11.610 & 5,8 \\
\hline 424 & 332 & $\begin{array}{c}4=16 \times 400 \\
2=12,5 \times 668\end{array}$ & 197.869 & 21.60 & $\begin{array}{c}0,65 \\
2,2 \\
\end{array}$ & $\begin{array}{l}9.540 \\
8.590 \\
\end{array}$ & 4,9 \\
\hline 328 & 258 & $\begin{array}{l}4=12,5 \times 400 \\
2=9,5 \times 675\end{array}$ & 155.945 & 21,80 & $\begin{array}{c}0,65 \\
2,0 \\
\end{array}$ & $\begin{array}{l}7.380 \\
6.795 \\
\end{array}$ & 3,8 \\
\hline 354 & 278 & $\begin{array}{l}2=25 \times 400 \\
1=16 \times 650\end{array}$ & $\begin{array}{c}321.512 \\
52.106 \\
\end{array}$ & 12,13 & $\begin{array}{l}0,65 \\
1,95 \\
\end{array}$ & $\begin{array}{l}7.925 \\
6.085 \\
\end{array}$ & 3,6 \\
\hline 258 & 203 & $\begin{array}{l}2=19 \times 400 \\
1=16 \times 662\end{array}$ & $\begin{array}{c}214.957 \\
20.289 \\
\end{array}$ & 8,87 & $\begin{array}{l}0,65 \\
1,44 \\
\end{array}$ & $\begin{array}{r}5.555 \\
4.435 \\
\end{array}$ & 1,4 \\
\hline 212 & 166 & $\begin{array}{c}2=16 \times 400 \\
1=12,5 \times 668\end{array}$ & $\begin{array}{c}180.790 \\
17.078 \\
\end{array}$ & $\begin{array}{c}Q_{a}=0,9 \\
8,97 \\
\end{array}$ & $\begin{array}{r}0,65 \\
1,4 \\
\end{array}$ & $\begin{array}{l}4.188 \\
3.450 \\
\end{array}$ & 1,2 \\
\hline 164 & 129 & $\begin{array}{c}2=12,5 \times 400 \\
1=9,5 \times 675\end{array}$ & $\begin{array}{c}142.601 \\
13.344\end{array}$ & $\begin{array}{c}Q_{a}=0,85 \\
9,02\end{array}$ & $\begin{array}{c}0,65 \\
1,3\end{array}$ & $\begin{array}{l}3.042 \\
2.610 \\
\end{array}$ & 0,9 \\
\hline
\end{tabular}


Perfis com altura de $800 \mathrm{~mm}$

\begin{tabular}{|c|c|c|c|c|c|c|c|}
\hline $\begin{array}{c}\mathrm{P} \\
(\mathrm{kg} / \mathrm{m})\end{array}$ & $\begin{array}{c}A \\
\left(\mathrm{~cm}^{2}\right) \\
\end{array}$ & $\begin{array}{c}\text { COMPOSI- } \\
\text { ÇÃO }\end{array}$ & $\begin{array}{c}1 x / l y \\
(\mathrm{~cm} 4)\end{array}$ & $\begin{array}{c}\text { iy } \\
\text { (cm) }\end{array}$ & $K_{v}$ & $\begin{array}{l}\phi c N n \\
(k N)\end{array}$ & $G_{A}$ \\
\hline 867 & 1104 & $\begin{array}{r}64 \times 600 \\
50 \times 672 \\
\end{array}$ & $\begin{array}{c}1.169 .121 \\
231.100 \\
\end{array}$ & 14,47 & $\begin{array}{l}0,65 \\
2,8 \\
\end{array}$ & $\begin{array}{r}24.840 \\
14.930 \\
\end{array}$ & 8 \\
\hline 800 & 1020 & $\begin{array}{r}64 \times 600 \\
37,5 \times 672 \\
\end{array}$ & $\begin{array}{c}1.137 .510 \\
230.695 \\
\end{array}$ & 15,04 & $\begin{array}{c}0,65 \\
2,8 \\
\end{array}$ & $\begin{array}{l}22.950 \\
14.090 \\
\end{array}$ & 8 \\
\hline 718 & 915 & $\begin{array}{r}50 \times 600 \\
45 \times 700 \\
\end{array}$ & $\begin{array}{r}973.625 \\
180.532 \\
\end{array}$ & 14,05 & $\begin{array}{c}0,65 \\
2,4 \\
\end{array}$ & $\begin{array}{r}20.588 \\
13.423 \\
\end{array}$ & 6 \\
\hline 654 & 863 & $\begin{array}{r}50 \times 600 \\
37,5 \times 700 \\
\end{array}$ & $\begin{array}{r}952.188 \\
180.308 \\
\end{array}$ & 14,46 & $\begin{array}{c}0,65 \\
2,4 \\
\end{array}$ & $\begin{array}{r}19.418 \\
13.425 \\
\end{array}$ & 6 \\
\hline 599 & 764 & $\begin{array}{c}45 \times 600 \\
31,5 \times 710 \\
\end{array}$ & $\begin{array}{r}864.397 \\
162.185 \\
\end{array}$ & 14,57 & $\begin{array}{c}0,65 \\
2,3 \\
\end{array}$ & $\begin{array}{r}17.190 \\
12.915 \\
\end{array}$ & 5,6 \\
\hline 563 & 718 & $\begin{array}{r}45 \times 600 \\
25 \times 710 \\
\end{array}$ & $\begin{array}{r}845.810 \\
162.092 \\
\end{array}$ & 15,03 & $\begin{array}{c}0,65 \\
2,3 \\
\end{array}$ & $\begin{array}{r}16.155 \\
11.280 \\
\end{array}$ & 5,6 \\
\hline 495 & 631 & $\begin{array}{c}37,5 \times 600 \\
25 \times 725 \\
\end{array}$ & $\begin{array}{l}734.000 \\
135.041 \\
\end{array}$ & 14,63 & $\begin{array}{c}0,65 \\
2,2 \\
\end{array}$ & $\begin{array}{l}14.198 \\
11.200 \\
\end{array}$ & 4,7 \\
\hline 462 & 588 & $\begin{array}{c}37,5 \times 600 \\
19 \times 725 \\
\end{array}$ & $\begin{array}{l}714.947 \\
135.094 \\
\end{array}$ & 15,15 & $\begin{array}{c}0,65 \\
2,2 \\
\end{array}$ & $\begin{array}{r}13.230 \\
10.610 \\
\end{array}$ & 4,7 \\
\hline 406 & 518 & $\begin{array}{c}31,5 \times 600 \\
19 \times 737 \\
\end{array}$ & $\begin{array}{r}621.442 \\
113.442 \\
\end{array}$ & 14,80 & $\begin{array}{c}0,65 \\
2,0 \\
\end{array}$ & $\begin{array}{c}11.305 \\
9.630 \\
\end{array}$ & 4 \\
\hline 347 & 443 & $\begin{array}{l}25 \times 600 \\
19 \times 750 \\
\end{array}$ & $\begin{array}{c}517.420 \\
90.043 \\
\end{array}$ & 14,26 & $\begin{array}{l}0,65 \\
1,85 \\
\end{array}$ & $\begin{array}{l}9.968 \\
8.350 \\
\end{array}$ & 3 \\
\hline 330 & 420 & $\begin{array}{l}25 \times 600 \\
16 \times 750 \\
\end{array}$ & $\begin{array}{c}506.875 \\
90.025 \\
\end{array}$ & $\begin{array}{c}Q_{\lambda}=0,97 \\
14,64\end{array}$ & $\begin{array}{l}0,65 \\
1,85 \\
\end{array}$ & $\begin{array}{l}9.167 \\
7.790 \\
\end{array}$ & 3 \\
\hline 254 & 323 & $\begin{array}{r}19 \times 600 \\
12,5 \times 762 \\
\end{array}$ & $\begin{array}{c}393.835 \\
68.412 \\
\end{array}$ & $\begin{array}{c}Q_{\lambda}=0,91 \\
14,55\end{array}$ & $\begin{array}{c}0,65 \\
1,7 \\
\end{array}$ & $\begin{array}{l}6.613 \\
5.820 \\
\end{array}$ & 4 \\
\hline 228 & 265 & $\begin{array}{l}16 \times 600 \\
9,5 \times 768\end{array}$ & $\begin{array}{c}331.050 \\
57.606\end{array}$ & $\begin{array}{c}Q=0,81 \\
14,74\end{array}$ & $\begin{array}{c}0,65 \\
1,5\end{array}$ & $\begin{array}{l}4.830 \\
4.450\end{array}$ & 2 \\
\hline
\end{tabular}


Perfis com altura de $1140 \mathrm{~mm}$

\begin{tabular}{|c|c|c|c|c|c|c|c|}
\hline $\begin{array}{c}P \\
(\mathrm{~kg} / \mathrm{m})\end{array}$ & $\begin{array}{c}A \\
\left(\mathrm{~cm}^{2}\right)\end{array}$ & $\begin{array}{c}\text { COMPOSI- } \\
\text { ÇÃO }\end{array}$ & $\begin{array}{c}\mid x / l y \\
(\mathrm{~cm} 4)\end{array}$ & $\begin{array}{c}\text { iy } \\
\text { (cm) }\end{array}$ & Ky & $\begin{array}{l}\phi \mathrm{cNn} \\
(\mathrm{kN})\end{array}$ & $\mathbf{G}_{\mathbf{A}}$ \\
\hline 1000 & 1274 & $\begin{array}{r}64 \times 600 \\
50 \times 1012 \\
\end{array}$ & $\begin{array}{c}2.657 .400 \\
231.454 \\
\end{array}$ & 13,48 & $\begin{array}{l}0,65 \\
2,75 \\
\end{array}$ & $\begin{array}{r}28.665 \\
16.395 \\
\end{array}$ & 8 \\
\hline 838 & 1068 & $\begin{array}{r}50 \times 600 \\
45 \times 1040 \\
\end{array}$ & $\begin{array}{c}2.252 .093 \\
180.790 \\
\end{array}$ & 13,01 & $\begin{array}{c}0,65 \\
2,5 \\
\end{array}$ & $\begin{array}{r}24.030 \\
14.445 \\
\end{array}$ & 6,3 \\
\hline 733 & 934 & $\begin{array}{r}45 \times 600 \\
37,5 \times 1050 \\
\end{array}$ & $\begin{array}{c}1.981 .353 \\
162.461 \\
\end{array}$ & 13,19 & $\begin{array}{c}0,65 \\
2,4 \\
\end{array}$ & $\begin{array}{l}21.015 \\
13.155 \\
\end{array}$ & 5,7 \\
\hline 630 & 803 & $\begin{array}{r}45 \times 600 \\
25 \times 1050 \\
\end{array}$ & $\begin{array}{c}1.860 .763 \\
162.137 \\
\end{array}$ & 14,21 & $\begin{array}{l}0,65 \\
2,4 \\
\end{array}$ & $\begin{array}{r}18.068 \\
11.890 \\
\end{array}$ & 5,7 \\
\hline 562 & 716 & $\begin{array}{l}37,5 \times 600 \\
25 \times 1065 \\
\end{array}$ & $\begin{array}{c}1.619 .628 \\
135.139 \\
\end{array}$ & 13,74 & $\begin{array}{c}0,65 \\
2,2 \\
\end{array}$ & $\begin{array}{r}16.110 \\
12.310 \\
\end{array}$ & 4,7 \\
\hline 457 & 583 & $\begin{array}{l}31,5 \times 600 \\
19 \times 1077 \\
\end{array}$ & $\begin{array}{c}1.359 .299 \\
113.462 \\
\end{array}$ & $\begin{array}{c}Q_{A}=0,91 \\
13,95 \\
\end{array}$ & $\begin{array}{c}0,65 \\
2,5 \\
\end{array}$ & $\begin{array}{l}11.937 \\
9.716 \\
\end{array}$ & 4 \\
\hline 398 & 507 & $\begin{array}{r}25 \times 600 \\
19 \times 1090 \\
\end{array}$ & $\begin{array}{c}1.139 .621 \\
90.062 \\
\end{array}$ & $\begin{array}{c}Q_{a}=0,89 \\
13,33\end{array}$ & $\begin{array}{l}0,65 \\
1,85 \\
\end{array}$ & $\begin{array}{l}10.150 \\
8.510 \\
\end{array}$ & 3 \\
\hline 372 & 474 & $\begin{array}{r}25 \times 600 \\
16 \times 1090 \\
\end{array}$ & $\begin{array}{c}1.105 .245 \\
90.037 \\
\end{array}$ & $\begin{array}{c}Q_{\lambda}=0,86 \\
13,78\end{array}$ & $\begin{array}{l}0,65 \\
1,85 \\
\end{array}$ & $\begin{array}{l}9.171 \\
8.630 \\
\end{array}$ & 3 \\
\hline 287 & 366 & $\begin{array}{r}19 \times 600 \\
12.5 \times 1102 \\
\end{array}$ & $\begin{array}{c}855.757 \\
68.418 \\
\end{array}$ & 13,67 & $\begin{array}{c}0,65 \\
1,7 \\
\end{array}$ & $\begin{array}{r}6.670 \\
5.860 \\
\end{array}$ & 2,4 \\
\hline 259 & 330 & $\begin{array}{c}16 \times 600 \\
12,5 \times 1108\end{array}$ & $\begin{array}{c}748.154 \\
57.618\end{array}$ & 13,21 & $\begin{array}{c}0,65 \\
1,6\end{array}$ & $\begin{array}{l}5.866 \\
5.220 \\
\end{array}$ & 2 \\
\hline
\end{tabular}


Para o cálculo do grau de rigidez que cada nó $\left(G_{A} ; G_{B}\right)$ foi uitlizado nas vigas o momento de inércia da seção mista homogeneizada, considerando-se como largura colaborante da laje a distancia entre os eixos de duas vigas adjascentes, e não mais a obtida no cálculo da seção mista, embora na determinação das solicitações e dos deslocamentos tenha sido esta a utilizada.

Finalmente, uma vez que as estruturas atendem as condições de segurança impostas pela norma brasileira, é possivel reunir, em um único quadro, os valores obtidos para o peso total e o consumo de aço, para cada uma delas.

\begin{tabular}{|c|c|c|c|c|c|}
\hline SISTEMA & $\begin{array}{c}\text { Peso } \\
\text { Total } \\
\text { em Aço } \\
\text { (t) } \\
\end{array}$ & $\begin{array}{c}\text { Consumo } \\
\qquad \mathrm{p} / \mathrm{m}^{2} \\
\left(\mathrm{k}_{\mathrm{a}} / \mathrm{m}^{2}\right)\end{array}$ & $\begin{array}{c}\text { Volume } \\
\text { de } \\
\text { concreto } \\
\left(\mathrm{m}^{3}\right) \\
\end{array}$ & $\begin{array}{c}\text { Diferença } \\
\text { em peso } \\
\text { (t) }\end{array}$ & Variação \\
\hline Aporticado & 1320 & 73,3 & - & - & 1,0 \\
\hline Núcleo concreto & 569 & 32 & 1126 & .751 & 0,431 \\
\hline Núcleo misto & 850 & 47 & 180 & -470 & 0,644 \\
\hline $\begin{array}{c}\text { Núcleo } \\
\text { aço/aporticado }\end{array}$ & 1272 & 70,7 & - & -48 & 0,964 \\
\hline Núcleo aço/trel. & 1183 & 65,7 & - & -137 & 0,896 \\
\hline Trel. vert. & 1135 & 63,0 & - & -185 & 0,860 \\
\hline $\begin{array}{c}\text { Tubular } \\
\text { aporticado } \\
\text { (núcleo metálico) }\end{array}$ & 1378 & 76,6 & - & +58 & 1,044 \\
\hline $\begin{array}{c}\text { Tubular } \\
\text { aporticado } \\
\text { (núcleo conc.) }\end{array}$ & 1074 & 59,7 & 1126 & -246 & 0,814 \\
\hline $\begin{array}{l}\text { Tubular treliçado } \\
\text { (núcleo metálico) }\end{array}$ & 1147 & 63,7 & - & -173 & 0,869 \\
\hline $\begin{array}{l}\text { Tubular treliçado } \\
\text { (núcleo conc.) }\end{array}$ & 845 & 46,9 & 1126 & -475 & 0,640 \\
\hline
\end{tabular}




\section{6 - RECOMENDAÇÕES E CONCLUSÕES}

\section{1 - SOBRE O EMPREGO DE ESTRUTURAS DE AÇO}

Nos capitulos iniciais deste trabalho, procurou-se enfatizar dois aspectos que sāo fundamentais para promover o emprego de estruturas de aço em edifícios de andares múltiplos

O primeiro aspecto é o do projeto de arquitetura, que quase sempre privilegia outros materiais estruturais. Neste caso especifico, a causa, ou falha, está nos cursos de formação que, a exemplo dos cursos de engenharia, näo costumam reservar uma carga horária satisfatória para este assunto.

Portanto, a solução deste problema não está restrito a este trabalho, que serve no máximo, como mais um alerta para o problema.

O segundo aspecto está ligado aos fatores construtivos, como os sistemas estruturais envolvidos, a racionalização da construçăo, o acabamento, a proteção e, como não podia deixar de ser, o custo relativo destas estruturas.

Foram também destacadas as múltiplas aplicações que são possiveis entre $o$ aço e os demais materiais estruturais e construtivos.

Evidentemente, a leitura destes capítulos não fornece um conhecimento profundo destes aspectos porém, e com esta finalidade os mesmos foram escritos, acredita-se que permitam uma primeira reflexão, que deve se estender também ao paralelo estabelecido entre os históricos internacional e o nacional, e as razões apresentadas para explicar a defasagem observada, que mais uma vez remetem para o ensino e a aplicação da arquitetura com aço.

Os dados fornecidos no item dedicado à racionalização são básicos, e assim devem ser entendidos, entretanto, devem estar presentes ao se iniciar um projeto de estruturas de aço. 
Resumidamente, devem ser memorizados os seguintes parâmetros que indicam a adoção do aço como elemento estrutural:

\author{
a-Grandes vãos a vencer \\ b-Solo com baixa capacidade suporte \\ c-Prazo exíguo para a construção \\ d-Construção sob condições meteorológicas adversas.
}

Uma vez decidido o uso do aço, os seguintes itens, também resumidos, auxiliam na otimização tanto do volume de aço a empregar como o custo final da construção.

a - Escolha do sistema estrutural, de modo a mobilizar pilares paredes e núcleos de serviços para formar a rigidez global.

b - Disposição das vigas dos pisos.

c - Possível integração da estrutura de aço com outros materiais quer estruturais, quer de fechamento.

d - Padronização dos perfis das vigas, pilares, diagonais e das ligaçōes.

e - Especificação para acabamento, pintura e proteção contra fogo.

Por ocasião do desenvolvimento do projeto, nem sempre se possui as informações que permitam a tomada de decisão mais acertada, mas não se deve deixar de tentar obtê-las.

\title{
6.2- SOBRE OS ASPECTOS ESTRUTURAIS
}

$\mathrm{Na}$ parte do trabalho reservado aos aspectos estruturais, diversas observações são pośsíveis.

A primeira delas é quanto à análise dinâmica da estrutura, quando excitada pela ação do vento. Os resultados obtidos indicam que as solicitações despertadas nas barras, assim como os deslocamentos no topo, são menores que os obtidos na análise estática. 
Este resultado não surpreende, uma vez que os períodos de recorrência adotados para as duas análsies são diferentes. Entretanto, a determinação da aceleração não pode deixar de ser feita, uma vez que é este o melhor parâmetro dinâmico para ànalisar o conforto humano.

A análise dinâmica não costuma ser abordada nos cursos de graduação, embora não seja difícil a sua assimilação. Também não costuma ser disciplina obrigatória nos cursos de pós-graduação. Entretanto, para as grandes estruturas sua aplicação é fundamental, mesmo que só para verificar o conforto humano, como já citado.

Por este motivo, foi feito o resumo da teoria da vibração, apresentada no item 3.3, que não tem a pretensão de ser conclusivo, abrangente ou completo, mas sim apenas uma pequena introdução ao assunto. Porém, esta introdução permite explicar os efeitos dinâmicos do vento e do choque dos calcanhares das pessoas nos pisos, que tendem a ser cada vez mais leves e portanto mais susceptiveis a este fenômeno.

Espera-se que o resumo teórico e os exemplos apresentados sejam suficientes para despertar o interesse e mostrar a necessidade da aplicação desta teoria.

Ainda na análise do vento vale salientar o acréscimo nas solicitações que ocorre ao ser considerado o momento de torção, despertado pelos efeitos de vizinhança. Entretanto, este aumento é mais significativo nos deslocamentos laterais e nas solicitações de flexão, pouco alterando os esforços de compressão.

Para a análise em segunda ordem, é mais uma vez o vento quem provoca os deslocamentos laterais de primeira ordem, mas os incrementos a estes deslocamentos são funçōes das ações verticais.

Existe neste campo uma idéia errônea de que é o vento quem provoca o efeito de segunda ordem, quando na verdade este é provocado pelo peso próprio da construção, somado à ação de sobrecarga.

Esclarecendo um pouco mais. Como pode ser observado no exemplo que foi desenvolvido, a ação lateral do vento provoca deslocamentos laterais que, caso não exista força lateral aplicada, não sofrerão majoração.

Entretanto, cáso a força vertical aplicada, na presença destes deslocamentos seja significativa, o acréscimo a estes deslocamentos será grande, sendo portanto significativo o efeito da segunda ordem. Portanto, o efeito de segunda ordem depende da ordem de grandeza dos deslocamentos iniciais e da intensidade das forças verticais. 
A discussão desenvolvida no item 3.5 corrobora as afirmaçōes anteriores e compara os diversos procedimentos adotados para quantificar este efeito, conduzindo à conclusão de que todos partem da mesma hipótese inicial, portanto chegam a um mesmo resultado final, a menos das aproximações observadas.

Quanto à rigidez teórica das ligaçōes, que não coincide com a observada no comportamento real, foi necessário estudar melhor este desempenho. Embora já existam diversos trabalhos, que representam avanços significativos, possuem estes uma formulaçāo extremamente trabalhosa e de difícil implementação em programas computacionais destinados à análise de grandes estruturas.

Sobre os programas existentes cabe também observar que a sua utilização, não exime o projetista de desenvolver uma visão crítica do desempenho e do comportamento da estrutura, até pelo contrário, exigem que o mesmo tenha uma idéia muito clara do resultado esperado.

O estudo puro e simples de um elemento isolado, ou de uma ligação em particular, não costuma. fornecer informações suficientes para delinear a resposta da estrutura.

No item 3.6 procurou-se mostrar que as ligaçōes consideradas em principio como rótulas, sāo na verdade engastes, com pequena rigidez é verdade, mas ainda assim são engastes, e como tal deveriam ser tratadas, para verificar a sua influencia no comportamento global da estrutura.

As ligações entre vigas ou entre pilar e viga, quando consideradas como rotuladas, após a execução da laje de piso recebem um aumento na sua rigidez, que não mais permite considerá-las como rótulas, a menos que sejam toleradas grandes desvios dos resultados esperados. Também para este caso foi desenvolvido um modêlo matemático que permite avaliar, de modo fácil e direto, o grau de rigidez desta nova ligação.

Para o edifício modelo, visando diminuir os custos de montagem e de fabricaçāo, pode ser empregada a ligação proposta na figura 6.1 , onde a ligação da alma possui rigidez suficiente para assegurar a estabilidade da construção durante a fase de montagem e a soldas das mesas, somadas à contribuição da laje de piso, garantem a estabilidade e a rigidez necessárias para a vida útil esperada.

Deste modo, a montagem é parafusada para permitir o rápido erguimento do "esqueleto" e as fases posteriores, podem ser executadas junto com a cura do concreto. 
Ao desenvolver o edifício exemplo procurou-se adotar uma sequência mais voltada para a prática da engenharia, visando fornecer um primeiro roteiro para os profissionais que se iniciam em cálculo e dimensionamento.
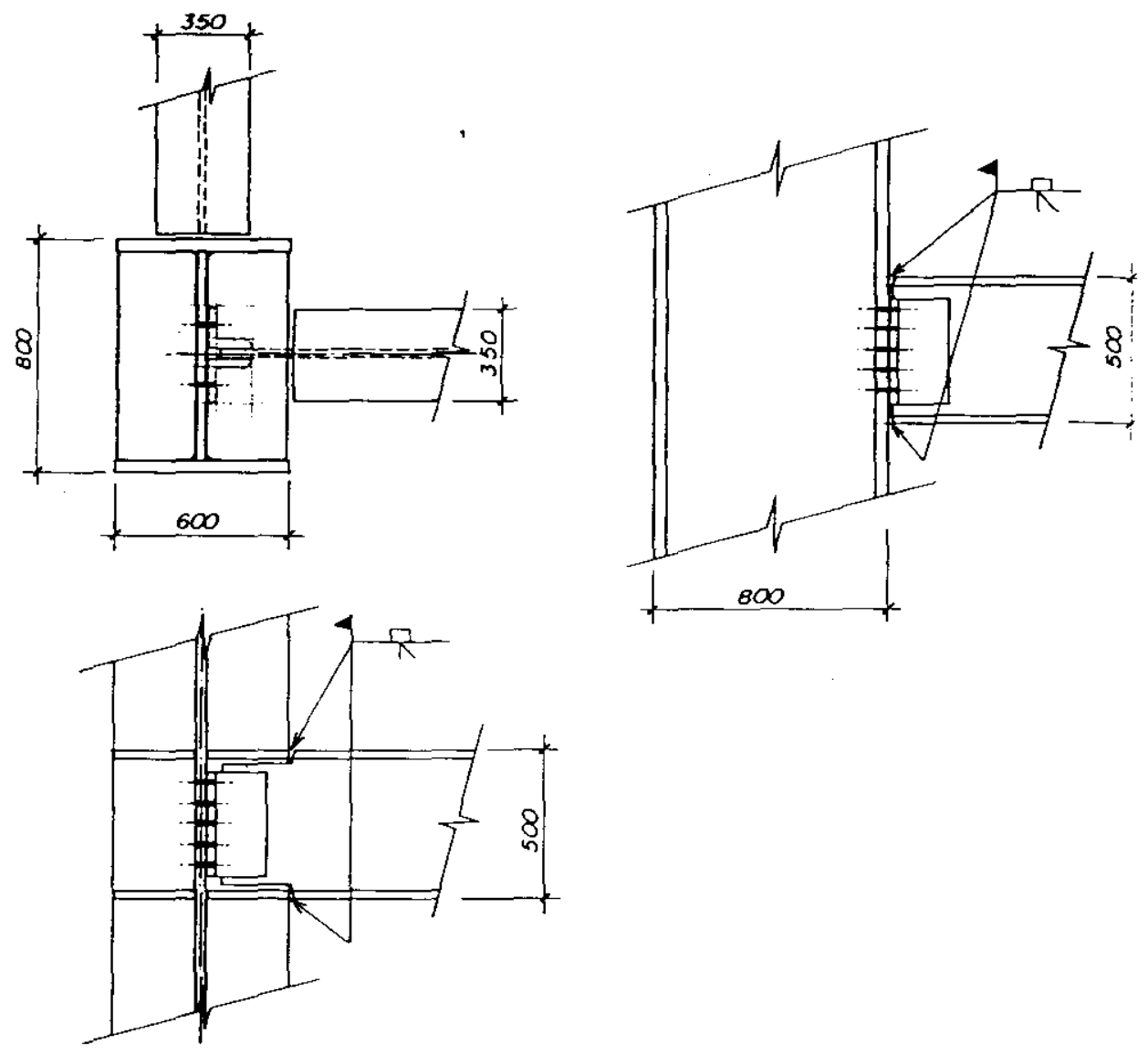

Figura 6.1 - Ligação Típica para Viga/Coluna

Neste exemplo foi enfatizada a necessidade de levar em conta o comportamento espacial da estrutura, verificando como as solicitaçōes se distribuem entre os diversos elementos, mas e principalmente, como se determina com mais precisão a parte da ação global do vento que corresponde a cada pórtico. Em estruturas de grande porte, como a analisada, não se justifica a adoção do critério da área de influência, pois a mesm pode conduzir a desvios muito grandes do valor "exato".

Outra observação pertinente é quanto ao momento de torção, cuja absorção é necessariamente distribuída proporcionalmente à rigidez dos pórticos. Mais uma vez ocorre uma distribuição espacial dos esforços despertados na estrutura. 
Para analisar o comportamento espacial de uma estrutura, como a do exemplo, o caminho mais fácil é através de um programa computacional, tridimensional. Entretanto, no caso de profissonais com pouca ou nenhuma experiência, ou então quando precisa-se ter uma idéia do resultado esperado, foi apresentado no item em questão, um procedimento clássico, que foi muito utilizado antes do advento dos computadores, para simular manualmente o comportamento espacial de estruturas.

Este processo clássico, que possui seus fundamentos encravados nos primórdios da mecânica das estruturas, forneceu resultados quase tão precisos quanto os obtidos pela análise computacional, como pode ser observado nas planilhas correspondentes.

O comportamento espacial também está presente na análise dinâmica e na não linear ou de segunda ordem. Nestas duas situações não é possivel conceber que um pórtico, ou pior ainda um pilar, possa comportar-se independente do restante da estrutura. Vale alertar mais uma vez, que qualquer ação aplicada em qualquer ponto da estrutura, será absorvida mobilizando todos os elementos estruturais.

No caso da ação do vento parece ser facilmente percebida esta iteração espacial e também parece ser facilmente compreesivel a decomposição da ação global entre todos os elementos resistentes. Entretanto, no caso da análise não linear, até pela forma como o assunto costuma ser apresentado, esta iteração não costuma ser muito evidenciada, chamando-se a atenção portanto, que não possui sentido prático ou físico a análise em segunda ordem de um elelmento isolado..

As açōes do vento, tanto estática como dinâmica, incluindo-se o momento de torção, podem ser representadas por forças cujas intensidades são determinadas considerando a presença das lajes, que por possuírem grande rigidez no seu plano, podem ser consideradas como indeformáveis, apresentando deslocamentos de corpo rígido, que garantem o alinhamento dos deslocamentos em cada andar.

Para a análise de segunda ordem, os desiocamentos de cada pórtico, quando calculados separadamente, podem não manter este alinhamento, que na verdade "existe, exigindo assim uma redistribuição destes deslocamentos, mantendo as condições de equilibrio entre as ações e reações. Baseando-se nas observaçōes anteriores foi desenvolvido 0 procedimento alternativo, que permitiu determinar os deslocamentos finais, alinhados e em equilibrio com as ações externas. 
Com este procedimento foi possivel obter, manualmente, as ações e os deslocamentos de todos os pórticos na laje de cobertura, que não apresentam diferenças significativas em relação aos obtidos por procedimento computacional. Entretanto, o fato que mais chama a atenção nesta análise é a diferença encontrada entre os resultados obtidos pelos procedimentos recomendados nas normas utilizadas.

Segundo a NBR-8800, ao ser utilizada a análise de primeira ordem, os efeitos de excentricidade e de deslocabilidades, são levados em conta nos fatores $C_{m}$ e $\mu$, como mostrado no capitulo correspondente. Por este procedimento, que é o mais utilizado na prática, foi dimensionado o edifício exemplo.

Tomando, de maneira aleatória, um determinado pilar como exempio, no caso foi escolhido o do quinto andar, na fila B, eixo 2, observou-se que o mesmo, por este procedimento, ficou com um índice de aproveitamento de 1,02 ou seja, praticamente $100 \%$. Aplicando-se o procedimento do LRFD, ainda em teoria de primeira ordem, encontrou-se para o mesmo pilar um indice de aproveitamento de $72 \%$.

Esta diferença é facilmente justificada, uma vez que as duas normas utilizam coeficientes de ponderação das ações muito diferentes e também são diferentes as equaçōes de iteração. Recuperando estas informações só para facilitar esta análise, têm-se:

a - Formulações das combinações

a - 1) Pela NBR-8800

$$
C=1,4 P_{p}+1,5 S_{c} \text { e } 1,4 W
$$

a - 2) Pelo LRFD

$$
\mathrm{C}=1,2 \mathrm{P}_{\mathrm{p}}+0,5 \mathrm{~S}_{\mathrm{c}}+1,3 \mathrm{w}
$$

b - Equações de iteração

b - 1) Da NBR-8800

$$
\frac{N_{d}}{\phi_{n} N_{n}}+\frac{C_{m} M_{d}}{\left(1-\frac{N_{d}}{0,73 N_{e}}\right) \phi_{b} M_{n}} \leq 1,0
$$




\section{b - 2 ) Do LRFD}

$$
\frac{P_{u}}{\phi P_{n}}+\frac{8}{9} \frac{M_{u}}{\phi_{b} M_{n}} \leq 1,0
$$

Também deve ser lembrado que são diferentes as formas de obtenção dos valores de $\phi_{c} N_{n}$ e $\phi P_{n}$, bem como de $M_{d} C_{m} /\left(1-N_{d} / N_{e}\right)$ e de $8 M_{u} / 9 \phi_{b} M_{n}$.

Realmente, nāo tem muito sentido comparar estes dois resultados, uma vez que cada um expressa procedimentos muito diferentes entre sí. Porém, ao aplicar à estrutura uma análise de segunda ordem e verificar o mesmo pilar pelas duas normas, encontra-se como índice de aproveitamento, $71 \%$ pela NBR- 8800 e $63 \%$ pelo LRFD, sendo que em teoria de primeira ordem, estas índices ficaram em torno de $100 \%$ para a NBR 8800 e de $72 \%$ pelo LRFD.

Agora as diferenças entre os índices obtidos em teoria de primeira ordem e 0 de segunda preocupam. No caso específico da NBR-8800 esta diferença pode levar à conclusōes falsas como a de que uma estrutura que não atende as condições de segurança quando analisada em primeira ordem, pode passar a atender quando analisada em segunda ordem, ou seja, a verificação em segunda ordem parece ser mais branda que a de primeira. Evidentemente esta é uma conclusão falsa e até mesmo pueril.

No caso do LRFD, a diferença encontrada é menor, podendo ser entendida como reflexo das aproximações introduzidas no procedimento aproximado, que está embutido na verificação em primeira ordem.

Comparando-se as solicitações de cálculo encontradas nas duas análises e segundo as duas normas, verifica-se que as obtidas em segunda ordem são maiores, em torno de $5 \%$, das obtidas em primeira ordem. Este é um resultado esperado, sendo coerente com os encontrados em outras estruturas já analisadas.

Entretanto, as resistências de cálculo à compressão para a análise em segunda ordem, são maiores que as determinadas para a análise em primeira ordem. No caso da NBR-8800 o aumento é de quase $45 \%$ e para 0 LRFD é de $22 \%$.

Estas diferenças entre os índices de aproveitamento preocupam bastante, pois mais uma vez os resultados encontrados são muito diferentes dos esperados e ocorreram devido à variação do comprimento de flambagem do pilar, utilizado para cada análise. 
$\mathrm{Na}$ análise em primeira ordem o comprimento foi da ordem de três vezes o comprimento real, enquanto que na análise em segunda ordem este comprimento tem de ser menor ou no máximo igual, ao comprimento real. Estes comprimentos expressam as condições deslocável e indeslocável respectivamente, impostas à estrutura pelas duas normas.

Como os comprimentos de flambagem influenciam a resistência à flambagem, então comprimentos menores conduzem a resistências maiores, que por sua vez levam a valores maiores nos momentos resistentes de cálculo. Deste modo, a redução do comprimento de flambagem aumenta a resistencia global da coluna, tanto à compressão como à flexão.

$E$, este aumento é muito maior que $o$ aumento que as solicitações em segunda ordem apresentam, em relação às solicitações de primeira ordem. Até aqui consegue-se explicar as diferenças encontradas, mas não justificálas. Em uma estrutura indeslocável, por exemplo um pórtico treliçado, ocorre aumento nas solicitações, mas não nos comprimentos de flambagem para as duas análises em discussão. Portanto, neste pórtico a análise em segunda ordem conduz a um índice de aproveitamento maior que o obtido em primeira ordem, ou seja, o contrário do obtido no pórtico deslocável.

A conclusão óbvia é que o comprimento de flambagem das colunas em estruturas deslocáveis deve ser diminuido, quando só se aplica a teoria de primeira ordem. Portanto, ou reestuda-se o ábaco para os valores de $\mathrm{K}$ ou adota-se um outro procedimento para determiná-lo.

Também pode ser concluido, que passou da hora de estudar, ou no mínimo de igualar, os coeficientes de majoração das ações das diversas normas brasileiras, pois como pode ser observado, os valores indicados na NBR-8800 diferem das demais normas, sendo inclusive maiores que os indicados em outras normas estrangeiras, como o LRFD, ou a BS 5950.

\section{3- SOBRE A ANÁLISE COMPARATIVA}

Finalmente, sobre os sistemas estruturais passiveis de serem utilizados e os que foram usados como exemplo e discutidos ao longo deste trabalho, devem ser observados e mesmo enfatizados, alguns aspectos construtivos bastante peculiares, que dizem respeito a todas as construçōes em geral e a estes sistemas em particular. 
A primeira observação é quanto às açōes verticais que tendem a se concentrar nas colunas centrais, causando assim uma natural concentração de massa e de rigidez do sistema portante junto a estes pontos. Nas construções com núcleos de serviços situados no perímetro externo, esta concentração não será tão evidente, mas assim mesmo ocorrerá.

$O$ fato de acontecer esta concentração não deve ser ignorado pelos projetistas, que devem inclusive tirar partido desta situação na definição do sistema estrutural e do sistema de enrijecimento, também chamado por alguns autores como sistema de contraventamento.

As formas de enrijecer a estrutura em geral, e em particular nestes pontos centrais, foram discutidas no texto, mas nāo custa repetir que estas formas de enrijecimento acabam dando origem aos diversos sistemas estruturais, que foram apresentados em sua essência ao longo do trabalho.

A presença dos núcleos de serviço e o aproveitamento destes como parte do sistema estrutural, produz vantagens evidentes, como a redução no consumo de aço e nos deslocamentos dos andares intermediários, como pode ser visto no quadro seguinte onde foram representados os deslocamentos dos diversos sistemas.

Os diversos sistemas analisados, contemplam um edifício com 20 andares que, como já definido na introdução, pode ser considerado baixo se construído em uma capital, mas que cobre a grande maioria das construçōes existentes fora destas cidades principais.

No entanto, tanto na bibliografia como na introdução deste trabalho, foram apresentados diversos edifícios com mais de 100 andares e o exemplo desenvolvido limitou-se a tímidos 20 pavimentos. A explicação para esta aparente contradição reside na inata qualidade do homem de superar recordes e marcas, de imortalizar-se através de construções gigantescas e megalomaníacas, sem nunca atentar para o lado social que toda construção deve ter.

Para as condiçōes de desenvolvimento sócio-econômico que nosso pais apresenta, julgou-se que 20 andares representam a altura ideal para edifícios a serem construídos na quase totalidade das nossas cidades, de modo a não inviabilizar os serviços urbanos existentes, tendo assim uma maior importancia social.

E, para construções com esta altura, as informações e os procedimentos contidos neste trabalho, conduzem a uma quase igualdade de desempenho entre os diversos sistemas. 
Na parte específica de consumo de aço, os sistemas formados por treliças, em qualquer posição, levam nítida vantagem em relação aos não treliçados correspondentes.

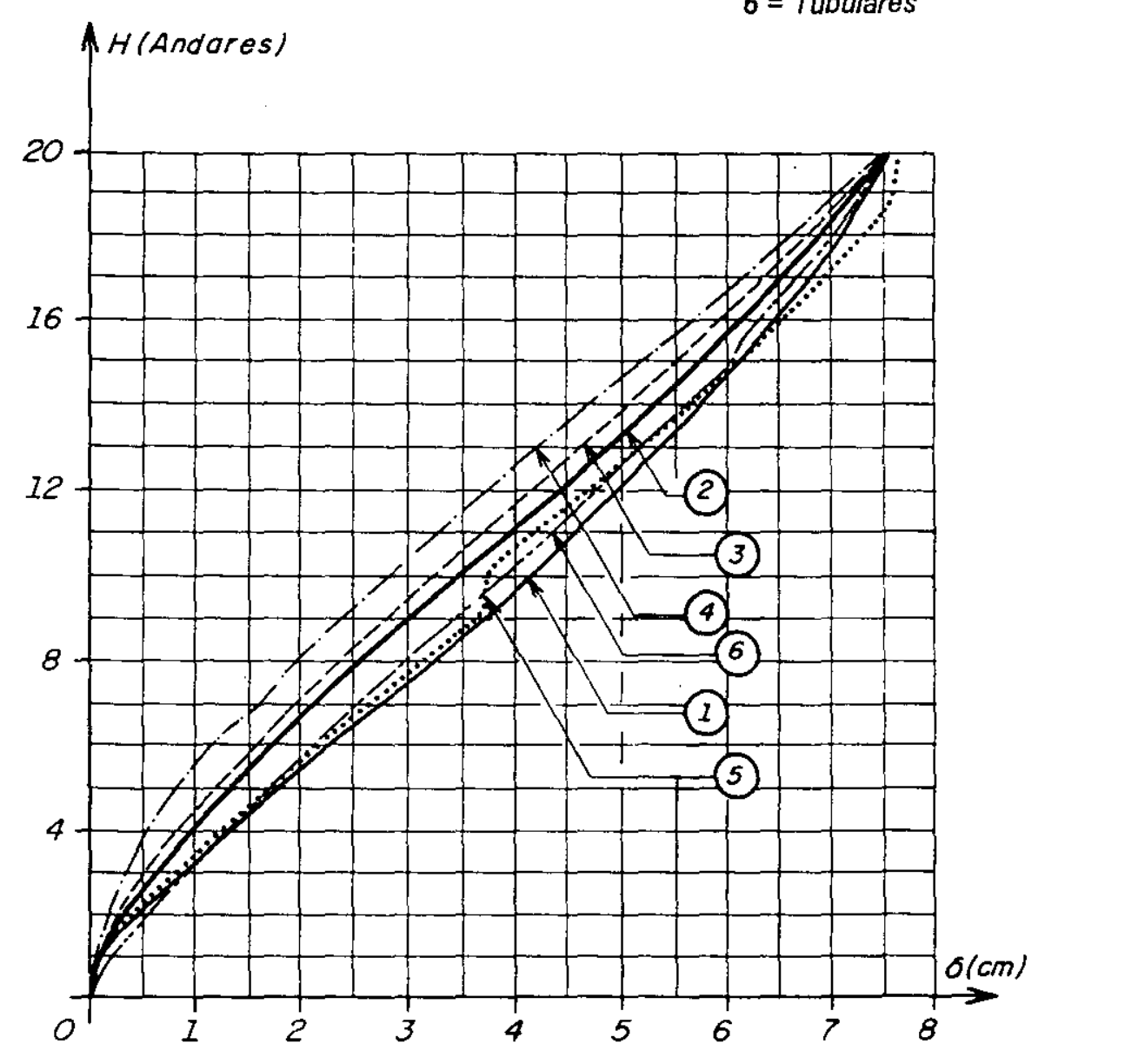

$$
\begin{aligned}
& 1=\text { Aporticado } \\
& 2=\text { Núcleo Aço/Concreto } \\
& 3=\text { Núcleo de Aço Aporticado } \\
& 4=\text { Núcleos de Concreto } \\
& 5=\text { "Outrigger" } \\
& 6=\text { Tubulares }
\end{aligned}
$$

Figura 6.2 - Deslocamentos Horizontais dos Diversos Sistemas

Esta vantagem aparente é explicada pela consideração deslocável das treliçadas, comó já comentado. E, esta vantagem também ocorre com a aplicação de concreto nos núcleos, porém neste caso deve ser levado em conta o custo do concreto utilizado e o tempo de execução; enquanto no caso anterior não pode ser esquecido o maior número de barras $e$, consequentemente de ligações, que os sistemas treliçados apresentam.. 
Resumindo, em termos dos custos globais da estrutura, qualquer um dos sistemas pode ser aplicado ao edifício em questão.

Quanto aos consumos obtidos, que podem ser considerados altos para um edifício de 20 andares, cabe alertar que a otimização realizada não teve como meta reduzir estes consumos, mas apenas uniformizar 0 comportamento estrutural, tanto nos deslocamentos como nos índices de aproveitamento das barras, para permitir comparar os sistemas estruturais analisados.

\section{4- TEMAS PARA CONTINUAÇÃO DA PESQUISA}

Como tema para pesquisas que deem continuidade a este trabalho, recomenda-se:

a - Estudo teórico-experimental do comportamento à flambagem de colunas em pórticos deslocáveis e indeslocáveis, visando aperfeiçoar a aplicação da análise não linear.

b - Análise experimental para aferição do modelo teórico, apresentado neste trabalho, para a determinação da rigidez das ligações viga- coluna e sua implicação na rigidez global do pórtico formado com elas.

C - Estudo dos coeficientes de ponderação das ações, apresentados pela NBR-8800, visando sua uniformização com os apresentados nas demais normas.

d - Estudo da resistência das estruturas de aço ao fogo.

e - Desenvolver estudos sobre o comportamento ao fogo, para vigas e pilares. 


\section{BIBLIOGRAFIA}

1- AL-MASHARY, F.; CHEN, W.F. (1991). Simplified second-order inelastic analysis for steel-frames. The Structural Engineer, v.69, n. 3, p.395-399, Dec.

2- AMERICAN INSTITUTE OF STEEL CONSTRUCTION (1986). Load and resistance factor design: specifications for structural steel buildings. Chicago, AlSC.

3- AMERICAN INSTITUTE OF STEEL CONSTRUCTION (1989). Allowable stress design: specifications for structural steel buildings. Chicago, AISC.

4- ASSOCIAÇÃO BRASILEIRA DE NORMAS TÉCNICAS (1988). NBR 5628 Componentes construtivos estruturais: determinação da resistência ao fogo. Rio de Janeiro, ABNT.

5- ASSOCIAÇÃO BRASILEIRA DE NORMAS TÉCNICAS (1980). NBR 6120 Cargas para cálculo de estruturas de edificações. Rio de Janeiro, ABNT.

6- ASSOCIAÇÃO BRASILEIRA DE NORMAS TÉCNICAS (1988). NBR 6123 Forças devidas ao vento em edificações. Rio de Janeiro, ABNT.

7- ASSOCIAÇÃO BRASILEIRA DE NORMAS TÉCNICAS (1984). NBR 8681 Ações e segurança nas estruturas. Rio de Janeiro, ABNT.

8- ASSOCIAÇÃO BRASILEIRA DE NORMAS TÉCNICAS (1986). NBR 8800 Projeto e execução de estruturas de aço de edifícios. Rio de Janeiro, ABNT.

9- BALLIO, G.; MAZZOLANI, F.M. (1988). Structure in acciaio. Milano, Ulico Hoelpi. 
10- BARAKAT, M.; CHEN, W. (1991). Design analysis of semi-rigid frames: evaluation and implementation. Engineering Journal, AISC, p.55-64, second quarter.

11- BELLEl, I.H. (1994). Edifícios industriais em aço: projeto e cálculo. São Paulo, PINI.

12- BLESSMAN, J. (1983). Aerodinâmica das construções. Porto Alegre, UFRGS.

13- BRITISH STANDARS INSTITUTION (1990). BS 5950 - Part 1: Structural use of steelwork in building. London.

14- CHEN, W.F.; LUI, E.M. (1991). Stability of steel frames. Florida, CRC Press.

15- CONNOR, J.J.; POUANGARE, C.C. (1991). Simple model for design of framed-tube structures. Journal of Structural Engineering, ASCE, v.117, n.12, p.3623-3644, December.

16- DIAS, L.A.M. (1993). Edificações de aço no Brasil. São Paulo, Zigurate.

17- FIELDING, D.J. (1994). Frame response considering plastic panel hinges. Engineering Journal, AISC, first quarter.

18- FURLONG, R.W. (1993). Slenderness of columns in braced frames. Journal of Structural Engineering, ASCE, v.119, n.11, p.3405-3415, November.

19- GALAMBOS, T.V. (1988). Guide to stability design criteria for metal structures. 4.ed. New York, John Wiley \& Sons.

20- GUIDE for the design and construction of mill buildings (1983). Pittsburgh, Pa., AISE. Technical Report n.13

21- HAJJAR, J.F.; WHITE, D.W. (1994). The accurancy of column stability calculations in unbraced frames and the influence of columns with effective length factor less than one. Engineering Journal, AISC, p.81-97, third quarter.

22- HART, F.; HENN, W.; SONTAG, H. (1985). Multi-storey buildings in steel. 2.ed. New York, Nichols Publishing. 
23- IWANKIW, N.R. (1984). Note on beam-column moment amplification factor. Engineering Journal, AISC, p.21-33, first quarter.

24- KISHI, $\mathbf{N}$ et al. (1993). Design and of semi-rigid connections for frame analysis. Engineering Journal, ArSC, p.90-107, third quarter.

25- LAWSON, T.V. (1980). Wind effects on buildings. London, Applied Science Publishers.

26- LEON, R.T. (1984). Composite semi-rigid construction. Engineering Journal, AISC, v.21, p.57-67, second quarter.

27- LIEW, J.Y.R.; WHITE, D.W. (1993). Second-order refined plastic-hinge analysis for framed design. Journal of Structural Engineering, ASCE, v.119, n.11, p.3196-3237, November.

28- MALITE, M. (1993). Análise do comportamento estrutural de vigas mistas aço-concreto constituídas por perfis de chapa dobrada. São Carlos. $2 \mathrm{v}$. Tese (doutorado) - Universidade de São Paulo, Escola de Engenharia de São Carlos.

29- MANUAL brasileiro para cálculo de estruturas metálicas (1986). Brasilia, Ministério da Indústria e Comércio, Secretaria de Tecnologia Industrial. v.1

30- MOORE, D.B.; NETHECORT, D.A.; KIREY, P.A. (1993). Testing steel frames at full scale. The Structural Engineer, v.71, n.23-24, p.418-435, December.

31- PAZ, M. Structural dynamics. New York, Van Nostrand Reinhold, 1975.

32- PRELORENTZOU, P.A. (1991). Um estudo sobre ligações viga-coluna em estruturas de aço. São Carlos. 221p. Dissertação (mestrado) - Escola de Engenharia de São Carlos, Universidade de São Paulo.

33- RIBEIRO, L.F.L. (1990). Utilização de "outriggers" em edifícios altos. Rio de Janeiro. 134p. Dissertação (mestrado) - Universidade Federal do Rio de Janeiro.

34- SAKAMOTO, Y. et al. (1992). Tests of fire-resistant bolts and joints. Journal of Structural Engineering, ASCE, v.119, n.11, p.3131-3150, November. 
35- SALMON, C.G.; JOHNSON, J.E. (1990). Steel structures: design and behavior. 3.ed. New York, Harper \& Row.

36- SIBAI, W.A.; FREY, F. (1993). New semi-rigid joint elements for non-linear analysis of flexibly connected frames. Journal of Constructional Steel Research, v.25, p.185-199.

37- SIMIU, E.; SCANLAN, R.H. (1986). Wind effects on structures. New York, John Wiley \& Sons.

38- TARANATH, B.S. (1988). Structural analysis and design of tall buildings. New York, McGraw-Hill.

39- TIMOSHENKO, S.P.; GERE, J.M. (1961). Theory of elastic stability. Tokyo, McGraw-Hill.

40- TSCHEMMERNEGG, F.; HUMER, C. (1988). The design of structural steel frames under consideration of the nonlinear behaviour of joints. Journal of Constructional Steel Research, v.11, p.73-103.

41- WARBURTON, B.G. (1976). The dynamical behaviour of structures. Oxford, Pergamon Press.

42- ZIGNOLLI, V. (1978). Construcciones metálicas. Madrid, Dossat. 